ANÁLISIS SOCIO JURÍDICO DEL DELITO DE SECUESTRO EN COLOMBIA DESDE 1970: UNA APROXIMACIÓN MULTIDIMENSIONAL

Autor:

CARLOS JAVIER GUTIÉRREZ ROJAS

UNIVERSIDAD SANTO TOMÁS

Maestría en Derecho Penal

Bogotá D.C., Colombia

2018 


\title{
ANÁLISIS SOCIO JURÍDICO DEL DELITO DE SECUESTRO EN COLOMBIA DESDE 1970: UNA APROXIMACIÓN MULTIDIMENSIONAL
}

Trabajo De Grado Como Requisito Para Optar El Título De Magister en Derecho Penal

\author{
Autor: \\ CARLOS JAVIER GUTIÉRREZ ROJAS \\ Especialista en Derecho Procesal Penal y Justicia Penal Militar
}

Tutor:

NICOLAS SANTAMARÍA URIBE

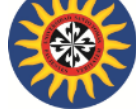

UNIVERSIDAD SANTO TOMÁS

Maestría en Derecho Penal

Bogotá D.C, Colombia

2018 


\section{Contenido}

Pág.

$\begin{array}{lr}\text { INTRODUCCIÓN } & 13\end{array}$

$\begin{array}{ll}\text { Capitulo I. Aproximación Histórica del Secuestro } & 16\end{array}$

$\begin{array}{ll}1.1 \text { Reseña histórica del delito de secuestro } & 16\end{array}$

$\begin{array}{ll}\text { 1.2 El secuestro regulado en la Legislación Romana } & 17\end{array}$

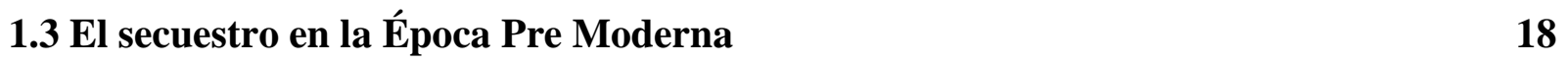

1.4 El secuestro en la Época Moderna 19

$\begin{array}{lr}1.5 \text { El secuestro en la actualidad } & 20\end{array}$

Capítulo II. Definición de secuestro

$\begin{array}{ll}2.1 \text { Etimológica } & 31\end{array}$

2.2 Legal 32

2.2.1 Colombia $\quad 32$

2.2.2 Países referentes para nuestra legislación Penal 38

$\begin{array}{ll}\text { 2.2.2.1 España } & 38\end{array}$

2.2.2.2 Italia $\quad 39$

$\begin{array}{ll}\text { 2.2.2.3 Alemania } & 40\end{array}$

2.2.2.4 Puerto Rico $\quad 40$

2.2.2.5 Chile 42

2.2.2.6 Países Latinoamericanos afectados mayormente con el fenómeno del secuestro 43 
2.2.2.8 Venezuela

2.2.2.9 Brasil 46

$\begin{array}{ll}\text { 2.2.2.10 Guatemala } & 48\end{array}$

$\begin{array}{ll}2.3 \\ \text { Jurisprudencial } & 49\end{array}$

2.3.1 Secuestro simple y secuestro extorsivo 49

2.3.2 Sobre la licitud de la exigencia en el secuestro $\quad 50$

$\begin{array}{ll}\text { 2.3.3 Secuestro por los padres } & 51\end{array}$

2.3.4 Secuestro en el paseo millonario

2.3.5 Secuestro de aeronaves, naves o medios de transporte colectivo 54

2.3.6 Secuestro y trata de personas

2.3.7 Secuestro Como Medio De Guerra 56

$\begin{array}{ll}2.4 \text { Doctrinal } & 57\end{array}$

Capítulo III. Definición Dogmática del Delito de Secuestro 62

$\begin{array}{ll}\text { 3.1 Tipo Objetivo } & 62\end{array}$

$\begin{array}{ll}3.1 .1 \text { Sujetos } & 63\end{array}$

3.1.1.1 Activo $\quad 63$

$\begin{array}{ll}\text { 3.1.1.2 Sujeto pasivo } & 63\end{array}$

$\begin{array}{ll}\text { 3.1.2 Bien Jurídico } & 65\end{array}$

$\begin{array}{ll}3.1 .3 \text { Acción } & 67\end{array}$

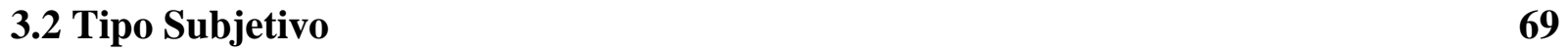

$\begin{array}{ll}\text { 3.3 Antijuridicidad } & 69\end{array}$

$\begin{array}{ll}\text { 3.4 Culpabilidad } & \mathbf{7 0}\end{array}$

3.5 Formas de Ejecución y Consumación $\quad 72$ 
$\begin{array}{ll}\text { 3.6 Tipos Privilegiados } & 74\end{array}$

$\begin{array}{ll}\text { 3.7 Tipos Cualificados } & 74\end{array}$

$\begin{array}{ll}\text { 3.8 Punibilidad } & 76\end{array}$

$\begin{array}{ll}\text { 3.9 Subrogados Y Beneficios } & 77\end{array}$

Capítulo IV. Reseña histórica del secuestro en Colombia

$\begin{array}{ll}\text { 4.1 Características del secuestro y principales actores } & 81\end{array}$

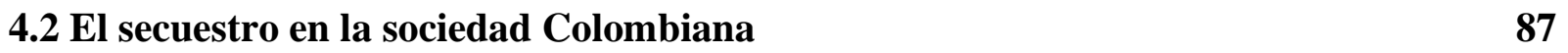

$\begin{array}{ll}4.3 \text { Vestigios del secuestro } & 92\end{array}$

4.3.1 Secuelas psicológicas de la víctima. $\quad 92$

4.3.2 Afectación a la familia y entorno de la victima 96

4.3.3 El Secuestro: Un Trauma Psicosocial 99

$\begin{array}{ll}\text { 4.3.4 Algunos casos relevantes. } & 105\end{array}$

Capítulo V. Legislación Expedida Sobre Secuestro en Colombia 113

$\begin{array}{ll}\text { 5.1 Código Penal de } 1936 & 113\end{array}$

5.2 Código Penal De $1980 \quad 114$

5.3 Decreto 180 de 1988 ó Estatuto Antiterrorista 115

5.4 Decreto 2790 De $1990 \quad 118$

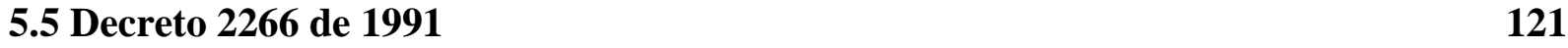

5.6 Ley 40 de 1993 ó Estatuto Antisecuestro $\quad 123$

$\begin{array}{ll}5.7 \text { Ley } 282 \text { de Junio de } 1996 & 128\end{array}$

5.8 Ley 599 de $2000 \quad 129$

5.9 Ley 733 de $2002 \quad 131$

$\begin{array}{ll}\text { 5.10 Ley } 1121 \text { de } 2006 & 134\end{array}$ 
5.11 Ley 1200 de 2008

5.12 Medidas de protección a víctimas de secuestro y sus familias

5.12.1 Ley 986 de 2005.

5.12.2 Ley 1436 de 2011.

5.12.3 Acuerdo 124 de 2004.

Capítulo VI. Modalidades de Secuestro en Colombia 1970-2010

6.1 Motivación Política del Secuestro

6.2 Secuestro extorsivo periodo 1996-2003

6.3 Pescas Milagrosas

Capítulo VII. Análisis Cualitativo de la Información Empírica Existente Sobre Secuestro en

\section{Colombia}

7.1 Ley 40 de 1993

7.2 Ley 599 de 2000 código penal actual

7.3 Ley 733 de 2002

7.4 Ley 1121 de 2006

7.5 Otras causas que influyeron en la disminución del delito de secuestro en Colombia

7.5.1 Desmovilización de grupos paramilitares o autodefensa

7.5.2 ¿Las FARC Dejaron de Secuestrar?

7.5.3 Disminución en las Estadísticas de Secuestros del Eln

7.5.4 Utilización de otras formas de financiación por las guerrillas 
$\begin{array}{ll}\text { 8.2 El "Ser" del poder punitivo en Colombia } & 204\end{array}$

$\begin{array}{ll}\text { 8.3 Las penas en algunos países } & 207\end{array}$

8.4 Reformas al Código Penal en Colombia $\quad 209$

8.5 Incremento punitivo como estrategia para combatir el secuestro en Colombia: ¿paso

hacia la eficacia o populismo punitivo? $\quad 212$

$\begin{array}{ll}\text { 8.6 Política Criminal Del Estado Colombiano } & 218\end{array}$

8.7. Análisis Criminológico Y Política Criminal 225

$\begin{array}{ll}\text { 9. Conclusiones } & 237\end{array}$

10. Referencias Bibliográficas 245 


\section{Lista de Figuras}

Pág.

Figura 1.Informe Pax Christi Internacional 26

Figura 2.Informe empresa global de consultoria Control Risks 26

Figura 3.Informe empresa global de consultoria Control Risks 28

Figura 4.Marcha por el país que queremos. No al secuestro. 91

Figura 5.Mandato ciudadano por la Paz, la Vida y la Liberta 91

$\begin{array}{ll}\text { Figura 6.Marcha movimiento NO MAS } & 91\end{array}$

Figura 7.Un millón de voces contra las FARC también llamada la marcha del 4 de febrero 92

Figura 8.FARC campos de concentración $\quad 183$

Figura 9.El secuestro en Colombia $\quad 184$

Figura 10.Soldados en campos de concentración de FARC 184

Figura 11.FARC anuncian que abandonan el secuestro extorsivo; liberarán 10 uniformados 186 


\section{Lista de Cuadros}

Pág.

Cuadro 1.Actividades y manifestaciones públicas por el secuestro 


\section{Lista de Gráficas}

Pág.

Gráfica 1.Incidencia delictiva - secuestro a algún integrante del hogar 25

Gráfica 2.Participación de los actores del secuestro 86

Gráfica 3.Secuestros 1970 - 2010

Gráfica 4.Secuestro Prisioneros de Guerra 144

Gráfica 5.Número total de secuestros extorsivos a nivel nacional 1996-2003 154

Gráfica 6.Evolución de la participación del total de secuestros extorsivos según autor 1996-2003

Gráfica 7.Secuestros 1996-2003 156

Gráfica 8.Secuestros atribuidos a grupos ilegales 158

Gráfica 9.Retenciones ilegales o “pescas milagrosas” 1998-2002 161

Gráfica 10.Retenciones ilegales o “pescas milagrosas” 1998-2002 - Departamentos 163

Gráfica 11.Evolución delito del secuestro año 1996 al 2015

Gráfica 12.Casos secuestro 1992-1995 170

Gráfica 13.Efectos de la ley 40 de 1993 sobre secuestro $\quad 171$

Gráfica 14.Efecto de la ley 40 de 1993 sobre secuestro $\quad 171$

Gráfica 15.Casos secuestro 1998-2005 174

Gráfica 16.Efectos leyes 599 de 2000 y 733 en temas de secuestro 175

Gráfica 17.Evolución delito del secuestro año 1996 al 2015

Gráfica 19.Efectos expedición ley 1121 de 2006 
Gráfica 20.Efectos expedición ley 1121 de 2006

Gráfica 21.Distribución de la violencia no letal paramilitar y7o GAPD en

Colombia.Discriminado por modalidades antes y después de la desmovilización de 2006

Gráfica 22.Secuestros FARC 1970 -1999

Gráfica 23.Secuestros FARC años 2000 motivo argumentado

Gráfica 24.Secuestros ELN 1970-1999

Gráfica 25.Secuestros ELN años 2000-2010

Gráfica 26.Estadística de secuestro en Colombia 2010-2014

Gráfica 27.Estadística de secuestro en Colombia

Gráfica 28. Comparación de penas máximas en algunos países

Gráfica 29.Desenlace secuestros 1970-2010

Gráfica 30.Exigencias secuestros 1970-2010

Gráfica 31.Tasa de denuncia por ciudad 


\section{Lista de Tablas}

Pág.

Tabla 1.Penas Actuales - Aumentos reseñados

Tabla 2.Leyes ordinarias que modifican la parte especial del Código Penal 


\section{INTRODUCCIÓN}

El objetivo del presente trabajo es realizar un análisis socio jurídico del delito de secuestro en el Código Penal Colombiano desde una perspectiva que abarca elementos conceptuales, dogmáticos, políticos y político criminales. En otras palabras, ofrece una mirada multidimensional al fenómeno. La elección del tema radica en varios motivos de orden empírico, teórico y metodológico, a saber: la relación entre el delito y los procesos socio políticos del país, la notable variación en la ocurrencia del mismo en las últimas décadas, la ausencia de un estudio riguroso y amplio que aborde el fenómeno desde las herramientas propias del derecho penal, la necesidad de entender el impacto de la política criminal sobre la ocurrencia del secuestro y, finalmente, el interés por analizar el mismo fenómeno desde herramientas teóricas y conceptuales de diversas disciplinas.

En la década de los 90 y a comienzos de la siguiente década, el secuestro se convirtió en una de las formas más rentables de financiación para los grupos armados al margen de la ley, principalmente para las guerrillas. Por otra parte, en la década de los 90 los carteles de narcotraficantes utilizaron el secuestro de personas representativas en la sociedad como mecanismo de presión al gobierno de turno para la no extradición.

Para el año 2000, Colombia ocupaba el primer lugar entre los países con mayor número de casos de secuestro en el mundo, con un promedio de 8 casos por día; en el mismo sentido en las estadísticas reveladas por el informe ;Basta Ya! del Centro Nacional de Memoria Histórica se puede observar que entre 1970 y 2010, fueron secuestradas 39.058 personas. De esta publicación, igualmente se puede extraer que 
Análisis Socio Jurídico del delito de secuestro en Colombia a partir de 1970

este delito ha afectado la totalidad de los departamentos del país y que el principal

autor de los casos confirmados fue las FARC, con en el 37\% de los ilícitos. (Centro

Nacional de Memoria Histórica, 2013, Pág., 28)

Surge entonces la necesidad de confirmar o desvirtuar varias hipótesis en este trabajo, todas ellas tendientes a identificar cual ha sido el impacto de la expedición de legislación en materia de secuestro en Colombia, así como determinar su eficacia con respecto a los propósitos de prevención y erradicación del mismo. Del mismo modo, se pretenderá corroborar o desvirtuar, la hipótesis consistente en que la disminución del secuestro en Colombia, obedece tanto a la creación de legislación como a factores socio políticos presentes en las últimas décadas y, a la luz de este objetivo, señalar puntualmente dichas causas.

El estudio tiene un corte empírico y para la comprobación de las hipótesis planteadas se combinarán métodos cuantitativos (estadísticas descriptivas principalmente) y se utilizará una compilación y un análisis de legislación que se ha producido por parte del Congreso Nacional de Colombia, incluyendo, dentro de ella, las exposiciones de motivos que llevaron a la expedición de esas normas y los debates que tuvieron lugar en el Legislativo. En el mismo sentido, se analizará el contexto socio político en que se produjo la legislación en materia de secuestro en Colombia, confrontándola con las bases de datos existentes que contienen cifras sobre el punible, ello para establecer el impacto del contexto sobre el fenómeno analizado.

A la luz de este propósito, las nociones de comprensión forzosas en esta disertación son: la reseña histórica del delito de secuestro, la definición del concepto del secuestro y sus características, el impacto de la Legislación Colombiana sobre el fenómeno del secuestro, y el análisis de la información empírica existente sobre el secuestro en Colombia. 
Análisis Socio Jurídico del delito de secuestro en Colombia a partir de 1970

Así las cosas, esta disertación se desarrolla en tres partes. En la primera, se enfatizará -en consonancia con lo descrito por la Honorable Corte Constitucional, que la sociedad Colombiana a lo largo de décadas viene sufriendo esta forma de criminalidad, como uno de los delitos que mayor afectación social tiene. En efecto, el secuestro genera no sólo en la victima y sus familias, sino en la sociedad un fuerte impacto psíquico y moral. Mientras en la segunda se aborda el análisis dogmático del ilícito estudiado, buscando precisar el concepto del delito de secuestro , así como la legislación expedida, para que una vez identificada la legislación expedida por el Congreso Nacional tendiente a la erradicación del delito de Secuestro en Colombia, realizar un estudio sobre la eficacia de estas disposiciones, confrontando las estadísticas y bases de datos de acceso público como lo son el Centro Nacional De Memoria Histórica, Verdad Abierta, Policía Nacional, entre otras.

La conclusión a la que este documento llega, tiene que ver con explicar de manera empírica cuál ha sido la influencia de estas normas elaboradas sobre este fenómeno delictivo, analizando si en los lapsos en que se han expedido estas normas, la ocurrencia de este fenómeno ha disminuido o por el contrario ha tenido efectos diferentes. 
Análisis Socio Jurídico del delito de secuestro en Colombia a partir de 1970

\section{Capitulo I. Aproximación Histórica del Secuestro}

Con el fin de precisar qué es y en qué consiste el delito de secuestro es conveniente hacer una breve reseña histórica, de carácter exclusivamente descriptivo, que permita al lector conocer algunas piedras angulares de la historia de este delito.

\subsection{Reseña histórica del delito de secuestro}

El secuestro es una actividad cuyo inicio se remonta al momento que el hombre se agrupó para la caza. Existen viejas referencias de él tanto en la Biblia como en el Corán, donde se le conoció como plagio. En sus inicios el secuestro tuvo varios fines, a saber: conseguir mujeres, derrocar al líder de una población, ganar dinero o como premio de guerra. Generalmente se castigaba al responsable con la muerte. (Clutterbuck, 1979)

Posteriormente, el secuestro fue limitando sus fines a botín de guerra, de tal suerte que se sustituyó la práctica de matar a los soldados capturados en batalla, por el cambio de ellos cobrando un rescate por su liberación, lo fue llamado litrum incendiarium. (Callamand, 1988, Pág., 59).

Uno de los primeros secuestros documentados fue en Roma en el año 78 A.C. cuando Caius Julius César viajaba en un barco mercante a la isla de Rodhas siendo privado de su libertad por piratas quienes pidieron un rescate de 20 "talentos", lo que según la anécdota molestó a César quien pensaba valer más, al menos 50. Después de pagar el 
Análisis Socio Jurídico del delito de secuestro en Colombia a partir de 1970

rescate y haber sido liberado, César persiguió a los autores, capturando a 350 piratas y recuperó el dinero del botín. (Martiñón, 2008, Pág., 31)

\subsection{El secuestro regulado en la Legislación Romana}

Al paso del tiempo, en el auge romano, el secuestro se conceptualizó como "crimen plagium" o sencillamente plagio, que deriva de la voz latina piaga, plaga que significa calamidad. (Martiñón, 2008, Pág., 31)

En aquel tiempo, el plagio era sancionado por la ley militar y abarca tres formas: una como el apoderamiento de un hombre libre, generalmente prisionero de guerra; otra fue la retención y aprehensión de un esclavo con los perjuicios para su dueño; y la tercera modalidad, consistió en el llamado "crimen vis" versante esencialmente en la violencia física o moral utilizada contra una persona para obligarla a ejecutar u omitir una acción. (Callamand, 1988, Pág., 58)

Luego, después de Cristo, también en Roma, se definió el plagio como: "El huerto de hijos o siervos ajenos para servirse de ellos o venderlos como esclavos" (Lozano, 1968, Pág., 974); dándole a los rehenes, el mismo trato que a las cosas pues la pérdida de los siervos fue considerada un afectación patrimonial.

En la misma Roma, pero en la llamada "Época de los prácticos", se reformuló la clasificación sobre plagio en otros tres tipos: Político o Militar, que consistió en alistamiento forzoso de un súbdito, al ejército. Y Civil, cuando un particular privaba de la libertad a un apersona por medio de violencia o engaño con el único propósito de exigir rescate por su libertad. Y el literario, en el que se especulaba sobre una ganancia sobre una obra ajena, en perjuicio del verdadero autor. 
Análisis Socio Jurídico del delito de secuestro en Colombia a partir de 1970

Constituyéndose, el segundo de los mencionados en el párrafo anterior, como un precedente directo, claramente el abuelo, del secuestro de la actualidad. (Díaz de León, 1989, Pág., 1323)

\subsection{El secuestro en la Época Pre Moderna}

En la Edad Media, el secuestro fue usado por la realeza, mayormente por "barones" que habían ido a la quiebra y secuestraban a mujeres, por las que pedían rescate. Con posteridad, Italia registra, informes de la frecuencia de secuestros caracterizados por la privación de la libertad de rehenes en los bosques donde eran llevados a enclaustrar en lugares fortificados hasta que pagaba el rescate.

Fue tan reiterada la comisión de secuestros en Italia que se llegó a conocer como la Meca del referido y deliro como que el Papa Sixto V dictó a principios del año X la llamada "Ley Pica", por la que el secuestro dejó de ser regulado por la ley marcial y pasó al fuero civil en donde continuaron los conceptos de rehén y rescate. Al respecto el tratadista Francesco Carrara (1996), señalaba:

Lo que le da colorido especial de maldad a este hecho es la formación de bandas, puestas en lucha abierta con la autoridad que amenazaban al gobierno mismo. Pero en este caso ya no nos hallaremos dentro de los términos del mero robo con rescate, sino de una verdadera guerra civil y muy sangrienta, cuyo remedio no debe esperarse del derecho penal, sino de los cañones y los principios del Derecho Penal deben reemplazarse por los del derecho de guerra, de una guerra empeñada contra un 
Análisis Socio Jurídico del delito de secuestro en Colombia a partir de 1970

enemigo feroz e injusto, que al negar cuartel no tiene motivo para esperarlo (...) (Pág., 178)

Ya en la Ley Civil, el secuestro se diferenció del plagio, pues el secuestro fue para los hombres libres mientras el plagio era para los esclavos. En aquellos ayeres, tanto el secuestro como el plagio eran regulados como afectaciones patrimoniales y castigadas con severísimas sanciones generalmente con la muerte del responsable.

El secuestro se dio prácticamente en todo el mundo, en un principio con diversas particularidades de acuerdo a la región en que se cometían, como los cometidos en Andalucía, donde se conocieron bandas que operaban y dirigían el delito desde su casa. (Martiñón, 2008, Pág., 33)

\subsection{El secuestro en la Época Moderna}

El siglo XVII (1678), surge el vocablo inglés: Kidnapping con el cual se denomina "el robo de infantes". "Esta práctica tiene antecedente en el apoderamiento de niños por parte de algunas bandas organizadas de Inglaterra, los cuales eran luego vendidos en Norteamérica, donde se requería mano de obra barata" (Martiñón, 2008, Pág., 33)

Posteriormente, en 1853, el Derecho Penal Ingles estableció la sanción de la "servitude", por la que se reguló legalmente la práctica de canjear un prisionero de guerra por dinero.

Con dichos precedentes llegó el secuestro al siglo XX, donde en sus principios, con la abolición de la esclavitud, mutó la voz plagio por otra latina: "sequestrate” abriéndose, 
Análisis Socio Jurídico del delito de secuestro en Colombia a partir de 1970

una nueva etapa en su historia asumiendo el sitio propio e indiscutible de los delitos que atentan contra la libertad. (Callamand, 1988, Pág., 52)

Entonces, el secuestro no es particular de una región, ni de un tiempo determinado. En la actualidad, a principios del siglo XXI, continúa acreditándose tanto con diversos fines como con distinto tratamiento punitivo, podemos inferir que uno de los factores que incrementa el número de secuestros es una relación costo-beneficio. Es decir si es fácil cometerlos y altos los dividendos, el delito en mención se incrementa; y viceversa, si es difícil cometerlo y bajos los dividendos, el delito decrece.

Ahora, las condiciones de costo-beneficio obedecen a múltiples factores entre otros: corrupción, la impunidad de los secuestradores, la ineficiencia de los órganos de justicia, entre otros. Sobre los motivos para perpetrar los secuestros podemos decir que son varios, pueden ser desde obtener un rescate, causar un daño (sea este físico o mental) o adquirir un favor político. (Órnelas, 2002, Pág., 16)

\subsection{El secuestro en la actualidad}

A nivel mundial, las asociaciones de Estados han propendido por la creación de instrumentos eficaces para velar de manera efectiva por la garantía de los derechos humanos, luchando además contra el desconocimiento y el menosprecio de los derechos humanos, lo cual ha originado actos de barbarie ultrajantes para la conciencia de la humanidad, esto aparece consignado expresamente en la DECLARACIÓN UNIVERSAL DE DERECHOS HUMANOS adoptada y proclamada por la Asamblea General de las Naciones Unidas mediante resolución 217 A expedida el 10 de diciembre de 1948. 
Análisis Socio Jurídico del delito de secuestro en Colombia a partir de 1970

Sobre el secuestro como arma de guerra, podemos evidenciar que la Organización de las Naciones Unidas para el año de 1949 (12 de agosto) decidió la creación e implementación de los convenios de Ginebra, corolario de un trabajo realizado por el Comité Internacional de la Cruz Roja, entidad que desde años anteriores ya había procurado que el derecho de gentes se otorgara a la persona humana con el fin de brindarle una mejor defensa contra las calamidades de la guerra. En consecuencia, en el período transcurrido entre las dos guerras mundiales, se elaboraron proyectos de Convenios y especialmente del Convenio relativo al trato debido a los prisioneros de guerra, el cual fue firmado en 1929, y se convirtió en la salvaguardia de millones de cautivos o prisioneros de guerra. En consecuencia, se advierte que en caso de conflicto armado que no sea de índole internacional, cada una de las partes en conflicto tendrá la obligación de aplicar disposiciones entre ellas la de la prohibición de la toma de rehenes. Por ende a la luz de estos convenios, en nuestro caso, principalmente - a las guerrillas, se les impone esta obligación de no secuestrar tanto civiles como miembros de la fuerza pública y ante la negativa de liberación unilateral, surge para el Estado la obligación de garantizar vida y libertad de sus ciudadanos, encontrar alternativas y mecanismos viables para conseguir la libertad de los secuestrados. (Comité Internacional de la Cruz Roja, 2012, Pág., 38)

Citando a Heyck Puyana en su artículo "El Acuerdo Humanitario Y el Rescate Militar de los Secuestrados Políticos a la Luz del Derecho Internacional Humanitario- DIH”, el secuestro de civiles constituye un crimen de guerra prohibido por el Artículo 3 Común a los Convenios de Ginebra de 1949, así como también una violación al artículo 7 de la Convención Americana de 
Análisis Socio Jurídico del delito de secuestro en Colombia a partir de 1970

Derechos Humanos y a nivel interno, el secuestro también constituye una infracción al Código Penal Colombiano. En relación con la situación de los miembros de la Fuerza Pública, la prolongada retención, las condiciones que padecen y la incomunicación de los cautivos también implica una violación de la normatividad internacional en materia de derechos humanos y de conflictos internos.

Sobre el tema de menores de edad, para el año de 1980, los Estados signatarios del Convenio de la Haya, otorgando gran importancia a los intereses del menor en temas relativos a su custodia, y con la finalidad de protegerlos en el plano internacional, de los efectos perjudiciales que podría ocasionarle un traslado o una retención ilícitos, deciden el 25 de octubre del citado año firmar el Convenio sobre los Aspectos Civiles de la Sustracción Internacional de Menores; buscando además garantizar la restitución inmediata de los menores trasladados o retenidos de manera ilícita en cualquier Estado contratante y velar por que los derechos de custodia y de visita vigentes en uno de los Estados contratantes se respeten en los demás Estados contratantes.

Avanzando en el tiempo se encuentra que la citada Asamblea de Naciones Unidas, para el año 2004 preocupada por el aumento de la práctica del secuestro en varios países del mundo y por los efectos perjudiciales que este delito produce en las víctimas y sus familias, reitera que el secuestro de personas, en cualquier circunstancia e independientemente de su propósito, constituye un delito grave y una violación de la libertad individual que menoscaba los derechos humanos. Es así como, a través de la Resolución No 59/154 expedida el 20 de diciembre del año en cita, la Asamblea General Condena enérgicamente y rechaza una vez más la práctica del secuestro, en cualquier circunstancia e independientemente de su propósito, especialmente cuando sea realizada por grupos delictivos organizados y grupos terroristas. 
Análisis Socio Jurídico del delito de secuestro en Colombia a partir de 1970

Para el año 2006, en desarrollo de lo planteado en la resolución 59/154 de la Asamblea General, la Oficina de las Naciones Unidas contra la Droga y el Delito elaboró el Manual de lucha contra el secuestro, dentro del cual se incluyen prácticas comprobadas y prometedoras que las autoridades competentes pueden utilizar para combatir este fenómeno. La motivación que aduce esta oficina para la expedición de esta manual, tiene que ver con el crecimiento del problema del secuestro a nivel mundial, además que esta violación de la libertad individual afecta de manera horrorosa a la víctima como a sus familiares, los amigos íntimos y los colegas, al mismo tiempo que crea temores y dudas en las comunidades y puede tener consecuencias adversas para la economía y la seguridad de los Estados.

En este momento se sigue utilizando el secuestro como arma de presión política, son varias las modalidades de secuestro que se emplean en el mundo y que afectan a diferentes sectores de la sociedad, a continuación se exponen algunos de los casos más representativos:

El informe de Desarrollo Humano de ONU correspondiente a 2014 advirtió "la creciente presencia de redes de narcotráfico y criminalidad organizada, lo que requiere que los gobiernos deben fortalecer la presencia policial" (Programa de Naciones Unidas para el Desarrollo, 2014, Pág., 4).

Según reportes de prensa, en la región latinoamericana, México es el país de la región con mayor índice de secuestros. Entre enero y marzo, en distintas ciudades mexicanas, se produjeron 340 casos, para el año 2013 en México hubo 2.663 secuestros, Venezuela es el segundo país de la región y quinto en el mundo en materia de secuestros comparándolo con México para 2013, hubo un total de 382 casos y en el primer semestre de 2014 tuvieron lugar 110 secuestros. En Argentina la tasa de secuestros en ese país es de 0,5 cada 100 mil habitantes. (El Observador, 2015, p. 1) 
Análisis Socio Jurídico del delito de secuestro en Colombia a partir de 1970

A nivel global, la organización humanitaria holandesa IKV Pax Christi, revela que la cifra de secuestros a nivel global oscila entre 40.000 y 100.000 casos al año, destacando los casos de México, Colombia, Venezuela y Ecuador. Latinoamérica se ubica en primer lugar en materia de este tipo de delitos, sobre todo por la alta prevalencia de casos que desde hace varios años existe en México. (Pax en Colombia, 2016)

- "Para el cierre de 2015 un total de 54 periodistas permanecían secuestrados según el informe anual de Reporteros Sin Fronteras (RSF) que expone las claves de un año marcado por la "barbarie" del yihadismo" (Infolibre, 2016, Párr., 1).

- "Entre los años 2006 y 2016 se han presentado por lo menos 12 casos de secuestros aéreos todos ellos con motivaciones políticas" (El Mundo, 2016, Párr., 2).

- Desde comienzo de 2014, el grupo terrorista islamista Boko Haram ha secuestrado al menos a dos mil mujeres y niñas en Nigeria desde principios de 2014, divulgó la organización humanitaria Amnistía Internacional (AI). Siendo uno de los casos más sonados, el secuestro de 276 escolares en Chibok (Nigeria). (20 minutos, 2016, Párr., 1)

En México, del cual se dice que es uno de los países del continente con más índices de secuestro en la actualidad, las últimas cifras publicadas apuntan hacia unos 1.500 casos en 2015, basados en denuncias formalizadas ante algún ente de seguridad estatal. No obstante, de acuerdo al Instituto Nacional de Estadísticas y Geografía (INEGI), la verdadera cifra de secuestros podría ascender a 100.000 al año, según un estudio basado en encuestas del hogar en 2014. Es así como este ente, encontró en sus sondeos que apenas 1\% de los casos son denunciados formalmente ante las autoridades, lo cual de hecho coincide con las cifras oficiales. (Instituto Nacional de Estadística y geografía, 2012, Pág., 1)

Lo anterior, se puede apreciar en el siguiente gráfico: 
Análisis Socio Jurídico del delito de secuestro en Colombia a partir de 1970

Gráfica 1. Incidencia delictiva - secuestro a algún integrante del hogar

La ENVIPE estima a nivel nacional 102,883 secuestros a algún integrante del hogar sufridos por 99,747 víctimas durante 2014.

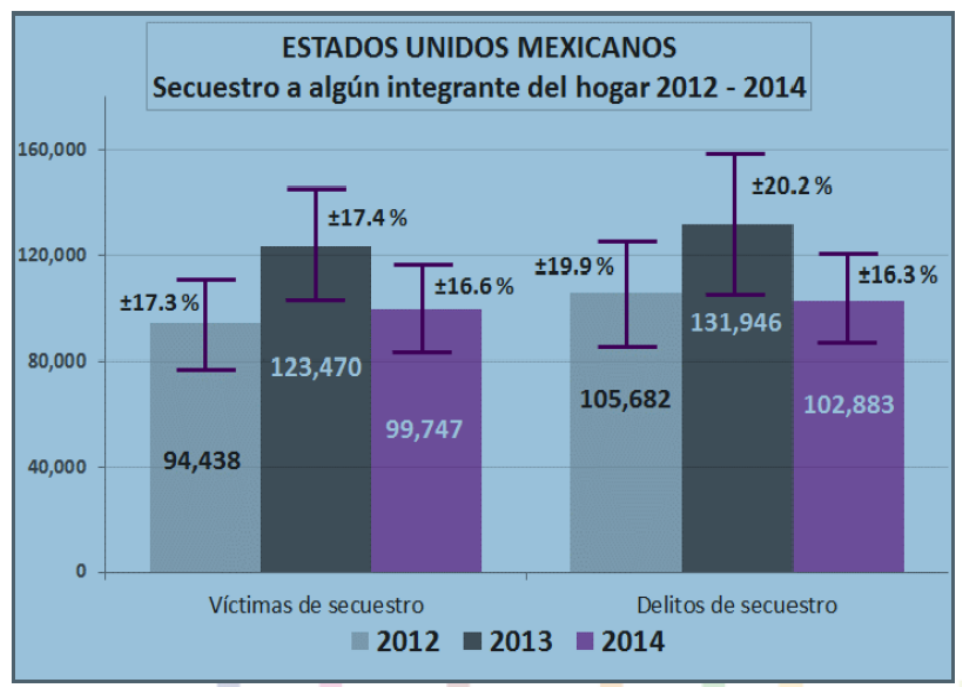

\begin{tabular}{|c|c|c|c|}
\hline \multirow{2}{*}{ Secuestros } & \multicolumn{3}{|c|}{ Tasas $\mathrm{p} / \mathrm{c} 100,000$ habs. $^{/ \mathrm{a}}$} \\
\hline & 2012 & 2013 & 2014 \\
\hline $\begin{array}{l}\text { Víctimas } \\
\text { (Prevalencia) }\end{array}$ & 80 & 103 & 83 \\
\hline $\begin{array}{l}\text { Delitos } \\
\text { (Incidencia) }\end{array}$ & 89 & 110 & 85 \\
\hline \multicolumn{4}{|c|}{$\begin{array}{l}\text { la La tasa p/c 100,000 habitantes presentada en este tabulado se } \\
\text { construye a partir de un universo de } 120,738,843 \text { habitantes. }\end{array}$} \\
\hline $\begin{array}{l}\text { Duración de } \\
\text { los Secuestros }\end{array}$ & $\begin{array}{c}2012 \\
(\%)\end{array}$ & $\begin{array}{c}2013 \\
(\%)\end{array}$ & $\begin{array}{c}2014 \\
(\%)\end{array}$ \\
\hline $\begin{array}{l}\text { Menos de } 24 \\
\text { horas }\end{array}$ & 57.0 & 64.8 & 59.8 \\
\hline De 1 a 3 días & $18.9^{/ b}$ & 17.4 & 23.2 \\
\hline 4 días o más & $18.6^{/ b}$ & 13.2 & 14.8 \\
\hline No especificado & $5.5^{/ b}$ & $4.6^{/ b}$ & $2.2^{/ \mathrm{b}}$ \\
\hline
\end{tabular}

Fuente: Encuesta Nacional de Victimización -ENVIPE, 2015

A nivel mundial, sobre el tema de secuestro se han realizado por parte de organizaciones no gubernamentales y/o empresas globales de consultoría, estudios de riesgo han concluido que para el año 2016 algunos países de Centro américa (México), Suramérica (Colombia, Brasil, Venezuela), Asia (Pakistán, Filipinas, India) y África (Nigeria, Burkina Faso, Libia, Egipto), son los más proclives a que se cometa en su territorio esta clase de hechos. 
- Informe Pax Christi International:

Figura 1. Informe Pax Christi Internacional

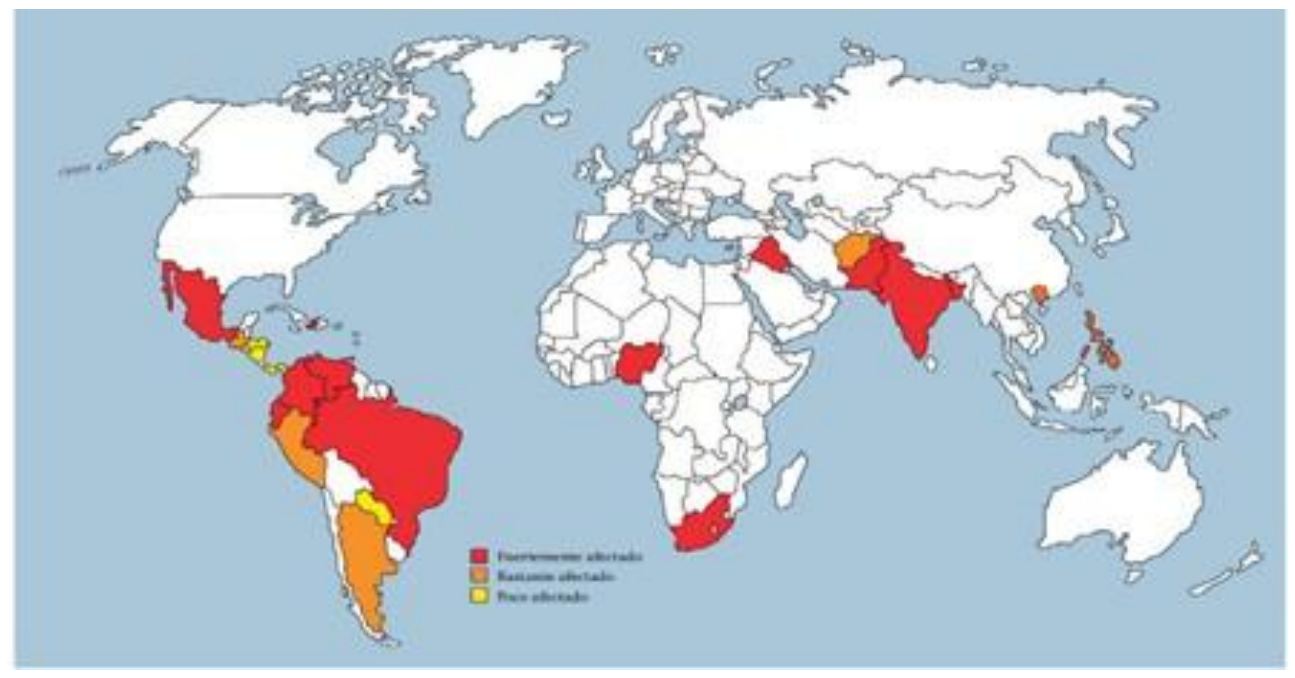

Fuente: IKV PAX, 2016

- Informe empresa global de consultoría Control Risks:

Figura 2. Informe empresa global de consultoria Control Risks

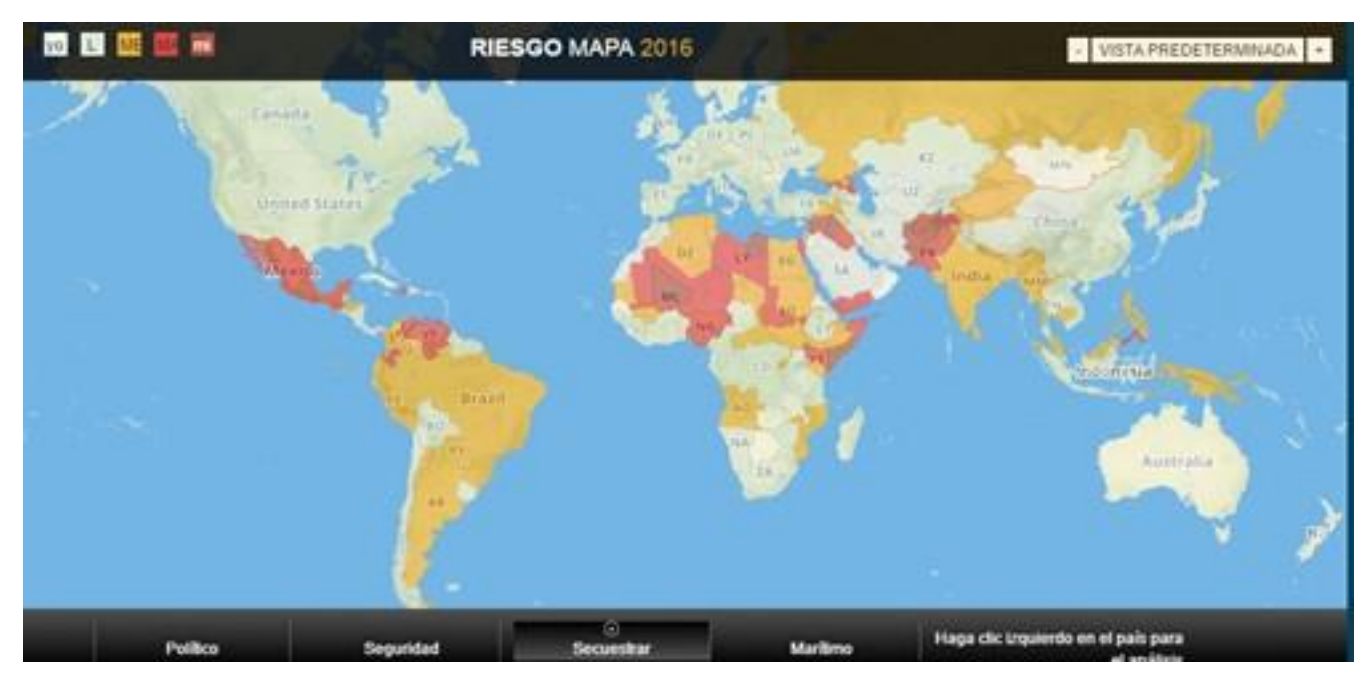

Fuente: Riskmap, 2016 
Análisis Socio Jurídico del delito de secuestro en Colombia a partir de 1970

Según el último reporte de Control Risks, una organización independiente dedicada a calcular el nivel de riesgo en los países del Mundo, en el año 2013 Latinoamérica fue el tercer continente con mayor cantidad de secuestros, pero con México a la cabeza en la lista como el país con la mayor cantidad de secuestros de todo el planeta.

Asia fue el continente con la mayor cantidad de secuestros en 2013, alcanzando el $35 \%$ de los secuestros mundiales. Le sigue África con el 25\% de los secuestros anuales y, como se dijo anteriormente, Latinoamérica con el 22\%. Europa, Canadá y Estados Unidos no llegan al 2\%. (Prodavinci, 2013, Pág., 1)

En 1990, el ex oficial del Ejército de los Estados Unidos de América Neil M Young, funda la empresa NYA, especialista en la prevención de crisis y análisis de riesgo, la cual rinde un informe a nivel global sobre el fenómeno del secuestro en 2014, según esta empresa de consultoría el informe basado en incidentes de secuestro por rescate registrados en los informes de noticias de código abierto y capturado hasta finales de diciembre de dicho año y la información, se basa en código abierto, pretendiendo poner de manifiesto las noticias actuales, tendencias y análisis de incidentes de secuestro para rescates a nivel mundial durante el período de referencia. Veamos el resultado: 
Figura 3. Informe empresa global de consultoria Control Risks

\section{Kidnap for Ransom Overview}

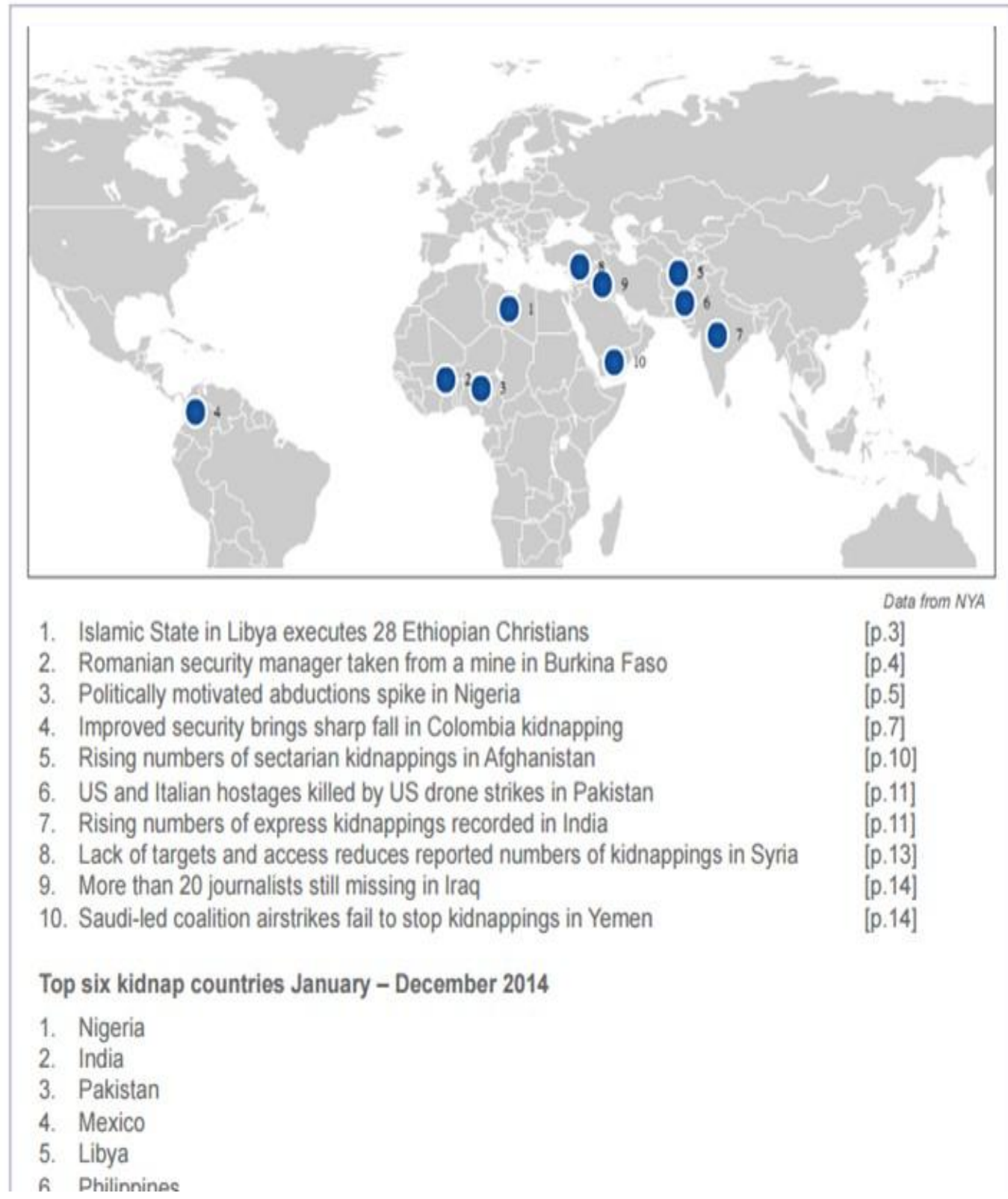

Fuente: NYA, 2015 
Análisis Socio Jurídico del delito de secuestro en Colombia a partir de 1970

De acuerdo con el Observatorio Nacional Ciudadano (ONC), en 2013 México fue el país a nivel mundial que más secuestros registró durante el año, seguido de cerca por la India y Nigeria. En el marco de la presentación del “Análisis integral del secuestro en México: Cómo entender esta problemática”, el ONC también señaló que es América Latina donde se concentra el $23 \%$ de los secuestros a nivel mundial. En este ranking, México encabeza la lista de los países con mayor número de secuestros seguido por Venezuela, Colombia, Guatemala y Brasil. (Observatorio Nacional Ciudadano, 2016)

Debido a la existencia de diferentes modalidades de secuestro, la legislación internacional se ha encargado de considerar estas situaciones a tal punto que el Estatuto de Roma de la Corte Penal Internacional (2002), ha definido el alcance de la conducta de "desaparición forzada de personas" entendiéndola como la aprehensión, la detención o el secuestro de personas por un Estado o una organización política, o con su autorización, apoyo o aquiescencia, seguido de la negativa a admitir tal privación de libertad o dar información sobre la suerte o el paradero de esas personas, con la intención de dejarlas fuera del amparo de la ley por un período prolongado.

Las causas y condiciones por las que se ha venido presentando el fenómeno del secuestro, son reseñadas por el sociólogo Jon Elster (2004), las cuales se pueden concretar así:

En punto a destacar cuales son algunas de las causas, se tiene que la Guerra Fría generó una demanda de secuestros, pues los fondos que proveían de las superpotencias se habían agotado, así se observa que el uso del secuestro repercute en la acumulación de fondos para las organizaciones delictivas. Sobre las condiciones se puede señalar que los secuestros, al igual que las misiones suicidas, se han extendido por contagio e imitación. Para Elster (2004) una condición especialmente favorable, es contar con un terreno escarpado, pues en esas circunstancias es más 
Análisis Socio Jurídico del delito de secuestro en Colombia a partir de 1970

fácil ocultar a las víctimas, sin embargo, los secuestros urbanos en Italia y Beirut también han sido exitosos. También es relevante, la elección entre la toma de rehenes y el secuestro depende del equilibrio percibido entre la publicidad y seguridad. 


\section{Capítulo II. Definición de secuestro}

Una vez expuesta la evolución histórica del delito de secuestro, se considera relevante referir las definiciones dadas al término secuestro desde las perspectivas etimológica, legal, jurisprudencial y doctrinal.

\subsection{Etimológica}

En Diccionarios legales se pueden encontrar definiciones de la palabra secuestro, el diccionario Jurídico Cabanellas, precisa el concepto como:

Un delito mixto contra la libertad individual y la integridad de las personas y, por lo común, contra la propiedad; y a que su objetivo primordial consiste en obtener una suma de dinero, a costa del rescate de una persona del afecto de aquel a quien se le exige la cantidad; cuya negativa conduce, de acuerdo con las amenazas, a la muerte, tortura, ultraje u otro desmán del que será víctima el privado de libertad y situado en lugar secreto. (Diccionario Jurídico Cabanellas, 2016)

En el mismo sentido, la Enciclopedia de la Ley de Duhaime, “da la acción realizada para llevar a alguien fuera de un lugar sin el consentimiento de esa persona, o mediante fraude" (Enciclopedia de la Ley de Duhaime, 2016)

Y el diccionario de Ciencias Jurídicas Políticas y Sociales especifica el alcance del término jurídico secuestro de personas, como: 
Análisis Socio Jurídico del delito de secuestro en Colombia a partir de 1970

La acción de aprehender indebidamente a una persona para exigir dinero por su rescate o para otros fines, agregando que en la Legislación Penal se suele definir ese delito con alcance más limitado que en la definición lingüística, ya que se configura por el hecho de que el secuestro se realice con el propósito, logrado o no, de obtener rescate, y de ahí que se haya incluido entre los delitos contra la propiedad y, dentro de ellos, entre los de extorsión. (Diccionario de Ciencias Jurídicas, Políticas y Sociales, 2016)

\subsection{Legal}

En este punto se distingue que se entiende por secuestro en las legislaciones de diferentes países, iniciando por Colombia y otras naciones cuyos estatutos penales serán traídos para su estudio en la parte pertinente, al considerarse como referentes en razones a que son ascendientes en la evolución del Derecho Penal Colombiano, o como se explicó en el capítulo anterior ser países afectados gravemente por este flagelo.

\subsubsection{Colombia}

En el ordenamiento Penal Colombiano el secuestro y sus diferentes formas de ejecución, se encuentran ubicados en el título III del libro segundo del Código Penal, definiendo como secuestro simple la realización de conductas reprochables tales como: "arrebatar, sustraer, retener u ocultar a una persona" (art 168), como secuestro extorsivo "cuando estas se realizan con el propósito de exigir por su libertad un provecho o cualquier utilidad, o para que se haga u omita algo, o con fines publicitarios o de carácter político” (art 169). 
Análisis Socio Jurídico del delito de secuestro en Colombia a partir de 1970

Como circunstancias de agravación se establecen algunas relacionadas con la persona que realiza el hecho o sobre la cual se comete y otras relacionadas con los fines o las formas como se realiza. Entre las primeras se destacan cuando la conducta se cometa en persona discapacitada que no pueda valerse por sí misma o que padezca enfermedad grave, o menor de dieciocho (18) años, o que no tenga la plena capacidad de autodeterminación, o que sea mujer embarazada, cuando se ejecuta respecto de pariente hasta el cuarto grado de consanguinidad, cuarto de afinidad o primero civil, sobre cónyuge o compañera o compañero permanente, o aprovechando la confianza depositada por la víctima en el autor o en alguno o algunos de los partícipes; cuando la conducta se realice por persona que sea servidor público o que sea o haya sido miembro de las fuerzas de seguridad del Estado; si se comete en persona que sea o haya sido periodista, dirigente comunitario, sindical, político, étnico o religioso en razón de ello o en persona internacionalmente protegida diferente a las señaladas en el título II de éste Libro y agentes diplomáticos, de conformidad con los Tratados y Convenios Internacionales ratificados por Colombia (art 170).

Sobre las circunstancias agravantes relacionadas con los fines o formas como se realiza el secuestro, tenemos la relacionada con el hecho que la privación de la libertad del secuestrado se prolongue por más de quince (15) días; cuando se obtenga la utilidad, provecho o la finalidad perseguidos por los autores o partícipes; cuando se afecten gravemente los bienes o la actividad profesional o económica de la víctima; si se comete en persona que sea o haya sido periodista, dirigente comunitario, sindical, político, étnico o religioso en razón de ello; cuando se trafique con la persona secuestrada durante el tiempo de privación de la libertad (art 170). 
Análisis Socio Jurídico del delito de secuestro en Colombia a partir de 1970

Las circunstancias de atenuación punitiva proceden cuando se dejare voluntariamente en libertad a la víctima dentro de los quince días siguientes al secuestro, sin que se hubiere obtenido alguno de los fines previstos para el secuestro extorsivo, o cuando en el secuestro simple dentro del mismo término, la victima fuere dejada voluntariamente en libertad.

En la Legislación Penal Colombiana, específicamente en la ley 599 de 2000, se han tipificado como delitos autónomos: la esclavitud sexual en persona protegida (art 141A), la trata de personas en persona protegida con fines de explotación sexual (art 141 B), toma de rehenes (art 148), detención ilegal y privación del debido proceso (art 149), desaparición forzada (art 165),apoderamiento y desvío de aeronaves, naves o medios de transporte colectivo (art 173), así como los delitos relacionados con detención arbitraria (capitulo 4). (Legislación Penal Colombiana, 2000, Ley 599)

La incorporación de estos punibles a la legislación Colombiana tiene una relación directa con el conflicto armado que aqueja al país, ya que con la comisión de estos se han violentado bienes jurídicos sujetos de protección no solo por la legislación interna sino por las normas orbitales a través del Derecho internacional Humanitario que tiene como fin la preservación de la dignidad humana durante los conflictos armados.

En este sentido, su normativa procura el respeto de unos derechos mínimos e inderogables que cobijan tanto a combatientes como a no combatientes (de manera diferenciada), y que en términos generales, pretende establecer un equilibrio entre necesidades militares y el principio de humanidad, con el objeto de disminuir las hostilidades, minimizar los efectos sobre la población civil y sus bienes, y garantizar un trato humanitario a combatientes, heridos y prisioneros. (Salmón, 2004) 
Análisis Socio Jurídico del delito de secuestro en Colombia a partir de 1970

Se debe resaltar que las disposiciones que integran el derecho internacional humanitario no tienen carácter de autoejecutivas, lo que implica que para crear derechos y establecer obligaciones aplicables al interior de los Estados e invocables ante sus tribunales, requieren de un desarrollo legislativo en los ordenamientos jurídicos nacionales.

Dando desarrollo a estas preceptivas se incorporan las normas contenidas en el Título II del Libro $2^{\text {o }}$ del Código Penal (Ley 599 de 2000), y en consecuencia se tipifican como delitos en nuestra legislación interna las infracciones graves contra las personas y bienes protegidos por el derecho internacional humanitario, lo que va en consonancia con la normativa humanitaria que obliga a los Estados a adoptar medidas legislativas para establecer sanciones penales adecuadas a sus infractores. Lo anterior para conformar el marco normativo a través del cual las autoridades judiciales pueden investigar y sancionar los crímenes internacionales en el ámbito interno. Por su parte, en virtud del artículo 93 de la Carta Política, el derecho internacional humanitario se erige como fuente de interpretación de los delitos incorporados en dicho título, fundamentalmente a la hora de dar contenido a algunos ingredientes normativos. (Páez, 2010)

En ese tenor, como se dijo, el Título II del Libro $2^{\circ}$ del Código Penal incorporó al derecho interno la sanción de algunas infracciones a la normativa de derecho internacional humanitario vinculante para el Estado colombiano, penalizando diversas conductas cometidas con ocasión y en desarrollo del conflicto armado que atentan contra personas y bienes protegidos por la normativa humanitaria. Dicha norma equipara bajo una misma descripción típica estas dos conductas, definiéndolas como la prestación forzosa de servicios sexuales. Sin embargo, más allá del artículo 141 del Código Penal, no existe en la legislación colombiana otra definición de esclavitud sexual que de manera expresa consagre los 
Análisis Socio Jurídico del delito de secuestro en Colombia a partir de 1970

elementos de esta conducta. Por ello, es necesario examinar otras fuentes -normativas, jurisprudenciales y doctrinarias- que permitan establecer el alcance de este tipo penal. Recurriremos de esta manera, a lo dispuesto en el derecho internacional humanitario, en la Convención sobre la Esclavitud de 1926, en el Estatuto de Roma, y en el informe de la Relatora especial sobre la violación sistemática, la esclavitud sexual y las prácticas análogas de esclavitud en tiempo de conflicto armado, así como a la jurisprudencia de los tribunales internacionales. (Páez, 2010)

En el mismo sentido, podemos afirmar que el punible de toma de rehenes (art 148 cp) es desarrollo del artículo 12 de la que obliga a los Estados signantes de los Convenios de Ginebra de 1949 relativos a la protección de las víctimas de guerra o los Protocolos adicionales a esos Convenios a procesar o entregar al autor de estos hechos. De igual forma, en el Convenio para la represión del apoderamiento ilícito de aeronaves, firmado en La Haya, el 16 de diciembre de 1970, se tipifica como delito el apoderamiento ilícito de aeronaves mediante la violencia, amenaza de violencia y otra forma de intimidación delito incorporado a la legislación interna en el artículo 165 del estatuto penal represor. (Comité Internacional de la cruz Roja, 2012)

En el ámbito regional la Convención Americana sobre Derechos Humanos recoge en su artículo 7 la libertad personal y a nivel orbital se encuentra consagrada en el artículo 9 del Pacto Internacional de Derechos Civiles y Políticos y en el artículo 9 de la Declaración Universal de Derechos Humanos. A pesar de que no existe una definición sobre la detención arbitraria, todos los instrumentos internacionales referidos consagran su prohibición absoluta: "Nadie puede ser sometido a detención o encarcelamiento arbitrarios" (Artículo 7.3 Convención Americana sobre Derechos Humanos) y: "Todo individuo tiene derecho a la 
Análisis Socio Jurídico del delito de secuestro en Colombia a partir de 1970

libertad y a la seguridad personal. Nadie podrá ser sometido a detención o prisión arbitrarias. Nadie podrá ser privado de su libertad, salvo por las causas fijadas por ley y con arreglo al procedimiento establecido en ésta" (Artículo 9.1 Pacto Internacional de Derechos Civiles y Políticos) "Nadie podrá ser arbitrariamente detenido, preso ni desterrado" (Artículo 9 de la Declaración Universal de Derechos Humanos). (OAS, 1969)

Concuerda lo anterior con la resolución 1997/50, emitida por la Comisión de Derechos Humanos de la oficina del Alto comisionado de las Naciones Unidas para los Derechos Humanos, señala tres categorías a partir de las cuales se puede determinar cuando la privación de libertad es arbitraria, veamos: "a) Cuando es evidentemente imposible invocar base legal alguna que justifique la privación de la libertad (como el mantenimiento de una persona en detención tras haber cumplido la pena o a pesar de una ley de amnistía que le sea aplicable), b) cuando la privación de libertad resulta del ejercicio de derechos o libertades proclamados en los artículos 7, 13, 14, 18, 19, 20 y 21 de la Declaración Universal de Derechos Humanos y además, respecto de los Estados Partes, en los artículos 12, 18, 19, 21, 22, 25, 26 y 27 del Pacto Internacional de Derechos Civiles y Políticos y c) cuando la inobservancia, total o parcial, de las normas internacionales relativas al derecho a un juicio imparcial, establecidas en la Declaración Universal de Derechos Humanos y en los instrumentos internacionales pertinentes aceptados por los Estados afectados, es de una gravedad tal que confiere a la privación de libertad carácter arbitrario . (Comisión de Derechos humanos, 1997)

Todos estos preceptos son acatados por el legislador colombiano, en el código penal en su TÍTULO III denominado DELITOS CONTRA LA LIBERTAD INDIVIDUAL Y OTRAS GARANTIAS, consagra en su capítulo cuarto los delitos contra la detención 
Análisis Socio Jurídico del delito de secuestro en Colombia a partir de 1970

arbitraria, cuales son la Privación ilegal de libertad (Artículo 174), la Prolongación ilícita de privación de la libertad (Artículo 175), la Detención arbitraria especial (Artículo 176) y el Desconocimiento de habeas corpus (Artículo 177).

\subsubsection{Países referentes para nuestra legislación Penal}

\subsubsection{España}

En su Código Penal, en el Título VI dentro de los delitos contra la libertad dispone un aparte sobre las detenciones ilegales y secuestros sancionando la conducta realizada por un particular, "cuando este encerrare o detuviere a otro, privándole de su libertad" (ART 163) o "el secuestro de una persona exigiendo alguna condición para ponerla en libertad" (art 164).

Se castiga con una pena mayor cuando el encierro o detención ha durado más de quince días (art 163-3), cuando la detención ilegal o secuestro se ha ejecutado con simulación de autoridad o función pública, o la víctima fuere menor de edad o incapaz o funcionario público en el ejercicio de sus funciones art 165), cuando el reo de detención ilegal o secuestro que no dé razón del paradero de la persona detenida, salvo que la haya dejado en libertad (art 166) o cuando la conducta fuere cometida por autoridad o funcionario público, fuera de los casos permitidos por la Ley, y sin mediar causa por delito (art 166).

En las conductas antes descritas se censura con una pena menor cuando el culpable procura la libertad del encerrado o detenido dentro de los tres primeros días de su detención, sin haber logrado el objeto que se había propuesto (art 163-2), cuando el caso en que el particular que, fuera de los casos permitidos por las leyes, aprehendiere 
Análisis Socio Jurídico del delito de secuestro en Colombia a partir de 1970

a una persona para presentarla inmediatamente a la autoridad (art 163-4) y los casos de provocación, la conspiración y la proposición para cometer esa clase de delitos (art 168). (Código Penal y Legislación Complementaria, 2016)

\subsubsection{Italia}

En el Libro Segundo del Código Penal Italiano denominado DELITOS PARTICULARES dentro del Título I DE LOS DELITOS CONTRA EL ESTADO, obra el capítulo I: De los atentados contra la condición internacional, dentro de él está su artículo 289 bis denominado secuestro con fines de terrorismo o subversión, el cual lo comete cualquier persona con el propósito de terrorismo o subversión y es reprimido con prisión de veinticinco a treinta años. Si el autor causa la muerte de la persona secuestrada se aplica la cadena perpetua.

Igualmente dicho artículo sanciona el pago del rescate con prisión de dos a ocho años y si el sujeto pasivo muere como resultado del secuestro, después de la liberación, la pena es de prisión de ocho a los dieciocho años.

Dentro de la Sección I De los atentados contra LIBERTAD PERSONAL, Título XII: atentados contra la persona, Capítulo I: De los atentados contra la vida e integridad personal Art. 600 sanciona la reducción a la esclavitud con prisión de cinco a quince años, al igual que se castiga en el artículo 601 la trata de esclavos con prisión de cinco a veinte años.

En la Sección II llamada De los atentados contra la libertad de la persona, en el artículo 605 aparece el tipo penal de secuestro simple sancionado con prisión de seis meses a 
Análisis Socio Jurídico del delito de secuestro en Colombia a partir de 1970

ocho años, pena que es agravada de uno a diez años si el delito se comete en perjuicio de un ascendiente, descendiente o cónyuge ò por un funcionario público con abuso de poder inherente a sus funciones. (Código Penal de Italia, 1930, Pág., 71)

\subsubsection{Alemania}

En el Código Penal Alemán Sección XVIII delitos contra la libertad personal en su artículo 234 se tipifica el secuestro, en el que incurre quien mediante violencia o amenaza de un gran malestar o mediante engaño exponga a otra persona a situación de desamparo, a esclavitud o servidumbre sancionando con una pena de prisión de seis meses a cinco años.

En el mismo sentido, el secuestro extorsivo se establece en el artículo 239 A, tipificando la conducta de secuestrar a una persona con el fin de explotar o chantajear, sancionándolo con prisión no menor de cinco años y en los casos menos graves, la pena será privativa de libertad no menor de un año. Si el autor causa por el acto al menos imprudentemente la muerte de la víctima, la pena será de cadena perpetua o prisión por lo menos de diez años. (Código Penal de Alemania, 1871, Pág., 96)

\subsubsection{Puerto Rico}

En el capítulo V del Código Penal de Puerto Rico denominado "Delitos Contra los Derechos Civiles”, específicamente en la sección primera, De las restricciones a la libertad, se tipifica el delito de secuestro, el cual comete toda persona que mediante 
Análisis Socio Jurídico del delito de secuestro en Colombia a partir de 1970

fuerza, violencia, intimidación, fraude o engaño, sustrae, o retiene y oculta, a otra persona privándola de su libertad. Para que se configure el delito de secuestro no es necesario que la sustracción sea por tiempo y distancia sustancial; basta con el movimiento o traslado de un lugar a otro (art 157).

Las circunstancias de agravación se desarrollan cuando el delito se cometa contra una persona que no ha cumplido dieciocho (18) años de edad, o un discapacitado o persona que no pueda valerse por sí misma, o un enfermo mental, cuando se cometa contra el Gobernador de Puerto Rico, contra un legislador o Secretario del Gabinete o funcionario principal de una agencia o corporación pública, juez, fiscal especial independiente, o un fiscal o procurador del Departamento de Justicia de Puerto Rico, fuere éste nombrado por el Gobernador de Puerto Rico o designado como tal por el Secretario de Justicia, Cuando se cometa con el propósito de exigir compensación monetaria o que se realice algún acto contrario a la ley o a la voluntad de la persona secuestrada, o exigir al Estado la liberación de algún recluso cumpliendo sentencia o la liberación de una persona arrestada o acusada en relación con la comisión de algún delito o cuando el secuestro se inicie fuera de los límites territoriales del Estado Libre Asociado de Puerto Rico y se traiga o envíe a la persona a Puerto Rico. (Art 158).

En la Legislación Penal Puertorriqueña, se destaca como delito autónomo el secuestro de menores, que ocurre cuando se utiliza la fuerza, violencia, intimidación, fraude o engaño sustraiga a un menor con el propósito de retenerlo y ocultarlo de sus padres, tutor u otra persona encargada de dicho menor. Como circunstancias de agravación se consideran cuando ocurren en una institución hospitalaria, pública o privada, en una escuela elemental, intermedia o secundaria, pública o privada, en un edificio ocupado 
Análisis Socio Jurídico del delito de secuestro en Colombia a partir de 1970

o sus dependencias, en un centro de cuidado de niños; o un parque, área recreativa o centro comercial.

En el mismo sentido se establecen como delitos autónomos, conductas relacionadas con el secuestro y retención de personas como lo son la Servidumbre involuntaria o esclavitud (Art 159), Trata humana (Art 160), detención ilegal y Prolongación indebida de la pena (Art 165). (Código Penal de Puerto Rico, 2012)

\subsubsection{Chile}

Dentro del Título III del Código Penal Chileno DE LOS CRIMENES Y SIMPLES DELITOS QUE AFECTAN LOS DERECHOS GARANTIDOS POR LA CONSTITUCION, justamente en el numeral 3 se enumeran los crímenes y simples delitos contra la libertad y seguridad cometidos por particulares, ubicando dentro de ellos al secuestro, definiéndolo como la acción que comete el que sin derecho encerrare o detuviere a otro privándole de su libertad, o proporcionare el lugar para la ejecución del delito. (Art. 141)

Como circunstancias que ameritan la imposición de una pena más severa, están las de ejecutar el secuestro para obtener un rescate o imponer exigencias o arrancar decisiones, cuando el encierro o la detención se prolongare por más de quince días o si de ello resultare un daño grave en la persona o intereses del secuestrado, cuando con motivo u ocasión del secuestro cometiere además homicidio, violación, violación sodomítica o lesiones y cuando la sustracción de un menor de 18 años será castigada con presidio mayor en su grado máximo a presidio perpetuo, si se ejecutare para 
Análisis Socio Jurídico del delito de secuestro en Colombia a partir de 1970

obtener un rescate, imponer exigencias, arrancar decisiones o si resultare un grave daño en la persona del menor. (Art 141 y 142).

En la Legislación Penal Chilena no se sanciona el rapto como conducta delictiva, al haber sido derogados los artículos 358 y siguientes del Código Penal, por el artículo 1 numeral 4 de la ley 19617 expedida el 12 de julio de 1999. (Código Penal de Chile, 1874)

2.2.2.6 Países Latinoamericanos afectados mayormente con el fenómeno del secuestro Los secuestros son una dificultad que concurren en varios países de la región, el informe de Desarrollo Humano de ONU correspondiente a 2014 advirtió la creciente presencia de redes de narcotráfico y criminalidad organizada dedicados a la extorsión, lo que requiere en los gobiernos acciones para fortalecer la presencia policial. (Programa de las Naciones Unidas, 2016, p. 97)

Como se indicó en el capítulo anterior, para el 2013 la tasa de secuestros en México fue de 2663, en Colombia de 299 y en Venezuela de 382. Por ello se considera necesario estudiar cual es la legislación vigente en estos países en materia de secuestro, junto con otros que igualmente han sufrido este fenómeno.

\subsubsection{México}

En el Código Federal Penal, en el TÍTULO VIGESIMO PRIMERO denominado Privación Ilegal de la Libertad y de otras Garantías, en un CAPITULO ÙNICO 
Análisis Socio Jurídico del delito de secuestro en Colombia a partir de 1970

sanciona la conducta del particular que prive a otro de su libertad, aumentando la pena cuando la privación de la libertad se realice con violencia, cuando la víctima sea menor de dieciséis o mayor de sesenta años de edad, o cuando por cualquier circunstancia, la víctima esté en situación de inferioridad física o mental respecto de quien la ejecuta (art 364).

En el mismo sentido, se sanciona con penas más drásticas si la privación de la libertad se efectúa con el propósito de Obtener rescate, de detener en calidad de rehén a una persona y amenazar con privarla de la vida o con causarle daño, para que la autoridad o un particular realice o deje de realizar un acto cualquiera, causar daño o perjuicio a la persona privada de la libertad o a cualquier otra, o cometer secuestro exprés; así mismo, cuando se realice en camino público o en lugar desprotegido o solitario, cuando el autor sea o haya sido integrante de alguna institución de seguridad pública, o se ostente como tal sin serlo, cuando se lleva a cabo obren en grupo de dos o más personas, cuando se realice con violencia, o cuando la víctima sea menor de dieciséis o mayor de sesenta años de edad, o que por cualquier otra circunstancia se encuentre en inferioridad física o mental respecto de quien ejecuta la privación de la libertad. Se aplicarán penas hasta de cincuenta años de prisión, cuando la privación de libertad se efectúe con el fin de trasladar a un menor de dieciséis años fuera de territorio nacional, con el propósito de obtener un lucro indebido por la venta o la entrega del menor y hasta de sesenta cuando el secuestrado sea privado de la vida por su o sus secuestradores. (Art 366)

En la mencionada norma se establecen como circunstancias de atenuación la liberación espontánea del secuestrado dentro de los tres días siguientes al de la privación de la 
Análisis Socio Jurídico del delito de secuestro en Colombia a partir de 1970

libertad, sin lograr alguno de los propósitos establecidos y se sancionan como delictivas las conductas de obligar a otro a prestarle trabajos o servicios personales sin la retribución debida, celebrar con otro un contrato que prive a éste de la libertad o le imponga condiciones que lo constituyan en una especie de servidumbre o que se apodere de alguna persona y la entregue a otro con el objeto de que éste celebre dicho contrato, privar ilegalmente a otro de su libertad con el propósito de realizar un acto sexual (Art 365 bis).

Se penalizan además la actuación como intermediario en las negociaciones del rescate, sin el acuerdo de quienes representen o gestionen en favor de la víctima, colaborar con la difusión de mensajes de los secuestradores, actuar como asesor con fines lucrativos , aconsejar el no presentar la denuncia del secuestro cometido o Intimidar a la víctima, a sus familiares o a sus representantes o gestores, durante o después del secuestro, para que no colaboren con las autoridades competentes (art 366 bis). (Código Federal Penal, 2014)

\subsubsection{Venezuela}

Dentro del Código Penal de Venezuela, en el CAPITULO III llamado De los delitos contra la libertad individual se sanciona a cualquier persona que reduzca a esclavitud a alguna persona o la someta a una condición análoga , al que intervenga en la trata de esclavos (art 174), al que ilegítimamente haya privado a alguno de su libertad personal (art 175). Se aumenta la pena cuando el culpable para cometer el delito o durante su comisión, hizo uso de amenazas, sevicia o engaño, o si lo cometió por espíritu de 
Análisis Socio Jurídico del delito de secuestro en Colombia a partir de 1970

venganza o lucro, o con el fin o pretexto de religión, o si secuestró la persona para ponerla al servicio militar de país extranjero (art 175).

En el mismo sentido se hace más drástica la sanción, cuando el delito se ha cometido contra algún ascendiente o cónyuge, contra algún miembro de la Asamblea Nacional; de los Consejos Legislativos de los Estados, contra algún Magistrado del Tribunal Supremo de Justicia o contra cualquier otro Magistrado Público, por razón de sus funciones, o si del hecho ha resultado algún perjuicio grave para la persona, la salud o los bienes del agraviado (art 176). Por el contrario, se atenúa la pena imponible cuando el culpable, espontáneamente, ha puesto en libertad a la persona antes de toda diligencia de enjuiciamiento, sin haber conseguido el fin que se proponía ni haberle ocasionado daño alguno.

La Legislación Penal Venezolana, caracteriza como delito autónomo el RAPTO cuando una persona con el objeto extraño al de satisfacer sus propias pasiones, de contraer matrimonio o de realizar alguna ganancia hubiere arrebatado a una persona, menor de quince años, aun consintiéndolo ella, del lado de sus padres, tutores o demás guardadores siquiera sean temporalmente (art 178). (Código Penal de Venezuela, 2000)

\subsubsection{Brasil}

En el capítulo sexto del Código Penal de Brasil llamado DE LOS CRIMENES CONTRA LA LIBERTAD INDIVIDUAL, específicamente en la primera SECCIÓN denominada DE LOS CRIMENES CONTRA LA LIBERTAD PERSONAL, aparecen 
Análisis Socio Jurídico del delito de secuestro en Colombia a partir de 1970

sancionadas las conductas de secuestro y prisión privada consistente en Privar a alguien de su libertad, mediante secuestro o prisión privada (art 148). Como circunstancias de aumento de pena se instauran la condición de la víctima de ser ascendiente, descendiente, cónyuge o compañero del delincuente o mayor de 60 (sesenta) años, si el crimen es practicado mediante internación de la víctima en casa de salud u hospital ,si la privación de la libertad dura más de quince días, si el crimen es practicado contra menor de 18 (dieciocho) años, si el crimen es practicado con fines libidinosos y si se ocasiona a la víctima, en razón de malos tratos o de la naturaleza de la detención, grave sufrimiento físico o moral (art 148).

Se sanciona como tipo penal autónomo el de extorsión mediante secuestro, consistente en secuestrar persona con el fin de obtener para sí o para otra persona, cualquier ventaja como condición o precio del rescate, con circunstancias que aumentan la pena cuando el secuestro dura más de 24 (veinticuatro) horas, si el secuestrado es menor de 18 (Dieciocho) o mayor de 60 (sesenta) años o si el crimen es cometido por banda o cuadrilla, si del hecho resulta lesión corporal de naturaleza grave, si resulta la muerte. Se da como causal de atenuación en este último caso cuando el crimen es cometido en conjunto, el participante que lo denuncie a las autoridades facilitando la liberación del secuestrado (art 149). En la legislación de Brasil hasta el año 2005 aparecía penalizado el delito de rapto en los artículos 219 y siguientes del estatuto penal, siendo derogadas estas normas mediante la ley 11106 de 2005. (Código Penal de Brasil, 1998) 
Análisis Socio Jurídico del delito de secuestro en Colombia a partir de 1970

\subsubsection{Guatemala}

En el título sexto del Código Penal Guatemalteco denominado DE LOS DELITOS CONTRA LA LIBERTAD Y LA SEGURIDAD DE LA PERSONA, en el CAPITULO I DE LOS DELITOS CONTRA LA LIBERTAD INDIVIDUAL se enlista el PLAGIO O SECUESTRO, sancionando a los autores materiales o intelectuales del delito de plagio o secuestro de una o más personas con el propósito de lograr rescate, canje de personas o la toma de cualquier decisión contraria a la voluntad del secuestrado o con cualquier otro propósito similar o igual, destacando que a quienes se hallaren culpables se les aplicará la pena de muerte y cuando ésta no pueda ser impuesta, se aplicará prisión de veinticinco a cincuenta años sin derecho a aplicar ninguna circunstancia atenuante o rebaja de pena.

Se acentúa la tipificación autónoma del delito de rapto en el capítulo cuarto del código penal, dividiéndolo en propio, impropio y específicamente agravado, propio cuando con propósitos sexuales sustrajere o retuviere a una mujer, sin su voluntad o empleando violencia o engaño (art 181), impropio cuando se sustrajere o retuviere a mujer mayor de doce años y menor de diez y seis, con propósitos sexuales, de matrimonio o de concubinato, con su consentimiento (art 182) y específicamente agravado cuando la persona raptada fuere de menor de doce años (art 183). Como circunstancia de aumento de pena surge la desaparición de la raptada, si los raptores no probaren el paradero de la víctima o que su muerte o desaparición se debió a causas ajenas al rapto, serán sancionados con prisión de seis a doce años y como atenuante cuando la persona desaparecida fuere encontrada (art 184). (Código Penal de Guatemala, 1973). 
Análisis Socio Jurídico del delito de secuestro en Colombia a partir de 1970

\subsection{Jurisprudencial}

Sobre el tema del secuestro y sus diferentes modalidades, la Sala Penal de la honorable Corte Suprema de Justicia, ha puntualizado diferentes conceptos, los cuales se pretenden referenciar teniendo como base algunas de sus principales decisiones en cada uno de los temas.

\subsubsection{Secuestro simple y secuestro extorsivo}

A nivel Jurisprudencial desde la década de los 90`s se han venido decantando los conceptos de secuestro y las diferencias que se pueden presentar entre los conceptos de secuestro simple y extorsivo. Es así como la Sala Penal de la honorable Corte Suprema de Justicia en sentencia de casación dictada dentro del Proceso $\mathrm{N}^{\mathrm{o}}$ 13384, "buscó eliminar cualquier inquietud que pudiera verse reflejada, sobre la manera como se adecuaron en la ley penal dada la descripción típica que se hace en el Decreto 100 de 1.980 artículos 268 y 269 de los secuestros extorsivo y simple" (Corte Suprema De Justicia Sala De Casación Penal, M.P. Carlos Augusto Gálvez Argote, 14 de abril de 2000). Refiere la Sala que:

Al introducir dentro de los elementos estructurales del primer modelo algunos ingredientes comportamentales subjetivos, se debe entender que cuando se arrebata, sustrae, retiene u oculta a una persona con el propósito de exigir por su liberación un provecho o cualquier utilidad, si bien en principio puede no ser el referido beneficio de contenido patrimonial, indefectiblemente cuando la finalidad pretendida es de esta índole, la correcta adecuación de la conducta corresponde al secuestro extorsivo .

En decisión de 2009 la Sala Penal (CSJ SP 11 mar. 2009, rad. 28.563 MP. Alfredo Gómez Quintero), destaca que el delito de secuestro ha tenido tradicionalmente como bien jurídico 
Análisis Socio Jurídico del delito de secuestro en Colombia a partir de 1970

protegido la libertad individual lo que se traduce en la privación a otro del derecho de locomoción, entendido como la posibilidad de disponer según su voluntad del lugar en el que quiere permanecer o ir.

Para la Sala Penal de La Corte, emerge como elemento diferenciador de las modalidades de secuestro simple y extorsivo, la introducción de ingredientes subjetivos específicos para este último, esto es, que el delito se cometa con el propósito de exigir por la libertad un provecho o cualquier utilidad, o para que se haga u omita algo, o con fines publicitarios o de carácter político, en tanto que el secuestro simple obedece a "propósitos distintos" a los enunciados.

\subsubsection{Sobre la licitud de la exigencia en el secuestro}

Sobre la exigencia de la licitud o la ilicitud de la exigencia requerida para que la víctima recobrara su libertad, señalo la Sala Penal: Proceso No 13384 Corte Suprema De Justicia Sala De Casación Penal M. P. Carlos Augusto Gálvez Argote 14 de abril de 2000:

(...) corresponde, por supuesto, a la lógica de un sistema fundado en la protección de bienes jurídicos previamente configurados. De acuerdo con ella, si a través de tipo de secuestro se pretende la tutela de la libertad, mal puede condicionarse ese objetivo a la presencia o ausencia de valoraciones que lo harían irrealizable... Una exigencia de que la utilidad propuesta en el secuestro sea ilícita, implicaría la autorización de que pueda privarse de la libertad a una persona para demandar el cumplimiento de prestaciones lícitas, con lo cual el tipo estaría paradojalmente, prohibiendo y permitiendo la conducta en postura verdaderamente absurda. 
Análisis Socio Jurídico del delito de secuestro en Colombia a partir de 1970

\subsubsection{Secuestro por los padres}

En la época anterior a 2004, la conducta de arrebatar, sustraer, retener u ocultar a su hijo menor, con el fin de privarlo de la custodia o cuidado personal, podría ser castigada como constitutiva del delito de secuestro simple consagrado en el artículo 168 de la ley 599 de 2000.

Es así como, aun en vigencia del decreto 100 de 1980, la Sala Penal de la Corte Proceso N 11808 Corte Suprema De Justicia Sala De Casación Penal M. P. Carlos Augusto Gálvez Argote, 25 de mayo de 2000, desestimó los argumentos del defensor de un padre de familia condenado como autor del delito de secuestro simple agravado, por privar de la custodia a la madre de sus hijas menores de edad. Y precisamente la Sala Penal, señala que no son de recibo las razones de la defensa que alegaba una interpretación excesiva del artículo 2 de la ley 40 de 1993 con la cual el legislador introdujo modalidades delictuales reguladas adjudicándole severas penas, buscando perseguir una determinada delincuencia de grave trascendencia social.

Para la defensa, el legislador en ese momento, no distinguió entre el secuestro cometido mediante engaño en relación con las personas que disponen libremente de locomoción y las que no tienen una tal posibilidad por ser incapaces, bien por minoría de edad u otros factores que impidan su autodeterminación y en esa medida "dilucidar", cuál de los padres estaba amparado por las disposiciones legales para disponer del destino de sus hijas, teniendo en cuenta no solo que por tratarse de menores no lo podrían decidir éstas, sino que por hallarse divida la residencia de aquellos en razón a sus desavenencias matrimoniales.

Sobre el punto la Sala Penal resaltó que con la actuación del padre se afectó la libertad de locomoción de las menores, puesto que en condiciones normales estarían sujetas al ámbito de control de sus padres o individualmente según el caso, pero siempre con el consentimiento del 
Análisis Socio Jurídico del delito de secuestro en Colombia a partir de 1970

otro. En el caso la custodia la tenía la madre, de lo que podría resultar una vulneración superior, lo cual evidentemente genera rechazo social porque afecta las relaciones familiares puestas a nivel del núcleo societario.

En la actualidad tal situación se encuentra superada ya que la Ley 890 de 2004 en su artículo 7, creó como tipo penal autónomo el articulo 230 A denominado EJERCICIO ARBITRARIO DE CUSTODIA DE MENOR DE EDAD, al respecto la Sala Penal se ha pronunciado de la siguiente manera: Proceso $\mathrm{n}^{\mathrm{o}} 36603$ Corte Suprema De Justicia Sala De Casación Penal M. P. Fernando Alberto Castro Caballero 6 de julio de 2011:

De otro lado, valga destacar que con el delito de secuestro extorsivo, el legislador quiso proteger no sólo el bien jurídico de la libertad individual sino el patrimonio económico. De manera que se incurre en secuestro cuando se arrebata, sustrae, retiene u oculta a una persona, a fin de obtener un resultado previsto en la norma, esto es, que a cambio de la liberación se hace una exigencia, la cual puede ser para obtener un provecho económico, publicitario, político, cualquier otra utilidad o para que se haga u omita algo.

Mientras que con la conducta punible de ejercicio arbitrario de la custodia de hijo menor de edad, si bien es cierto, es el padre o la madre del niño quien arrebata, retiene u oculta sobre quien se ejerce la patria potestad, el fin último del comportamiento es el de privar al otro padre del derecho de custodia. 
Análisis Socio Jurídico del delito de secuestro en Colombia a partir de 1970

\subsubsection{Secuestro en el paseo millonario}

Según estudio realizado por el observatorio del delito de la Policía Nacional de Colombia, en la mayoría de los países, la conducta denominada "paseo millonario" consistente en la retención de una persona para obtener de ella un provecho económico, por ejemplo hurtar dinero sustrayéndolo de sus tarjetas débito en cajeros electrónicos, puede considerarse como un hurto simple, algunas veces junto con la privación de la libertad, sin embargo, se deba analizar en cada caso ya que existen países como lo es México que tipifica como delito autónomo el secuestro exprés.

En Colombia, la Sala Penal de La Corte Suprema de Justicia ha llegado a la conclusión que al existir efectiva privación de la libertad de la víctima con miras a la obtención de un provecho se configura delito de secuestro extorsivo, se puede relacionar el precedentes del 29 de marzo de 2000, Radicado 13311, Casación No 32823 del 11 de diciembre de 2009 MP JOSE LEONIDAS BUSTOS MARTINEZ, sentencia del 25 de mayo de 2006 Radicado 20326, resaltando en este último pronunciamiento que es jurídicamente atinado predicar el secuestro extorsivo cuando convergen varias notas características:

1) El propósito de los implicados de obtener un provecho de naturaleza económica, 2) la utilización de la retención de los sujetos pasivos en contra de su voluntad como medio para lograrlo, 3) la restricción de la libertad física de las víctimas se emplea para evitar que acudan en defensa de su patrimonio y 4) que la liberación de las víctimas se supedite o condicione a la obtención del provecho económico así no se haya logrado. 
Análisis Socio Jurídico del delito de secuestro en Colombia a partir de 1970

\subsubsection{Secuestro de aeronaves, naves o medios de transporte colectivo}

A mediados de la década de los 90 en la ciudad de Bogotá D.C, puntualmente el 24 de mayo de 1994, sucedieron hechos delictivos en los cuales varios sujetos interceptaron y abordaron un autobús tipo ejecutivo de servicio urbano que llevaba en su interior un número cercano a los cuarenta pasajeros, y estando dentro de él, mediante la exhibición de armas de fuego y corto punzantes, le arrebataron el control del vehículo al conductor, apagaron las luces interiores del automotor, le subieron el volumen al radio, obligando a los hombres a que se tendieran sobre el piso, los amarraron, desviaron el curso del bus por diferentes sectores de la ciudad, mientras despojaban a los ocupantes de bienes personales tales como dinero, alhajas, documentos y prendas de vestir, llegando al extremo de abusar sexualmente de algunas de las damas que viajaban en el rodante.

En ese caso las personas que fueron judicializadas, resultaron en algunos casos condenadas a título de coautoría entre otros delitos los de secuestro de nave, aeronave o medio de transporte colectivo y hurto calificado y agravado. En sede de casación la Sala Penal de La Corte Suprema de Justicia, desestimó los planteamientos de la defensa, que entre otros argumentos esgrimía que se trataba de un acto en el cual para poder desplegar el hurto era necesario el apoderamiento del control del vehículo y el desvío de su ruta, pues se corría el riesgo de que el automotor llegara a su destino sin que los asaltantes hubiesen terminado su labor de apoderamiento.

Por el contrario, estimó La Corte que concurre en ese caso como delito autónomo el de secuestro de nave, aeronave o medio de transporte público además del hurto, pues para éstos era suficiente el amedrentamiento procurado con las armas y la fuerza 
Análisis Socio Jurídico del delito de secuestro en Colombia a partir de 1970

desplegada al momento de su consumación, no era necesario desviar el curso del medio de transporte, concluyéndose en la decisión que el apoderamiento y desvío del vehículo de servicio colectivo también estaba previsto como conducta independiente en el plan delictivo y de ahí el concurso de hechos punibles. (Corte Suprema de Justicia, Proceso $N^{\circ} 14120$, Febrero de 2000)

\subsubsection{Secuestro y trata de personas}

La Sala Penal de La Corte Suprema de Justicia ha referido sobre los verbos rectores previstos en la norma colombiana para el delito de trata de personas, como son los de captar implica atraer a alguien, ganar su voluntad; trasladar es llevar a una persona de un lugar a otro; acoger equivale a suministrarle refugio, albergue, o techo; y recibir es tomar o hacerse cargo de alguien que es entregado por un tercero. Tales acciones pueden ejecutarse, como lo prevé la norma internacional, mediante amenazas, a través del uso de la fuerza u otras formas de coacción, como el rapto, el fraude, el engaño, o abusando del poder o confianza que se detenta sobre la persona o aprovechando de la situación de vulnerabilidad en que se halla, medios que no son exigibles cuando la víctima es un niño. Además La Corte precisa que estas acciones pueden cumplirse dentro del territorio nacional o hacia el exterior, y que el ingrediente subjetivo de la conducta punible, consistente en la finalidad de explotación.

La Sala Penal ha enfatizado en que el sujeto activo (plural o individual) de la conducta punible de trata de personas, al desarrollar el iter criminal, puede, y de hecho así ocurre en la práctica, incurrir en diferentes comportamientos lesivos de otros bienes 
Análisis Socio Jurídico del delito de secuestro en Colombia a partir de 1970

jurídicamente tutelados, como por ejemplo, el secuestro, la falsificación de documentos, etc., sin que por ello desaparezca el fin último perseguido y concretado, esto es, la mercantilización o comercio de un ser humano, ni el real o efectivo concurso de tipos penales, cuya adecuada y completa atribución corresponde hacerla al órgano encargado de la persecución penal. (Corte Suprema de Justicia, Proceso Nº 39257, 16 de octubre de 2013)

\subsubsection{Secuestro Como Medio De Guerra}

Para la Sala Penal de La Corte Suprema de Justicia el secuestro de civiles resulta ajeno al conflicto armado interno, habida cuenta que está proscrito en el derecho internacional humanitario como método de guerra. En decisión de julio de 2004, Proceso No 14538 Corte Suprema De Justicia Sala De Casación Penal M.P. LUIS QUINTERO MILANES reiteró lo dicho en providencia del 2 de diciembre de 1998, así:

La tesis expuesta por los casacionistas en el sentido de que, entre los delitos de rebelión y secuestro extorsivo de personas civiles ajenas al conflicto armado, existe una relación de extensión comprensión, en razón de que el primero recoge al segundo, debiéndose aplicar solo la pena para el delito político, es jurídicamente insostenible.

Agregando,

El secuestro de personas civiles ajenas al conflicto armado interno, está proscrito por el derecho internacional humanitario como medio o método de guerra, razón por la cual su ejercicio deviene de ilegítimo. De ahí que no pueda ser catalogado como actividad propia de la empresa subversiva, ni como acto de combate. 
Análisis Socio Jurídico del delito de secuestro en Colombia a partir de 1970

\subsection{Doctrinal}

La organización de Estados Americanos da al secuestro la connotación de detención ilegal de una persona o varias personas contra su voluntad (incluso mediante el uso de la fuerza, la amenaza, fraude o engaño) con el propósito de exigir por su liberación un provecho ilícito o cualquier otro beneficio económico u otro beneficio de orden material, o en para obligar a alguien a hacer o no hacer algo. "Secuestro" incluye las disputas por la custodia del niño. (Organización de Estados Americanos, Observatorio, 2016. p.1)

En la Legislación Penal se suele definir ese delito con alcance más limitado que en la definición lingüística, ya que se configura por el hecho de que el secuestro se realice con el propósito, logrado o no, de obtener rescate, y de ahí que se haya incluido entre los delitos contra la propiedad y, dentro de ellos, entre los de extorsión. Si el secuestro -es decir, la aprehensión ilícita de una persona- tuviese otro objeto, constituiría un delito de privación de la libertad individual o bien un delito de rapto.

En el secuestro de personas, la pena puede ser más o menos grave según que se haya obtenido, o no. el rescate. Lo que tipifica el delito examinado no es solamente la intención lucrativa, sino el modo de lograrla, pues en la legislación también se prevé que el delito de privación de la libertad individual se cometa con propósito de lucro. En la nueva definición de ambos delitos no se advierte una clara diferencia. Fontán Balestra la explica diciendo que en el delito de privación de libertad con propósito de lucro, éste se ha de obtener de la misma víctima, mientras que, en el secuestro, la privación de libertad no es sino el medio para cometer la extorsión. A su vez, Nocetti Fasolino dice que, en aquel delito, la detención de la víctima hace posible el lucro una 
Análisis Socio Jurídico del delito de secuestro en Colombia a partir de 1970

vez realizada, en tanto que en éste el lucro depende de la recuperación de la libertad del secuestrado, la que sólo se realiza contra la entrega del dinero. Cabría añadir, aclarando esos conceptos, que en el delito de secuestro la extorsión puede no dirigirse, y generalmente no se dirige, contra el secuestrado, sino contra terceras personas.

Para Francesco Carrara, el secuestro extorsivo ha consistido en reducir a un hombre a disposición del autor y tenerlo prisionero hasta que la familia haya proporcionado una suma determinada, incluyendo esto un plazo y amenazando hasta con la muerte, en caso de que no se cumplan las condiciones. La posición de Carrara era que se trataba de un hurto con rescate, que no es otra cosa que un hurto violento, porque uno y otro atacan la libertad individual como medio de lucro, con la diferencia de que el primero ofende a la libertad de manera más pronunciada y durable. (Carrara, 1996, Pág., 178)

Para Soler, el secuestro extorsivo se trata sin duda, de una extorsión y por ende de un delito en contra de la propiedad, cuyo medio intimidatorio es la llamada "detención en rehenes", de manera que se afecta la libertad de la persona. Al tratarse de un delito contra la propiedad, la privación de libertad, aunque en sí misma grave, es tenida en cuenta por el delincuente como el medio extorsivo, por lo cual son independientes del modus operandi de este delito, las violencias que se ejerzan para la privación de la libertad. La característica de este hecho consiste en que el sujeto se sirve del poder coactivo de la privación de libertad en sí misma, y por eso se da un caso de intimidación o coacción. (Soler, 1992, p. 331)

La idea de Núñez (1951) sobre el delito es que: 
Análisis Socio Jurídico del delito de secuestro en Colombia a partir de 1970

Se trata de una extorsión caracterizada por la intimidación, que ahora resulta de la privación de libertad personal, con la diferenciación del artículo 168, en que se anticipa el momento consumativo del delito, en cuanto no se exige que el autor consiga su objetivo. (Núñez, 1951, p. 7).

Sobre el tipo subjetivo, afirma que: "el delito es doloso ya que el sujeto activo actúa con el conocimiento y la voluntad de privar de la libertad a una persona para sacar un rescate y esta finalidad del autor constituye un dolo directo" (Núñez, 1951, p. 273).

Para Creus (1998) las acciones típicas en el secuestro son las de sustraer, retener u ocultar. Por sustracción debe entenderse la acción de sacar a la persona del lugar en que se encuentre, del lugar al que pertenece, donde desenvuelve su vida en libertad, o bajo la guarda de terceros. Retener es obligar a la persona a permanecer en un lugar determinado durante un lapso que puede ser más o menos prolongado, lo que lo saca de su ámbito de libertad. Ocultar equivale a esconder a la persona, lo cual se logra trasladándola a un lugar desconocido por terceros, de modo que se dificulte la acción de encontrarla. El citado autor agrega que la sustracción implica un desplazamiento de la persona, el que no es indispensable en la retención, acción en la que el acto de impedir la libertad ambulatoria del sujeto ya implica mantenerlo fuera de su esfera de libertad; en tanto que la acción de ocultar tiene que referirse a una persona ya sustraída o retenida, que alcanza importancia dogmática cuando quien la realiza es un agente que no ha intervenido en el secuestro o la retención, porque la realización sucesiva de esas acciones por parte del mismo autor no multiplica la delictuosidad. (Creus, 1998, p. 456) 
Análisis Socio Jurídico del delito de secuestro en Colombia a partir de 1970

Creus (1998) afirma que es insuficiente el simple ánimo de lucro, si dicho ánimo no se traduce en la pretensión de obtener rescate. En el ejemplo de Creus, quien instigado por otro priva de libertad a un tercero, por el precio que le ofrece para que cometa el delito, no comete secuestro extorsivo sino un delito contra la libertad, para el autor además el secuestro extorsivo debe tener pena más grave cuando el autor logre su propósito, es decir, cobre el rescate. "Es insuficiente que el sujeto pasivo se haya desprendido de los bienes que componen ese precio, si ellos no ingresaron en la esfera de disposición del agente o del tercero designado por él” (Creus, 1998, p. 457 y 459).

Para Donna, Cuando se afirma que el delito de secuestro extorsivo, o rescate, es un tipo de peligro, hay que ubicarlo en su contexto exacto, porque la afirmación es cierta sólo en cuanto a la propiedad, ya que el delito se consuma con la finalidad del agente de causar un perjuicio patrimonial, pero no hay que olvidar que la libertad de la persona ha sido eliminada, de modo que, en ese sentido, el bien jurídico ha sido eliminado. Es un delito permanente, pues su consumación se mantiene mientras dure la detención del rehén para sacar rescate, lo que es importante a los efectos de la prescripción. (Donna, 2001, p. 234)

Muñoz (2015) afirma que:

Bajo la rúbrica de detenciones ilegales y secuestros se tipifican una serie de delitos que inciden en la libertad ambulatoria de las personas, entendida como el más elemental y capital aspecto de la libertad humana; considera sin embargo que estos delitos solo son una variante de las coacciones, con la diferencia que estos afectan solo un aspecto de la libertad genéricamente considerada., siendo difícil esta distinción ya que hay 
Análisis Socio Jurídico del delito de secuestro en Colombia a partir de 1970

supuestos en las coacciones en los que también se priva de la libertad ambulatoria, como es el caso del suministro de narcótico o atar a una persona. (Pág., 148) 
Análisis Socio Jurídico del delito de secuestro en Colombia a partir de 1970

\section{Capítulo III. Definición Dogmática del Delito de Secuestro}

\section{Tipo Básico}

El secuestro puede ser simple o extorsivo. El artículo 168 del Código Penal modificado por el artículo 1 de la ley 733 de 2002 y por el artículo 14 de la ley 890 de 2004 se refiere a la primera modalidad así: "El que con propósitos distintos a los previstos en el artículo siguiente, arrebate, sustraiga, retenga u oculte a una persona”. En consecuencia, tal como lo advierten Arboleda y Ruiz (2002):

El delito de secuestro se establece cuando se arrebate esto es que se tome con violencia, sustraiga, que vale tanto como aparte, extraiga o hurte fraudulentamente; retenga en el sentido de detener u ocultar esto es esconder o encubrir a la vista, siempre que estos comportamientos se hubieren realizado sobre una persona. Por otra parte el secuestro extorsivo de conformidad con el artículo 169 del cp, lo es por el solo hecho de con las conductas descritas en el art 168, se pretenda obtener provecho o utilidades ilícitas. (p. 494)

\subsection{Tipo Objetivo}

Dentro de la estructura y clasificación de los tipos penales a nivel general, ha explicado que en esta composición están algunas cuestiones generales que de un modo constante están siempre presentes en la composición de todos los tipos, estos son el sujeto activo, la conducta y el bien jurídico. (Muñoz, 2015, p. 273) 
Análisis Socio Jurídico del delito de secuestro en Colombia a partir de 1970

Coincide lo anterior con lo expuesto por el profesor Velásquez (2010) quien afirma que: “el esquema básico de cualquier figura punible se compone de tres exigencias básicas: el sujeto, la conducta (en este caso la acción en sentido estricto) y el bien jurídico" (p. 349). En consecuencia, sobre esta base se realizará el correspondiente estudio, de la siguiente manera:

\subsubsection{Sujetos}

\subsubsection{Activo}

El tipo penal de secuestro no exige una cualidad especial para ser considerado como autor, por lo que en principio puede ser cualquier persona; sin embargo, cuando se trata de un servidor público y/o persona que sea o haya sido miembro de las fuerzas de seguridad del Estado, será una circunstancia que se toma como agravante de conformidad con el articulo 170 núm. 5 del Código Penal. (Arboleda y Ruiz, 2002, p. 498)

\subsubsection{Sujeto pasivo}

También puede ser cualquier persona, no se requiere de una especial condición. Para Muñoz (2015): "será sujeto pasivo, todo el que tenga la voluntad abstracta o potencial de movimiento" (p.149). Para Pabón (2015), puede ser sujeto pasivo "cualquier ser humano vivo, imputable o inimputable" (p.170). Para Creus (1998):

En el secuestro extorsivo, el sujeto pasivo de esta particular extorsión es aquel a quien se le formula la exigencia de rescate. Es indiferente que el privado de libertad sea ese 


\section{Análisis Socio Jurídico del delito de secuestro en Colombia a partir de 1970}

mismo sujeto o un tercero. En este último caso, aunque la acción objetiva típica recae sobre el tercero, éste no adquiere carácter de sujeto pasivo, aunque se trata de un damnificado por el delito. También tiene este carácter el titular del patrimonio afectado cuando es una persona distinta de aquella a quien se le formula la exigencia, salvo que ella la haya recibido como un simple vehículo para que la exigencia llegue a la otra persona (p.ej., comunicar la exigencia al gerente del banco al que se quiere hacer pagar el rescate. (p.458)

De conformidad con lo normado, en el artículo 170 del Código Penal, el sujeto pasivo puede ser una persona discapacitada que no pueda valerse por sí misma o que padezca enfermedad grave, una persona menor de dieciocho (18) años o que no tenga la plena capacidad de autodeterminación, una mujer embarazada, un pariente hasta el cuarto grado de consanguinidad, cuarto de afinidad o primero civil, la cónyuge o compañera o compañero permanente y/o la persona que sea o haya sido periodista, dirigente comunitario, sindical, político, étnico o religioso en razón de ello o en persona internacionalmente protegida diferente a las señaladas en el título II de éste Libro y agentes diplomáticos, de conformidad con los Tratados y Convenios Internacionales ratificados por Colombia. (Arboleda y Ruiz, 2002, p.497)

En estos casos, tal como lo proponen Arboleda Vallejo y Ruiz Salazar, no se trata una modalidad de secuestro por su propia naturaleza, sino que la agravación obedece a consideraciones punitivas, por concurrir determinadas circunstancias. 


\subsubsection{Bien Jurídico}

Tal como se desprende de la ubicación del tipo penal de secuestro, detallado en el título III del Código Penal Colombiano denominado delitos contra la libertad individual y otras garantías, este es el bien jurídico protegido por la norma, coincide con ello la Sala Penal de la Corte Suprema de Justicia que destaca la vulneración de la libertad personal cuando ocurre la conducta de arrebatar, sustraer, retener u ocultar al agredido en un periodo de tiempo razonablemente prolongado para entender que se vulneró la libertad personal.(Corte Suprema de Justicia, 2012, M.P. Luis Guillermo Salazar Otero)

Tratando de definir lo que se entiende por libertad y su afectación como bien jurídico, se debe traer a colación en principio el concepto de Carrara (1889), para quien la libertad era un derecho natural que la sociedad se limitaba a reconocer y por consiguiente a proteger, consiste en la facultad constante que tienen los hombres para ejercer todas sus actividades, tanto morales como físicas en servicio de la satisfacción de sus propias necesidades, con la finalidad de alcanzar sus destinos en la vida terrenal. Así las cosas, en su Programa de Derecho Criminal señala que:

(...) la libertad humana no es otra cosa que la facultad de ejercitar la actividad propia sin lesionar los derechos de los demás; la libertad de uno debe coexistir con la libertad igual de todos. La restricción viene de la ley natural, que ha dado derechos a la humanidad e impuesto a los hombres la obligación de respetarlos. La ley humana no disminuye la libertad al contenerla dentro de los límites de su naturaleza. "Y más adelante agrega "El derecho penal, por el contrario, es protector de la libertad humana, no solamente externa sino también interna: de la libertad externa porque protege al débil contra el fuerte en el goce de sus derechos, dentro de los límites de la justicia, que es lo que constituye la verdadera libertad; de la libertad interna, porque da al 
Análisis Socio Jurídico del delito de secuestro en Colombia a partir de 1970

hombre una fuerza más para vencer a su peor tirano, las propias pasiones; y el hombre, como decía con razón Dagueseau, nunca es tan libre como cuando subordina sus pasiones a la razón, y la razón a la justicia. (Carrara, 1889, p.13)

Según Peña (2008), la libertad personal, después de la vida humana, constituye un bien jurídico de especial relevancia en una sociedad democrática, al constituirse en la plataforma esencial del individuo, para poder desarrollar a plenitud el resto de intereses jurídicos que le reconoce el ordenamiento jurídico. En efecto, la voluntariedad humana se manifiesta de forma concreta, en la capacidad de auto-locomoción, que importa el desplazamiento espacial y geográfico de una persona de acuerdo a su libre arbitrio; consustancial a la realización de una serie de actividades económicas, culturales y sociales. Para el mencionado autor, el atributo que tiene toda persona de desplazarse de un lugar a otro, en mérito a su espectro volitivo, por esa razón la ley se ampara una manifestación concreta de la libertad personal, la libertad externa, es decir, la libertad de movimientos en el espacio, ya que el atentado contra la libertad busca trabar tanto la libre locomoción como simplemente el libre movimiento corporal. (p. 451)

Para Bustos (1991), la concreción directa de los mandatos de un Estado de Derecho, es el reconocimiento de la libertad y de las garantías fundamentales, conditio sine quanon, para la participación del individuo en su ámbito de interactuación social y la realización de su personalidad. Por consiguiente, la libertad constituye la piedra angular del Sistema Jurídico-Estatal, que debe cautelarse con los instrumentos y mecanismos que prevé la Ley. Desde un aspecto negativo, importa el respeto de dicho bien jurídico, por parte del Estado y los particulares y, desde un aspecto positivo, determina la regulación de mecanismos legales, dirigidos a reponer un estado de cosas 
Análisis Socio Jurídico del delito de secuestro en Colombia a partir de 1970

de por si arbitrario e ilegal. Se dice, por tanto, que el bien jurídico tutelado por el tipo penal de Secuestro, es la libertad ambulatoria. (p.120)

Concretando cual es el bien jurídico tutelado en los delitos de secuestros y detenciones, como se había mencionado anteriormente, Muñoz (2015) asevera que:

En las detenciones ilegales y los secuestros inciden directamente en la libertad ambulatoria de las personas, aspecto más elemental y capital de la libertad humana, consistente en la capacidad de la persona de fijar por si misma su situación en el espacio físico, sin importar que a esa libertad externa no acompañe una libertad interna, el que concurra o no la facultad de discernimiento. (p. 148)

\subsubsection{Acción}

Diferentes autores han determinado cual es el concepto de acción en el delito de secuestro. Para Arboleda y Ruiz (2002) la acción consiste en:

Privar a alguno de la libertad personal. Por libertad debe entenderse en este caso la libertad espacial entendida como la libertad de movimiento en el espacio. De acuerdo con los citados autores, la acción puede cometerse por cualquier medio, con tal que sea idóneo, es decir que pueden ser medios directos como la coacción física (atar a la persona, encadenarla), la amenaza, la violencia y el engaño (sugestión hipnótica, propinar sustancias alcohólicas o estupefacientes) o indirectos, con los cuales se causa un efecto cual debe ser la privación de la libertad de locomoción por un tiempo más o menos largo , advirtiendo que el efecto típico de este delito es el encierro, sin importar que el lugar sea cerrado o abierto, público o privado. (p.496) 
Análisis Socio Jurídico del delito de secuestro en Colombia a partir de 1970

Para Peña (2008), Citando a Maurach:

El hecho recae aquí sobre la libertad física y en particular, la facultad de trasladarse de un lugar a otro, "de no poder alejarse de determinado lugar en que no se quiere permanecer". No es preciso que la víctima sea encerrada; el encierro sólo es un medio para cometer el delito, no previsto específicamente por la ley, quiere decir esto según el autor, que no necesariamente debe concretizarse un desplazamiento de un lugar a otro del sujeto pasivo por parte del sujeto activo. En consecuencia, una persona puede ser privada de libertad en su propia casa, en su dormitorio, lo que interesa en todo caso, es que la persona no pueda salir de un determinado espacio físico, que se encuentre retenida en contra de su voluntad, a pesar de que pueda realizar ciertos movimientos en un espacio geográfico reducido. Bajo tales presupuestos este supuesto, no se dará, claro está, en el caso de la denominada "detención domiciliaria". (p.459)

Muñoz (2015) afirma que:

La acción consiste en la privación al sujeto pasivo de la posibilidad de determinar por sí mismo su situación en el espacio físico, con indiferencia de las proporciones de este último, siendo las dos únicas modalidades típicas recogidas en el artículo 163-1 del Código Penal Español, el encierro y la detención, siendo indiferente el tipo de medios utilizados para ello o si se realizó por acción u omisión. El citado autor define la labor de encerrar como situar a una persona en un lugar no abierto, mueble o inmueble (automóvil, habitación, caravana etc.) y detener como equivalente a la aprehensión de una persona a la que se le priva de la facultad de alejarse en un espacio abierto (atándola, golpeándola, etc.). 
Análisis Socio Jurídico del delito de secuestro en Colombia a partir de 1970

Concluye Muñoz (2015) que: “en ambos casos el resultado es el mismo, privación de la libertad ambulatoria, con cuya realización se consuma el delito, aunque esta consumación pueda prolongarse luego indefinidamente" (p.149).

\subsection{Tipo Subjetivo}

En el análisis de la modalidad dogmática, se observa que el secuestro en cualquiera de sus modalidades es un delito normativa y materialmente doloso y en ningún caso culposo, en virtud que nuestro Estatuto Penal, adopta un sistema de "numerus clausus" en relación con la culpa, señalando en su artículo 21 que la culpa y la preterintención solo son punibles en los casos expresamente señalados en la ley, no estando incluido el secuestro en esa enumeración. El complemento subjetivo se amplía en forma ilimitada la finalidad específica abarcando cualquier fin perseguido por el agente diferente a los enunciados en el artículo 169 del Código Penal en el caso del secuestro simple y la ausencia de finalidad especifica en el secuestro extorsivo. (Pabón, 2015, p.170)

\subsection{Antijuridicidad}

Para Roxin (2010) “una conducta típica es antijurídica si no hay causas de justificación que excluya la antijuridicidad" (p.557).

En el mismo sentido una acción es formalmente antijurídica en la medida en que contraviene una prohibición o mandato legal; y es materialmente antijurídica en la medida en que en ella se plasma una lesión de bienes jurídicos socialmente nociva y 
Análisis Socio Jurídico del delito de secuestro en Colombia a partir de 1970

que no se puede combatir suficientemente con medios extra-penales. (Roxin, 2010, p.558)

De conformidad con estos criterios el juicio de contradicción material se da en la medida que esta conducta lesiona la libertad personal y de locomoción del sujeto pasivo. En cuanto a las causales de justificación admisibles en el secuestro simple están las de cumplimiento de un deber legal, orden legitima, ejercicio de un derecho, actividad lícita, cargo público y excepcionalmente el estado de necesidad. En el secuestro extorsivo, seria excepcionalmente admisible como causas de justificación, el cumplimiento de un deber y el estado de necesidad. (Pabón, 2015, p.171)

\subsection{Culpabilidad}

La ejecución de un hecho típico, antijurídico y no justificado, no es suficiente para aseverar la comisión de una conducta punible, en efecto es necesario que el agente haya actuado con culpabilidad. Dentro de la estructura dogmática adoptada por la Legislación Penal Colombiana desde 1980, la culpabilidad es el tercer elemento dogmático de toda conducta punible.

Al respecto, desde la década de los 80, la Sala Penal de la Corte Suprema de Justicia ha destacado:

Puede afirmarse que la culpabilidad es la actitud consciente de la voluntad que da lugar a un juicio negativo de reproche, porque el sujeto actúa antijurídicamente pudiendo y debiendo actuar de otra manera, y que en nuestro derecho positivo puede adoptar la forma del dolo, de la culpa o de la preterintención; cuando de la primera de ellas se trata, el agente mediante un acto de acción o de omisión emanado con humana libertad 
Análisis Socio Jurídico del delito de secuestro en Colombia a partir de 1970

de su propio psiquismo, realiza un hecho penalmente antijurídico con conocimiento de su típica ilicitud, con conciencia de su antijuridicidad y con voluntad de ejecutarla. (Corte Suprema de Justicia, Sentencia de 9 de agosto de 1983, M.P. Dr. Alfonso Reyes Echandía).

Doctrinalmente se han precisado tres elementos de la culpabilidad, el primero relacionado con la imputabilidad o capacidad de culpabilidad, entendido como la idoneidad o actitud jurídica de un sujeto para la realización plena de un hecho típico, antijurídico en cuanto culpable o reprochable, que genera como consecuencia jurídica la imposición de una sanción penal. El segundo es el conocimiento de la antijuridicidad en el cual al agente no se le exige que en el momento de su actuación conozca exactamente que su conducta está prohibida, sino que atendiendo a sus circunstancias personales, sociales, culturales, etc., haya tenido la oportunidad de tomar conciencia de dicha ilicitud y a pesar de ello a actuar y tercero la exigibilidad de comportamiento diferente, elemento que fija un ámbito normativo de conminación o un límite de exacción, que si bien se trata de nutrir estableciendo fronteras de naturaleza objetiva, sigue siendo un elemento por determinar frente al caso concreto. (Bustamante, 2011, p.1)

En este orden de ideas, para el caso del secuestro existen hechos que absuelven al sujeto en el juicio de reproche por cuanto destruyen el vínculo ético y psicológico que se requiere para la existencia del delito, estos pueden ser, en primer lugar por la inexigibilidad de comportamiento diferente (insuperable coacción ajena, miedo insuperable), en segundo lugar por incapacidad de culpabilidad (inimputabilidad por 
Análisis Socio Jurídico del delito de secuestro en Colombia a partir de 1970

trastorno mental) y en tercer lugar por falta de conocimiento de la antijuridicidad, excepcionalmente el error de prohibición. (Pabón, 2015, p.170)

\subsection{Formas de Ejecución y Consumación}

Doctrinariamente se ha establecido que el secuestro ya sea en la modalidad simple o extorsivo, se trata de un delito de resultado, por consiguiente, la perfección delictiva ha de fijarse desde el momento en que el sujeto pasivo pierde su libertad y se encuentra constreñido en su potestad locomotiva. En tal virtud, los actos de violencia y/o amenaza que el autor haya podido realizar sobre la víctima, pero sin éxito, en cuanto a su privación de libertad serán calificados como un delito tentado, las cuales podrán entrar en concurso con otras tipificaciones, si es que han provocado la afectación de otros bienes jurídicos; v.gr., si se afectó la integridad corporal del ofendido, con lesiones y, si se ingresó sin consentimiento de su titular a una vivienda, violación de domicilio.(Peña, 2008, p. 464)

Para el profesor Muñoz (2015):

El delito se consuma cuando se ha producido el resultado de privación de libertad. Cabe Pues la tentativa. Pero como la detención ilegal es un estado que puede prolongarse en el tiempo, estamos a veces ante un delito permanente, al igual que el de allanamiento de morada, en el que cabe una participación después de consumarse el delito, y cuya duración puede tener incidencia en la gravedad de la conducta. (Muñoz, 2015, p.151) 
Análisis Socio Jurídico del delito de secuestro en Colombia a partir de 1970

Al respecto la Corte Suprema de Justicia Sala Penal considera al secuestro como un delito de ejecución permanente, requiriendo para la comisión de este punible que el estado dañoso o de peligro, provenga de la conducta del sujeto activo de manera continua, es decir, que no se agote en un solo instante, sino que prosiga durante determinado tiempo, y que la prórroga de la situación antijurídica se deba a la exclusiva conducta voluntaria del sujeto, quien persiste en ella ininterrumpidamente después de la realización del hecho que constituye el inicio del punible. En este caso, el delito de secuestro inicia cuando la víctima es arrebatada, sustraída o retenida por otra persona, y culmina por razones materiales, cuando las autoridades consiguen su liberación, el plagiario desiste de continuar en su acción, escapa del control del secuestrador o fallece, o por razones jurídicas, cuando se clausura la fase instructiva, caso en el cual, el atentado a la libertad personal tiene lugar de manera constante y sin interrupción alguna durante todo el tiempo. (Corte Suprema de Justicia, 2010, M.P. María del Rosario González de Lemos)

En cuanto a la participación se encuentra que "en el delito de secuestro se admite la coautoría, determinación y complicidad” (Pabón, 2015, p.170). Por ejemplo el profesor Muñoz (2015) cita: “el caso de la persona que proporcionare el lugar destinado a la ejecución comisión del delito responde como cooperador necesario, aunque si existe acuerdo previo y división de funciones con los ejecutores de la detención puede ser considerado coautor” (p. 151). 
Análisis Socio Jurídico del delito de secuestro en Colombia a partir de 1970

\subsection{Tipos Privilegiados}

Para Muñoz (2015) son: "aquellas circunstancias en que se atenúa la pena del tipo básico" (p.152). Contrastando este postulado con el artículo 171 del código penal, estas se presentan si dentro de los quince (15) días siguientes al secuestro se dejare en libertad a la víctima, sin que se hubiere obtenido alguno de los fines previstos en el artículo $169 \mathrm{del} \mathrm{cp}$, la pena se disminuirá hasta en la mitad y en los casos de secuestro simple cuando el secuestrado dentro del mismo término fuere liberado.

\subsection{Tipos Cualificados}

Para Muñoz (2015) "son las razones por las que el legislador agrava la pena del tipo básico, creando una serie de tipos cualificados" (p. 152). Contrastando este postulado con el artículo 170 del Código Penal, estas circunstancias se pueden clasificar según la forma de ejecución del hecho, por los fines perseguidos, por la condición de la víctima y por el resultado.

1. Por la forma de ejecución del hecho, las circunstancias están previstas en el artículo 170 del c.p.p en los numerales 3 (si el secuestro se prolonga por más de 15 días), 5 (conducta realizada por miembro de fuerza pública o miembro fuerzas seguridad del Estado), 9 (afectación grave a los bienes actividad profesional o economía de la víctima),12 (utilización de orden de captura o detención falsa o simular tenerla), 13 (cuando se comete total o parcialmente desde lugar de privación de libertad), 14 (si se comete parcialmente en el extranjero) y 15 (cuando se trafique con la persona secuestrada). 
Análisis Socio Jurídico del delito de secuestro en Colombia a partir de 1970

2. Por los fines que persigue el agente, están descritas estas situaciones en el precitado artículo 170 del cpp numerales 7 (Cuando se cometa con fines terroristas), y 8 (Cuando se obtenga la utilidad, provecho o la finalidad perseguidos por los autores o partícipes).

3. Por la condición de la víctima, se pueden distinguir de la mencionada norma los numerales 1 (la conducta se comete en persona discapacitada, que padezca enfermedad grave, menor de dieciocho (18) años, o en mayor de sesenta y cinco (65) años, o que no tenga la plena capacidad de autodeterminación o que sea mujer embarazada) 4 ( si se ejecuta en parientes cercanos, persona integrada a la unidad doméstica o sobre quien se tenga un grado de confianza), 11 ( $\mathrm{Si}$ se comete en persona que sea o haya sido periodista, dirigente comunitario, Defensor de Derechos Humanos, miembro de una organización sindical legalmente reconocida, política, étnica o religiosa o en razón de ello y 16 (si se comete en persona internacionalmente protegida).

4. Por el resultado, se pueden distinguir en el artículo 170 del cpp, los numerales 2 (Si se somete a la víctima a tortura física o moral o a violencia sexual durante el tiempo que permanezca secuestrada), 6 (Cuando se presione la entrega o verificación de lo exigido con amenaza de muerte o lesión o con ejecutar acto que implique grave peligro común o grave perjuicio a la comunidad o a la salud pública) y 10 (Cuando por causa o con ocasión del secuestro le sobrevengan a la víctima la muerte o lesiones personales). (Pabón, 2015, p. 172) 


\subsection{Punibilidad}

La punibilidad debe ser idónea para la prevención, es decir debe ser adecuada para inhibir las conductas prohibidas en el tipo correspondiente, pero su función - que es el aspecto más importante- es la protección de bienes jurídicos a través, precisamente de la prevención general, por tal razón la punibilidad debe ser proporcional al bien jurídico tutelado. (Jiménez e Islas, 2002, p.60)

Sobre el aumento genérico de penas, puntualmente del que fue objeto el delito de secuestro a través de la reforma aplicada a través del artículo 14 de la Ley 890 de 2004, la Corte Suprema de Justicia únicamente encuentra justificación en la concesión de rebajas de pena por la vía de los allanamientos o preacuerdos, regulados en la Ley 906 de 2004.

Para la Sala Penal las disminuciones de pena a las que se llegaría por la aplicación de tales mecanismos de justicia premial justificaron que el legislador, desde la óptica del principio de proporcionalidad, ajustara los límites punitivos a fin de mantener la consonancia entre la gravedad de los delitos y las consecuentes penas, conforme a lo estimado a la hora de expedir el Código Penal y sus respectivas reforma. (Corte Suprema de Justicia, 2013, M.P. José Leónidas Bustos Martínez)

La Honorable Corte Constitucional, al declarar la exequibilidad del incremento punitivo elaborado a través del art. 14 de la Ley 890 de 2004, declaró que se ajusta a la Constitución pues habiendo examinado los antecedentes de la Ley, encuentra que, en su momento, en el concreto ejercicio de fijación de las sanciones punitivas el legislador estaba dentro de la cláusula general de competencia legislativa que le atribuyen los artículos 114 y 150 de la Carta, lo cual incluye por supuesto, la facultad de legislar sobre cuestiones penales y penitenciarias además que el aumento 
Análisis Socio Jurídico del delito de secuestro en Colombia a partir de 1970

de penas la Corte lo encuentra justificado en la necesidad de la medida en términos de política criminal, con respeto a los límites dictados por el principio de proporcionalidad. (Corte Constitucional, Sentencia C-238/05, M.P. Jaime Araujo Rentería)

La siguiente tabla muestra las penas actuales de los tipos penales estudiados con los aumentos reseñados anteriormente:

Tabla 1. Penas Actuales - Aumentos reseñados

\begin{tabular}{|c|c|c|}
\hline$\overline{\text { Tipo Penal }}$ & $\overline{\text { Articulo }}$ & Penas Establecidas \\
\hline Secuestro simple & $\begin{array}{l}168 \text { Ley } 599 \text { de } 2000 \\
\text { modificado por el artículo } \\
1 \text { Ley } 733 \text { de } 2002 \text { y por } \\
\text { el artículo } 14 \text { Ley } 890 \text { de } \\
2004 .\end{array}$ & $\begin{array}{l}\text { Ley } 599 \text { de } 2000 \text { prisión modificado por el } \\
\text { art } 1 \text { Ley } 7332002 \text { prisión de } 144-240 \\
\text { meses y multa de } 600 \text { a } 1000 \text { smlmv. } \\
\text { Según aumento Ley } 890 \text { de } 2004 \text { art } 14 \\
\text { prisión de } 192 \text { a } 360 \text { meses y multa de } 800 \\
\text { a } 1500 \text { smlmv }\end{array}$ \\
\hline $\begin{array}{l}\text { Secuestro } \\
\text { extorsivo }\end{array}$ & $\begin{array}{l}169 \text { Ley } 599 \text { de } 2000 \\
\text { modificado por el artículo } \\
2 \text { Ley } 7332002 \text { y art } 1 \\
\text { Ley } 1200 \text { de } 2008 .\end{array}$ & $\begin{array}{l}\text { Prisión de } 320 \text { a } 504 \text { meses y multa de } \\
2666.66 \text { a } 6000 \text { smlmv. }\end{array}$ \\
\hline $\begin{array}{l}\text { Circunstancias de } \\
\text { agravación para } \\
\text { el secuestro } \\
\text { extorsivo }\end{array}$ & $\begin{array}{l}170 \text { Ley } 599 \text { de } 2000 \\
\text { modificado por el artículo } \\
3 \text { Ley } 7332002 \text { y art } 14 \\
\text { Ley } 890 \text { de } 2004 \text {. }\end{array}$ & $\begin{array}{l}\text { Ley } 599 \text { de } 2000 \text { prisión modificado por el } \\
\text { art } 3 \text { Ley } 7332002 \text { La pena señalada para } \\
\text { el secuestro extorsivo será de } 28 \text { a } 40 \text { años } \\
\text { y multa de } 5000 \text { a } 50000 \text { smlmv. } \\
\text { Según aumento ley } 890 \text { de } 2004 \text { art } 14 \\
\text { prisión de } 448 \text { a } 600 \text { meses y multa de } \\
6666.66 \text { a } 50000 \text { smlmv. }\end{array}$ \\
\hline
\end{tabular}

Fuente: Código Penal Colombiano, 2016. Elaboración propia.

\subsection{Subrogados Y Beneficios}

Para hablar de épocas recientes, la Legislación Colombiana ha tenido una palpable tendencia a la restricción en el tema de concesión de beneficios y subrogados a las 
Análisis Socio Jurídico del delito de secuestro en Colombia a partir de 1970

personas investigadas como posibles responsables de la comisión del delito de secuestro. Se puede citar la ley 733 de 2002 que fuera dictada al amparo de los Códigos Penal y de Procedimiento Penal expedidos en el año 2000, y la cual en su artículo 11 estableció una serie de prohibiciones para los procesados por delitos de terrorismo, secuestro, secuestro extorsivo y extorsión, quienes bajo esa disposición no podrían disfrutar de rebajas de pena por sentencia anticipada y confesión, suspensión condicional de la ejecución de la pena, libertad condicional, prisión domiciliaria, ni ningún otro beneficio o subrogado legal, judicial o administrativo, excepto los beneficios por colaboración previstos en el estatuto procesal. De esa manera, se modificaron parcialmente los artículos 38, 63 y 64 del Código Penal y 40, 283, 357 parágrafo, 480, 481 y 494 del Código de Procedimiento Penal, en el sentido de entender incluida la prohibición en cada uno de sus textos. En materia de libertad condicional, los artículos 64 de la Ley 599 de 2000 y 11 de la Ley 733 de 2004, conforman en materia de libertad condicional la proposición jurídica completa.

En efecto, las dos disposiciones regulaban de manera integral la materia y por tanto, al disponer el artículo 5 de la Ley 890 de 2004, que la libertad condicional procede para todos los delitos, derogó en conjunto las disposiciones anteriores (que luego fueran instituidas mediante la Ley 1121 de 2006). Así las cosas a partir de la expedición de la Ley 890 de 2004, vigente a partir del 1 de enero de 2005, se derogó tácitamente el 64 de la Ley 599 de 2000, modificado por la Ley 733 de 2002, en lo que tiene que ver con los presupuestos relacionados con la libertad condicional, de tal forma que los condenados que antes estaban excluidos de la posibilidad de acceder a la libertad condicional por la naturaleza del delito que ejecutaron, ahora la tienen, siempre que se 
Análisis Socio Jurídico del delito de secuestro en Colombia a partir de 1970

cumplan y se superen las exigencias normativamente previstas, esto es, la valoración acerca de la gravedad de la conducta, el cumplimiento de la dos terceras partes de la pena y que su conducta en el establecimiento carcelario permita deducir que no existe necesidad de continuar con la ejecución de la pena.

Con relación a otras prohibiciones como la de acceder a la sentencia anticipada, señala la Sala Penal que deben examinarse en concreto y respetando el instituto específico de que se trata, advirtiendo que por virtud del principio de favorabilidad es aplicable el artículo 5 de la Primera Ley, en tanto genera mayores posibilidades de acceder a la libertad condicional, las cuales no se pueden rehusar con argumentos de competencia, que en nada inciden tratándose de una reforma eminentemente sustancial. Agregando respecto de la suspensión condicional de la ejecución de la pena y de la prisión domiciliaria, la posibilidad de ser acordadas a través de las negociaciones que realicen fiscalía e imputado, convenios que obligan al juez excepto si son lesivos de las garantías fundamentales, no admite exclusiones por la naturaleza del delito a menos que se exprese en contrario una inequívoca voluntad legislativa manifestada a través de una ley que se expida en la nueva y transformada realidad del Sistema Procesal Penal.

Fue precisamente la iniciativa legislativa que se materializó en la Ley 1121 de 2006 por la cual se dictan normas para la prevención, detección, investigación y sanción de la financiación del terrorismo y otras disposiciones, la que en su artículo 26 vuelve a traer a la legislación penal la exclusión de beneficios y subrogados, advirtiendo que cuando se trate de delitos de terrorismo, financiación de terrorismo, secuestro extorsivo, extorsión y conexos, no procederán las rebajas de pena por sentencia 
Análisis Socio Jurídico del delito de secuestro en Colombia a partir de 1970

anticipada y confesión, ni se concederán subrogados penales o mecanismos sustitutivos de la pena privativa de la libertad de condena de ejecución condicional o suspensión condicional de ejecución de la pena, o libertad condicional. Tampoco a la prisión domiciliaria como sustitutiva de la prisión, ni habrá lugar ningún otro beneficio o subrogado legal, judicial o administrativo, salvo los beneficios por colaboración consagrados en el Código de Procedimiento Penal, siempre que esta sea eficaz. (Congreso de la República de Colombia, Ley 1121 de 2006, Diario oficial №. 46.497)

La ley en mención específicamente su artículo 26 fue analizada y declarada exequible por la Honorable Corte Constitucional en sentencia c 073 de 2010, arguyendo que en materia de concesión de beneficios penales, el legislador cuenta con amplio margen de configuración normativa, en tanto que es una manifestación de su competencia para fijar la política criminal del Estado, las medidas legislativas mediante las cuales se restringe la concesión de beneficios penales en casos de delitos considerados particularmente graves para la sociedad se ajustan a la constitución y además que el Estado Colombiano ha asumido compromisos internacionales en materia de combate contra el terrorismo, razón de más para que el legislador limite la concesión de beneficios penales en la materia. (Corte Constitucional, Sentencia C-073/10, M.P. Humberto Antonio Sierra Porto). 
Análisis Socio Jurídico del delito de secuestro en Colombia a partir de 1970

\section{Capítulo IV. Reseña histórica del secuestro en Colombia}

\subsection{Características del secuestro y principales actores}

Desde comienzos del siglo XX se ha tenido noticia de la práctica del secuestro en nuestro país, en efecto tenemos como uno de los primeros casos inscritos en medios de comunicación, lo que se denominó en ese entonces como el "rapto" a la niña Elsa Eder, acaecido a las 11:30 de la mañana del 31 de enero de 1933 al oeste de Cali. Para el momento se habla de "rapto", pero no se utiliza el término secuestro por cuanto esta conducta para la fecha no estaba tipificada en el ordenamiento penal colombiano. "Sólo en 1936 en el Código Penal, aparece la tipificación de éste” (Rubio, 2003, p. 3)

De acuerdo con lo registrado, un carro azul de cuatro puertas frenó en seco justo en la orilla del río Aguacatal en el valle del Cauca, donde la niña, junto a su niñera y sus dos perros, jugaba tranquilamente; bajándose del vehículo un hombre bien vestido, que con tono acelerado le dijo a la niñera que la madre de la menor lo mandó a recogerla, porque era necesario tomarle unas fotografías para una importante revista, a lo cual ella le creyó y la dejo ir con el sujeto. Horas después una persona identificada como Luis Escobar realizó una visita a la casa de los Zawadzky familia influyente de Cali, para avisar que la pequeña Elisa se encontraba en una pensión de la carrera séptima con calle 21, al llegar las autoridades al sitio señalado por Escobar, estaban allí cuatro mujeres, un hombre y Elisa, logrando rescatarla.

Posteriormente el 20 de marzo de 1965, fue secuestrado el padre de la niña que había sido objeto de rapto en 1933; en efecto, Harold Eder era un prominente industrial vallecaucano, propietario del ingenio azucarero La Manuelita y ex ministro de Estado, para ese entonces contaba 
Análisis Socio Jurídico del delito de secuestro en Colombia a partir de 1970

con 62 años de edad fue secuestrado en su hacienda Quebradaseca, en Corinto (Cauca). A pesar de que la Tercera Brigada del Ejército creó un grupo élite para su rescate, el cuerpo de Eder apareció un mes más tarde en una tumba que se construyó en una capilla de su compañía. La dimensión política de esta acción se confirmó con la atribución de su responsabilidad "al grupo comandado por Manuel Marulanda Vélez (alias, Tirofijo), del cual surgirán un año más tarde, las FARC" (Rubio, 2003:5).

En la medida que se intensificaba en Colombia la práctica del secuestro, en el continente americano sucedían hechos que es importante contextualizar:

En primer lugar, encontramos que emerge en Cuba, antes del triunfo de la revolución, la llamada "la fiebre de secuestros de aviones" que se da cuando los pilotos civiles cubanos se niegan a transportar armas para el Ejército Cubano, del Presidente Batista, además de que se les traslade a la Fuerza Aérea y lo que es más impactante, a continuar volando sobre la zona dominada por los rebeldes, pues éstos le disparan a las aeronaves.

El primer apoderamiento de aeronave en Cuba, ocurre el 9 de Abril de 1958, cuando un C-46, con 4 tripulantes pidieron asilo al Gobierno de USA en Miami, luego de aterrizar allí; para esta fecha había un total de 26 aviadores esperando asilo. El 13 de Abril de 1958, se produce el segundo apoderamiento, esgrimiendo los pilotos las mismas causas que el anterior caso, ésta vez había 3 tripulantes que pidieron asilo en Miami y 12 pasajeros del avión un DC-3 de Cubana de Aviación que cubría la ruta la Habana a Santa Clara. Posteriormente, el 1 de Noviembre de 1958, el Movimiento 26 de Julio, de Fidel Castro, secuestra otra aeronave con 20 personas a bordo, en ruta Miami - Habana - Varadero, un Viscount-755, el avión es desviado a Oriente por la 
Análisis Socio Jurídico del delito de secuestro en Colombia a partir de 1970

Provincia de Holguín, y el 5 de Noviembre de 1958, los revolucionarios vuelven a operar y secuestran un DC-3 de Cubana (vuelo 482) piloteado por Armando Piedra, que cubría la ruta Manzanillo a Holguín. A bordo había 25 pasajeros y 3 tripulantes. El avión aterriza en la zona rebelde. (Urribarres, 2000, párr., 2)

En segundo lugar, a mediados del siglo XX específicamente en los años 60, surgen en Latinoamérica movimientos guerrilleros reivindicatorios identificados con la revolución cubana de 1959, es así como surge el movimiento de los denominados tupamaros en Uruguay, el Frente Farabundo Martí para la Liberación Nacional (FMLN) en El salvador, la Unión Revolucionaria Nacional Guatemalteca (URNG) en Guatemala, el Frente Sandinista de Liberación Nacional (FSLN) y la Unión patriótica y el movimiento 19 de abril en Colombia. (Chato, 2016)

En tercer lugar, los grupos de izquierda de la República Argentina denominados montoneros, utilizan la retención de personas con fines económicos y políticos, justificándola como el "cobro forzoso de un impuesto por una autoridad paralela"; en el mismo sentido en Colombia durante la década de los 70, los grupos subversivos empezaron a secuestrar diplomáticos y empleados de multinacionales con exigencias económicas hasta llegar a cifras millonarias en divisas. (Rubio, 2003)

En la década de los 80, en Colombia se hace claro el uso político y económico del secuestro con la "espectacular" toma por parte del M-19 de la Embajada de República Dominicana en Bogotá (27 febrero de 1980), con catorce embajadores como rehenes. En dicha ocasión los guerrilleros exigen liberar más de 300 guerrilleros prisioneros, cuestión que termina el 27 de abril cuando el comando del M-19 se dirige hacia Cuba llevando como garantía a doce (12) de los rehenes que sólo serían liberados en La Habana. En la actualidad, un fenómeno no conocido en épocas 
Análisis Socio Jurídico del delito de secuestro en Colombia a partir de 1970

anteriores ha hecho presencia en la segunda parte de la década final del siglo XX y en los años iniciales del siglo XXI: integrantes de la fuerza pública también han sido secuestrados "en pocas incursiones la guerrilla se llevó quinientos (500) uniformados, de ellos trescientos siete (307) policías entre 1998 y 2002” (Vizcaíno, 2004, p.14).

Al respecto, el Centro Nacional de Memoria Histórica destaca que los secuestros realizados por el M-19 en los años setenta y ochenta del siglo XX, tenían como objetivo desestabilizar y presionar al Estado; lo mismo sucedió con los secuestros realizados por el narcotráfico a finales de los años ochenta e inicio de la década de los noventa, con los cuales buscaba negociar su entrega y frenar la extradición. De igual manera, las FARC, al retener a cientos de policías y militares, buscó un "canje humanitario" con los presos de su organización; y el ELN, cuando se han dado escenarios de diálogos de paz, aumenta el número de secuestros para "mejorar" su posición en la negociación. (Centro Nacional de Memoria Histórica, 2013, p. 28)

De acuerdo con el estudio realizado por el movimiento internacional IKV PAX CHRISTI, lo anterior resultó ser sólo el inicio del periodo que estaba por llegar en nuestro país en materia de secuestro, así es como en Colombia entre los años de 1995 y 2001, se vivió un verdadera golpe de secuestros, que registra una cifra de 3.706 casos de secuestro registrados en el año 2000. (Centro Nacional de Memoria Histórica, 2013)

Este fuerte aumento en el número de secuestros en este periodo fue, principalmente, el resultado de las denominadas pescas milagrosas, casos en los que los secuestradores, específicamente guerrilleros, secuestraban indiscriminadamente a turistas y personas que viajaban por las carreteras nacionales. En dicha actividad, los lugares escogidos 
Análisis Socio Jurídico del delito de secuestro en Colombia a partir de 1970

eran previamente estudiados, las víctimas se identificaban de acuerdo al tipo de vehículo en el cual se movilizan y, en varios casos, sobre todo en los delitos cometidos por las guerrillas, se habla del uso de computadores en los cuales se comparan los números de cédulas de las personas retenidas con una base de datos. (Centro Nacional de Memoria Histórica, 2013, p.50)

Por otra parte, entre los años de 2001 y 2005 registró el mayor número de secuestros por parte de los grupos paramilitares. Esto está relacionado, en primer lugar, con la perpetración de secuestros políticos para presionar al gobierno nacional y exigirle una negociación política (como en efecto sucedió en el año 2005 con la expedición de la ley de justicia y paz) y en segundo lugar, para ejercer presión política y posicionar a sus candidatos en la contienda electoral de 2002. (Centro Nacional de Memoria Histórica, 2013)

En el periodo comprendido entre los años 2006-2010 aparecieron las redes criminales dedicadas al secuestro, en lo que mal se denominan “atribuidos a la delincuencia común”, organizaciones que en su mayoría tenía un modus operandi netamente urbano que generó aún mayor concentración de los secuestros en las ciudades, haciéndose tan especializadas estas redes en la comisión de estos delitos que incluso, los principiantes son vinculados inicialmente a tareas de apoyo logístico, y al aumentar su confianza dentro del grupo, pasan a ser responsables del cuidado de las víctimas. Por su parte, los elementos más especializados son quienes realizan el "levante", la negociación con las familias, y el recibo y administración de los recursos. (Centro Nacional de Memoria Histórica, 2013)

Según el Centro Nacional de Memoria Histórica (2013) en un hecho de secuestro puede existir concurrencia de diversos actores, es así como se han documentado casos en los que las 
Análisis Socio Jurídico del delito de secuestro en Colombia a partir de 1970

guerrillas subcontratan el secuestro de sus víctimas, en los cuales ellos entregan la información del objetivo y las redes criminales ponen en marcha su conocimiento y experiencia para hacer el "levante", la estabilización y el traslado de los plagiados hasta la entrega a su nuevo captor, representando ello sin duda un alto grado de especialización de la industria.

En efecto, resulta evidente que a lo largo de estos años ha existido diversidad tanto en las causas como en los actores del fenómeno del secuestro tal como se puede sintetizar en el siguiente gráfico.

Gráfica 2. Participación de los actores del secuestro

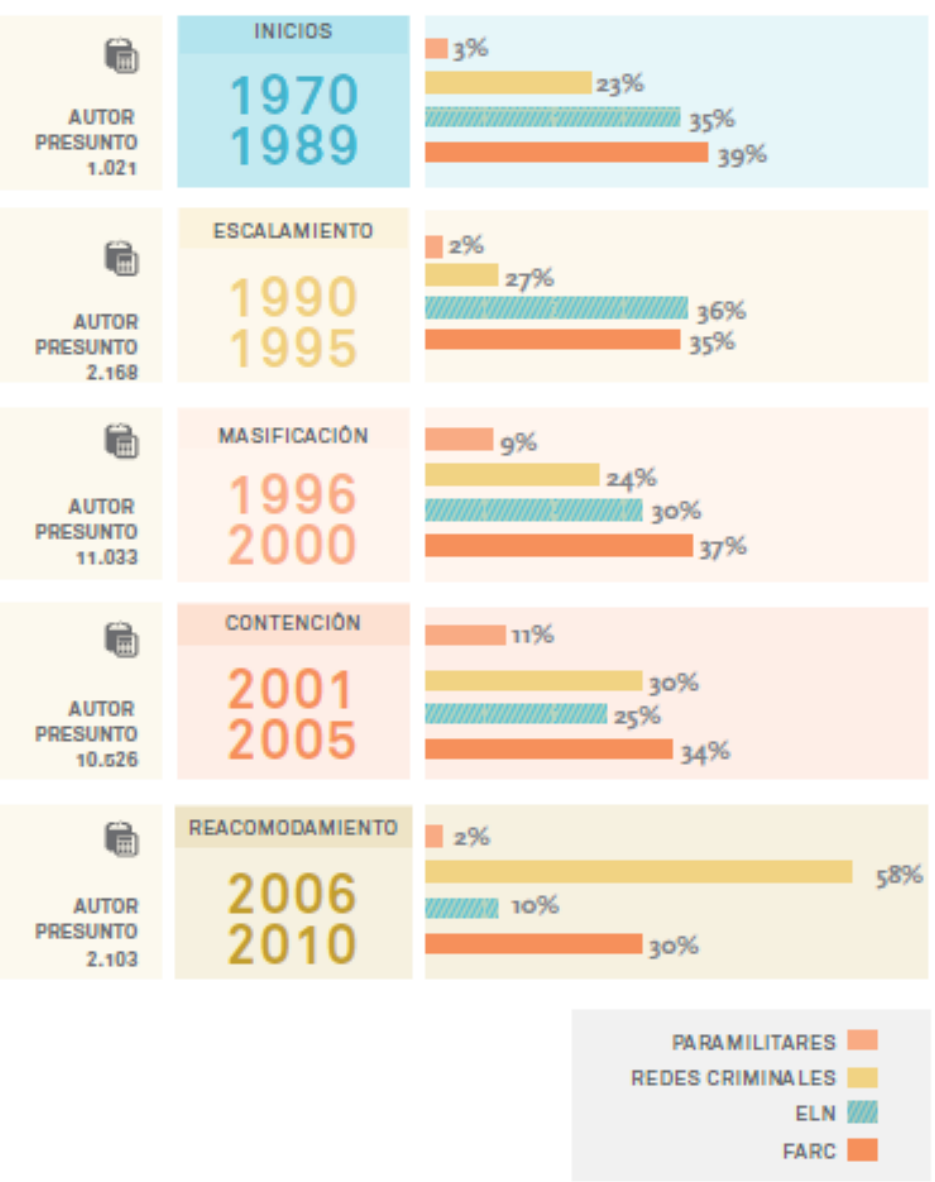

Fuente: Centro Nacional de Memoria Histórica, 2013 
Análisis Socio Jurídico del delito de secuestro en Colombia a partir de 1970

\subsection{El secuestro en la sociedad Colombiana}

En las décadas de los 80 y 90 especialmente, el secuestro coexistía en la sociedad colombiana, siendo percibido a veces de forma indolente por ella, hasta que alguno de los casos afectaban a su familia o a miembros de un hogar allegado, lo cual no era extraño ya que desafortunadamente era de común ocurrencia en las ciudades y recaía sobre personas de altos ingresos económicos o incluso con medianas ganancias en sus negocios, todo con el propósito de obtener rescate, o de una manera efectiva, causar daño o perjuicio a la persona privada de la libertad o a otra persona relacionada con aquélla.

Las cifras recopiladas por el CNMH ( una verdad secuestrada pag 48) dejan ver la intensidad del fenómeno y en efecto se asegura que un $84 \%$ de los secuestros perpetrados entre 1970 y 2010 fueron extorsivos, en los cuales se pretende obtener algún tipo de provecho económico a cambio de la liberación de la persona plagiada, dejando en la sociedad vestigios nefastos como la sensación de vulnerabilidad, de inseguridad, aumento de la desconfianza en los demás y la familia tiende a encerrarse en sí misma manteniendo con el entorno una relación temerosa y llena de zozobra. Las personas sienten que no tienen control sobre lo que les pueda suceder, la confianza se vuelve selectiva reduciendo al máximo el círculo de personas consideradas fiables, hay una gran sensación de desesperanza y pérdida de interés por un país que se ha convertido en fuente constante de temor.

Al ser el secuestro un fenómeno de violencia socio - política, moviliza a las familias afectadas por este flagelo a cuestionar la situación social actual. En efecto se genera desencanto en el país, sumado a una sensación de temor constante mantenida por la presencia del secuestro y otros hechos violentos, por las constantes amenazas y la 
Análisis Socio Jurídico del delito de secuestro en Colombia a partir de 1970

ejecución de las mismas a quienes intentan influir sobre la situación y por la polarización social, generan la sensación de impotencia frente a la violencia que aqueja actualmente a Colombia. En consecuencia, el secuestro no sólo afecta a los individuos y a las familias en su funcionamiento íntimo sino sus relaciones con el contexto social. En este sentido, consideramos que la presencia constante del secuestro va minando sutilmente la red de relaciones sociales, al romper las bases sobre las cuales se fundamenta. Nos obliga a centrarnos en lo privado viendo lo público y al país como algo de lo cual hay que protegerse y defenderse. $\mathrm{Y}$ en este proceso de defensa las víctimas se sienten absolutamente solas, desamparadas por un Estado incapaz de protegerlas, e impotentes frente a una situación que perciben como externa a ellas y sobre la cual no pueden tener injerencia alguna. (Navia y Ossa, 2001, párr., 29)

La sociedad civil se ha movilizado de manera activa contra el secuestro, es así como los ciudadanos, por su parte, también han reaccionado por medio de manifestaciones en contra del delito y sus autores más visibles: las guerrillas. Estas manifestaciones han contado con la presencia de millares de colombianos y han obtenido un gran despliegue mediático y se ven reflejadas en las manos y en las voces de ese grupo de organizaciones instauradas desde la sociedad civil, que con coraje se han enfrentado de manera directa al fenómeno y han trabajado por varios años para posicionar y mantener viva la problemática en la agenda nacional e internacional. En ese orden de ideas, surgen organizaciones sociales como la Fundación País Libre, Asfamipaz con el claro objetivo de acompañar a las víctimas de este flagelo, de mostrarles a quienes lo han padecido que no están solos, y es por esto que se han constituido como símbolos contra el secuestro en el país. (Centro Nacional de Memoria Histórica, 2013) 
Análisis Socio Jurídico del delito de secuestro en Colombia a partir de 1970

En desarrollo de esta lucha en contra del secuestro, la sociedad civil organizo gran cantidad de actividades y manifestaciones públicas cuyo objetivo era visibilizar a las víctimas del secuestro ante los antes gubernamentales y no gubernamentales tanto a nivel nacional como internacional, a continuación relacionaremos algunas de las más representativas.

Cuadro 1. Actividades y manifestaciones públicas por el secuestro

\begin{tabular}{|c|c|c|}
\hline Fecha & $\begin{array}{c}\text { Nombre } \\
\text { Movimiento } \\
\end{array}$ & Objeto \\
\hline $\begin{array}{c}\text { Nov-Dic } \\
1996\end{array}$ & $\begin{array}{l}\text { Por el país que } \\
\text { queremos, } \\
\text { NO AL } \\
\text { SECUESTRO. }\end{array}$ & $\begin{array}{l}\text { Pretendía sembrar la semilla de la sociedad civil movilizándola, } \\
\text { con fundamento en que los actores en conflicto razonan y } \\
\text { deciden actuar solo cuando sienten que la opinión pública ya } \\
\text { no les cree, ya no se los aguantan más y está dispuesta a salir a } \\
\text { la calle. Buscaba que la reacción del ciudadano no fuera } \\
\text { meramente en el sillón de la sala, desde un coctel, desde el } \\
\text { restaurante o desde la charla en el corredor de la empresa, sino } \\
\text { que se requería pasar de la indiferencia a la acción. (El Tiempo, } \\
\text { 1996, párr., 3) }\end{array}$ \\
\hline $\begin{array}{c}26 \text { de } \\
\text { Octubre } \\
\text { de } 1997\end{array}$ & $\begin{array}{l}1997 \text { Mandato } \\
\text { Ciudadano por } \\
\text { la Paz, la Vida } \\
\text { y la Libertad. }\end{array}$ & $\begin{array}{l}\text { En el contexto de escalamiento de la guerra, creciente } \\
\text { afectación de la población civil, y dificultades para avanzar en } \\
\text { la solución política negociada, cerca de diez millones de } \\
\text { colombianos, consagraron con su voto el Mandato Ciudadano } \\
\text { por la Paz, la Vida y la Libertad el } 26 \text { de octubre de } 1997 \text { - } \\
\text { durante las elecciones locales-, en virtud del cual se } \\
\text { comprometieron a ser constructores de "Paz y Justicia Social, a } \\
\text { proteger la vida y a rechazar toda acción violenta" y a exigir a } \\
\text { los actores del conflicto cesar la guerra y respetar las normas } \\
\text { del derecho internacional humanitario. El resultado visible del } \\
\text { Mandato Ciudadano por la paz, fue la instalación de la Mesa de } \\
\text { diálogo y negociación entre el Gobierno Nacional y la guerrilla } \\
\text { de las FARC en enero de 1999. (INDEPAZ, 2009, párr., 3) }\end{array}$ \\
\hline $\begin{array}{l}\text { Junio- } \\
\text { Octubre } \\
\text { de } 1999\end{array}$ & ¡NO MÀS! & $\begin{array}{l}\text { En junio de } 1999 \text { llevó a cabo su primera gran marcha en Cali, } \\
\text { para protestar por un secuestro masivo llevado a cabo por el } \\
\text { grupo guerrillero ELN el } 30 \text { de mayo de 1999, en la iglesia La } \\
\text { María de esa ciudad. De ahí en adelante se realizaron marchas } \\
\text { en otras veintiuna ciudades de Colombia. }\end{array}$ \\
\hline
\end{tabular}




\begin{tabular}{|c|c|c|}
\hline Fecha & $\begin{array}{c}\text { Nombre } \\
\text { Movimiento }\end{array}$ & Objeto \\
\hline & & $\begin{array}{l}\text { En octubre de 1999, el movimiento NO MÁS convocó a la } \\
\text { Primera Gran Marcha Nacional por la Paz, hasta ese momento } \\
\text { la más importante movilización ciudadana que se había } \\
\text { registrado en Colombia. Doce millones de personas } \\
\text { manifestaron en todas las capitales del país, en cerca de } \\
\text { setecientos municipios y en cincuenta y ocho ciudades del } \\
\text { exterior para exigir a los grupos guerrilleros un cese al fuego, } \\
\text { la negociación sin interrupción y la exclusión de los civiles del } \\
\text { conflicto. (El Tiempo, 2000) }\end{array}$ \\
\hline 2004 & $\begin{array}{l}\text { Un clamor por } \\
\text { la libertad de } \\
\text { todos los } \\
\text { secuestrados }\end{array}$ & $\begin{array}{l}\text { Organizada por la Fundación País Libre incluyo una a maratón } \\
\text { radiofónica ininterrumpida de } 110 \text { horas por la liberación de los } \\
\text { secuestrados en Colombia, en la cual se logró con la dirección } \\
\text { del periodista HERBIN HOYOS enlazar } 2.610 \text { emisoras } \\
\text { radiales, leyendo más de } 12.000 \text { mensajes de familiares y otras } \\
\text { personas en solidaridad con los secuestrados, lo cual fue } \\
\text { difundido igualmente a través de las redes sociales. (Revista } \\
\text { Semana, 2007) }\end{array}$ \\
\hline $\begin{array}{c}4 \text { de } \\
\text { Febrero } \\
\text { de } 2008\end{array}$ & $\begin{array}{l}\text { Un millón de } \\
\text { voces contra } \\
\text { las FARC } \\
\text { COLOMBIA } \\
\text { SOY YO }\end{array}$ & $\begin{array}{l}\text { Fueron varias movilizaciones cívicas en distintos lugares del } \\
\text { mundo bajo el eslogan "Colombia soy yo" que sucedieron el } 4 \\
\text { de febrero de } 2008 \text { en las que se protestó contra las acciones de } \\
\text { las FARC. Estas movilizaciones surgieron en enero de } 2008 \\
\text { desde la red social Facebook como reacción a la situación de } \\
\text { los secuestrados evidenciada en las pruebas de supervivencia } \\
\text { entregadas por el grupo guerrillero en diciembre de } 2007 \text { y al } \\
\text { fracaso de la operación Emanuel, relacionada con la entrega del } \\
\text { menor hijo de la entonces secuestrada CLARA ROJAS. Por el } \\
\text { carácter novedoso del surgimiento del evento, algunos analistas } \\
\text { políticos percibían que del mismo surgiría alguna clase de } \\
\text { movimiento cívico también de largo aliento, con el paso de los } \\
\text { meses esas percepciones fueron desmentidas. (El Tiempo, } \\
\text { 2008, párr.., 3) }\end{array}$ \\
\hline
\end{tabular}

Fuente: Elaboración propia, 2017 
Figura 4. Marcha por el país que queremos. No al secuestro.
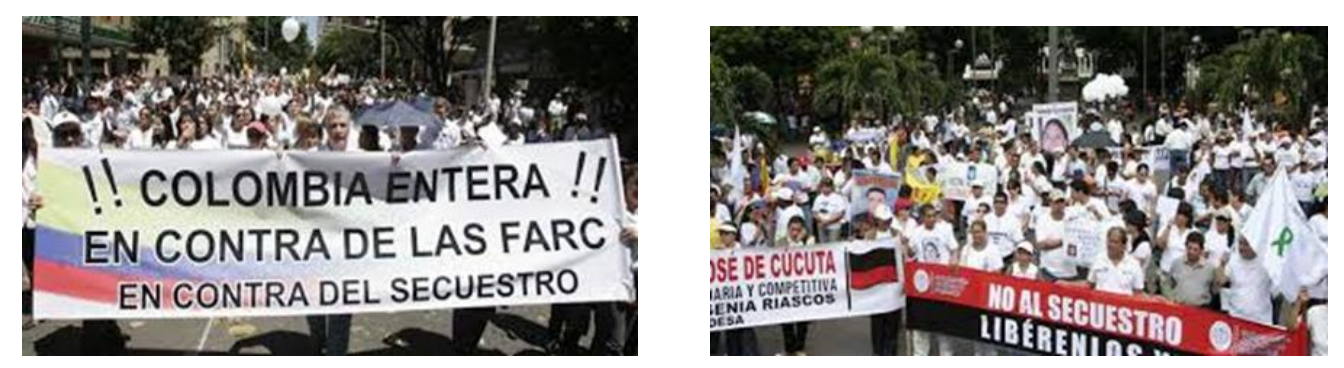

Fuente: Wikipedia, 2011.

Figura 5. Mandato ciudadano por la Paz, la Vida y la Liberta

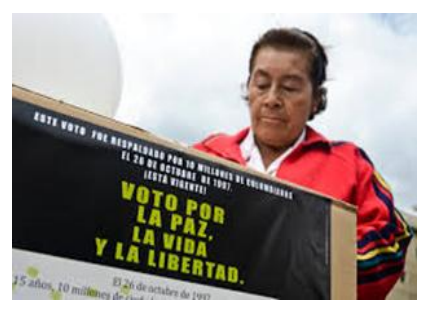

Fuente: Lasdosorillas.co, 2017

Figura 6. Marcha movimiento NO MÁS
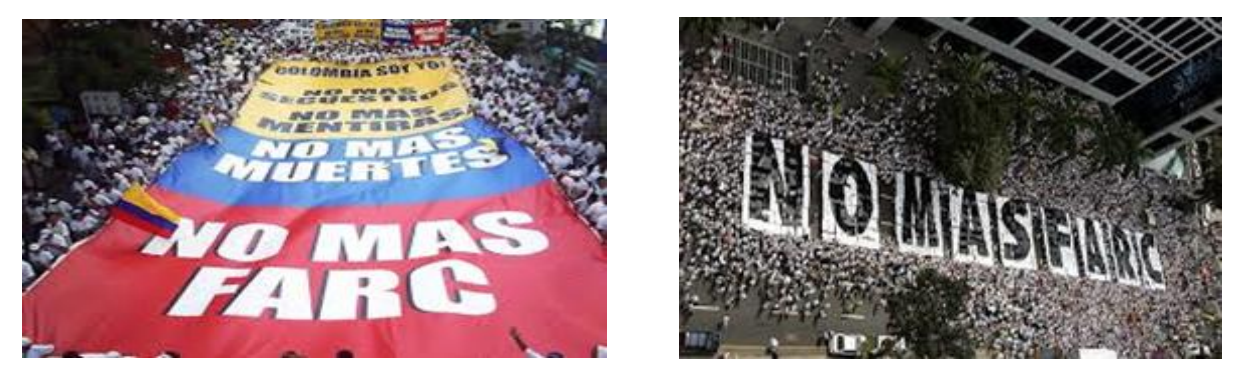

Fuente: El país, 2008 
Figura 7. Un millón de voces contra las FARC también llamada la marcha del 4 de febrero
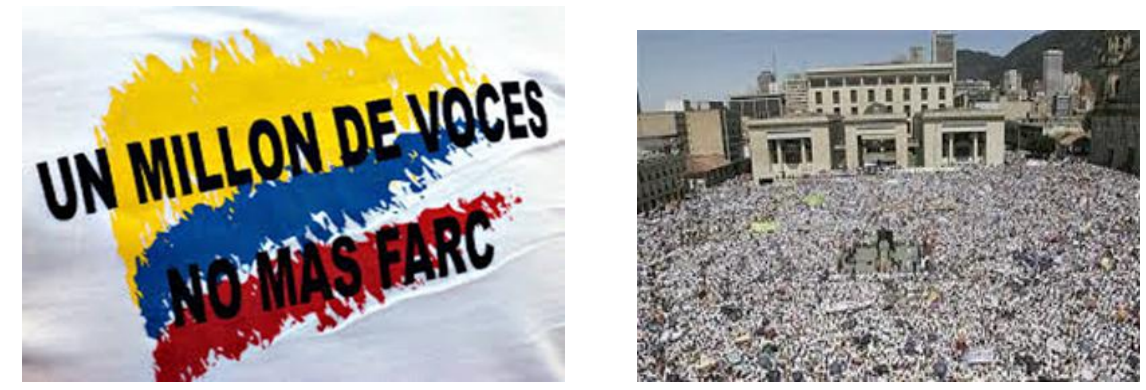

Fuente: Flickr, 2017

\subsection{Vestigios del secuestro}

\subsubsection{Secuelas psicológicas de la víctima.}

La experiencia del secuestro tiene características muy particulares y dependen de múltiples factores entre ellos hay que tener en cuenta: Los autores del secuestro, tipo de secuestro, tiempo de cautiverio, condiciones alimenticias, sanitarias y emocionales brindadas por los victimarios durante el cautiverio. Fortalezas y recursos psicológicos previos del cautivo (recursos intelectuales, valores, creencias, estrategias para resolver conflictos, autoestima, proyecciones hacia el futuro, entre otros); la edad, la presencia de experiencias traumáticas, el lugar y rol que ocupe el secuestrado dentro del núcleo familiar, circunstancias vitales en las que se encuentra tanto la persona como la familia antes del secuestro y las redes de apoyo afectivo y social con que cuente el individuo y la familia. (País Libre, 1995, párr., 1)

Se afirma que durante el período de cautiverio, el miedo a morir, se convierte en un fantasma permanente, la víctima se ve afectado por un temor que lo acompaña independientemente del trato recibido por los secuestradores, y sigue presente aún 
Análisis Socio Jurídico del delito de secuestro en Colombia a partir de 1970

después de haber sido liberado. Este temor, está relacionado con el hecho que en la mayoría de los casos, la persona no está preparada para enfrentar amenazas reiteradas de muerte, ni situaciones extremas de violencia o de guerra. Entonces se asume que se trata de una experiencia brusca que por lo general se presenta de forma imprevista originando un daño psíquico por el fuerte impacto de dicha experiencia, la herida no sólo es de carácter orgánico sino funcional, en el que la persona empieza a padecer trastornos en su funcionamiento normal, en sus pensamientos o en sus emociones, conductas o en sus capacidades. (Quintero, Rodríguez y Vera 1995, párr., 2)

En consecuencia, al verse la victima sometida al maltrato psicológico ocasionado con esta conducta delictiva y las consecuentes circunstancias degradantes físicas y ambientales del lugar, se hace vulnerable a problemas de salud, que aún permanecen después de la liberación. También se puede presentar el maltrato psicológico por medio de reiteradas amenazas de muerte, lenguaje soez, simulacros del asesinato de la víctima, la manipulación de los estados emocionales del plagiado y la vigilancia permanente; también se da con desinformación sobre el desarrollo de las negociaciones y sobre el conocimiento que tienen sobre la vida familiar del secuestrado, produciendo en el retenido sentimientos de impotencia y sumisión. (País Libre, 1995)

Se ha encontrado que en muchos casos, que los procesos de pensamiento tienden a paralizarse respecto a lo que sucede en el entorno, el ordenamiento de ideas y la selección de respuestas posibles para ejecutar en un momento dado se sustituyen por impulsos gobernados por el miedo y el terror, no reaccionando o con la ejecución de respuestas automáticas y caóticas, que arriesgan la vida y la integridad física. Sin embargo, puede presentarse casos en los cuales la persona plagiada tiene algún entrenamiento en enfrentar situaciones de alto riesgo o similares, u otros recursos que 
Análisis Socio Jurídico del delito de secuestro en Colombia a partir de 1970

le ayudan a conservar alguna capacidad de seguir pensando a través del miedo, ordenar ideas y actuar en consecuencia. (Meluk, 1998, párr., 4)

Así mismo, el hecho de que la persona está imposibilitada para establecer relaciones afectivas fiables con quienes lo rodean, lo obligan a establecer una relación con su mundo interno, con sus recuerdos y con las vivencias del pasado de una manera casi permanente durante el cautiverio. De esta forma, las personas hacen un examen de su vida pasada, una reevaluación de sus relaciones familiares y sociales donde se recrea y reinterpreta su historia.

Para enfrentar esta situación, la persona pone en marcha recursos psicológicos particulares que permiten tener algún grado de control sobre sí mismo y sobre el entorno, estos mecanismos pueden relacionarse con la utilización de sus vivencias, experiencias, creencias y conocimientos, que de una u otra forma le ayudan a sobrevivir, ya sea modificando la situación o haciéndola psicológicamente más soportables; la adquisición de creencias religiosas o afianzarlas en caso de que ya las tuvieran. (Rodríguez y Camacho, 2000, párr., 7)

La utilización de estrategias de control del tiempo ligado al manejo del ocio y a la inactividad de la víctima, que. Esto permite tener la sensación de que el tiempo avanza, de que hay un orden externo y psicológico durante el cautiverio y de los sentimientos de esperanza relacionados con el hecho de que todo terminará y que finalmente se sobrevivirá a la situación. (Meluk, 1998, párr., 8)

Las personas que se han visto sometidas a este tipo de situaciones comienzan a presentar algunos síntomas específicos como la evitación de estímulos o situaciones 
Análisis Socio Jurídico del delito de secuestro en Colombia a partir de 1970

asociadas al acontecimiento traumático e intento deliberado para evitar los pensamientos o sentimientos que puedan provocar ese recuerdo; distanciamiento de las demás personas y pérdida de interés por actividades que anteriormente resultaban atractivas, y también de la capacidad de sentir emociones como la intimidad o ternura; reexperimentación del suceso traumático, lo que hace que el individuo tenga que luchar contra pensamientos de tipo recurrente, repetitivo, o sueños angustiantes; síntomas de incremento de la activación emocional, con dificultades para concentrarse, hipervigilancia, trastornos del sueño, entre otros.

Se ha señalado por la doctrina que la víctima del secuestro puede ser afectado con el denominado trastorno estrés postraumático dentro del cual puede presentar estados de depresión, ansiedad u otros trastornos comportamentales dentro de los cuales las personas suelen manifestar reacciones emocionales dolorosas, tristeza, ira, ansiedad; pueden manifestar síntomas de regresión y dependencia, aislamiento o incremento de la apatía. (Quintero, Rodríguez y Vera 1995, párr., 11)

En otros casos puede presentarse el denominado Síndrome del Sobreviviente, la tríada típica compuesta por cefaleas frecuentes, pesadillas recurrentes y estados de tristeza más o menos periódicos y otra manifestación anímica que puede darse, también posterior a la liberación, es una euforia desmesurada, que produce la sensación en la persona liberada de querer aprovechar la vida de mejor manera, de recuperar tiempo perdido. Esta etapa "(...) es también un espacio de negación de la realidad, de todos los padecimientos del cautiverio y de las dificultades y contradicciones de la vida familiar y laboral. Por lo tanto, en este lapso las huellas dejadas por el secuestro no se manifiestan" (Meluk, 1998, párr., 14) 
Análisis Socio Jurídico del delito de secuestro en Colombia a partir de 1970

\subsubsection{Afectación a la familia y entorno de la victima}

El secuestro como fenómeno no sólo afecta dramáticamente al secuestrado, sino también a su familia y a sus allegados. Incluso, luego de la liberación, los efectos producidos en la víctima y su familia, hacen que permanezcan mentalmente encadenados y alejados de la libertad, pues el miedo, el temor y la inseguridad les generan una disminución en su capacidad de socialización, como por ejemplo transportarse a un lugar visitado antiguamente. (Centro Nacional de Memoria Histórica, 2013, p. 103)

Aunque generalmente tendemos a centrar nuestra atención sobre el secuestrado y a considerar que él o ella son quienes deben recibir ayuda para superar esa experiencia traumática, cuando ocurre un secuestro éste afecta sicológicamente a familiares y secuestrados por igual, y en todo análisis del impacto debe tenerse siempre en cuenta a esas otras víctimas nunca contempladas en las cifras estadísticas. Estudios recientes muestran que el impacto psicológico del trauma no puede reducirse a quienes lo viven directamente; sus consecuencias, constructivas y patológicas, se extienden hacia el medio social inmediato, familia y allegados, así como hacia aquellas personas dedicadas a trabajar con este tipo de población. (Navia, 2001, párr., 4)

Durante el secuestro, la familia no se encuentra retenida entre paredes ni tampoco tiene un arma enfrente, sin embargo se encuentra encerrada y amenazada psicológicamente por un secuestrador que se deja sentir y perpetúa su presencia con cada llamada telefónica, en efecto la familia no sabe dónde están ni en qué momento les pueden sorprender. (Esguerra, 2011, párr., 59) 
Análisis Socio Jurídico del delito de secuestro en Colombia a partir de 1970

Esto sin olvidar que las familias tienen que enfrentar, además del secuestro de uno de sus integrantes, las pérdidas que derivan de este evento como las deudas, menores ingresos o la reubicación de la residencia, entre otros, que pueden contribuir al surgimiento de diversos conflictos en la persona secuestrada, en los integrantes de la familia y/o en la familia como sistema. (Dirección General de Sanidad Militar, 2010)

Así las cosas, el secuestro tiene un efecto de bomba expansiva que invade el entorno familiar y social, los cuales pueden verse afectados en mayor o menor medida, puesto que el impacto que los sucesos estresores tienen en las personas, depende de factores previos a la victimización, así como de los que ocurren durante y posteriormente a la misma. (Medina, Lara, Ramos, Zambrano y Fleiz, 2005, p. 8)

En consecuencia, sin duda se pueda catalogar al secuestro como un evento traumático, en tanto que es una experiencia inesperada que amenaza la integridad física del individuo, que desafía las formas habituales de manejo del entorno y genera una respuesta emocional de temor, desesperanza y horror. Durante el cautiverio, la persona retenida y su familia son expuestas al trauma crónico infligido por un captor que busca someter a sus víctimas mediante el ejercicio de un control despótico sobre todos los aspectos de sus vidas. (Navia y Ossa, 2000)

Lo anterior se puede reflejar en estudio realizado para el año 2003, con familias víctimas del delito de secuestro en el departamento de Antioquia, los resultados de dicho análisis arrojan que el secuestro fue considerado por las familias como un ultraje a dos derechos fundamentales del ser humano: la vida y la libertad. No obstante, movilizó sus potencialidades de forma que no permitieron su derrumbamiento ni en desintegración, ni en conflicto, y demostraron su fuerte resiliencia familiar. En segundo lugar el secuestro fue considerado como una pérdida ambigua, y 
Análisis Socio Jurídico del delito de secuestro en Colombia a partir de 1970

así lo asumieron las familias, definiéndolo como la experiencia más dura y llena de incertidumbre, que puede vivir una persona y en otro caso como una pausa en el tiempo, una castración de ideales y de metas, una incertidumbre y una angustia al no saber qué pasaría en el futuro. (Molina, Agudelo, Ríos, Builes, Ospina, Arroyave López Jaramillo, Vásquez y Navia, 2003)

Estas consecuencias, indican que el secuestro va desestructurando sutilmente la red de relaciones sociales, haciendo que la vida de la víctima y de su entorno centre su vida en lo privado, viendo lo público y al país como algo de lo cual hay que protegerse y defenderse. En este proceso de defensa las víctimas se sienten absolutamente solas, desamparadas por un Estado incapaz de protegerlas y ofrecer soluciones para combatir la violencia que nos acosa diariamente y se nos hace cada vez más presente. De otro lado, las familias se ven enfrentadas a una montaña rusa de emociones cuando se genera la expectativa de que su familiar será liberado y las autoridades anuncian las liberaciones de secuestrados pero, cuando pasa el tiempo luego de las liberaciones, y no se sabe de acciones concretas de las autoridades ni se logra tener información del paradero de sus seres queridos, la rabia, la desconfianza y la desesperanza son una constante en su vida. Después de cada liberación parece que se reduce el espacio de las demás familias que esperan a sus seres queridos secuestrados y de los que nadie habla, pues a partir de las últimas liberaciones las familias piensan que con cada liberación se reduce el espacio de interlocución con el Gobierno nacional y con los mismos medios de comunicación. (Navia y Ossa, 2000, párr., 10)

Mientras algunas familias pueden "seguir con sus vidas" en términos de seguir con su proyecto de vida a nivel económico y laboral a pesar de su dolor constante, otras familias presentan en algunos de sus miembros el desánimo, la falta de metas y el apego a la esperanza de que su ser querido regresará en cualquier momento. Además, la búsqueda de ayuda se produce luego de meses o incluso años de la desaparición o 
Análisis Socio Jurídico del delito de secuestro en Colombia a partir de 1970

el secuestro de su familiar cuando el impacto psicológico ha comenzado a generar otras dificultades, particularmente la depresión (Agudelo, 2000, p. 20).

No obstante todo lo negativo que implica un suceso de estos en el entorno familiar, en algunos casos, al percibir la muerte cercana pero luego tener una segunda oportunidad, las familias reevalúan su escala de valores y cambian las prioridades que tenían antes. Se aumenta el valor dado a la vida, a la libertad, a la espiritualidad y al amor de la familia y de otra parte se le resta relevancia al dinero y al trabajo. En segundo término, las relaciones de pareja se tornan más cooperativas, sea por el exitoso desempeño de la mujer en varias áreas o porque el esposo que regresa asume un rol más activo generando una mayor simetría en la relación marital. Igualmente la familia refuerza metas tales como el bienestar de los hijos, la paz, la tranquilidad y el fortalecimiento de valores espirituales. (País Libre, 2011, p. 32)

\subsubsection{El Secuestro: Un Trauma Psicosocial}

El conflicto en Colombia es distinto de otras guerras civiles en el mundo que suelen tener causas étnicas, económicas o religiosas claras. En efecto, habiéndose convertido en un Caleidoscopio de factores históricos y sociales, este enfrentamiento es casi imposible de resumir con palabras, incluso para los colombianos es un reto definir la naturaleza de la guerra y existe una variedad de interpretaciones, ya que muchos creen que la guerra se ha convertido en un lucrativo negocio que se auto perpetúa, corrompido en su totalidad por el narcotráfico, otros la ven como un ciclo de represalias por las atrocidades cometidas en el pasado; otra vuelta de la rueda vengativa 
Análisis Socio Jurídico del delito de secuestro en Colombia a partir de 1970

que gira de generación en generación, y otros argumentan que es una guerra de clases entre campesinos revolucionarios que enfrentan a un sistema corrupto. (Sthepen, 2012, p.1)

Como se ha venido arguyendo a lo largo de este trabajo, se puede asegurar que el secuestro barbarizó la guerra en Colombia, ya que no ha sido un fenómeno adjetivo sino sustantivo del conflicto que afecta nuestro país. Recordemos que a partir de los años 70, y especialmente de los años 80 , este fenómeno delictual fue reivindicado por las guerrillas como un instrumento de guerra contra una minoría opulenta y poderosa o corrupta, procediendo luego a no sólo en contra de los pudientes sino también a los pobres, a los ciudadanos del común pero también a los políticos y funcionarios de todas las jerarquías. Luego en virtud a la degradación de la guerra el secuestro rompió la línea de diferenciación de los actores armados con la delincuencia común, siendo utilizada por la guerrilla para evadir la autoría de los secuestros y el consiguiente repudio público, entrelazamiento que disparó la ocurrencia del secuestro y lo hizo cada vez más oprobioso. (Centro de Memoria Histórica, 2013, p. 14)

Es evidente que la existencia de la guerra o conflicto interno como generador de hechos perturbadores, ha afectado de manera negativa a la sociedad por cuanto ha implantado cambios nocivos en ella. De todo esto nace lo que ha sido definido por Ignacio Martín-Baró como trauma psicosocial, concepto que surgió del análisis de las relaciones perturbadas por la guerra que, en esos momentos, tenía lugar en el Salvador y cómo éstas afectaban a cada individuo. En ese escenario surge esta concepción referida como se ha dicho, al importante impacto que tiene el hecho perturbador, en este caso la guerra, sobre la sociedad y como este se cristaliza en cada persona, porque hay que aclarar que este trauma no produce un efecto uniforme o común a toda la sociedad, sino que este efecto dependerá de la vivencia particular de cada individuo. 
Análisis Socio Jurídico del delito de secuestro en Colombia a partir de 1970

Dentro de un contexto general para todas las sociedades, ha sido definido el trauma psicosocial como algún proceso histórico que puede haber dejado afectada a toda una población, la traumatiza, en el sentido de que sus relaciones sociales se encuentran perturbadas, lo que se expresa en procesos psicosociales que tienden a la instauración de la desconfianza, la rigidez, el escepticismo y la violencia como forma de resolución de conflictos. Cabe mencionar, dos aspectos que deben tenerse en cuenta al momento de referirse respecto al trauma psicosocial: primero, que la herida que afecta a cada persona ha sido producida en conjunto, o sea, socialmente, por lo tanto sus raíces no se encuentran en un solo individuo sino que en su sociedad; segundo, que su sustento lo encuentra en la relación entre en individuo y la sociedad a través de diversas mediaciones institucionales, grupales e incluso individuales. (Baro, 1989, p. 9)

Los efectos que se generan a raíz del secuestro varían enormemente y dependen de cómo vive la experiencia cada persona; por ejemplo los niños pueden ser más susceptibles a trastornos psicológicos como consecuencia del cautiverio. El tiempo en que la víctima se encuentre en cautiverio he incluso las condiciones en las que el secuestrado se mantiene determina enormemente el efecto que tendrá. Si se habla de carácter dialectico del trauma de psicosocial es para subrayar que la herida o la afectación dependerá de la peculiar vivencia de cada individuo, condicionada por su vivencia social, por su grado de participación en el conflicto. (Baro, 1989, p. 8)

En el análisis de los efectos del secuestro en la sociedad colombiana sea lo primero advertir que aunque en el país aún se sigue cometiendo este delito, son las cifras oficiales las que permiten evidenciar que en los últimos 17 años ha decrecido ostensiblemente su ocurrencia, es por ejemplo que se puede afirmar que en el 2016 se reportaron 199 secuestros, mientras que en el 2017 ocurrieron 190, lo que muestra una disminución del 94 por ciento si se compara esta cifra con los 3.572 casos denunciados en el año 2000. (El Tiempo, 2017) 
Análisis Socio Jurídico del delito de secuestro en Colombia a partir de 1970

Ahora bien, siendo un hecho evidente esta mengua, también lo es que la sociedad Colombiana en estas décadas ha venido siendo testigo y víctima de hechos que causan dolor, frustración, sufrimiento, tristeza, impotencia e incluso enojo, lo que permite aseverar que ha permanecido ante un constante trauma psicosocial que se puede circunscribir en lo que Baró definió como trauma psicosocial cuando se refería "A la vivencia o experiencia que afecta de tal manera a la persona (...) si se utiliza el término de trauma es porque se entiende que este residuo es negativo, que se trata de una herida, de una huella desfavorable para la vida de la persona" (Martín-Baró, 1989, p. 8)

Se debe anotar igualmente que el secuestro, en especial el cometido por los grupos armados al margen de la ley que para esa época y aun en el caso del ELN se encontraban en conflicto con el Estado Colombiano, se ha venido esgrimiendo como arma utilizada para ejercer presión política en el marco de esta guerra. En ese tenor, el trauma psicosocial generado por la guerra y dentro de ella los factores perturbadores como el secuestro, acarrean un proceso de deshumanización, entendido como el empobrecimiento de cuatro importantes capacidades del ser humano: a) su capacidad de pensar lúcidamente b) su capacidad de comunicarse con veracidad c) su sensibilidad frente al sufrimiento ajeno d) su esperanza. (Samayoa, 1987, p. 461)

Ignacio Martín Baró reconoce 3 ejes, de los cuales se podría dar la razón por la que una sociedad padezca un trauma psicosocial: como primera instancia se tiene "la violencia, que orienta los mejores recursos de cada contendiente a la destrucción de su rival; como segunda esta la polarización social, que corresponde al desplazamiento de los grupos hacia extremos opuestos, con el consiguiente endurecimiento de sus respectivas posiciones ideológicas y la presión sobre las diversas instancias sociales para que los otros se adhieran a su posición y por último la mentira institucional, que va desde la desnaturalización del objeto hasta el ocultamiento ideológico de la 
Análisis Socio Jurídico del delito de secuestro en Colombia a partir de 1970

realidad social". Para el autor, la prolongación indefinida de estos factores perturbadores originados en la guerra como el secuestro, supone la normalización de este tipo de relaciones sociales deshumanizantes ocasionando un debilitamiento de la personalidad que no encuentra la posibilidad de afirmar con autenticidad su propia identidad, a la vez que las personas van a asumir como connatural el desprecio por la vida humana, la ley del más fuerte como criterio social y la corrupción como estilo de vida, precipitando así un grave círculo vicioso que tiende a perpetuar la guerra tanto objetiva como subjetivamente. Por ello, para Baró es necesario trabajar por establecer un nuevo marco para la convivencia, un nuevo "contrato social" en el mejor de los sentidos que permita la interacción colectiva sin que la discrepancia se convierta en negación mutua; hay que trabajar por un sinceramiento social, que lleve a conocer las realidades antes de definirlas, a aceptar los hechos antes de interpretarlos; hay, finalmente, que esforzarse por educar en la razón y no en la fuerza, de manera que la convivencia se funde en la complementariedad mutua para resolver los problemas y no en la violencia para imponer la propia alternativa. (Baró, 1990, p. 13)

En conclusión, los efectos psicológicos que ocasiona la vivencia constante del secuestro en nuestra sociedad sugieren la presencia de un trauma psicosocial que se mantiene y alimenta en la relación entre el individuo y la colectividad que constantemente se va deteriorando, es así como la sociedad colombiana ha venido siendo afectada por el miedo generalizado, la desesperanza, la sensación de impotencia frente a lo que acontece y la tendencia a aceptar pasivamente lo que sucede a nuestro alrededor, lo cual adquiere más relevancia en aquellos traumas que surgen como expresión de la violencia socio política de un país, que aunque no se encuentra tan acentuada como en los años 90 o inicios del siglo 21, desafortunadamente aún se padece actualmente en Colombia. (Ossa, 2001) 
Análisis Socio Jurídico del delito de secuestro en Colombia a partir de 1970

En estudio realizado por Navia y Ossa, se concluyó que para la mayoría de las familias, el secuestro no es un hecho puntual que se presenta, causa un daño y desaparece. Su presencia constante en la sociedad, la exposición continua a través de los medios de comunicación y la posibilidad siempre presente de que vuelva a ocurrir a pesar de las medidas de seguridad que se tomen, son factores que dificultan la superación de la experiencia y la posibilidad de ganar de nuevo una sensación de control y manejo. Por otro lado, además de tener que enfrentar el trauma, las familias se ven abocadas a confrontar las pérdidas que éste generó: deudas, menores ingresos y desplazamiento del lugar de residencia buscando un sitio seguro, tanto dentro como fuera del país. Esto convierte al secuestro en una experiencia compleja enmarcada dentro un contexto socopolítico que no ofrece los elementos de seguridad, confianza y apoyo necesarios para superarla adecuadamente, por el contrario, lo que observamos diariamente a través de los medios de comunicación, de las experiencias de nosotros y de quienes nos rodean, es la ratificación constante de la impotencia de la sociedad civil ante el conflicto armado. (Ossa, 2001)

Por lo anterior, se puede afirmar que somos una sociedad traumatizada dentro de un contexto que perpetúa y mantiene la situación, una situación que, por su misma reiteración, va perdiendo la calidad de imprevista y fuera de lo común para tornarse en algo "normal”, común, esperado y con lo cual nos vamos acostumbrando a vivir. Por ello, tal como concluye el citado estudio, se ha venido requiriendo y aun es necesario, ampliar nuestra mirada buscando comprender los efectos del secuestro en la relación de individuo con la sociedad ya que la percepción de este caos frente al que no se ven posibilidades de salida, el temor y la confusión que produce, alteran la capacidad de pensar racionalmente sobre la situación y nos colocan en una posición de defensa constante más que de acción y de construcción. (Ossa, 2001) 


\subsubsection{Algunos casos relevantes.}

La siguiente es una cronología de algunos de los secuestros con fines políticos perpetrados por las Farc y del desenlace de algunos casos:

Cuadro 2. Cronología de algunos secuestros con fines políticos

\begin{tabular}{||l|l||}
\hline \multicolumn{1}{|c|}{ FECHA } & \multicolumn{1}{|c|}{ CASO } \\
\hline \hline $\mathbf{1 9 9 6} 30$ de agosto & $\begin{array}{l}\text { Guerrilleros atacan la base militar de "Las Delicias", en la } \\
\text { Amazonía, donde matan a 27 militares y secuestran a 60 que son } \\
\text { liberados meses después. }\end{array}$ \\
\hline \hline $\mathbf{1 9 9 7}$ \\
21 diciembre & $\begin{array}{l}\text { Las FARC atacan una base del Ejército en el Cerro de Patascoy, } \\
\text { suroeste, mueren 10 militares y 18 son secuestrados. }\end{array}$ \\
\hline \hline $\mathbf{1 9 9 8}$ \\
3 de marzo & $\begin{array}{l}\text { Un ataque en El Billar (Caquetá) deja 65 militares muertos y 43 } \\
\text { secuestrados. }\end{array}$ \\
\hline \hline 3 de agosto & $\begin{array}{l}\text { Las FARC atacan una base antinarcóticos en Miraflores } \\
\text { (Guaviare), matan a 40 policías y militares y secuestran a 56. }\end{array}$ \\
\hline \hline 1 noviembre & $\begin{array}{l}\text { La guerrilla ocupa Mitú, capital del departamento de Vaupés, } \\
\text { mueren 16 policías y militares y 61 son secuestrados. }\end{array}$ \\
\hline \hline $\mathbf{1 9 9 9}$ \\
7 de enero & $\begin{array}{l}\text { Las FARC negocian con el presidente Andrés Pastrana (1998- } \\
\text { 2002) en una zona de distensión (desmilitarizada) de más de } \\
\text { 43.000 kilómetros cuadrados en el sur del país. }\end{array}$ \\
\hline \hline 25 de febrero & $\begin{array}{l}\text { Tres indigenistas estadounidenses son secuestrados en la frontera } \\
\text { con Venezuela y días después aparecen muertos. }\end{array}$ \\
\hline \hline $\begin{array}{l}\mathbf{2 0 0 0} \\
5 \text { de agosto }\end{array}$ & Secuestrado el representante a la Cámara Óscar Tulio Lizcano. \\
\hline \hline 4 diciembre & $\begin{array}{l}\text { El ex ministro de Desarrollo Fernando Araujo, es secuestrado en } \\
\text { Cartagena. }\end{array}$ \\
\hline \hline \begin{tabular}{l}
$\mathbf{2 0 0 1} 10$ de junio \\
\hline 15 de julio
\end{tabular} & $\begin{array}{l}\text { Secuestrado el senador Luis Eladio Pérez Bonilla en el } \\
\text { departamento de Nariño. }\end{array}$ \\
\hline \hline 26 de julio & $\begin{array}{l}\text { El ex gobernador Alan Jara es secuestrado cuando viajaba en un } \\
\text { vehículo de la ONU. }\end{array}$ \\
\hline $\begin{array}{l}\text { Laj FARC asaltan un edificio en Neiva y secuestran a los dos } \\
\text { doce vecinos. El 27 de febrero de 2003, las FARC entregan a }\end{array}$ \\
\hline
\end{tabular}




\begin{tabular}{|c|c|}
\hline FECHA & CASO \\
\hline & $\begin{array}{l}\text { delegados de Chávez y de la Cruz Roja Internacional a los ex } \\
\text { congresistas cautivos Gloria Polanco de Lozada, al igual que a } \\
\text { Orlando Beltrán Cuéllar, Luis Eladio Pérez y Jorge Eduardo } \\
\text { Géchem Turbay. }\end{array}$ \\
\hline 28 de agosto & $\begin{array}{l}\text { El congresista Orlando Beltrán Cuéllar es secuestrado en el } \\
\text { departamento del Huila. }\end{array}$ \\
\hline $\begin{array}{l}10 \text { de } \\
\text { septiembre }\end{array}$ & $\begin{array}{l}\text { Secuestrada en el Huila la congresista Consuelo González de } \\
\text { Perdomo. }\end{array}$ \\
\hline $\begin{array}{l}29 \text { de } \\
\text { septiembre }\end{array}$ & $\begin{array}{l}\text { Muere en una operación de rescate la ministra de Cultura, } \\
\text { Consuelo Araujo, secuestrada días antes cerca de la Sierra Nevada } \\
\text { de Santa Marta. }\end{array}$ \\
\hline $\begin{array}{l}2002 \\
20 \text { de febrero }\end{array}$ & $\begin{array}{l}\text { Guerrilleros obligan al piloto de un avión a aterrizar en una } \\
\text { carretera del Huila y secuestran a tres ocupantes, entre ellos el } \\
\text { senador Jorge Eduardo Gechem Turbay, lo que provoca la ruptura } \\
\text { de los diálogos de paz. }\end{array}$ \\
\hline 23 de febrero & $\begin{array}{l}\text { La candidata presidencial Ingrid Betancourt, también nacional } \\
\text { francesa, y su compañera de fórmula, Clara Rojas, son } \\
\text { secuestradas. El } 10 \text { de enero de 2008, Clara Rojas y Consuelo } \\
\text { González de Perdomo fueron entregadas por las FARC a una } \\
\text { comisión enviada por el presidente venezolano, Hugo Chávez, a } \\
\text { territorio colombiano. }\end{array}$ \\
\hline 21 de abril & $\begin{array}{l}\text { Secuestrados y asesinados el gobernador de Antioquia, Guillermo } \\
\text { Gaviria, y su asesor de paz, Gilberto Echeverri. }\end{array}$ \\
\hline 11 de abril & $\begin{array}{l}\text { Las FARC asaltan la Asamblea Departamental del Valle del } \\
\text { Cauca en Cali y secuestran a doce diputados. }\end{array}$ \\
\hline $\begin{array}{l}2003 \\
13 \text { de febrero }\end{array}$ & $\begin{array}{l}\text { Las FARC secuestran a los estadounidenses Keith Stansell, Marc } \\
\text { Gonsalves y Thomas Howes tras la caída de la avioneta en la que } \\
\text { viajaban en las selvas del Caquetá. El } 2 \text { de julio de } 2003 \text {, el } \\
\text { Ejército Nacional rescata en las selvas de los departamentos de } \\
\text { Guaviare y Vaupés a los estadounidenses Stansell, Gonsalves y } \\
\text { Howes, así como a once policías y militares y a INGRID } \\
\text { BETANCUR. }\end{array}$ \\
\hline 5 de mayo & $\begin{array}{l}\text { El gobernador Gaviria, el ex ministro Echeverri y ocho militares } \\
\text { son asesinados por guerrilleros para impedir su rescate. }\end{array}$ \\
\hline 28 de junio & $\begin{array}{l}\text { Las FARC informan de que el } 18 \text { de junio, en un "fuego cruzado" } \\
\text { con "un grupo militar no identificado", murieron once de los doce } \\
\text { diputados del Valle del Cauca secuestrados en abril de } 2002 \text {. }\end{array}$ \\
\hline
\end{tabular}

Fuente: Elaboración propia, 2017 
Análisis Socio Jurídico del delito de secuestro en Colombia a partir de 1970

A través de medios de comunicación nos hemos enterado de secuestros que por el despliegue dado en la prensa y la naturaleza de la víctima han resultado ser mediáticos. Luego de su liberación, han ofrecido en diferentes entrevistas su versión sobre los vejámenes a que fueron sometidos durante su cautiverio.

\section{JORGE EDUARDO GECHEM TURBAY}

Fue secuestrado por las FARC el 20 de febrero de 2002 en la mañana, cuando secuestró el avión HK3951 de Aires que cubría la ruta Neiva-Bogotá con 30 pasajeros a bordo. En ese momento, los diálogos entre las Farc y el gobierno de Andrés Pastrana estaban en un momento tenso y se buscaba una tregua para salvar el proceso. Esa misma noche, en una locución presidencial, Andrés Pastrana Arango le puso final a los diálogos que se adelantaban en San Vicente del Caguán. En su intervención, el jefe de Estado le dio un plazo a las Farc para abandonar la zona de distención y a las Fuerzas Militares hacer nuevamente presencia en la región después de cuatro años de negociaciones. (El Espectador, 2014, párr., 4)

Gechem quien había sido senador de la república, duró seis años secuestrado y luego de su liberación manifestó a medios radiales que perdió 16 kilos de pesos, de pesar 96 kilos, paso a 80, además que el amor hacia su familia y el país fue el combustible de vida que le permitió soportar el secuestro y agradeció a su compañero de cautiverio Orlando Beltrán por el apoyo que le dio en los momentos más críticos. (Caracol Radio, 2008, párr., 1) 
Análisis Socio Jurídico del delito de secuestro en Colombia a partir de 1970

\section{INGRID BETANCUR}

En una entrevista concedida al diario El país de España, señalo:

Nosotros llevábamos el dolor del mundo a cuestas en todas sus expresiones. En la selva llevábamos una cruz completa. Conocimos el dolor en todas sus dimensiones. Primero, el dolor del alma por la pérdida de la libertad, que es como perder la dignidad. Lo que nos hace seres humanos es la posibilidad de tomar decisiones, todo el día estamos tomando decisiones, decisiones de a qué hora nos levantamos, qué comemos, adónde vamos, a quién vemos, qué palabras usamos, cómo nos vestimos, cómo priorizamos nuestras actividades del día. En un momento, el secuestrado pierde todo, no toma decisiones y se vuelve una cosa, un objeto al que llevan y traen y al que ninguna decisión le pertenece, ni la decisión de ir al baño, porque tienes que pedir permiso, ni la decisión de acostarte o levantarte, porque te la imponen, ni la de hablar con otro ser humano, porque también te lo condicionan, te lo prohíben o te lo permiten. Esa ausencia de uno mismo es el primer dolor que se lleva en el alma. A ése se le suman todos los demás dolores, los pequeños y los grandes. La selva es un lugar hostil. Todo duele en ella. La piel no es un espacio de protección, sino de dolor. En la selva, todo pica, todo rasca, todo incomoda. Tener un cuerpo en la selva es tener un peso adicional, porque el cuerpo es simplemente un espacio de dolor. Comer duele, ir al baño duele, bañarse duele, vivir duele, respirar duele, no ver el cielo duele, no ver a las personas que uno ama duele. (El País, 2008, párr., 20) 


\section{LUIS ELADIO PEREZ}

En entrevista rendida al portal de noticias francés RUE 89, el ex senador Nariñense que fuera secuestrado por la guerrilla de las FARC en 2001 y quien permaneció cautivo cerca de 7 años, manifestó:

Uno desarrolla estrategias de supervivencia. Para ejercitar los músculos del rostro durante los dos primeros años en los que permanecí callado, utilicé un espejito que me pasó una guerrillera. Para despertar la memoria, estando ya al lado de Ingrid, leímos innumerables veces el Quijote y la Biblia, que eran los únicos libros con los que contábamos. Para no dejar morir el intelecto, Ingrid nos daba clases de francés y los tres gringos, de inglés. Y para paliar la carencia de calcio, ella me dijo un día: Lucho, nos vamos a comer hasta las espinas de los pescados, que realmente era el alimento más rico que consumíamos porque, le digo una cosa, en esos siete años apenas me comí cinco frutas y seis porciones de carne. Entonces Ingrid me enseñó a tragar entero el esqueleto del pescado sin que uno se atore ni se haga daño en la garganta.

Uno prefiere estar muerto a vivir en esas circunstancias. Por eso decidimos fugarnos. La idea fue de Ingrid (Betancourt), ella consiguió todo, no sé cómo pero se las arreglaba para idearse las estrategias y conseguir las cosas más imposibles. Se inventó una especie de flotadores que camuflamos debajo de nuestras ropas y con seis galletas, media panela y tres anzuelos emprendimos la huida. Nadábamos en zig zag río abajo toda la noche y de día nos escondíamos de la guerrilla. Decían que había cerca de 900 hombres buscándonos. Nos alimentábamos de pescado crudo y así logramos sobrevivir cinco días hasta que se nos perdieron los anzuelos. Yo empecé a quebrarme 
a causa de mi diabetes. Y al sexto día no pudimos más (...) (Lors Rue 89, 2008, párr.,

\section{MARC GONSALVES}

Junto a Thomas Howes y Keith Stansell fueron secuestrados el 12 de febrero de 2003 luego de que la avioneta en el que viajaban fuera derribada por las FARC en la selva colombiana, en ese momento las FARC los acusaron de ser espías de la Agencia Central de Inteligencia (CIA). Los estadounidenses fueron liberados junto a otros secuestrados, incluyendo la ex candidata presidencial Ingrid Betancourt el 2 de julio de 2008 en la denominada operación jaque. En entrevista concedida al periódico nacional El tiempo, manifestó:

Eso obviamente no fue una experiencia agradable. Tengo un sueño recurrente de que soy recapturado por las Farc o que me toca combatir contra ellos. A veces veo una persona en la calle que se parece a un integrante de las Farc y eso me hace regresar a los años en la selva.

El otro día pasé cerca de un basurero y sentí un olor como a carne podrida. De inmediato volví a la selva porque a eso olía el campamento cuando se podría la comida. La primera noche que pase en libertad soñé que todo lo que había pasado, la operación Jaque, había sido un sueño. Fue horrible. Me pasa todavía, pero con los años cada vez menos. Ahora entiendo que la pesadilla acabó y que si pasa es solo en sueños pero cuando despierto sé que estoy en libertad. "Todavía sueño que soy secuestrado por las Farc”. (El Tiempo (2013, párr., 6) 


\section{GENERAL LUIS HERLINDO MENDIETA OVALLE.}

El General Mendieta quien en ese momento ostentaba el grado de Teniente Coronel de la Policía Nacional, fue secuestrado por las FARC, el 1 de noviembre de 1998 en la toma guerrillera que se realizara en la ciudad de Mitú departamento de Vaupés y fue rescatado por el Ejército Nacional de Colombia el 13 de junio de 2010.

En entrevista concedida al diario nacional El Tiempo en el año 2013, manifestó:

Realmente fue muy duro, no saber qué pasaba afuera, no escuchar una voz de aliento que venga desde el exterior de ese cautiverio es algo como para enloquecer, pero la esperanza es algo que como se dice, es lo último que se pierde, luchar por sobrevivir es más que innato es instinto y de todas formas la compañía de los demás cautivos ayuda, uno intenta sobrellevar la carga de ese mal momento tan largo y trata también de ver siempre el lado positivo, aprendí un poco de alemán al lado de Alan Jara que nos dio clases y también aprendí a bailar Joropo, es decir uno busca dispersar la mente y olvidar por un momento que está lejos ocupándose en otras cosas de alguna forma alegres. (Párr., 6)

El común denominador que se puede sacar de estos testimonios (como una pequeña muestra del sentimiento de la totalidad de las victimas del secuestro), es el dolor, la crueldad del secuestrador en este caso LAS FARC y la impotencia, la humillación pero ante todo la altivez y dignidad con que estas personas afrontaron el cautiverio, no obstante los que lograron salir de vida con él, tienen cicatrices físicas y psicológicas muy difíciles de borrar incluso con las muestras de perdón recibidas recientemente de miembros del secretariado de las FARC. En efecto, el pasado 11 de septiembre de 2016 el dirigente de las FARC Iván Márquez pidió en nombre de esta organización guerrillera, perdón por el daño causado por los secuestros que cometieron durante el 
Análisis Socio Jurídico del delito de secuestro en Colombia a partir de 1970

conflicto armado en Colombia, y reconocieron que esos actos provocaron un gran dolor y separaciones familiares.

Las FARC igualmente han manifestado públicamente que ha llegado la hora en que todos los involucrados en el conflicto reconozcamos responsabilidades y nos comprometamos resueltamente a garantizar el nunca más, pensando en el presente y en las generaciones futuras para que dentro de unos años vean en este acuerdo de paz el punto de partida de una nueva Colombia con felicidad y prosperidad, ratificando su compromiso "de no repetición”, y el deseo "de que dichas prácticas queden sepultadas para siempre con la guerra que culmina”. (Eju, 2016) 
Análisis Socio Jurídico del delito de secuestro en Colombia a partir de 1970

\section{Capítulo V. Legislación Expedida Sobre Secuestro en Colombia}

A lo largo de la historia de nuestro país, especialmente en los siglos XX y XXI el delito de secuestro se ha convertido en una verdadera amenaza para toda la ciudadanía, tanto de forma individual como colectiva, teniendo consecuencia en la estabilidad socioeconómica de nuestro país. Por tal situación, el Estado Colombiano con el propósito de prevenir el delito de secuestro ha venido implementado una serie de códigos penales y reformas a estos con el objetivo de combatir, prevenir y erradicar este fenómeno delictivo.

Por ello, se considera necesario hacer un recuento de las principales leyes y decretos que se han dictado en desarrollo de esta reacción estatal, seleccionadas dado el momento en que se expidieron y el anhelante designio que se procuraba, en la mayoría de los casos sin que se haya conseguido un efecto real empíricamente demostrable.

\subsection{Código Penal de 1936}

La ley 95 de 1936 dispuso en el TÍTULO XI denominado "Delitos contra la libertad individual y otras garantías", CAPITULO I "Del secuestro”, la creación de dos tipos penales, el de secuestro extorsivo (artículo 294) consistente en "secuestrar a una persona con el propósito de conseguir para sí o para otro un provecho o utilidad ilícitos” (Ministerio de Justicia, Ley 95 de 1936) y el de secuestro simple (artículo 295) en el cual incurría quien "injustamente privara a otro de su libertad" (Ministerio de Justicia, Ley 95 de 1936), fuera del caso previsto en el artículo anteriormente citado. 
Análisis Socio Jurídico del delito de secuestro en Colombia a partir de 1970

Estos artículos fueron modificados por el decreto número 1988 expedido el 9 de octubre de 1971, a través del cual se hace incremento de penas para el secuestro extorsivo "pasando el mínimo a imponer de uno a seis años de presidio y de seis meses a tres años en el evento se tratara del denominado secuestro simple" (Ministerio de Justicia, Decreto 1988 de 1971). Además a través de esta norma se adicionan causales de agravación de la pena cuando la víctima falleciere estando secuestrada, si el delito se comete en la persona de un inválido, de un menor de 16 años o mayor de 65, si se somete a la víctima a tortura física o moral, si el delito se cometía por dos o más personas, o por una sola disfrazada o que se finja agente de la autoridad, o con utilización de armas, y si se obtiene el provecho o utilidad ilícitos. (Ministerio de Justicia, Decreto 1988 de 1971).

\subsection{Código Penal De 1980}

El 23 de enero de 1980 se expide el decreto ley 100 , el cual conservó las mismas dos modalidades del Código de 1936 en el delito del secuestro, especificando mejor cada una de ellas y contempladas ahora en los artículos 268 (secuestro extorsivo y 269 (secuestro simple), manteniendo las penas mínimas consistentes en prisión de seis años en los casos en que se arrebate, sustraiga, retenga u oculte una persona con el propósito de exigir por su libertad un provecho o cualquier utilidad, o para que se haga u omita algo con fines publicitarios de carácter político (secuestro extorsivo) y prisión de seis meses cuando el secuestro haya sido con propósito distintos.

En el mismo sentido se enlistan como circunstancias de Agravación Punitiva cuando el delito se comete en persona de invalido, enfermo, menor de dieciséis años(16), mayor de sesenta (60) o en mujer embarazada, cuando se somete a la víctima a tortura física o moral durante el tiempo que permanezca secuestrada, cuando la privación de libertad del secuestrado se prolongare 
Análisis Socio Jurídico del delito de secuestro en Colombia a partir de 1970

por más de treinta días, si se comete en ascendiente, descendiente, adoptante o adoptivo, hermano o hermana, cónyuge o afín en línea directa en primer grado. Si se comete en personas que sea o hubiere sido empleado oficial y por razón de sus funciones ó cuando se presione la obtención de lo exigido con amenazas de muerte o lesión del secuestrado o con ejecutar acto que implique peligro común, grave perjuicio de la comunidad o la salud pública. (Redjurista, Decreto - Ley 100 de 1980)

Como un aspecto novedoso se establecen como circunstancias de Atenuación Punitiva, si dentro de los quince días siguientes al secuestro, se dejare voluntariamente en libertad a la víctima sin que se hubiere obtenido ninguno de los resultados previstos en el artículo 268 y en el caso del articulo 269 cuando dentro del mismo término la victima fuera dejado voluntariamente en libertad.

\subsection{Decreto 180 de 1988 ó Estatuto Antiterrorista}

Debemos comenzar recordando que para la época en diversos lugares del país venían operando reiteradamente grupos armados que en concepto del Estado Colombiano y el gobierno de la época, habían atentado contra el Régimen Constitucional, mediante lamentables hechos de perturbación del orden público y suscitando ostensible alarma en los habitantes. Por tal razón, para conjurar la grave situación especialmente en los departamentos de Caquetá, Huila, Meta y Cauca, el Gobierno declaró turbado el orden público y en estado de sitio el territorio de dichos departamentos por medio del Decreto 615 de 14 de marzo de 1984. No obstante persistieron los asaltos a poblaciones por obra de grupos armados, entre ellos los ocurridos sobre Acevedo en el departamento del Huila, Corinto en el departamento del Cauca, Sucre y Jordán Bajo en el 
Análisis Socio Jurídico del delito de secuestro en Colombia a partir de 1970

departamento de Santander, Giraldo en el departamento de Antioquia y Miraflores en la comisaria del Guaviare, con sus secuelas en la seguridad ciudadana, la tranquilidad y la salubridad públicas y en la economía nacional. (Ministerio de Justicia, Decreto 180 de 1988)

Para el mes de mayo de 1984, tuvieron ocurrencia actos terroristas en las ciudades de Medellín, Cali y Bogotá, causantes de la destrucción de numerosos vehículos de transporte colectivo y el 9 de mayo del mismo año fue asesinado el entonces Ministro de Justicia Rodrigo Lara Bonilla, grave situación que llevó al presidente Belisario Betancur Cuartas a adoptar las medidas de excepción contempladas en el artículo 121 de la Constitución Política, expidiendo el decreto 1038 de 10 de mayo de 1984 "a través del cual se declara turbado el orden público y en estado de sitio todo el territorio de la Republica” (Ministerio de Justicia, Decreto 180 de 1988)

El 27 de enero de 1988 se expide el Decreto 180 de 1988, Estatuto para la Defensa de la Democracia llamado también Estatuto Antiterrorista, "en el cual se complementaban algunas normas del Código Penal de 1980 y se dictaron otras disposiciones conducentes a los delitos que atentan contra la libertad individual y el patrimonio económico para el restablecimiento del orden público en el país" (Ministerio de Justicia, Decreto 180 de 1988). Este estatuto se estableció de manera transitoria debido al estado de sitio que como ya se dijo, aquejaba a Colombia desde 1984 con la muerte de Rodrigo Lara Bonilla Ministro de Justicia y de Guillermo Cano, Director del Diario El Espectador en 1987, hechos que desencadenaron el incremento del terrorismo, el narcotráfico y el secuestro con fines extorsivos. 
Análisis Socio Jurídico del delito de secuestro en Colombia a partir de 1970

Las penas sufrieron severas modificaciones, es así como en el capítulo segundo denominado "delitos que atentan contra la libertad individual y el patrimonio económico", en el artículo 22 se describe las acciones penada en el delito de secuestro, como las de arrebatar, sustraer, retener u ocultar a una persona, detallando una pena de prisión a imponer "entre quince y veinte años y multa de cien a doscientos salarios mínimos mensuales" (Ministerio de Justicia, Decreto 180 de 1988). Las circunstancias de agravación punitiva en este caso se dan cuando el delito se cometiere en persona de inválido, enfermo, menor de dieciséis años, mayor de sesenta años o mujer embarazada, si se somete a la víctima a tortura durante el tiempo que permanezca secuestrada, si la privación de libertad del secuestrado de prolongare por más de diez días, si se comete en ascendiente, descendiente, adoptante o adoptivo, hermano o hermana, cónyuge o afín en línea directa en primer grado, si se comete en persona que sea o hubiere sido empleado oficial y por razón de sus funciones, cuando se exija por la libertad del secuestrado un provecho o cualquier utilidad; cuando se presione la obtención de lo exigido con amenazas de muerte o lesión del secuestrado, o con ejecución de acto que implique peligro común, grave perjuicio de la comunidad o de la salud pública y cuando se cometa para hacer u omitir algo o con fines publicitarios de carácter político.

Mediante el decreto 1336 expedido el 23 de junio de 1990, "se toman medidas encaminadas al restablecimiento del orden público”, y se añade como causal de agravación:

Si el secuestro se comete en alguno de los funcionarios a que se refiere el artículo $1^{\circ}$ del Decreto 261 de 1988 o en la persona del cónyuge, ascendiente, descendiente, hermano, adoptante o adoptivo, o pariente hasta el primer grado de afinidad de cualquiera de ellos. (Ministerio de Justicia, Decreto 1336 de 1990). 
Análisis Socio Jurídico del delito de secuestro en Colombia a partir de 1970

Es de anotar que en el citado decreto 261 se hace alusión al homicidio con fines terroristas cuando las victimas resultaren ser:

Magistrado, Juez, Agente del Ministerio Público, Gobernador, Intendente, Comisario, Alcalde, posesionado o simplemente elegido, Personero o Tesorero Municipal, o miembro principal o suplente del Congreso de la República, de las Asambleas Departamentales, de los Consejos Intendenciales, de los Consejos Comisariales o de los Concejos Municipales o del Distrito Especial de Bogotá, Presidente de la República, Procurador General de la Nación, Contralor General de la República, Ministro del Despacho, Jefe de Departamento Administrativo, Candidato, Dirigente Político, Dirigente de Comité Cívico o Gremial, Periodista, Profesor Universitario, o Directivo de Organización Sindical, miembro de las Fuerzas Militares, Policía Nacional o de Organismo de Seguridad del Estado, Cardenal, Primado, Agente Diplomático o Consular, Arzobispo u Obispo. (Ministerio de Justicia, Decreto 261 de 1988)

\subsection{Decreto 2790 De 1990}

El 20 de noviembre de 1990 se expide el decreto 2790 "por el cual se dicta el Estatuto para la Defensa de la Justicia, integrando en una sola jurisdicción los Jueces de Orden Público y los Especializados, creando mecanismos jurídicos para su protección y la de los demás intervinientes en los procesos penales de su competencia, organizando la Subdirección Nacional y las Direcciones Seccionales de Orden Público para darles el apoyo operativo y necesario para el cumplimiento de sus funciones y robusteciendo los organismos auxiliares". 
Análisis Socio Jurídico del delito de secuestro en Colombia a partir de 1970

En efecto la motivación para la expedición de esta norma fue la expedición del decreto 1038 de 1984 a través del cual se había declarado turbado el orden público y en estado de sitio todo el territorio nacional, para combatir las perturbaciones producidas por bandas de terroristas y de narcotraficantes, que las acciones de estos grupos persistían, causando no sólo muchas pérdidas de vidas en los miembros de la comunidad, sino también entre los jueces y demás personas que por razón de sus funciones deben participar en los procesos que se adelantan contra ellos, además que era necesario buscar mecanismos jurídicos que permitan dar seguridad a los jueces de la República y a las demás personas que vienen siendo objeto de atentados por razón de su participación en las investigaciones adelantadas contra sus integrantes y por ende había que dotar a la jurisdicción de orden público de un soporte administrativo eficiente que permita a sus integrantes cumplir su función en forma adecuada, así como robustecer la capacidad operativa de los cuerpos auxiliares de la justicia para que puedan luchar eficazmente contra las organizaciones delictivas que perturban la tranquilidad del país. (Ministerio de Justicia, Decreto 2790 de 1990)

En el artículo 6 del decreto en cita se consagra como tipo penal autónomo el secuestro dirigido contra persona que ocupe alguno de los cargos mencionados en el numeral $1^{\circ}$ del artículo $2^{\circ}$ del Decreto 474 de 1988 o en funcionario de la Rama Jurisdiccional, Registrador Nacional del Estado Civil, Miembro del Consejo Electoral, Delegado del Consejo Nacional Electoral o el Registrador, Registrador Departamental, o Municipal del Estado Civil, Agente del Ministerio Público, Agente Diplomático o Consultar al servicio de la Nación o acreditado ante ella, Comandante General o miembro de las Fuerzas Armadas, de la Policía Nacional o de los Cuerpos de Seguridad, Subdirector 
Análisis Socio Jurídico del delito de secuestro en Colombia a partir de 1970

Nacional de Orden Público, Director Seccional de Orden Público, Miembro de la Asamblea Nacional Constitucional, Miembro principal o suplente de las Asambleas Departamentales, funcionario elegido por Corporación de elección popular, Cardenal, Primado, Arzobispo, Nuncio y Obispo; o se ejecute con fines terroristas; u obedezca a los propósitos descritos en el artículo $1^{\circ}$ del Decreto 1631 de 1987 o persiga los objetivos enunciados en el artículo 268 del Código Penal, sancionando estas conductas con prisión de veinte a veinticinco años y multa de un mil a dos mil salarios mínimos legales mensuales. (Corte Constitucional, Sentencia No. C-127/93)

Se debe destacar que a través de este decreto 2790 de 1990 ó Estatuto para la defensa de la justicia, se dio origen a la Justicia Regional, también llamada Justicia sin rostro la cual debió concluir el 30 de junio porque así lo consagró la Ley Estatutaria de la Administración de Justicia en 1996 y es a través de la ley 504 de 1999 que se hace la transición de la justicia regional a la justicia especializada. Se debe recordar que no obstante las discusiones que generó la implementación de la justicia regional dada la evidente restricción de garantías procesales, está siempre estuvo avalada por la Corte Constitucional que a manera de ejemplo mediante la Sentencia de Constitucionalidad 272 del 28 de Abril de 1999 señaló que:

Tales restricciones son aceptables a la luz de la normatividad constitucional siempre y cuando quede a salvo el núcleo esencial del derecho fundamental al debido proceso, siendo necesario que se asegure el derecho constitucional fundamental a la defensa y a la contradicción, advirtiendo que se trata de formas especiales de administración de justicia en las cuales las garantías del debido proceso operan con ciertas restricciones dada la complejidad de los delitos que se investigan. 


\subsection{Decreto 2266 de 1991}

Como se ha venido resaltando, para finales de los años 80 e inicios de la década de los 90, se presenta un duro enfrentamiento contra el narcotráfico por parte de las fuerzas legalmente constituidas lideradas por el gobierno Nacional, es así como el asesinato del entonces candidato presidencial Luis Carlos Galán, permite lanzar una propuesta de reforma estructural en el año de 1988 proponiendo un plebiscito para modificar la constitución, proposición que no logró consenso y por ende fracasó. En efecto en el mes de diciembre de 1989, el gobierno del presidente BARCO propuso convocar a un "Referendo extraordinario por la paz y la democracia", para consolidar los acuerdos de paz con la guerrilla del M-19. Debido a la presión violenta del narcotráfico, especialmente por el autodenominado grupo de "los extraditables" se quiso aprovechar la consulta con el pueblo para que se pronunciara también sobre la extradición, lo que causó que el gobierno desistiera de la totalidad del proyecto. (Hernández, 2003)

Posteriormente surge movimiento estudiantil denominado "la séptima papeleta" el cual tuvo su origen tras la opresión, la violencia y la inconformidad que atravesaba Colombia que fue detonada con la muerte del líder liberal, cuyo objetivo no fue otro que fortalecer la democracia participativa y recuperar su espacio que venía siendo usufructuado por los violentos y opresores. Es así como en agosto de 1989 se realiza la Marcha del Silencio, en repudio por el asesinato de Luis Carlos Galán, manifestando los universitarios su inconformidad que daría inicio a la revolución estudiantil de la llamada séptima papeleta, que abrió el camino para la convocatoria de la Asamblea Nacional Constituyente y es por tanto el origen de la Constitución de 1991. (El Pais.com, 2011)

En dichas elecciones se registró más de 2 millones de papeletas a favor -de 7.6 millones de votantes que acudieron a las urnas y de 13 millones de votantes habilitados-. Ante 
Análisis Socio Jurídico del delito de secuestro en Colombia a partir de 1970

la importancia de los resultados, la Corte Suprema avaló una consulta formal en las siguientes elecciones presidenciales del 27 de mayo de 1990. En esa consulta el 86\% de los votantes se pronunció a favor. El 9 de diciembre de 1990, mediante unas elecciones convocadas por el recién posesionado presidente César Gaviria, fueron elegidos los 70 miembros de la asamblea constituyente. Adicionalmente, para darle impulso a las negociaciones de paz con otros grupos guerrilleros, se dio la posibilidad de participación con voz pero sin voto a 4 representantes de estos grupos: 2 del ejército popular de liberación (EPL), uno del Partido Revolucionario de los Trabajadores (PRT) y otro del movimiento armado Quintín Lame. El proceso de discusiones duró hasta el 4 de Julio de 1991, cuando todos los Delegatarios Constituyentes firmaron la redacción final de la constitución en una ceremonia llevada a cabo en el salón elíptico del capitolio nacional. (Historia Constitución política de Colombia, 2011)

Eliminado el estado de sitio por la constitución de 1991 en un artículo transitorio de esta norma se creó la llamada Comisión Especial Legislativa (Conocido popularmente como Congresito), que fue el organismo encargado de estudiar cuáles disposiciones del estado de sitio eliminado por la constitución del 91, podían convertirse en legislación permanente. Esa comisión consideró que el Estatuto Antiterrorista y sus normas complementarias debían quedar como normas permanentes para evitar que por el principio de favorabilidad los condenados por los llamados delitos atroces pudieran lograr la excarcelación éste decreto el 2266 de 1991 por el cual se adopta unas normas por legislación permanente. 
Análisis Socio Jurídico del delito de secuestro en Colombia a partir de 1970

\subsection{Ley 40 de 1993 ó Estatuto Antisecuestro}

A consecuencia del preocupante incremento del secuestro de personas indefensas, el Congreso de la República, por iniciativa popular, expidió la ley 40 de 1993, comúnmente conocida como "Estatuto Antisecuestro":

Cuyo norte esencial fue el de neutralizar, debilitar y malograr la estructura logística y la capacidad operativa de la delincuencia organizada que ha hecho del secuestro una macabra industria ilícita, así como fortalecer los sistemas de protección y de garantía a los valores, principios fundacionales y derechos más caros al Estado social de derecho, en que por decisión del Constituyente se erige Colombia, como son los invaluables e inviolables dones de la vida y la libertad, tan seriamente amenazados por esta monstruosa modalidad criminal. (Corte Constitucional, Sentencia No. C-565/93)

La Corte Constitucional en uno de los exámenes de exequibilidad realizados a esta ley, recordó que la iniciativa popular que dio lugar a la expedición de la ley en referencia, refirió estadísticas que mostraban que en el período comprendido entre 1964 y 1991 se cometieron en el país 7.453 secuestros, y solamente en el año 1991 se cometieron 1408. Resalta que en promedio sólo el 12\% de los casos culminan en el rescate de la víctima, el $10 \%$ de los secuestrados son asesinados y el $45 \%$ liberados tras el pago de una suma millonaria, que el pago promedio por secuestro es de 50 millones de pesos. Destaca que entre 1987 y 1991 se pagaron 175.000 millones de pesos en rescates a los secuestradores y que apenas el $20 \%$ de los casos de secuestro son denunciados a las autoridades lo cual suponía que todas estas estadísticas subestiman la magnitud verdadera del fenómeno. (Corte Constitucional, Sentencia No. C-565/93) 
Análisis Socio Jurídico del delito de secuestro en Colombia a partir de 1970

En el mismo sentido, en la exposición de motivos de la ley 40 de 1993 se subraya que el secuestro en Colombia para la época afectaba a todas las clases sociales, en consecuencia, así como existían secuestros en los cuales se involucraban sumas millonarias, en igual sentido se presentaron casos de secuestro entre las familias de clase media y aún de extracción social baja en los cuales los rescates llegan hasta unos pocos miles de pesos. Ello por cuanto a partir de la amnistía de los grupos guerrilleros y las acciones contra el narcotráfico se produjo un fenómeno de desempleo para quienes se dedicaban a este tipo de acciones, lo que trajo como consecuencia la formación de bandas de delincuentes que se dedican a secuestrar, pero no a personas de grandes recursos económicos, que tienen el apoyo de las autoridades e influencias políticas, sino a personas de medianos recursos, que por no contar con estos apoyos, deben necesariamente cancelar las sumas que se les piden y que normalmente no sobrepasan el millón de pesos.

Por esta situación que vivía nuestro país para la época, se hizo necesaria una profunda modificación a la legislación que regulaba el delito del secuestro, por cuanto las disposiciones vigentes se consideraron insuficientes tanto por su contenido como por sus alcances para erradicar en forma definitiva uno de los crímenes más abominables de la humanidad, a saber, el secuestro que venía afectando en forma directa a miles de familias colombianas. (Corte Constitucional, Sentencia c 542 de 1993)

Sobre el incremento de penas para el delito de secuestro que se efectuó en la ley 40 de 1993 la corte constitucional aseveró que se hace necesaria si tiene en cuenta el fenómeno creciente de la criminalidad y delincuencia en nuestro país en los últimos años, ante lo cual se torna imperioso evaluar las posibilidades y la verdadera eficacia de la justicia penal y de las sanciones por ella previstas, para efectos de garantizar la protección de los bienes jurídicos más fundamentales para el ser humano. 
Análisis Socio Jurídico del delito de secuestro en Colombia a partir de 1970

Y más adelante la Corte agrega que:

De ahí que, en particular, tratándose de esta modalidad delictiva, la pena cumpla un importante y significativo efecto sicológico, con la representación que en su quantum se hace de la gravedad misma del delito de secuestro, el cual amerita la imposición de sanciones verdaderamente severas, que den cuenta del profundo repudio que causa a la sociedad este tipo de delitos que se insiste, es uno de los más abominables y detestables. (Corte Constitucional, Sentencia No. C-565/93)

Una ley que endurezca la actitud contra el secuestro, es efectivamente una ley que está llamada a producir importantes efectos disuasivos. (...) Por todo ello, no estima la Corte que la imposición de sanciones elevadas (en cuanto al número de años de prisión) para delitos de semejante gravedad y atrocidad, como el secuestro y el homicidio, cometidos contra los derechos esenciales del ser humano -la vida, la libertad, la dignidad, la convivencia pacífica, la familia, la intimidad, entre otrosconstituya, como lo pretende la censura, agravio alguno a las disposiciones constitucionales invocadas en la demanda. Por el contrario, una de las formas, quizá la más idónea para asegurar los fines del Estado, sea la de garantizar la convivencia pacífica, la cual se logra a través de la prevención y represión de las conductas delictivas mediante la imposición de penas y sanciones que sean verdaderamente proporcionales a la gravedad del hecho punible y a la mayor o menor afectación de los derechos fundamentales de las personas. (Corte Constitucional, Sentencia No. C565/93).

Añadiendo que: 
Análisis Socio Jurídico del delito de secuestro en Colombia a partir de 1970

Sanciones como las previstas en las normas acusadas atienden los fines de retribución, ya que su quantum responde a la necesidad de represión de conductas punibles; además, satisfacen los objetivos de la función preventiva como quiera que su rigor se endereza a evitar la consumación de nuevos hechos delictivos, castigando en forma ejemplarizante a todos aquellos que pretendan incurrir en esa modalidad punible. (Corte Constitucional, Sentencia No. C-565/93)

Es de la esencia del examen de exequibilidad de estas normas, la consideración que hace la Corte Constitucional ubicando como la verdadera columna del Estatuto Antisecuestro, la persecución de los delitos atroces con los medios legales correspondientes ajustados a la Constitución, uno de los cuales es el castigo ejemplar de quienes incurran en los delitos atroces para que, con la observancia de los procedimientos legales que informan el debido proceso, se les impongan penas como las consignadas en la ley 40 de 1993 en defensa de los derechos fundamentales a la vida, la dignidad y la libertad, entre otros.

En esta ley se tipifican las diferentes conductas criminales y se agravan las penas contra estos delitos. El secuestro simple, queda con una pena de seis a veinticinco años, incluida además con una multa de cien a doscientos salarios mínimos legales mensuales vigentes. Y el secuestro extorsivo queda con una pena de veinticinco a cuarenta años de prisión y con una multa de cien a quinientos salarios mínimos.

Las circunstancias de agravación punitiva de las penas respecto al secuestro extorsivo, se enlistan en el art. 3, Cap. 1 de la LEY ANTISECUESTRO y se dan cuando el delito se comete en persona invalida o enferma, o de menos de dieciocho (18) años, o que no tenga la plena capacidad de autodeterminación o que sea mujer embarazada, cuando se somete a la víctima a tortura física 
Análisis Socio Jurídico del delito de secuestro en Colombia a partir de 1970

o moral o a violación sexual durante el tiempo que permanezca secuestrada, cuando la privación de la libertad del secuestrado se prolonga por más de quince (15) días, cuando se ejecuta la conducta respecto de pariente hasta el cuarto grado de consanguinidad, cuarto de afinidad o primero civil, sobre cónyuge o compañera o compañero permanente, o aprovechando la confianza depositada por la víctima en el autor o en alguno o algunos de los copartícipes, cuando el delito se comete por persona que sea empleado oficial o que sea o haya sido miembro de las fuerzas de seguridad del Estado, cuando se comete en persona que sea o hubiere sido empleado oficial, periodista o candidato a cargo de elección popular y por razón de sus funciones, cuando se presione la entrega o verificación de lo exigido, con amenaza de muerte o lesión o con ejecutar acto que implique grave peligro común o grave perjuicio a la comunidad o a la salud pública, cuando se cometa con fines terroristas, cuando se obtenga la utilidad, provecho o finalidad perseguidos por los autores o copartícipes, cuando se afecten gravemente los bienes o la actividad profesional o económica de la víctima, cuando por causa o con ocasión del secuestro le sobrevengan a la víctima la muerte o lesiones personales, cuando se comete en persona que sea o haya sido dirigente comunitario, sindical, político o religioso y cuando el hecho se comete utilizando orden de captura o detención falsificada o simulando tenerla. (Corte Constitucional, Sentencia No. C-213/94)

Además se establecen como Circunstancias de atenuación punitiva para este delito Si dentro de los quince días siguientes al secuestro, se dejare voluntariamente en libertad a la víctima, sin que se hubiere obtenido alguno de los fines previstos en el tipo penal de secuestro extorsivo y en los eventos del Secuestro Simple si el secuestrado, dentro del mismo término fuere dejado voluntariamente en libertad. (Corte Constitucional, Sentencia No. C-213/94)

En esta ley 40 de 1993, aparecen nuevas figuras contra el delito, tales como el concierto para secuestrar (art 5), enriquecimiento ilícito derivado del secuestro (art 6), favorecimiento (art 
Análisis Socio Jurídico del delito de secuestro en Colombia a partir de 1970

7), receptación (art 8), omisión de informes (art 9), omisión de aviso (art 10), la obligación especial de investigación (art 11) y la celebración indebida de contratos de seguro (art 12)

\subsection{Ley 282 de Junio de 1996}

A través de esta norma se conforman los grupos especiales para actuar contra los autores y partícipes en los delitos de secuestro y extorsión conocidos como GAULA, y se atribuye facultades especiales a los fiscales delegados, ante cada unidad operativa, y regula otros aspectos relacionados con las actividades específicas que estos deben cumplir.

Por otra parte en el artículo 11 se crea un nuevo agravante para el delito de secuestro, que se da cuando se trafique con la persona secuestrada durante el tiempo de privación de la libertad, así mismo se crea como tipo penal autónomo en el Artículo 12 el delito de Provecho ilícito por error ajeno proveniente de secuestro o extorsión y en el artículo 14 se crea un Procedimiento abreviado. En los casos de flagrancia, dentro del cual en las investigaciones por delitos de secuestro, extorsión y conexos, de competencia de los jueces regionales, se debería disponer el cierre de la investigación, a más tardar, pasados cinco días de ejecutoriada la providencia en la que se resuelva la situación jurídica que imponga medida de aseguramiento al sindicado. (Sentencia de Constitucionalidad $N^{\circ} 272 / 99$ de Corte Constitucional)

Dicho artículo 14 fue declarado inexequible por la honorable Corte Constitucional, la cual consideró que en el corto plazo de cinco días mal podrá desarrollarse una exhaustiva y completa tarea probatoria, lo cual no sólo es violatorio del derecho fundamental al debido proceso del procesado sino que además contraviene la autonomía e independencia de la administración de justicia y la obligación que la Carta Política impone a la Fiscalía General de la Nación de investigar 
tanto lo favorable como lo desfavorable al imputado (C.P., artículo 250). (Sentencia de Constitucionalidad $\mathrm{N}^{\circ} 272 / 99$ de Corte Constitucional)

\subsection{Ley 599 de 2000}

La Ley 599 expedida en julio 24 de 2000 código penal que nos rige actualmente, disminuye las penas en el delito del secuestro, describiendo en el artículo 168 el secuestro simple cuando una persona indeterminada con propósitos distintos al extorsivo, arrebate, sustraiga, retenga u oculte a una persona y en el artículo 169 el secuestro extorsivo cuando una persona indeterminada arrebate, sustraiga, retenga u oculte a una persona con el propósito de exigir por su libertad un provecho o cualquier utilidad, o para que se haga u omita algo, o con fines publicitarios o de carácter político. Las penas señaladas para el secuestro simple son de prisión de diez a veinte años y multa de seiscientos a mil salarios mínimos legales mensuales vigentes y para el extorsivo de prisión de dieciocho a veintiocho años y multa de dos mil a cuatro mil salarios mínimos legales mensuales vigentes. (Congreso de Colombia, Ley 599 de 2000)

Respecto de las causales de agravación para el secuestro extorsivo que trata el artículo 170 de la ley 599 de 2000, se tiene que varía la pena establecida en la ley 40 de 1993 ya que las aumenta en una tercera parte y admite como circunstancias agravantes cuando la conducta se cometa en persona discapacitada que no pueda valerse por sí misma o que padezca enfermedad grave, o menor de dieciocho (18) años, o que no tenga la plena capacidad de autodeterminación, o que sea mujer embarazada, cuando la privación de la libertad del secuestrado se prolonga por más de quince días, cuando se ejecuta la conducta respecto de pariente hasta el cuarto grado de consanguinidad, cuarto de afinidad o primero civil, sobre cónyuge o compañera o compañero 
Análisis Socio Jurídico del delito de secuestro en Colombia a partir de 1970

permanente, o aprovechando la confianza depositada por la víctima en el autor o en alguno o algunos de los partícipes, cuando la conducta se realice por persona que sea servidor público o que sea o haya sido miembro de las fuerzas de seguridad del Estado, cuando se presione la entrega o verificación de lo exigido con amenaza de muerte o lesión, o con ejecutar acto que implique grave peligro común o grave perjuicio a la comunidad o a la salud pública, cuando se cometa con fines terroristas, cuando se obtenga la utilidad, provecho o la finalidad perseguidos por los autores o partícipes, cuando se afecten gravemente los bienes o la actividad profesional o económica de la víctima, cuando se comete en persona que sea o haya sido periodista, dirigente comunitario, sindical, político, étnico o religioso en razón de ello, cuando se trafique con la persona secuestrada durante el tiempo de privación de la libertad, y cuando se cometa en persona internacionalmente protegida diferente a las señaladas en el título II de éste Libro y agentes diplomáticos, de conformidad con los Tratados y Convenios Internacionales ratificados por Colombia. (Congreso de Colombia, Ley 599 de 2000)

Como circunstancias de atenuación punitiva el artículo $171 \mathrm{del} \mathrm{cp}$, se dan cuando dentro de los quince días siguientes al secuestro se dejare voluntariamente en libertad a la víctima, sin que se hubiere obtenido alguno de los fines previstos para el secuestro extorsivo y en los eventos del secuestro simple si el secuestrado, dentro del mismo término, fuere dejado voluntariamente en libertad. (Congreso de Colombia, Ley 599 de 2000) 


\subsection{Ley 733 de 2002}

Los motivos que dieron lugar a la expedición de esta norma en el mes de enero del año 2002, por la cual se dictaron medidas tendientes a erradicar los delitos de secuestro, terrorismo y extorsión, y se adoptaron otras disposiciones,

Obedecen a que para la época, el secuestro al igual que el terrorismo y la extorsión, eran considerados como delitos atroces y abominables causantes de una gran alarma social y quebrantan o afectan, en forma grave y ostensible, valores y derechos inalienables del ser humano como la vida, la dignidad, la libertad personal, la intimidad, el libre desarrollo de la personalidad, la libre circulación, el trabajo, la familia, la libre participación ciudadana y la paz, todos amparados por la Constitución Política y las leyes. (Gacetas del Congreso, 380 septiembre de 2000)

Por tal razón resultaba imperioso que en procura de golpear y destruir la estructura delictiva de las organizaciones criminales, y de entregarle herramientas al Estado para combatir tales delitos ante su auge durante las últimas dos décadas, ya que con la expedición de las leyes 599 y 600 de 2000, en criterio del legislador las medidas especiales adoptadas en las leyes 40 de 1993 y 282 de 1996 se vieron en cierta medida afectadas y disminuidas, no obstante que el secuestro, el terrorismo y la extorsión continuaban consolidándose como una verdadera industria y un negocio de gran rentabilidad a cargo de los grupos subversivos, narcotraficantes, de la delincuencia común y últimamente también de los paramilitares. (Corte Constitucional, Sentencia C-762/02)

Precisamente otro motivo determinante que tuvo en cuenta el legislador, reside en que los actores armados del conflicto en Colombia, especialmente los grupos guerrilleros y paramilitares se dedicaron a perpetrar secuestros masivos e indiscriminados contra los civiles que se 
Análisis Socio Jurídico del delito de secuestro en Colombia a partir de 1970

transportaban por vía terrestre, aérea y marítima pertenecientes a todos los estamentos sociales, utilizándolos como escudos humanos para dificultar la reacción de las autoridades legítimamente constituidas, y luego, exigiendo el pago de rescates o la entrega de bienes por la libertad de los secuestrados, y ante esta arremetida la población convivía con el temor permanente de ser víctimas del flagelo de la extorsión y el secuestro, afectándose y poniéndose en peligro con tan dolorosas y repudiables conductas la existencia y la convivencia nacional.

Es por esta grave situación de riesgo e inseguridad, donde se ven comprometidos los derechos más íntimos y valiosos de todos y cada uno de los integrantes de la sociedad, que se hizo necesario reconsiderar algunas de las medidas que en relación con tales delitos fueron prohijadas en el código penal, debiéndose mejorar las hasta ahora existentes y adoptar unas nuevas, con el ánimo de combatir con mayor severidad el terrorismo, el secuestro, la extorsión y los delitos conexos. Sobre esta base en la citada Ley 733 de 2002 se dispuso elevar las penas para punibles entre otros el de secuestro, aumentar las circunstancias de agravación punitiva para el secuestro y la extorsión, mantener como circunstancia de atenuación punitiva para los delitos de secuestro simple y extorsivo, el que se haya puesto en libertad a la víctima en forma voluntaria y sin haber obtenido el provecho ilícito, excluir para el terrorismo, el secuestro y la extorsión los subrogados y beneficios penales, prohibir el otorgamiento de amnistías e indultos y eliminar la posible consideración de ser tratados como delitos políticos y en relación con los delitos contenidos en dicha ley reducir los términos de instrucción y juzgamiento a la mitad para los casos de flagrancia, y otorgarle a los jueces penales del circuito especializados la competencia para conocer de los mismos. (Corte Constitucional, Sentencia C-762/02)

Sobre la exclusión de beneficios y subrogados que trata el artículo 11 de la ley 733 de 2002, la Corte Constitucional, sostuvo: 
Análisis Socio Jurídico del delito de secuestro en Colombia a partir de 1970

Que tales medidas, al igual que ocurre con el señalamiento de los comportamientos delictivos y la fijación de las penas, responden a un asunto de política criminal que compete planear y desarrollar al Congreso de la República, de acuerdo a una previa valoración de conveniencia política y, en especial, teniendo en cuenta la gravedad de las conductas delictivas y el daño que éstas puedan causar a la sociedad. Así las cosas preciso la Corte que la inclusión o exclusión de beneficios y subrogados penales guarda estrecha relación con la duración de la pena privativa de la libertad y, de ningún modo, con las garantías procesales que le permiten al sindicado intervenir en la actuación judicial y ejercer plenamente su derecho a la defensa. (Corte Constitucional, Sentencia C-762/02)

Por ello, para la Corte Constitucional, sin tener por qué afectar, comprometer o desconocer los presupuestos sustanciales y adjetivos concebidos a favor de todos los imputados, con la exclusión de los beneficios y subrogados penales lo que se busca es evitar que resulte nugatorio, desproporcionado o irrisorio, el reproche social impuesto para los delitos más graves y de mayor impacto social como el terrorismo, el secuestro, la extorsión y sus conexos; que, como se dijo, quebrantan en forma significativa los valores de gran relevancia individual y colectiva, desestabilizando incluso el propio orden institucional. (Corte Constitucional, Sentencia C-073/10)

Además de la exclusión de subrogados y beneficios la ley 733 de 2002, en su artículo 3 se crean otras circunstancias de agravación para el secuestro extorsivo como lo son, cuando la conducta se comete total o parcialmente desde un lugar de privación de la libertad, cuando la conducta se comete parcialmente en el extranjero, cuando se trafique con la persona secuestrada durante el tiempo de privación de la libertad y cuando se cometa en persona internacionalmente protegida diferente o no en el 
Derecho Internacional Humanitario y agentes diplomáticos, de las señaladas en los

Tratados y Convenios Internacionales ratificados por Colombia. (Congreso de Colombia, Ley 733 de 2002)

Los artículos 168 y 169 de la ley 599 de 2000 fueron modificados por el artículo 14 de la Ley 890 de 2004, a través de la cual las penas consagradas para los tipos penales contenidos en la Parte Especial del Código Penal se aumentaron en la tercera parte en el mínimo y en la mitad en el máximo, ley que empieza a regir a partir del 1o. de enero de 2005. A manera de ejemplo, con el incremento que hace esta ley la pena mínima para el secuestro extorsivo que trae el artículo 169 de 20 años (240 meses) debe ser aumentada en 80 meses, quedando una pena mínima a imponer de 320 meses. (Congreso de Colombia, Ley 599 de 2000)

\subsection{Ley 1121 de 2006}

En agosto de 2002 el presidente Álvaro Uribe Vélez inicia su mandato con la intención de recuperar las zonas bajo dominio de las guerrillas colombianas en el contexto de ruptura de los “diálogos de paz" instaurados durante el gobierno del presidente Andrés Pastrana Arango y el escenario internacional de "lucha contra el terrorismo". E1 contexto en el que se inscribe el gobierno del presidente Uribe da cuenta de una enorme incapacidad estatal para asegurar el control de ciertas zonas centrales y periféricas de domino paramilitar, de las guerrillas FARC o ELN. Ello en razón de la expansión de estos grupos al margen de la ley durante el proceso de paz del gobierno del presidente Andrés Pastrana. (Parra, 2013, p.26) 
Análisis Socio Jurídico del delito de secuestro en Colombia a partir de 1970

Así las cosas, el gobierno de Álvaro Uribe Vélez inicia con la declaración de estado de conmoción interior. De acuerdo al decreto 1837 de 2002 los motivos que invoca el gobierno para declarar el estado de excepción son principalmente los siguientes: la situación de inseguridad cuya causa principal son "bandas armadas, organizadas [...]", la amenaza a mandatarios locales, regionales y nacionales y por lo tanto al funcionamiento de las instituciones democráticas, la insuficiencia de los recursos económicos y militares a disposición del Estado para contrarrestar la violencia, entre otros. Atendiendo a los motivos, el gobierno considera "necesario aumentar y mejorar la capacidad técnica y el equipamiento que requieren las Fuerzas Armadas y de Policía para desarrollar los operativos necesarios que permitan enfrentar los ataques a poblaciones y ciudadanos”. (Alcaldía Mayor de Bogotá, Decreto 1837 de 2002)

En ese contexto, el 29 de diciembre de 2006 el congreso de la república expide la ley 1121 por la cual se dictan normas para la prevención, detección, investigación y sanción de la financiación del terrorismo y otras disposiciones, disponiendo específicamente en su artículo 26 que cuando se trate de delitos de terrorismo, financiación de terrorismo, secuestro extorsivo, extorsión y conexos, no procederán las rebajas de pena por sentencia anticipada y confesión, ni se concederán subrogados penales o mecanismos sustitutivos de la pena privativa de la libertad de condena de ejecución condicional o suspensión condicional de ejecución de la pena, o libertad condicional. Tampoco a la prisión domiciliaria como sustitutiva de la prisión, ni habrá lugar ningún otro beneficio o subrogado legal, judicial o administrativo, salvo los beneficios por colaboración consagrados en el Código de Procedimiento Penal, siempre que esta sea eficaz. (Corte Constitucional, Sentencia C-073/10) 
Análisis Socio Jurídico del delito de secuestro en Colombia a partir de 1970

En el análisis de exequibilidad del artículo en cita la Corte Constitucional Sentencia C073/10, destaca que el legislador puede establecer, merced a un amplio margen de configuración, sobre cuáles delitos permite qué tipo de beneficios penales y sobre cuáles no. Dentro de esos criterios, los más importantes son: “el análisis de la gravedad del delito y la naturaleza propia del diseño de las políticas criminales, cuyo sentido incluye razones políticas de las cuales no puede apropiarse el juez constitucional" (Corte Constitucional, Sentencia C-073/10).

\subsection{Ley 1200 de 2008}

Para el año 2006 la Fundación País Libre observaba con preocupación la metamorfosis del delito; de un lado, el secuestro "urbano", ligado al nuevo modus operandi de los secuestradores y, por otro, su escasa denuncia. Se trataba de la modalidad de secuestro "paseo millonario" o "secuestro exprés", que consiste en la retención de personas que hacen uso del transporte público, taxis, principalmente en las horas de la noche. Personas que aparte de ser plagiadas, son vejadas en la mayoría de los casos, amenazadas y obligadas a desocupar sus cuentas bancarias a cambio de su libertad. (Silva, 2007, p.372)

A través de la Ley 1200 expedida el 23 de junio de 2008 se adicionó el artículo 169 del Código Penal, anteriormente modificado por los artículos $2^{\circ}$ de la Ley 733 de 2002 y 14 de la Ley 890 de 2004, agregando el siguiente inciso: "igual pena se aplicará cuando la conducta se realice

temporalmente en medio de transporte con el propósito de obtener provecho económico bajo amenaza”. (Congreso de Colombia, Ley 1200 de 2008). 
Análisis Socio Jurídico del delito de secuestro en Colombia a partir de 1970

Los motivos que llevaron al legislador a expedir esta norma, están relacionados con la necesidad que se tenía de remediar definitivamente la inseguridad jurídica y la desigualdad en el tratamiento de litigios de similar naturaleza surgida por causa del vacío legal en relación con la conducta llamada popularmente como paseo millonario, siendo imperativo tipificarla en consonancia con la interpretación realizada por la sala penal de la Corte Suprema de Justicia Sala de Casación Penal de la Corte Suprema de Justicia contenida en la sentencia de 25 de mayo de 2006 (Rad. 20.326), con ponencia del doctor Edgar Lombana Trujillo, adecuándola no como un simple hurto calificado y agravado, sino como una modalidad de Secuestro extorsivo.

\subsection{Medidas de protección a víctimas de secuestro y sus familias}

\subsubsection{Ley 986 de 2005.}

El secuestro se puede considerar como uno de los delitos que acarrea graves y duraderos perjuicios psicológicos y económicos a sus víctimas y a sus familiares, daños que se hacen aún más notorios en nuestro país, que detenta el triste récord de haber sido el líder mundial en secuestros durante muchos años. Desde el terreno legal, los esfuerzos para combatir esta práctica, desde la expedición del Estatuto Nacional contra el Secuestro (L. 40/93) se concentraron en el aspecto represivo y se dejó de lado una necesaria política integral de atención y asistencia a sus familiares, ante esta omisión del Legislativo, fue la Corte Constitucional la encargada de delimitar inicialmente los derechos y deberes del Estado y de los empresarios ante una situación de secuestro. Esa protección se tradujo, mediante la acción de tutela, en el pago por parte de empleadores de salarios y prestaciones sociales a esposas y familiares de trabajadores secuestrados, ordenadas por sentencias como la T-15 de 1995, la T-637 de 1999 y la T-1634 del 2000. En el mismo sentido el Gobierno Nacional realizó esfuerzos por consagrar legalmente esa 
Análisis Socio Jurídico del delito de secuestro en Colombia a partir de 1970

obligación de los empleadores —al menos en el caso de empleadores que contrataran a más de 50 trabajadores - en los decretos legislativos 1723 de 1995 y 2238 de 1996, que fueron declarados inexequibles por la misma Corte Constitucional. (Revista Actualidad Laboral, 2006, p. 4-9)

En ese tenor, el legislador con el objeto de establecer en virtud del principio de solidaridad social y del cumplimiento de los deberes del Estado consagrados en la Constitución Política, un sistema de protección a las víctimas del secuestro y sus familias, los requisitos y procedimientos para su aplicación, sus instrumentos jurídicos, sus destinatarios, y los agentes encargados de su ejecución y control, expide el 26 de agosto de 2005 la ley 986 por medio de la cual se adoptan medidas de protección a las víctimas del secuestro y sus familias, y se dictan otras disposiciones. (Congreso de Colombia, Ley 986 de 2005)

La mencionada norma fue objeto de estudio por parte de la Corte Constitucional, la cual en sentencia C-394/07 ratificó la línea jurisprudencial iniciada con la sentencia T-015 de 1995, que garantiza a la familia de la persona secuestrada la continuidad en el pago de los salarios u honorarios que a ésta correspondan, con el fin de proteger el mínimo vital del núcleo familiar dependiente y todos aquellos derechos que dependen a su vez, de su satisfacción. De igual manera, se reiteró que esa protección cobija tanto a los servidores públicos como trabajadores particulares secuestrados, en desarrollo del principio de igualdad. En el mismo sentido, la corte destacó que al igual que en lo relativo al pleno disfrute del derecho a la educación de los hijos de quienes han perdido la libertad arbitrariamente, también se activa el deber del Estado consagrado en el artículo $2^{\circ}$ de la Constitución Política, así como el principio superior de solidaridad de los particulares (C.P., art. 95) a fin de que el acceso a dicho servicio público y el ejercicio del derecho no resulten seriamente afectados con el acaecimiento de la retención del padre o la madre del educando. Es 
Análisis Socio Jurídico del delito de secuestro en Colombia a partir de 1970

por esta razón que el Estado y la sociedad tienen el deber de propender por su goce efectivo en el caso de los hijos de quienes han sido víctimas de una conducta como el secuestro, la desaparición forzada o la toma de rehenes. (Corte Constitucional, Sentencia 394 de 2007)

\subsubsection{Ley 1436 de 2011.}

Fue expedida el 6 de enero de 2011 esta ley por medio de la cual se otorgan beneficios a las familias de las personas secuestradas con posterioridad al ejercicio de su cargo, Instrumentos de protección a las víctimas del secuestro y sus familia, que sitúan al secuestro como causal eximente de responsabilidad civil (interrupción de plazos y términos de vencimiento de obligaciones; no podrán ser incluidos en las centrales de información financiera; suspensión de procesos ejecutivos), instituyen el pago de salarios, honorarios y prestaciones sociales del secuestrado, garantizan la protección en materia de salud y asistencia psicológica y psiquiátrica, aseguran la continuidad en el acceso a la educación de los hijos y suspende términos en materia tributaria durante el tiempo de cautiverio y un período adicional igual a este. (Congreso de Colombia, Ley 1436 de 2011)

No obstante dentro del trámite legislativo, el gobierno nacional no estuvo de acuerdo con esta disposición por motivos netamente económicos, la Corte constitucional mediante sentencia C-866/10 declaró infundadas las objeciones gubernamentales presentadas al proyecto de ley No. 086 de 2008 -Senado-, 366 de 2009 -Cámara, "por medio de la cual se otorgan beneficios a las familias de las personas secuestradas con posterioridad al ejercicio de su cargo". (Corte Constitucional, Sentencia C 866 de 2010) 


\subsubsection{Acuerdo 124 de 2004 .}

El Acuerdo 124 de 2004 del Concejo de Bogotá, mediante el cual se establecen exenciones en materia tributaria sobre el inmueble, vehículo o establecimiento de comercio a nombre de la persona cautiva, su cónyuge o compañero/a permanente o sus padres, exclusivamente. En el mismo sentido la Secretaría de Hacienda del distrito capital sitúa una serie de beneficios de privilegios en materia tributaria con destino a las personas víctimas de secuestro y sus familias. (Concejo de Bogotá, Acuerdo 124 de 2004)

Como se ha visto a través de las exposiciones de los motivos tenidos en consideración para la expedición de estas normas, el secuestro ha sido un tema que ha venido oprimiendo y amedrentando al Estado y a la sociedad Colombiana debido a su frecuente utilización por parte de grupos al margen de la ley y dadas las consecuencias producidas, máxime cuando en muchas ocasiones se buscaba que las victimas fueran miembros de las fuerzas militares, agentes del Estado, o personalidades influyentes buscando esencialmente este impacto negativo de impotencia y desconfianza dentro de la colectividad.

Y es precisamente en defensa de esta seguridad pública, que el ente estatal reacciona ante el incremento de las estadísticas delictivas registradas, buscando en la mayoría de las veces en forma coyuntural, tomar medidas políticas y legislativas que se consideraron necesarias y eficaces para combatir los fenómenos criminales. Para lograr este objetivo se acudió a las figuras de aumento de penas, exclusión de beneficios y subrogados, creación de nuevas circunstancias de agravación y en algunos casos implementación de escenarios creación de alivio para las víctimas y sus familiares. 
Análisis Socio Jurídico del delito de secuestro en Colombia a partir de 1970

\section{Capítulo VI. Modalidades de Secuestro en Colombia 1970-2010}

El Manual de lucha contra el Secuestro publicado por Naciones Unidas, presenta una definición de secuestro, así como las diferentes modalidades que existen en el mundo para poder hacer frente con la mayor eficiencia a estos delitos. Según esta publicación los nueve tipos más comunes son el Secuestro con fines de extorsión, con fines políticos o ideológicos, el que se da entre grupos delictivos, o dentro de ellos, el vinculado a disputas familiares o domésticas, el Secuestro con fines de explotación sexual, el simulado o fraudulento, el Secuestro exprés, el secuestro virtual y La venta de la víctima de un secuestro a otro grupo. (Oficina de las Naciones Unidas Contra la Droga y el Delito, 2006)

En Colombia, el Centro Nacional de Memoria Histórica (2013) ha documentado 39.058 casos de secuestro ocurridos entre los años de 1970 a 2010, siendo los más frecuentes aquellos que tuvieron motivaciones políticas y económicas. Dentro de ellos se tiene noticia que 16.001 han tenido motivación económica y 2.332 han tenido motivación política. Dentro de los económicos 9.447 fueron cometidos por las FARC, 7.362 por el ELN, Y 7.595 por delincuencia común y delincuencia organizada, y en cuanto a la motivación política LAS FARC cometieron 934 casos, el ELN en 858 casos, el M 19 en 66 casos, narcotráfico en 12 y paramilitares en 131 casos. 
Gráfica 3. Secuestros $1970-2010$

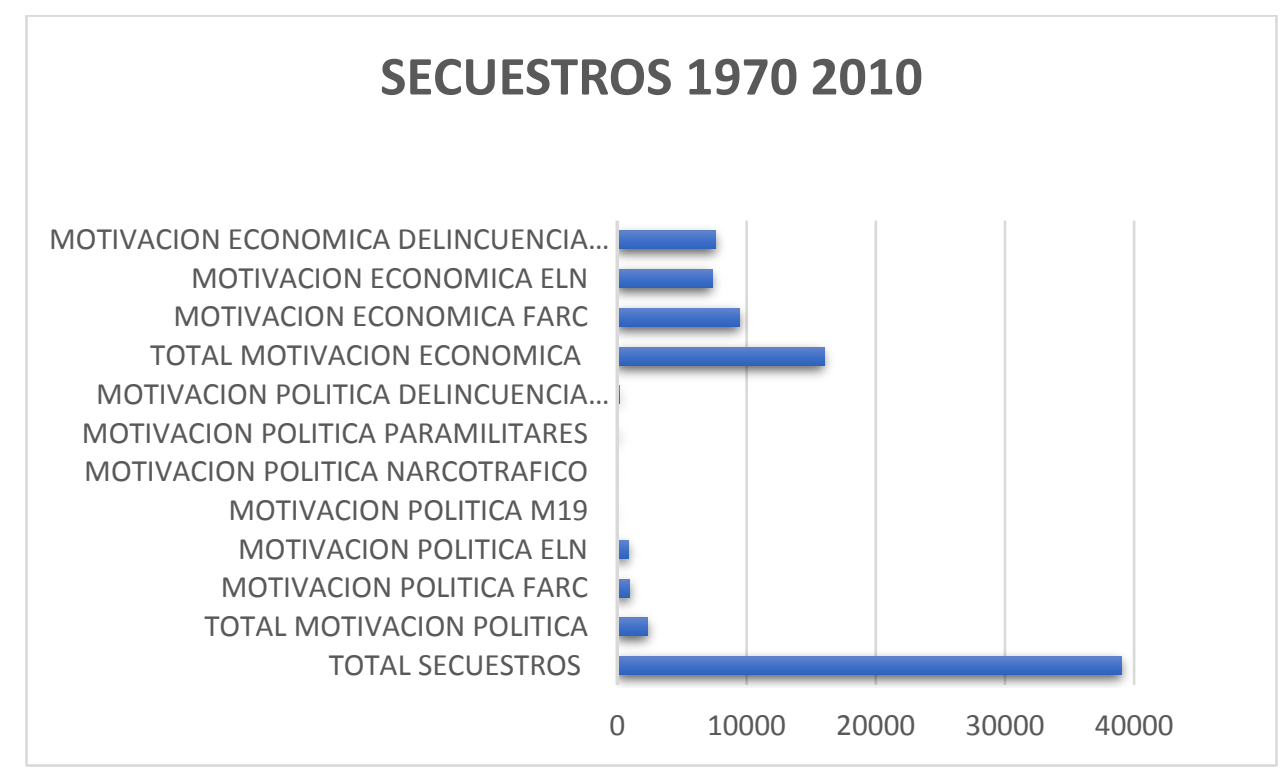

Fuente: Datos tomados del Centro Nacional de Memoria Histórica, 2013 (Elaboración Propia, 2018)

Como vemos la mayor cantidad de casos de secuestro presentados en estas cuatro décadas, pueden sintetizarse en la motivación política y la económica, por lo cual se considera pertinente hacer un análisis de cada una de estas modalidades.

\subsection{Motivación Política del Secuestro}

Los datos obtenidos en el estudio sobre secuestro en Colombia "Una Verdad Secuestrada", permiten verificar que las Farc han tenido una participación significativa en los secuestros dentro del territorio colombiano. Se ha identificado que durante el período 1970-2010 estuvieron involucradas como autoras presuntas en 9.447 secuestros y como autoras confirmadas en 3.325. En efecto las guerrillas han utilizado 
Análisis Socio Jurídico del delito de secuestro en Colombia a partir de 1970

el secuestro como estrategia de presión política, particularmente en el marco de negociaciones de paz con el Gobierno. Durante los Acuerdos de La Uribe —entre 1984 y 1987—, se estableció una tregua entre las Farc y el gobierno de Belisario Betancur que implicó un cese al fuego, el compromiso de la guerrilla de dejar el secuestro y del Gobierno de impulsar reformas en el orden político, social y económico. (Centro Nacional de Memoria Histórica, 2013, p. 169)

En este contexto, las Farc cometen en promedio 34 secuestros anuales entre 1984 y 1987. Tras la ruptura del cese al fuego, incrementan sus secuestros de carácter político como una forma de manifestar su fortalecimiento frente al Estado y en consecuencia, en 1988 se registra el $71 \%$ del total de secuestros políticos de la década. Revela el estudio que la dicotomía entre el discurso y el accionar de las Farc se reflejó en la promoción de una creciente expansión militar y la consolidación de la Unión Patriótica como su brazo político, surgiendo la llamada 'combinación de todas las formas de lucha', lo cual genera un sinsabor en la opinión pública, por cuanto la sociedad esperaba un verdadero compromiso por parte del grupo guerrillero con el abandono de la lucha militar y el fortalecimiento de la actividad política. (Centro Nacional de Memoria Histórica, 2013, p. 171)

Así las cosas, las cifras estudiadas, permiten afirmar que el secuestro es utilizado por las guerrillas como una herramienta en función de su estructura militar, justamente el estudio permite aseverar que la práctica del secuestro por parte de las guerrillas específicamente las FARC, permitió fortalecerlas en aspectos tales como su capacidad logística y la consolidación de la estructura de mando a la vez que este delito fue utilizado como una muestra a los combatientes de menores rangos de la posibilidad 
Análisis Socio Jurídico del delito de secuestro en Colombia a partir de 1970

real y cercana de controlar y humillar a sus blancos ideológicos y militares. En ese mismo sentido, se puede aseverar que el secuestro de miembros de la Fuerza Pública y de líderes políticos se utilizó como una herramienta para la consolidación de un discurso político en el que se convierte al secuestrado en prisionero de guerra de un actor político que se considera a sí mismo legítimo, al disputarle el poder a un Estado al cual declara ladrón, corrupto, injusto y opresor. (Centro Nacional de Memoria Histórica, 2013, p. 175)

Gráfica 4. Secuestro Prisioneros de Guerra

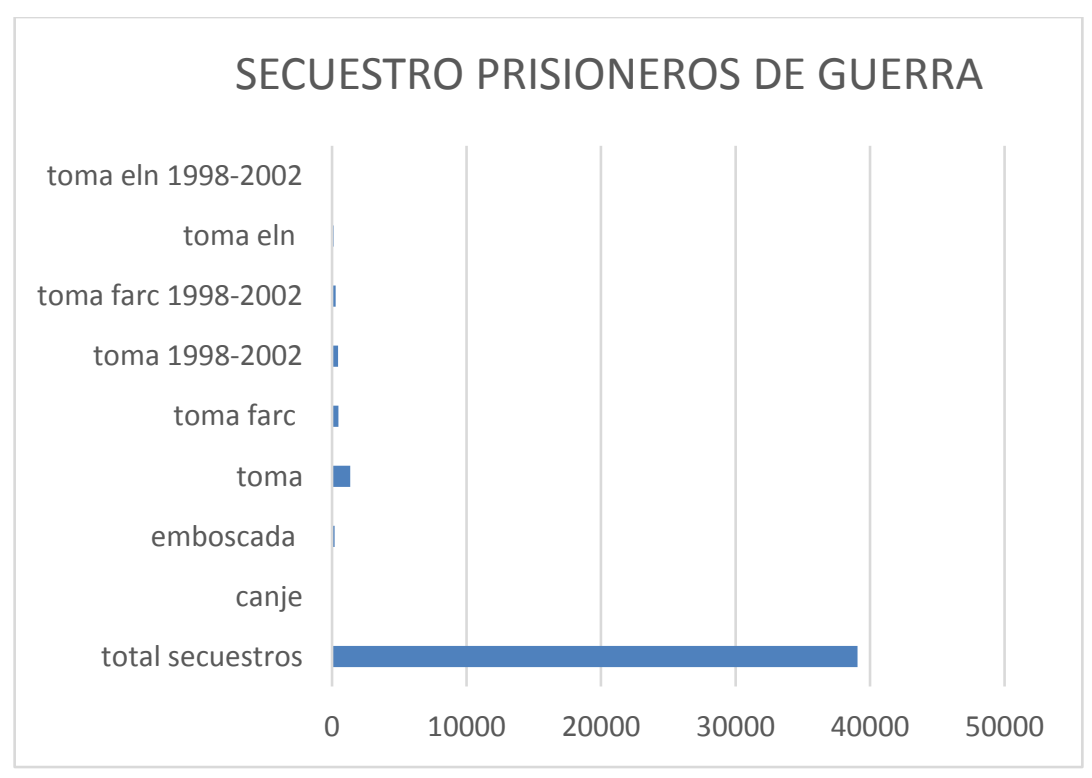

Fuente: Datos tomados del Centro Nacional de Memoria Histórica, 2013 (Elaboración propia, 2018)

Así, podemos observar una clara intención de las FARC de secuestrar miembros de la fuerza pública, con miras a lograr los llamados "CANJES" que no eran otra cosa que el intercambio de secuestrados pertenecientes al Estado por miembros de las FARC privados legalmente de la libertad por esta razón este fenómeno también fue llamado "INTERCAMBIO HUMANITARIO", 
el cual fue propuesto por el grupo guerrillero con gran aceptación por parte de la sociedad civil y con reacción negativa de la clase política.

Medios de prensa nacionales han relacionado los casos de secuestro más connotados ocurridos en dicha fase, así:

1996- 30 de agosto: Guerrilleros atacan la base militar de "Las Delicias", en la Amazonía, donde matan a 27 militares y secuestran a 60 que son liberados meses después.

1997- 21 de diciembre: Las FARC atacan una base del Ejército en el cerro de Patascoy, suroeste, mueren 10 militares y 18 son secuestrados.

1998- 3 de marzo: Un ataque en El Billar (Caquetá) deja 65 militares muertos y 43 secuestrados.

- 3 de agosto: Las FARC atacan una base antinarcóticos en Miraflores (Guaviare), matan a 40 policías y militares y secuestran a 56 .

- 1 de noviembre: La guerrilla ocupa Mitú, capital del departamento de Vaupés, mueren 16 policías y militares y 61 son secuestrados.

1999- 7 de enero: Las FARC negocian con el presidente Andrés Pastrana (1998-2002) en una "zona de distensión" (desmilitarizada) de más de 43.000 kilómetros cuadrados en el sur del país. (Caracol, 2011)

Para el brazo militar más radical de las FARC, representado en su momento por alias "Mono Jojoy", dicho canje ha debido presionarse militarmente porque no se ha logrado ningún acuerdo de larga duración. Refiriéndose al respecto - en el marco de las negociaciones de paz del 
Análisis Socio Jurídico del delito de secuestro en Colombia a partir de 1970

Caguán - el "Mono Jojoy" dio unas explosivas declaraciones que dejaron entrever las intenciones de las FARC de establecer una "política" al interior de la organización que promoviera el secuestro de miembros de las Fuerzas Armadas y de funcionarios públicos, y permitiera a este grupo guerrillero presionar y deslegitimar al Estado en pro de la liberación de guerrilleros detenidos en las cárceles colombianas, e incluso en el exterior, como en el caso de "Simón Trinidad":

"Si no se puede la ley de canje, tocara que algunos de la clase política acompañen a los soldados, para que salgan en el canje. Es la única forma. Si no quieren por las buenas tocara por otros medios. Pero esa ley debe salir. Habrá que traer políticos como hicieron con el hermano de Gaviria. Porque solo entonces les pusieron atención y los llevaron a Cuba y los canjearon (...) si [la solución] se prolonga en el tiempo, cada semana o cada día que pase habrá más prisioneros. Entonces, lo mejor es solucionarlo inmediatamente. Además, lo poco que tenemos para dar son los prisioneros. Entregarlos y que nos entreguen los nuestros. Asi de facilito." (El Espectador, 2016)

Indiscutiblemente se puede evidenciar una táctica de este grupo subversivo de secuestrar figuras políticas con un doble fin: primero, presionar al Estado colombiano y, segundo, publicitar un discurso político a la vez que su poderío y capacidad militar frente a la debilidad del Estado en sus zonas históricas de control, máxime cuando a dichas retenciones se les dio un gran despliegue mediático por tratarse de personalidades públicas. Se debe destacar que entre 2000 al 2002 se presentaron 159 secuestros políticos atribuidos a las Farc, de los 926 secuestros políticos de los que se tiene noticia cometió ese grupo guerrillero entre 1970 y 2010. Veamos algunos de los más significativos: 
Cuadro 3. Secuestros atribuidos a las Farc

\begin{tabular}{|c|c|}
\hline FECHA & SECUESTRO \\
\hline 5 de agosto de 2000 & Las FARC secuestran al congresista Óscar Tulio Lizcano. \\
\hline 4 de diciembre de 2000 & $\begin{array}{l}\text { Las FARC secuestran al ex canciller Fernando Araújo en } \\
\text { Cartagena. }\end{array}$ \\
\hline 15 de julio de 2001 & $\begin{array}{l}\text { Las FARC secuestran al entonces gobernador del Meta, Alan } \\
\text { Jara, cuando viajaba en un vehículo de la ONU. }\end{array}$ \\
\hline 10 de junio de 2001 & $\begin{array}{l}\text { Las FARC secuestran al senador Luis Eladio Pérez Bonilla en } \\
\text { Nariño. }\end{array}$ \\
\hline 26 de julio de 2001 & $\begin{array}{l}\text { Asalto a un edificio en Neiva y secuestran a los dos hijos del } \\
\text { senador Jaime Lozada, a su esposa, Gloria Polanco, y a doce } \\
\text { vecinos. Se atribuyó el hecho a las FARC. }\end{array}$ \\
\hline 28 de agosto de 2001 & $\begin{array}{l}\text { El congresista Orlando Beltrán Cuéllar es secuestrado por las } \\
\text { FARC en Huila. }\end{array}$ \\
\hline $\begin{array}{l}10 \text { de septiembre de } \\
2001\end{array}$ & $\begin{array}{l}\text { Las FARC secuestran en Huila a la congresista Consuelo } \\
\text { González de Perdomo. }\end{array}$ \\
\hline $\begin{array}{l}30 \text { de septiembre de } \\
2001\end{array}$ & $\begin{array}{l}\text { Muere en una operación de rescate la ministra de Cultura, } \\
\text { Consuelo Araújo, varios días después de ser secuestrada en el } \\
\text { norteño departamento del Cesar. }\end{array}$ \\
\hline 20 de febrero de 2002 & $\begin{array}{l}\text { Guerrilleros de las FARC obligan al piloto de un avión a } \\
\text { aterrizar en una carretera del Huila y secuestran a tres } \\
\text { ocupantes, entre ellos el senador Jorge Eduardo Gechem } \\
\text { Turbay. }\end{array}$ \\
\hline 23 de febrero de 2002 & $\begin{array}{l}\text { La candidata presidencial Íngrid Betancourt, y su compañera de } \\
\text { fórmula, Clara Rojas, son secuestradas por las FARC. }\end{array}$ \\
\hline 21 de abril de 2002 & $\begin{array}{l}\text { Las FARC secuestran al gobernador de Antioquia Guillermo } \\
\text { Gaviria, y a su asesor de paz, Gilberto Echeverri. }\end{array}$ \\
\hline 11 de abril de 2002 & $\begin{array}{l}\text { Las FARC asaltan la Asamblea Departamental del Valle del } \\
\text { Cauca, en Cali, y secuestran a doce diputados. }\end{array}$ \\
\hline
\end{tabular}

Fuente: Datos tomados del Espectador, 2009 (Elaboración propia, 2018) 
Análisis Socio Jurídico del delito de secuestro en Colombia a partir de 1970

Esta cifra de secuestros acaecidos entre 2000 y 2002 coincide con la zona de distensión del Caguán que inicia el 4 de octubre de 1998 con la expedición por parte del Presidente de la República, del Decreto con el cual ordenó el despeje militar de los municipios San Vicente del Caguán, Uribe, Macarena, Vistahermosa y Mesetas, ubicados en los departamentos de Meta y Caquetá. Esta concesión se formaliza el 7 de noviembre de ese año y termina el 20 de febrero de 2002 cuando Guerrilleros de las FARC obligan al piloto de un avión a aterrizar en una carretera del Huila y secuestran a tres ocupantes, entre ellos el senador Jorge Eduardo Gechem Turbay. (El Tiempo, 2009)

Para el politólogo Ricardo García Duarte el secuestro político tiene una dimensión instrumental y como tal se orienta en tres posibles direcciones: hacer llegar un mensaje, obtener por presión un objetivo particular o ejecutar un castigo. En consecuencia, hay secuestros de propaganda, de chantaje y de castigo donde los primeros se sitúan en el plano de la comunicación, el segundo reemplaza o complementa otros instrumentos de presión, como la acción de masas o el combate militar, para conseguir del Estado, de una institución o de una empresa, alguna reivindicación corporativa, una petición política o la libertad de unos prisioneros y el tercero es el vehículo para desarrollar una venganza contra el "régimen enemigo", en la persona de alguien que presuntamente lo represente.

Pueden existir casos en los que un secuestro político va más allá de la simple publicidad y se concentra en el chantaje alrededor de una reivindicación o un objetivo particular, la sustracción de la libertad de una o varias personas viene a veces acompañada por la criminal amenaza de muerte sobre las víctimas del secuestro. Sobre tal punto se cita el ejemplo de este tipo de operativos fue la toma de rehenes en la Embajada Dominicana en Bogotá por el M-19, con lo cual este pretendía que el Gobierno liberara a sus prisioneros, detenidos en las cárceles del Estado. A pesar 
Análisis Socio Jurídico del delito de secuestro en Colombia a partir de 1970

de las amenazas que pesaron sobre la vida de los diplomáticos rehenes, el jefe de la guerrilla, Jaime Bateman, entendió que si bien el Gobierno no accedía a sus demandas principales, el propósito intermedio de publicidad había sido alcanzado, y se podía dar salida al hecho con una negociación que pusiese a salvo la vida de los secuestrados, y así mismo la libertad de los guerrilleros que ejecutaron el operativo, acogidos por otro país.

En este orden de ideas los secuestros de políticos perpetrados por las FARC pasaron de ser un medio para presionar el intercambio de prisioneros y pasaron a ser un ejercicio delictuoso y violento dotado de su propia dinámica que trataba de justificarse por sí misma, generando un prolongado suplicio para las víctimas y sus familiares, por cuanto estos fueron convertidos por la guerrilla en prisioneros de guerra al igual que los militares capturados en combate, dándoles la posición de "canjeables" con alto grado de riesgo para su vida dadas las paupérrimas condiciones en que se encontraban en los más inhóspitos parajes de nuestra geografía nacional. (Razonpublica, 2009)

De acuerdo con los datos obtenidos en el estudio "Una verdad secuestrada", las FARC han tenido una participación significativa en los secuestros dentro del territorio colombiano. Se ha identificado que durante el periodo 1970 - 2010, las FARC estuvieron involucradas como autor presunto en 9.447 secuestros y como autor confirmado en 3.325. Una de las consecuencias del proceso de masificación del secuestro en el país, es que la sociedad colombiana vio cómo este flagelo no sólo afecta a las élites económicas y políticas, sino a toda lo sociedad.

Frente a esto se ha acudido a la protesta social a través de marchas como la del 4 de febrero de 2008, donde la sociedad civil pidió una vez más al gobierno y a la guerrilla de las FARC la liberación de los secuestrados. Los ciudadanos han mostrado su rechazo a esta práctica y a su principal autor: Las Fuerzas Revolucionarias de Colombia - FARC, descontento que se derivó de 
la poca voluntad de paz de este grupo durante los diálogos del Caguán, y la incursión de las FARC en actividades de narcotráfico que puso en entredicho la veracidad de su discurso revolucionario ante la opinión pública nacional e internacional.

Las manifestaciones de repudio contra las FARC nacen fundamentalmente en las zonas urbanas del país, y es promovida por una población que siente cada vez más cerca el conflicto armado interno por medio de la masificación de secuestros en el territorio colombiano, y las múltiples afectaciones a individuos no sólo de las élites del país, sino de la clase media, dada la diversificación de los perfiles de los secuestrados. Esto conlleva a una reacción masiva contra las FARC, principal autor de secuestros durante el periodo de Masificación (1996-2000), quienes comenten los secuestros más visibles por su trascendencia política o por su duración, a saber, aquellos cometidos contra funcionarios y figuras públicas como Íngrid Betancourt, Jorge Eduardo Géchem, Fernando Araujo, Alan Jara y Guillermo Gaviria, entre otros. (El Espectador, 2016)

En este contexto desfavorable para la imagen de las FARC como grupo revolucionario, se suma el cruel asesinato cometido el 18 de junio de 2007 en el cual resultaron victimas los diputados de la asamblea del valle que habían sido secuestrados el 11 de abril de 2002. En efecto, según el relato del único sobreviviente Sigifredo López, las FARC procedieron a matarlos en el campamento donde los tenían cautivos, en medio de la confusión que les produjo la llegada de otro grupo de la misma guerrilla; y bajo la pulsión de la "paranoia" y la "cobardía" que se desató en esas circunstancias. Posteriormente las FARC ya en medio del desarrollo de un proceso de PAZ con el gobierno nacional Colombiano "pidieron también perdón a toda la sociedad vallecaucana, reconocieron que no fue un secuestro contra los 12 hombres, sino contra la institucionalidad" (El Tiempo, 2016) 
Análisis Socio Jurídico del delito de secuestro en Colombia a partir de 1970

En ese trágico escenario se destacaba en ese momento el desprestigio que ostentaba las FARC ante la sociedad que veía como los propios secuestradores asesinaban a los secuestrados, así se desvanecía el propósito de estos de situar al secuestro como acción con fin político, y en consecuencia deciden realizar nuevamente procesos de liberaciones unilaterales, que se habían iniciado en junio de 2001, cuando se encontraban adelantando negociaciones de paz con el entonces presidente Andrés Pastrana, en aquella ocasión se llegó a un "acuerdo humanitario" por el que fueron liberados más de 350 militares y policías que estaban en manos de las Farc y, a cambio, 14 insurgentes salieron de la cárcel.

En 2002 la guerrilla elaboró una lista que llamaron "canjeables", la cual para ese momento sumaba unos sesenta, dentro de ellos seis congresistas, doce diputados regionales, la excandidata presidencial Ingrid Betancourt y la también política Clara Rojas, tres estadounidenses y decenas de soldados y policías, desafortunadamente este intento de canje no produjo efectos positivos sin que este canje se produjera. Posteriormente en el año 2007, se aceptó la mediación del presidente venezolano Hugo Chávez, el cual fue cancelado por el presidente Álvaro Uribe en noviembre del mismo año luego de que el venezolano se comunicara con el comandante del Ejército colombiano, pese a la oposición del gobierno colombiano de que mantuviera contactos directos con mandos militares. (rfi español, 2007)

Luego gracias a un gesto que fue denominado por ellos como de "desagravio" hacia Chávez, los guerrilleros liberaron a dos rehenes en enero de 2008 y a partir de ahí se dieron una serie de liberaciones hasta 2010, cuando anunciaron la puesta en libertad de otros cinco secuestrados como gesto de desagravio, hacia Piedad Córdoba quien había sido destituida de su cargo como senadora. Dichas liberaciones, las últimas hasta ahora y que finalmente fueron seis, se produjeron en febrero de 2011. 
Análisis Socio Jurídico del delito de secuestro en Colombia a partir de 1970

Pese a ello, el 26 de noviembre de 2011 las FARC asesinaron a cuatro secuestrados, los policías Edgar Yesid Duarte Valero, Elkin Hernández Rivas y Álvaro Moreno, y el sargento mayor del Ejército José Libio Martínez en represalia por una supuesta operación militar de rescate, la muerte de estos retenidos que llevaban cautivos más de diez años llevó a convocar la movilización ciudadana, en la cual se reclamaba la libertad de hasta 103 secuestrados y desaparecidos, lo cual generó una serie de movimientos organizados no solo a nivel nacional, sino de América Latina, Estados Unidos y Europa en forma de marchas espontáneas y actos pacíficos, todos ellos coincidentes en expresar su rechazo a las FARC. Ante estas manifestaciones, esta guerrilla anunció que continuarían las liberaciones unilaterales. (20 minutos, 2011)

Para ese mismo mes de diciembre de 2011 las FARC anunciaron la entrega unilateral de tres uniformados y dos concejales que habían sido secuestrados en diferentes hechos entre 2007 y 2010, para lo cual se realizó un operativo humanitario en el que participó la ex senadora Piedad Córdoba, dicha diligencia estuvo en riesgo de ser cancelada debido a que las FARC secuestraron a dos trabajadores de la empresa Cartón de Colombia en la localidad de El Tambo, en el departamento de Cauca. Para ese entonces el presidente Santos calificó de inaceptable" el "doble juego y la doble moral" de los guerrilleros que en un supuesto gesto humanitario decidieron liberar a uno de los rehenes políticos, mientras que por otro lado privan a otras personas de la libertad. No obstante, el mandatario decidió avanzar con la entrega para no dañar la emoción y frustrar la esperanza de las familias de esos secuestrados. (Notimérica, 2011)

Para el año 2016, la Fundación País Libre revisó todas las bases de datos de secuestrados que no habían sido liberados, utilizando el histórico de bases de datos que tenían además de bases de datos de diferentes organizaciones, hallando 182 casos atribuidos a las Farc en la que los secuestrados que nunca retornaron con su familia y cuya situación se desconoce, a los cuales se 
Análisis Socio Jurídico del delito de secuestro en Colombia a partir de 1970

llamaron "desaparecidos". (Colombiacheck, 2018). Ante esta situación, en las negociaciones de paz entre el gobierno del presidente JUAN MANUEL SANTOS y las FARC que tuvieron como resultado la firma del Acuerdo para la Terminación Definitiva del Conflicto en Bogotá el 24 de noviembre de 2016, ratificado por el congreso Nacional 29 y 30 de noviembre del mismo año, se acordó crear la Unidad para la Búsqueda de Personas dadas por Desaparecidas (Ubpd), con el objetivo de establecer lo ocurrido a las víctimas calificadas como desaparecidas por consecuencia del conflicto armado, la cual hace parte del Sistema Integral de Verdad, Justicia, Reparación y No Repetición (Sivjrnr). Según el Acuerdo, la Ubpd recolectará información acerca de los secuestrados entre el Gobierno, las Farc y organizaciones como País Libre, Fevcol y el Movimiento de Víctimas de Crímenes del Estado (Movice), entre otras organizaciones de víctimas, con el fin de realizar una búsqueda ágil. (Alto comisionado para la paz, 2016)

\subsection{Secuestro extorsivo periodo 1996-2003}

El periodo entre el 1996 y el 2003 se puede mencionar como el más caótico en materia de secuestros en nuestro país, estudio realizado por el departamento nacional de planeación de Colombia, destacan que en ese lapso se reportaron 13.616 secuestros extorsivos en Colombia, es decir, un promedio de 1.702 secuestros al año (4,7 secuestros diarios), habiéndose cometido un secuestro cada cinco horas.

Así las cosas, en este periodo la tasa de crecimiento promedio anual en materia de secuestro fue de 15,8\%, siendo el año con menor registros 1996 (961 casos) y el de mayor número de casos 1999 (2.675 personas). Destaca el departamento nacional de planeación, la ocurrencia de dos

periodos: el primero de ellos entre 1996 y 1999, caracterizado por un crecimiento significativo del 
Análisis Socio Jurídico del delito de secuestro en Colombia a partir de 1970

fenómeno y el segundo a partir de 2000 con una tendencia más bien decreciente (desciende 3,2\% en promedio anual), aunque en el año 2002 el número de secuestros crece con respecto al 2001 un 83\%, la tendencia decreciente del período continúa, disminuyendo en el año 2003 los secuestros disminuyen un $22 \%$. Sobre la participación de las autodefensas ilegales en esta clase de ilícitos, enfatiza el estudio que sólo participan con un 3.8\% de los secuestros, argumentando que esta participación casi débil de las autodefensas en el número total de casos de secuestros en Colombia, se debe a varias razones, entre ellas, una posible dificultad en discernir aquellos secuestros cometidos por la delincuencia común, su menor organización centralizada y homogénea, y la falta de una ideología que legitime el secuestro.

Gráfica 5. Número total de secuestros extorsivos a nivel nacional 1996-2003

\section{Número total de secuestros extorsivos a nivel nacional $1996-2003$}

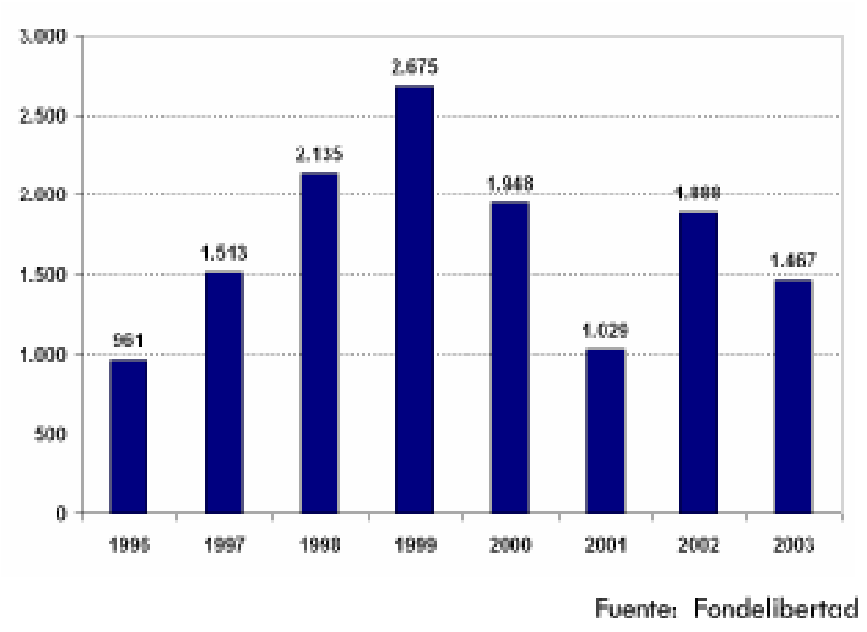

\section{Contenido:}

\begin{tabular}{ll}
\hline $\begin{array}{l}\text { Definición } \\
\text { Comportamiento de la } \\
\text { variable }\end{array}$ & 1 \\
\hline Autor & 2 \\
\hline Distribución regional & 3 \\
\hline Formo de secuestro & 5 \\
\hline Condición laboral & 5 \\
\hline Sector económico & 6 \\
\hline Otras carocteristicas & 7 \\
\hline Tiempo de cautiverio $y$ dinero & 8 \\
\hline Resumen histórico & 8 \\
\hline Resumen & 9
\end{tabular}

Fuente: Departamento Nacional de Planeación, 2003 
Gráfica 6. Evolución de la participación del total de secuestros extorsivos según autor 19962003
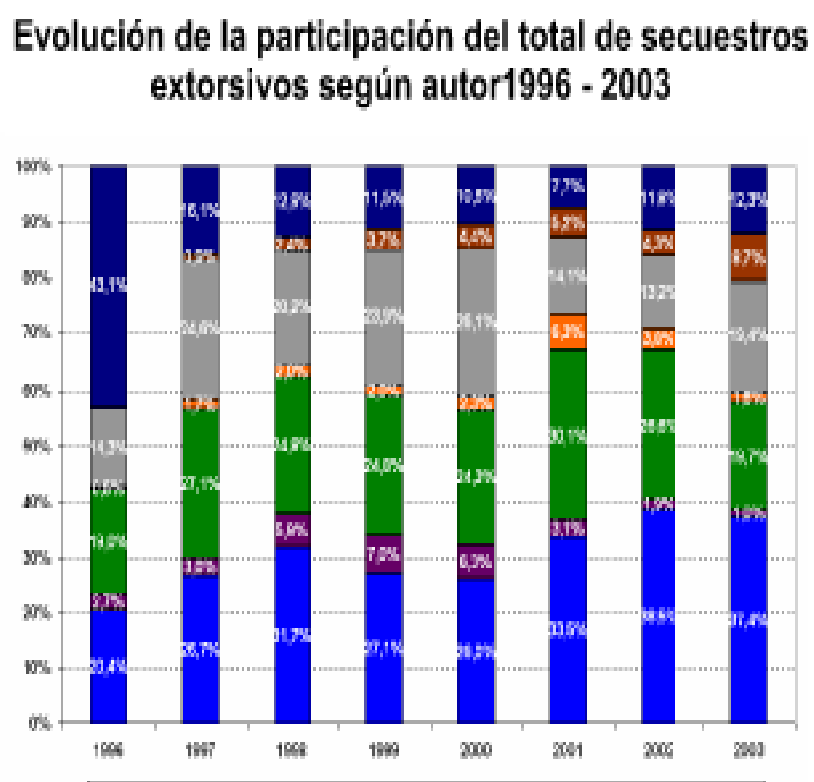

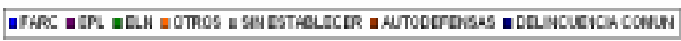

Fuente: Fondelibertad
Participación del total de secuestros extorsivos según autor1996 - 2003

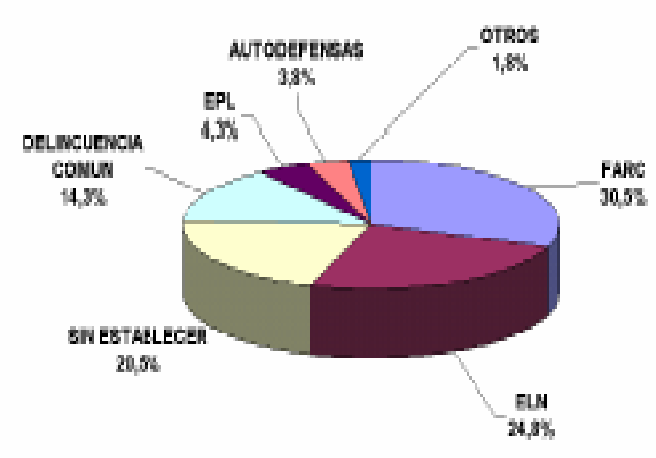

Fuenter Fondelibertod

Fuente: Departamento Nacional de Planeación, 2003

Por otra parte, el Centro Nacional de Memoria Histórica afirma que en 1990 se presenta un fortalecimiento en la incursión de nuevos actores en la práctica del secuestro, es así como durante el periodo que va de 1990 hasta 1995 se presentó un ascenso tanto del conflicto armado como del secuestro. Del estudio de las cifras se puede evidenciar que el secuestro en este año al pasar de 280 a 1.122 casos, lo que podría explicarse a partir del fortalecimiento del Ejército de Liberación Nacional - ELN como actor en el marco del conflicto, gracias, en parte, a la práctica del secuestro. Aunado a lo anterior se puede referir lo que algunos tratadistas denominan como "la profesionalización del secuestro", fenómeno que tiene que ver con el inicio por parte de otros grupos armados al margen de la ley como lo pueden ser el M19 (a pesar de su desmovilización), 
Análisis Socio Jurídico del delito de secuestro en Colombia a partir de 1970

el Ejército Popular de Liberación - EPL y el Movimiento Armado Quintín Lame - MAQL. (Centro Nacional de Memoria Histórica, 2013, p. 32)

Posteriormente se presenta una etapa de masificación del secuestro (periodo 1996 -2000) el cual coincide con un incremento del conflicto armado y de una profunda crisis del Estado, dentro del cual es clara la presencia de las FARC como el actor con mayor volumen de secuestros en este periodo, y de un generalizado aumento de los niveles de violencia en Colombia ya que se pasó de 4.354 secuestros en el Escalamiento a 13.548 en la fase de Masificación.

Gráfica 7. Secuestros 1996-2003

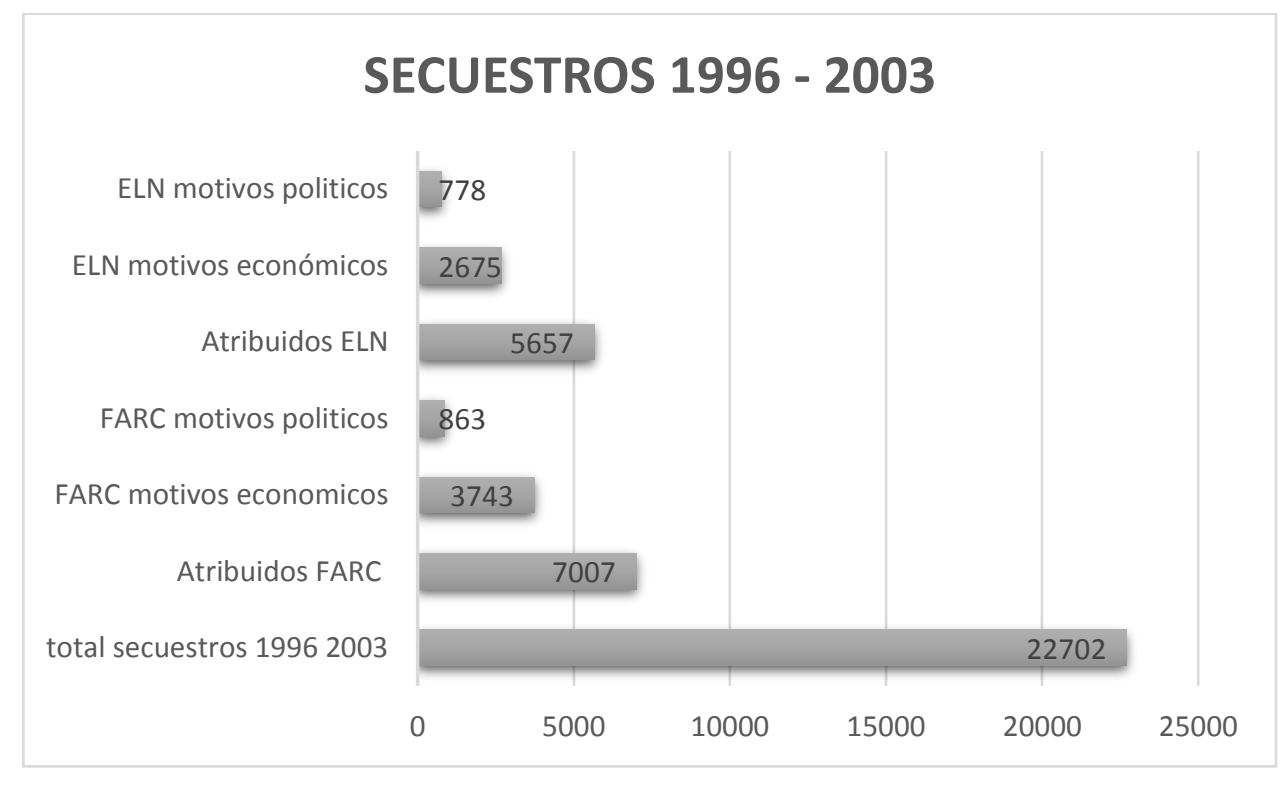

Fuente: Datos tomados del Centro Nacional de Memoria Histórica, 2013 (Elaboración Propia, 2018)

Según Echandia (2004):

Durante la fase de Escalamiento se presentó un aumento del 93\% en el número de secuestros en comparación con la etapa de Inicios, al pasar de 2.253 a 4.354. En este 
Análisis Socio Jurídico del delito de secuestro en Colombia a partir de 1970

periodo, los grupos guerrilleros, particularmente las FARC y el ELN, aprovecharon el marco de oportunidad para crecer y fortalecerse a nivel militar y político, incrementando la comisión de secuestros, principalmente extorsivos, y además entraron a formar parte directa del complejo entramado que constituye la infraestructura del negocio del narcotráfico en Colombia. (Citado de Centro Nacional de Memoria Histórica, 2013, p. 34)

Para Pizarro (2004), el secuestro, pese a no ser la única actividad a la que recurrieron las agrupaciones guerrilleras, funcionó como un mecanismo efectivo en el marco de su estrategia expansiva.

(...) [al ver consolidadas sus áreas de influencia en las regiones de colonización], da un salto hacia regiones con valor estratégico en el plano económico, con objeto de buscar ya sea el control directo en la explotación de recursos naturales o la extorsión a sus productores (Pizarro, 2004, p. 92)

Estas afirmaciones encuentran eco en un estudio realizado por la UIAF (ente estatal cuyas siglas significan UNIDAD DE INTELIGENCIA Y ANALISIS FINANCIERO) que fuera revelado en 1993 por la revista semana como "secreto", allí se destaca que Aparte de los dividendos derivados del narcotráfico, otra fuente de ingresos de las Farc es el secuestro. Según datos de entidades oficiales que hicieron seguimientos concretos a cada caso, con promedios que oscilan entre 140 y 160 millones de pesos recibidos por el pago del rescate de cada secuestrado, durante 2003 las cuadrillas de las Farc entregaron al Secretariado del grupo terrorista 88.560 millones de pesos. (Revista Semana, 2005) 
Análisis Socio Jurídico del delito de secuestro en Colombia a partir de 1970

Para el Centro Nacional de Memoria Histórica el incremento de secuestros en este período se explica por dos razones concretas: la primera y más sombría es el uso de las llamadas pescas milagrosas por los grupos armados ilegales y la segunda de ellas el control territorial que obtuvo las FARC en medio de las negociaciones de paz con el gobierno de Andrés Pastrana, y el uso del secuestro como herramienta de presión política durante las mismas. Recalca el estudio que desde 1996 el país fue testigo de la debilidad institucional y la ausencia del Estado en una parte del territorio nacional. La cesión de la zona de despeje en San Vicente del Caguán contribuyó a ahondar la crisis y aumentar la capacidad operativa de las FARC, lo que permitió que el grupo guerrillero fuera capaz de mantener grandes volúmenes de secuestrados, concluyendo que durante los diálogos del Caguán realizados entre 1998 y 2002, las FARC cometieron 5.351 secuestros, entre ellos 659 con motivación política y 2787 con motivaciones económicas

Gráfica 8. Secuestros atribuidos a grupos ilegales

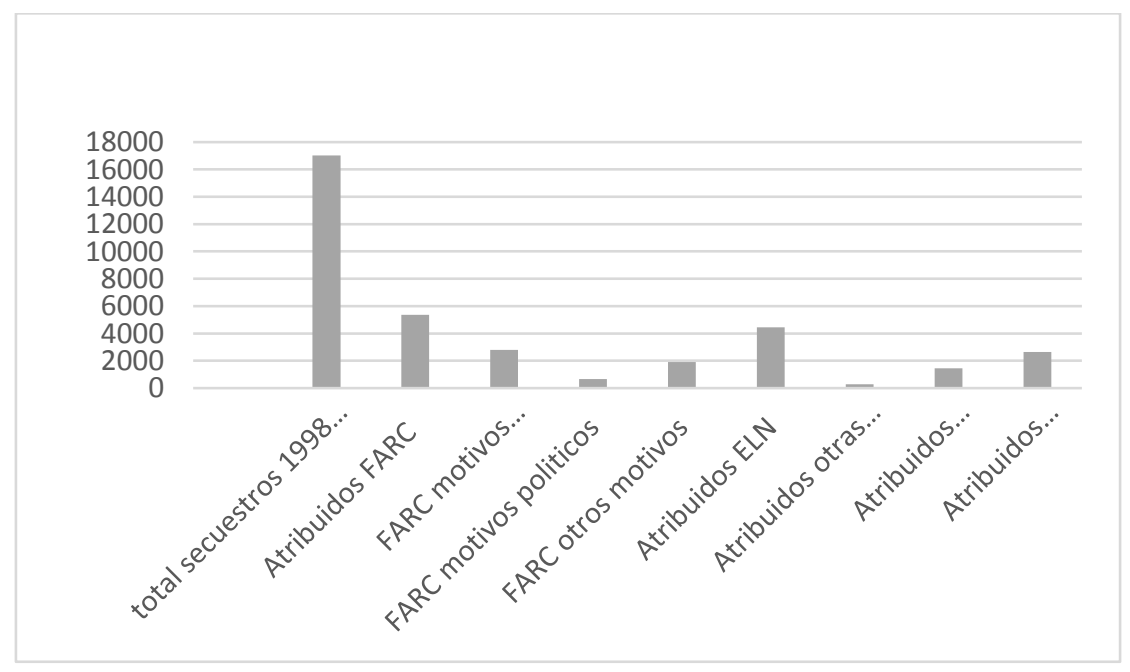

Fuente: Datos tomados del Centro Nacional de Memoria Histórica, 2013 (Elaboración Propia, 2018) 


\subsection{Pescas Milagrosas}

El drama de la familia Aguachica Daza comenzó el 2 de julio pasado en una carretera cesarense. Lo que se suponía sería un paseo recreativo, se convirtió en un secuestro múltiple. Sara Emilia Daza, su hija Cristina y su primo Julio César Daza salieron para Santa Marta a pasar el puente festivo y fueron secuestrados por el frente 6 de Diciembre del Eln, entre los corregimientos de Aguas Blancas y Mariangola, a 20 kilómetros de Valledupar. Las dos mujeres fueron liberadas posteriormente, pero el primo sigue cautivo. Ellas aseguran que jamás volverán a viajar por carretera. (El Tiempo, 2000)

Este es un relato que aparece registrado en el periódico el tiempo del 20 de julio de 2000 en el cual se deja ver el drama que corrían las personas que transitaban por las vías de Colombia; para la época según país libre y los grupos Gaula, no existía una carretera donde los viajeros no se sintieran amenazados por el secuestro.

Era tal la situación de zozobra que se tenían carreteras "vedadas" tales como la vía Medellín-Bogotá cuyo trayecto Cocorná-San Luis era el preferido por el frente Carlos Alirio Buitrago, del Eln, para los retenes ilegales, en la via al llano, el sitio Monterredondo, entre Cáqueza y Guayabetal (Cundinamarca), en la costa la vía San Juan Nepomuceno-Sincelejo; El Carmen de Bolívar-Zambrano, y El VisoMarialabaja, en Valledupar la via hacia Badillo, Valledupar-Riohacha y ValleduparBucaramanga, pasando por Bosconia, El Copey y San Alberto, en la zona bananera del Magdalena la vía Ciénaga-Fundación y en sucre la vía Sincelejo-Ovejas. En Santander y Norte de Santander, los sitios neurálgicos eran Ocaña-Cúcuta, Bucaramanga-Pamplona, Ocaña-Aguachica y Bucaramanga-San Alberto (sur del 
Análisis Socio Jurídico del delito de secuestro en Colombia a partir de 1970

Cesar), en el Eje Cafetero, las vías Manizales-Medellín y Pereira-Medellín, y el Huila las vías Neiva-San Vicente del Caguán; Campoalegre-Algeciras; Neiva-Algeciras .

En las "pescas milagrosas" se buscaba interceptar por parte de los grupos subversivos a una persona o un grupo de personas en una vía sin hacer previa inteligencia. Rubio (2007) destaca que en la página web de Medios para la Paz, cuya misión es "propiciar el ejercicio ético y responsable del periodismo" no se ofrece ningún reparo a la utilización del desafortunado término, sino que implícitamente se propone su formalización al definir como la ocurrencia de retenes sorpresivos para secuestrar a población civil que transita en forma fortuita por el lugar. En cuanto a los orígenes del desafortunado término, Rubio afirma que se comienza a utilizar a finales de Marzo de 1998, a raíz de dos retenes con secuestros masivos realizados en un mismo fin de semana por las FARC y el ELN en la vía al Llano y la Troncal del Oriente, que comunica el interior del país con la Costa Atlántica. (Citado de Centro Nacional de Memoria Histórica, 2013, p. 55)

Señala la verdad abierta que el testimonio de alias 'el Gato', guerrillero de las FARC capturado en 2003 y postulado a la ley de Justicia y Paz, reveló que para financiar el Comando Conjunto de Cundinamarca 'Marco Aurelio Buendía' el secretariado de las FARC autorizó aumentar el número de secuestros, extorsiones, boleteos y ‘pescas milagrosas' en el departamento. Esto coincide con estadísticas de la Fundación País Libre, que registró que sólo en 2003 al frente 22 de las Farc se le atribuyeron 21 secuestros en Cundinamarca y al menos un centenar de casos de extorsiones permanentes. (Verdad Abierta, 2013) 
Análisis Socio Jurídico del delito de secuestro en Colombia a partir de 1970

En ese mismo sentido, las cifras suministradas por el Centro Nacional de Memoria Histórica permiten aseverar que entre 1998 y 2002, ocurrieron 3542 hechos de "pescas milagrosas", 859 en los departamentos de Meta y Cundinamarca, 1186 fueron cometidas por las FARC y en cuanto a los años podemos advertir que el año con menor número de eventos fue 1999 con 351 y el mayor número sucedió en 2001 con 1046.

Gráfica 9. Retenciones ilegales o “pescas milagrosas” 1998-2002

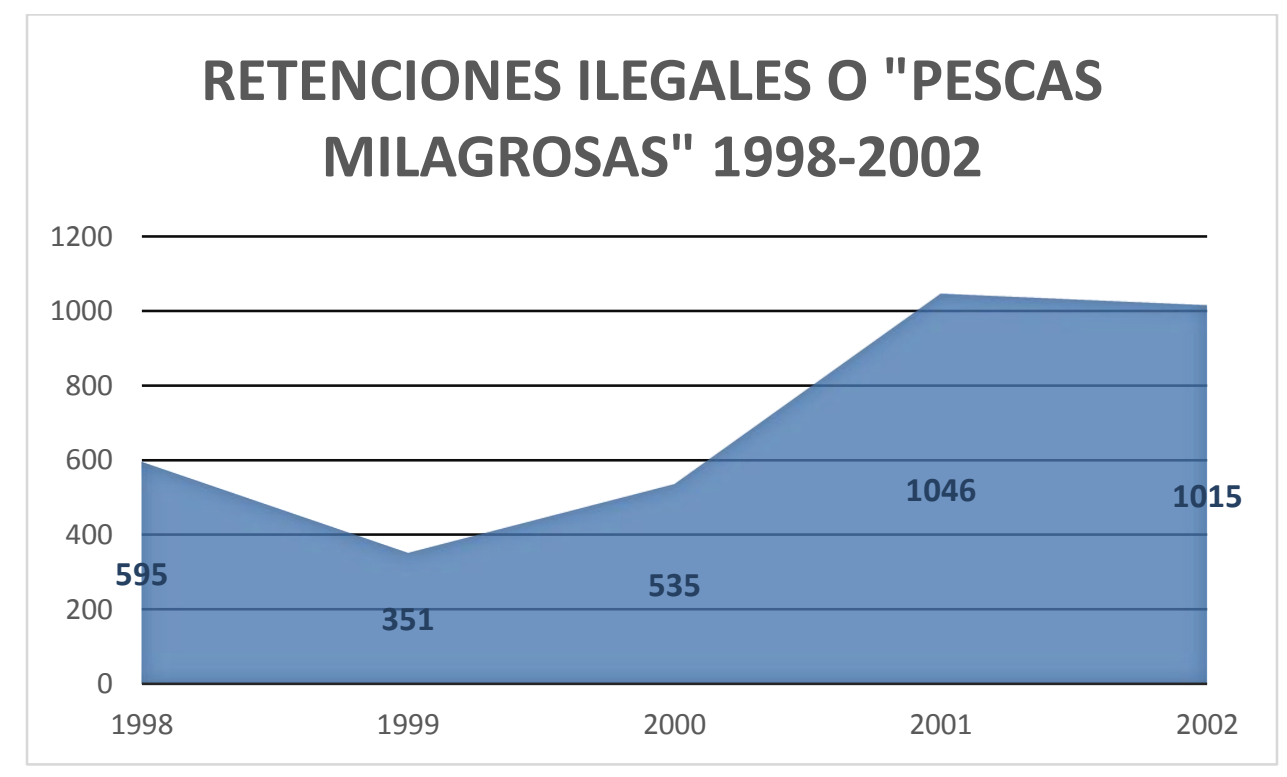

Fuente: Datos tomados del Centro Nacional de Memoria Histórica, 2013 (Elaboración Propia, 2018)

Una de las regiones más afectadas por estas retenciones ilegales de este tipo junto con los departamentos de Antioquia y Cesar, fue la comprendida entre los departamentos de Cundinamarca y Meta, ello se puede verificar en estudio realizado por el portal Verdad abierta, en el que se destaca la importancia de este territorio para las FARC dada su cercanía a la ciudad de Bogotá D.C. Se destaca que en 1998 este grupo subversivo fijó como uno de sus objetivos principales era controlar la Cordillera Oriental, y así acercarse a la capital, por tal razón se 
Análisis Socio Jurídico del delito de secuestro en Colombia a partir de 1970

conformó el Comando Conjunto Occidental de las Farc, comandado por el guerrillero Carlos Osorio Velásquez, alias 'Marco Aurelio Buendía' y optaron por enviar pequeños grupos de cinco o seis guerrilleros, para no ser detectados los milicianos llegaban vestidos de civil y conseguían un trabajo en la región. Una vez conocían el terreno y convencían a algunos jóvenes campesinos de hacer parte de la guerrilla, daban la orden para que llegaran el resto de los miembros del frente y asaltaban las estaciones de policía.

En 2000 las Farc tenían en Cundinamarca cerca de mil guerrilleros: el Frente 42 estaba desde San Juan de Río Seco, Girardot y La Mesa hasta Facatativá, Madrid y Mosquera. Los frentes 25, 52 y 55 se encontraban en Sumapaz; 53 y 54 delinquían en el suroriente del departamento; y en el norte se encontraban las compañías móviles Policarpa Salavarrieta, Vladimir Stivel y Manuel Beltrán, además el Frente 22 era de vital importancia para la estructura central de las Farc, porque fue el que más dinero aportó a esta guerrilla. Según han revelado guerrilleros desmovilizados, al mes entregaba cerca de 500 millones de pesos, que obtenían producto del secuestro extorsivo, el robo de ganado y dinero.

El guerrillero de las FARC Henry Castellanos, alias Romaña, quien ha sido criticado por ser uno de los inventores de este método para realizar estas retenciones fundamentalmente en la vía Bogotá Villavicencio, en entrevista rendida, justifica los secuestros denominándolos "RETENCIONES ECONOMICAS" los cuales buscaban la financiación del grupo por lo que ellos denominaban impuesto para la paz, establecido en su "ley 001 de reforma agraria revolucionaria" y "ley 002 impuesto para la paz". Agrega que las retenciones económicas era la única forma de sostener el movimiento guerrillero y estaban conscientes de las consecuencias negativas que les 
Análisis Socio Jurídico del delito de secuestro en Colombia a partir de 1970

podían traer, razón que en últimas los llevó a dejar de practicar este método abominable. (La Otra Cara, 2017)

Gráfica 10. Retenciones ilegales o "pescas milagrosas" 1998-2002 - Departamentos

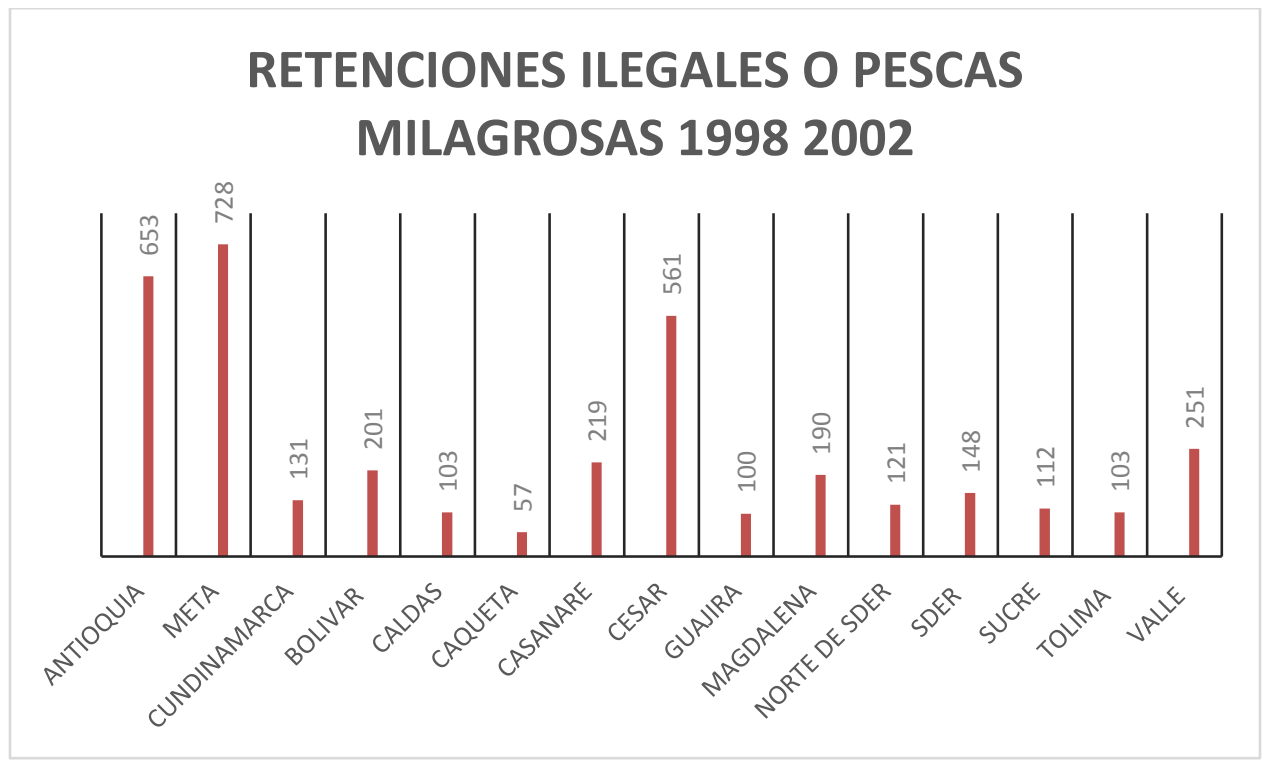

Fuente: Datos tomados del Centro Nacional de Memoria Histórica, 2013 (Elaboración Propia, 2018)

Como se dijo, el departamento de Antioquia ha sido a todo nivel quien ha ofrendado la mayor cantidad de víctimas de este flagelo, las cifras del departamento nacional de planeación permiten colegir que de los 13.616 secuestros extorsivos realizados entre 1996 y el 2003, el 19,4\% ocurrieron en ese departamento (2.648 personas secuestradas durante todo el período de estudio). El estudio explica esta situación al estar íntimamente relacionada con la intensidad del conflicto armado, por cuanto en Antioquia se registra la mayor cantidad de acciones armadas que desarrollan los grupos armados ilegales en el país (17\% del total de estas acciones). Además, este ha sido el territorio donde confluyen conflictos asociados con el narcotráfico, la guerra de guerrillas, el control y expansión de zonas mineras y agrícolas, entre otros. El departamento de Cesar arroja 
Análisis Socio Jurídico del delito de secuestro en Colombia a partir de 1970

también cifras destacadas en lo relacionado con la ocurrencia de este fenómeno en el periodo 19982002 con 561 casos, 429 de ellos cometidos por el ejército de liberación nacional y de estos 235 con motivación económica. (Departamento Nacional de Planeación, 2003) 


\section{Capítulo VII. Análisis Cualitativo de la Información Empírica Existente Sobre Secuestro en Colombia}

Una vez detalladas las diferentes modificaciones que se han realizado a la legislación penal colombiana en materia de secuestro, a continuación se procura efectuar un análisis de la información empírica existente sobre la ocurrencia de este fenómeno en nuestro país, a efecto de contrastar estas dos realidades y determinar cuál ha sido el grado de influencia de la primera sobre la segunda. Para tal efecto, se utilizara como insumo la realidad estadística aportada recientemente por el centro nacional de memoria histórica, así como por bases de datos de entidades públicas (DANE) y privadas que han realizado estudios sobre la materia. En el mismo sentido se utilizará información aportada por los entes estatales que se han encargado de la lucha en contra de este flagelo como lo es el GAULA, ejército Nacional, policía Nacional entre otras. Todo ello con mira de plasmar un estudio objetivo acerca de los efectos reales que puedan ser demostrados, ocurridos con posterioridad a la expedición de leyes encaminadas a prevenir o erradicar el secuestro en Colombia.

Es así como, del análisis de esta información podemos iniciar evidenciando que entre el año 2000 y el mes de enero del año 2017 el flagelo del secuestro se había reducido en un 94\%, ya que de 3.572 casos reportados en el año 2000, se disminuyó a 199 en 2016 y 190 en 2017. De acuerdo con cifras oficiales dadas por el comandante del Gaula tanto de la policía Nacional como del Ejército de Colombia, con la entrada en vigencia de los acuerdos de paz con las Farc así como el inicio de las negociaciones con el ELN, el año 2015 culmino con 141 casos y el 2016 finalizó con un número de 205 raptos, en total contraste con lo sucedido en el año 2000, cuando como se dijo se cometieron más de 3.500 secuestros, siendo esta la cifra más alta de la historia de Colombia. 


\section{Análisis Socio Jurídico del delito de secuestro en Colombia a partir de 1970}

El oficial indicó que la delincuencia organizada ha sido la encargada de realizar los recientes secuestros extorsivos presentados en regiones como Antioquia, Arauca y Cauca, por lo que se han reducido considerablemente los casos que involucran a las guerrillas. En 2016, más de la mitad de los 205 raptos fueron secuestros simples, es decir que los extorsivos se redujeron. Igualmente, no hubo reportes de secuestros políticos. (Asuntos Legales, 2017)

Gráfica 11. Evolución delito del secuestro año 1996 al 2015

\section{EVOLUCIÓN DEUTO DE SECUESTRO AÑO 1996 AL AÑO 2015}

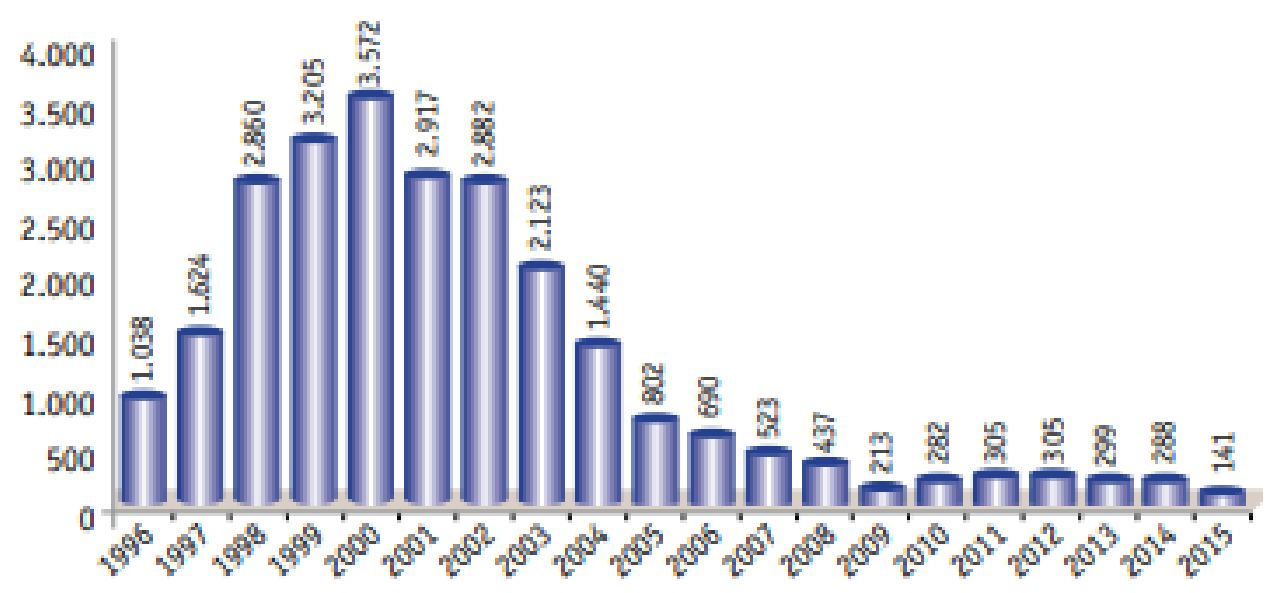

Fuente: Ministerio de Defensa, 2015

Como se ha venido reseñando en este estudio, los datos compilados por el Centro Nacional de Memoria Histórica y la empresa especializada Cifras \& Conceptos, dejan ver toda una historia de dolor que ha sufrido Colombia en materia de secuestro durante más de 40 años. Se recuerda que en el país han sido secuestradas 39.058 personas, al menos una vez, entre 1970 y el 2010, el período que cubre el estudio dentro de los cuales se plagiaron más de 3.000 menores se cuentan y 1.100 secuestrados han sido extranjeros. 
Análisis Socio Jurídico del delito de secuestro en Colombia a partir de 1970

Dada esta importante mengua en el porcentaje de casos de secuestro cometidos en nuestro país, se cree ineludible analizar cuál fue la eficacia de la legislación expedida sobre la materia, para cuyo estudio, se considerarán tres de las más relevantes leyes expedidas, recordando los principales motivos o argumentos tenidos en cuenta por el legislador para su expedición, contrastando con la información empírica existente sobre el fenómeno de secuestro en Colombia, con el fin de concluir si se han cumplido los objetivos planteados por el congreso al momento de expedirlas. De otra parte, se considera necesario establecer que otras circunstancias contextuales ó históricas pueden tener una relación directa con esta disminución.

\subsection{Ley 40 de 1993}

Abordando el tema de la legislación expedida y su análisis, iniciaremos por la ley 40 de 1993 cuyo origen está en la fundación PAIS LIBRE creada por Francisco Santos en ese mismo año ocho meses después de su liberación; a través de ella se desarrolló este proyecto de iniciativa popular para combatir el secuestro, que más tarde se convirtió en la precitada disposición llamada también Estatuto Nacional contra el Secuestro, que no conto con apoyo gubernamental, sino que obedeció a que País Libre recolectó en poco tiempo el millón de firmas necesario para llevar ante el Parlamento un conjunto de medidas que atacaban el crimen repugnante del secuestro no en sus consecuencias sino a su raíz. En el Congreso, el proyecto contó con la ponencia del senador Luis Guillermo Giraldo, y la esencia de la iniciativa popular era prohibir con medidas muy drásticas pero prácticas el pago de rescates, mediante el procedimiento de autorizar al Estado para intervenir transitoriamente los bienes de las víctimas y de sus familias inmediatas y congelarlos, con el fin de evitar que con ellos se atendiera las exigencias del grupo secuestrador. 
Análisis Socio Jurídico del delito de secuestro en Colombia a partir de 1970

Las estadísticas de la época revelaban que en el período comprendido entre 1964 y 1991 se cometieron en el país 7.453 secuestros, y solamente en el año 1991 se cometieron 1408. Resalta que en promedio sólo el 12\% de los casos culminan en el rescate de la víctima, el $10 \%$ de los secuestrados son asesinados y el $45 \%$ liberados tras el pago de una suma millonaria, que el pago promedio por secuestro es de 50 millones de pesos. Destaca que entre 1987 y 1991 se pagaron 175.000 millones de pesos en rescates a los secuestradores y que apenas el 20\% de los casos de secuestro son denunciados a las autoridades lo cual suponía que todas estas estadísticas subestiman la magnitud verdadera del fenómeno.

Por esa razón el Congreso decidió realizar una profunda modificación al régimen que reglamentaba el delito del secuestro, ya que las disposiciones vigentes se consideraron insuficientes tanto por su contenido como por sus alcances para erradicar en forma definitiva uno de los crímenes más abominables de la humanidad. En ese mismo camino se incrementaron las penas existentes para el delito de secuestro, lo cual fue en ese entonces avalado por la Corte Constitucional que considero este aumento como necesario si tiene en cuenta el fenómeno creciente de la criminalidad y delincuencia en nuestro país en los últimos años, ante lo cual se hacía imperioso evaluar las posibilidades y la verdadera eficacia de la justicia penal y de las sanciones por ella previstas, para efectos de garantizar la protección de los bienes jurídicos más fundamentales para el ser humano.

Para la época, basados en los informes de inteligencia de 1993, se podría concluir que el número de secuestros comenzó a descender desde octubre de 1992, fecha que coincidió con la iniciativa popular que dio origen al estatuto contra el secuestro. En efecto, las declaraciones dadas por el director de la Dijin, general Luis Enrique Montenegro, permitieron identificar como causas para la disminución del delito la colaboración ciudadana, las denuncias, las medidas preventivas, 
Análisis Socio Jurídico del delito de secuestro en Colombia a partir de 1970

la aplicación de la ley y la toma de conciencia frente a este flagelo, ello aunado a la especialización que habían alcanzado los integrantes de las Únase, para luchar contra las bandas dedicadas a cometer este delito. Consecuencia de lo anterior para 1993, según el oficial los delincuentes habían debilitado su estructura criminal y ahora, por ejemplo, está invirtiendo menos en la comisión de un ilícito, ante las posibilidades de fracaso. (El Tiempo, 1993)

En la exposición de motivos de la ley 40 de 1993, se arguyó la necesidad de la expedición de una ley que endureciera la actitud contra el secuestro, y que estaría llamada a producir importantes efectos disuasivos a través de la imposición de sanciones elevadas en cuanto al número de años de prisión, para delitos de semejante gravedad y atrocidad como el secuestro, ya que una de las formas, quizá la más idónea para asegurar los fines del Estado, sea la de garantizar la convivencia pacífica, que se logra a través de la prevención y represión de las conductas delictivas mediante la imposición de penas y sanciones que sean verdaderamente proporcionales a la gravedad del hecho punible y a la mayor o menor afectación de los derechos fundamentales de las personas.

No obstante, el estudio de las cifras publicadas por el CNMH permite evidenciar que para el año 1991 se habían presentado 766 secuestros, suma que asciende en 1992 a 912; al ser expedida la ley 40 en enero 19 de 1993 el fenómeno desciende a 354 casos, pero vuelve a elevarse en 1994 con 691 casos y en 1995 con 509 casos. En otras palabras, la expedición de esta norma no logró con su finalidad de neutralizar, debilitar y malograr la estructura logística y la capacidad operativa de la delincuencia organizada que ha hecho del secuestro una macabra industria ilícita, así como fortalecer los sistemas de protección y de garantía a los valores, principios fundacionales y derechos más caros al Estado social de derecho, por el contrario, se presentó un incremento en los casos en las fechas posteriores a su expedición, por ende este "efecto disuasivo" no llego a 
concretarse y por el contrario, si en 1993 la guerrilla de las FARC en 1993 cometió 62 secuestros, entrada en vigor la ley, esta cifra asciende a 116 en 2004 y 85 en 2005. De la misma forma en lo que refiere a delincuencia común se reportaron 56 casos en 1993, 125 casos en 1994 y 85 en 2005 lo que indica que luego de 1993 lejos de disminuir, este número fue en ascenso.

Gráfica 12. Casos secuestro 1992-1995

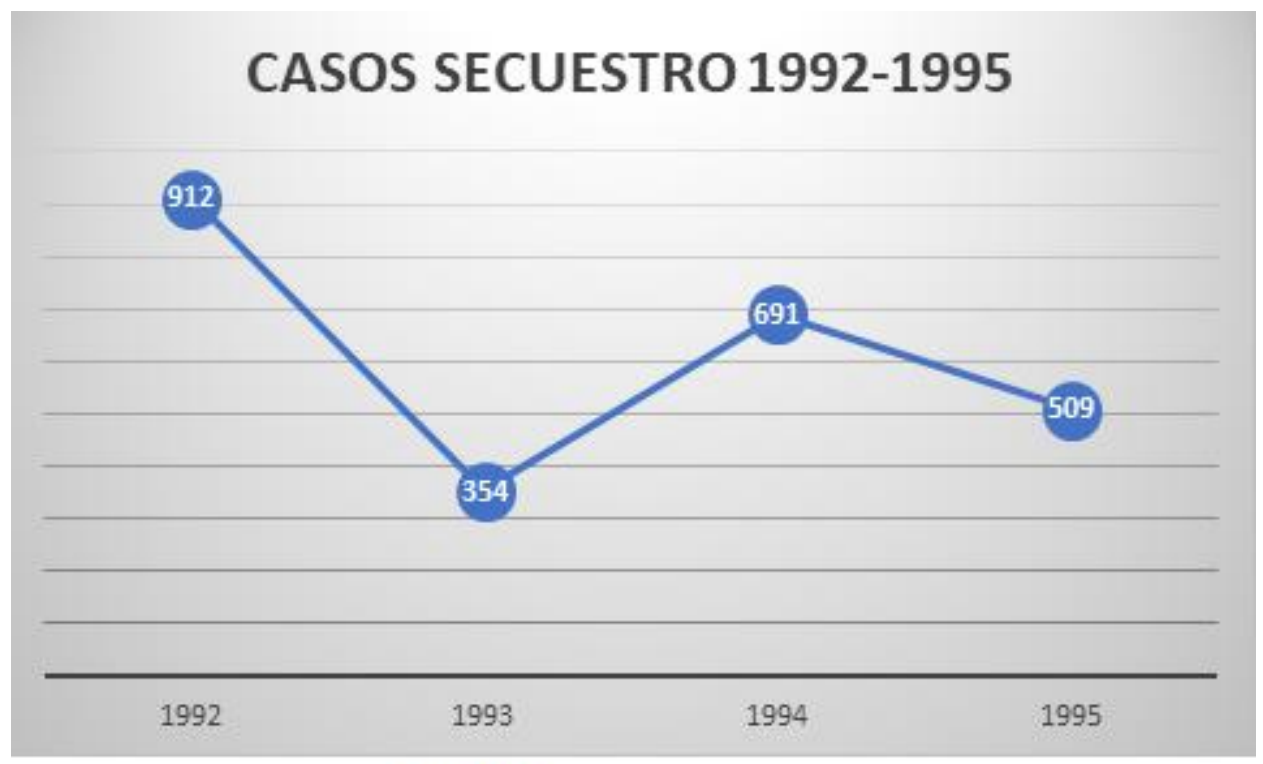

LEY 40

Fuente: Datos Tomados del Centro Nacional de Memoria Histórica, 2013. (Elaboración propia, 2018) 
Gráfica 13. Efectos de la ley 40 de 1993 sobre secuestro

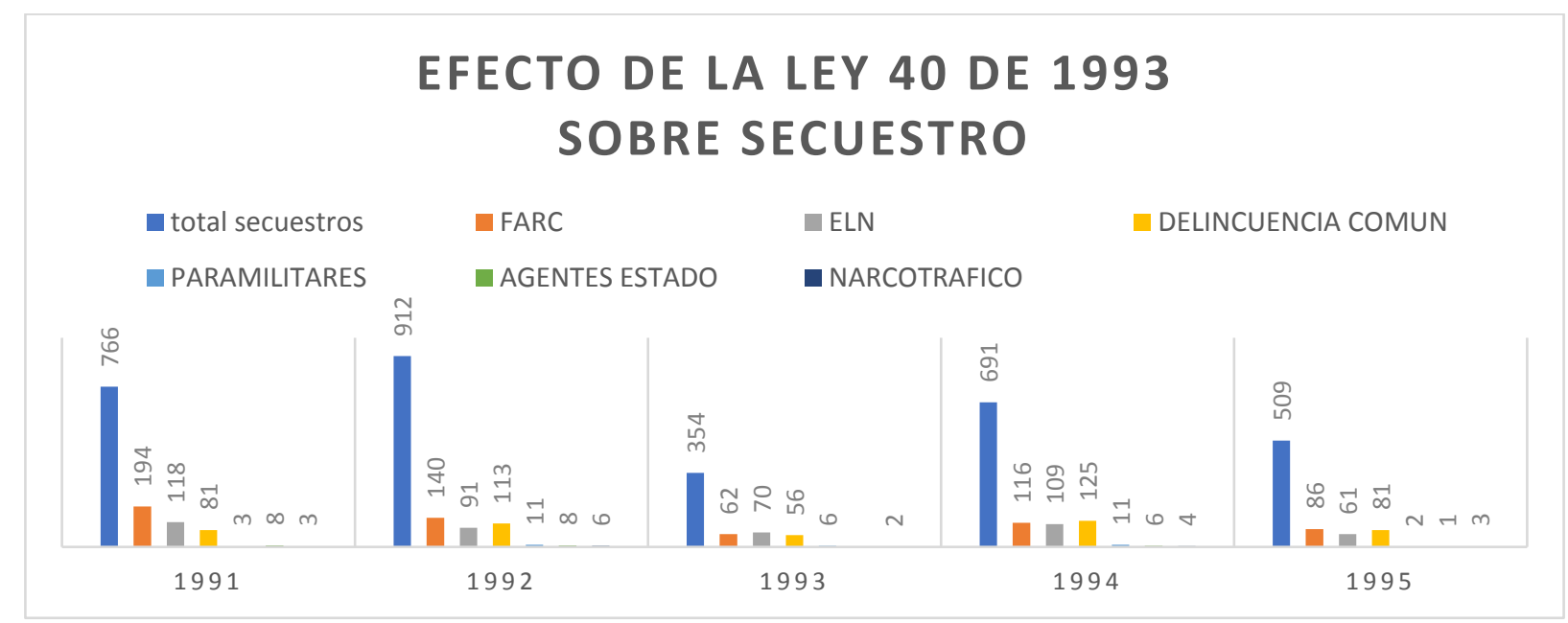

Fuente: Datos Tomados del Centro Nacional de Memoria Histórica, 2013. (Elaboración propia, 2018)

Gráfica 14. Efecto de la ley 40 de 1993 sobre secuestro

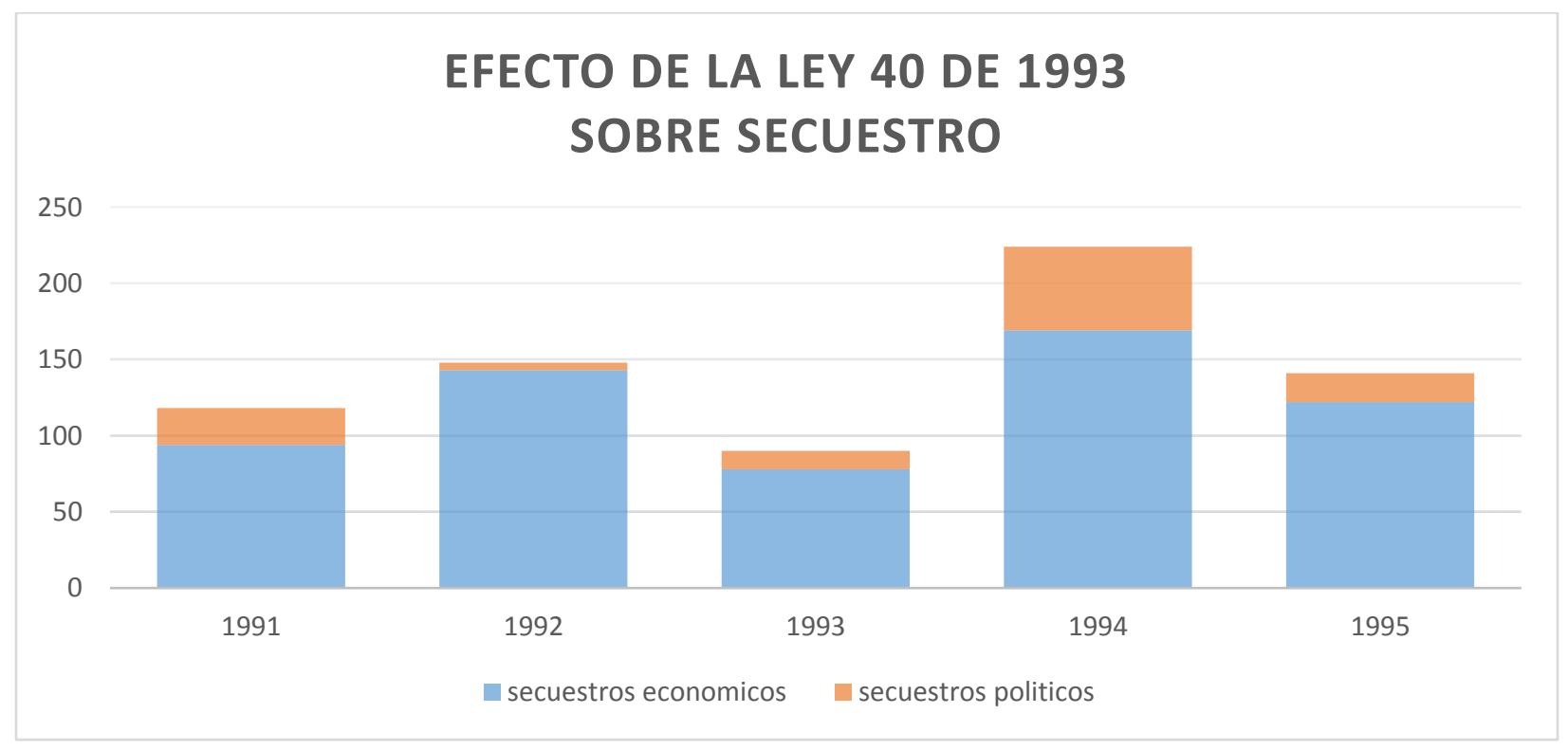

Fuente: Datos Tomados del Centro Nacional de Memoria Histórica, 2013. (Elaboración propia, 2018) 
Análisis Socio Jurídico del delito de secuestro en Colombia a partir de 1970

A continuación analizaremos en conjunto el efecto de las leyes 599 de 2000 (Código

Penal) y su posterior reforma la ley 733 de 2002.

\subsection{Ley 599 de 2000 código penal actual}

Como se advirtió en precedencia, con la implementación de la Ley 599 de 2000 se forjaron cambios relevantes en la legislación penal, ya que se buscaba darle un nuevo aire, sintonizándola con una nueva razón adaptada a los principios y valores consagrados en la Constitución de 1991, incorporando para ello una serie de garantías penales materiales convertidas en sus normas rectoras. Las penas señaladas para el secuestro simple son de prisión de diez a veinte años y multa de seiscientos a mil salarios mínimos legales mensuales vigentes y para el extorsivo de prisión de dieciocho a veintiocho años y multa de dos mil a cuatro mil salarios mínimos legales mensuales vigentes. Respecto de las causales de agravación para el secuestro extorsivo que trata el artículo 170 de la ley 599 de 2000, las aumenta en una tercera parte.

Si tenemos en cuenta el antecedente legislativo en materia de secuestro (ley 40 de 1993) tenemos que en lo que respecta al secuestro extorsivo, pasan las penas a imponer de veinticinco a cuarenta años de prisión a dieciocho a veintiocho años de prisión. De otra parte, establece un periodo de favorabilidad que se extiende hasta 1988, donde la pena máxima es 13 años mayor que la impuesta en el año 1980. Así mismo, dentro del aumento de penas está contemplada la incorporación de agravantes y atenuantes del delito. Los agravantes han sido diseñados en función de la protección de las víctimas, el castigo de los métodos empleados durante el secuestro y las finalidades del secuestrador. 


\subsection{Ley 733 de 2002}

Para contextualizar, debemos recordar que la zona de distensión del Caguán (1998-2002) coincide claramente con el periodo de Masificación (1996-2000) del secuestro. Es en esta época en la que las FARC se destacan como el principal autor de secuestros en el país, ya que de la totalidad de los secuestros perpetrados entre 1999 y 2004 (17.828 casos) 8.385 casos tuvieron motivación económica y 1.040 casos con exaltación de orden político. De estos 17.828, 5.267 fueron cometidos por las FARC, 4351 por el ELN y 3899 por delincuencia común, siguiendo con la tendencia de las FARC como el más grande secuestrador de todos los tiempos en nuestro país. (Ariza, 2014)

En 2002 llegó al poder Álvaro Uribe Vélez quien inició la implementación del Plan patriota, intensificando el combate contra las FARC, sosteniendo la tesis de que en Colombia no existe un conflicto armado sino una amenaza terrorista. Durante los dos gobiernos del presidente Uribe (2002 - 2010) no existió ningún acercamiento ni intento de paz con esta guerrilla, además que no fue posible concretar un acuerdo humanitario para la búsqueda de la liberación de los secuestrados políticos y de la fuerza pública en manos de las FARC.

El legislador consideró para el 2002 que la "rebaja" de penas realizada con la expedición de la ley 599 de 2000 no era acorde con la situación que se padecía en ese momento, por lo que se sanciona la ley 733 cuyo objetivo principal era el de erradicar los delitos de secuestro, terrorismo y extorsión, por cuanto, para la época el secuestro al igual que el terrorismo y la extorsión eran considerados como delitos atroces y abominables causantes de una gran alarma social que estaban afectando en forma grave y ostensible, valores y derechos inalienables del ser humano como la vida, la dignidad, la libertad personal, la intimidad, el libre desarrollo de la personalidad, la libre 
circulación, el trabajo, la familia, la libre participación ciudadana y la paz, todos amparados por la Constitución Política y las leyes.

Del análisis de las cifras suministradas por el Centro Nacional de Memoria Histórica, podemos recalcar que para el año 1999 se perpetraron en nuestro país 3.354 secuestros, en el año 2000 se cometieron 3.547, en el año 2001 se realizaron 3.545 y en el 2002 ocurrieron 3.306, con posterioridad a la expedición de esta ley 733, en el año 2003 se ejecutaron 2303 y en 2004 acaecieron 1.773 secuestros.

Gráfica 15. Casos secuestro 1998-2005

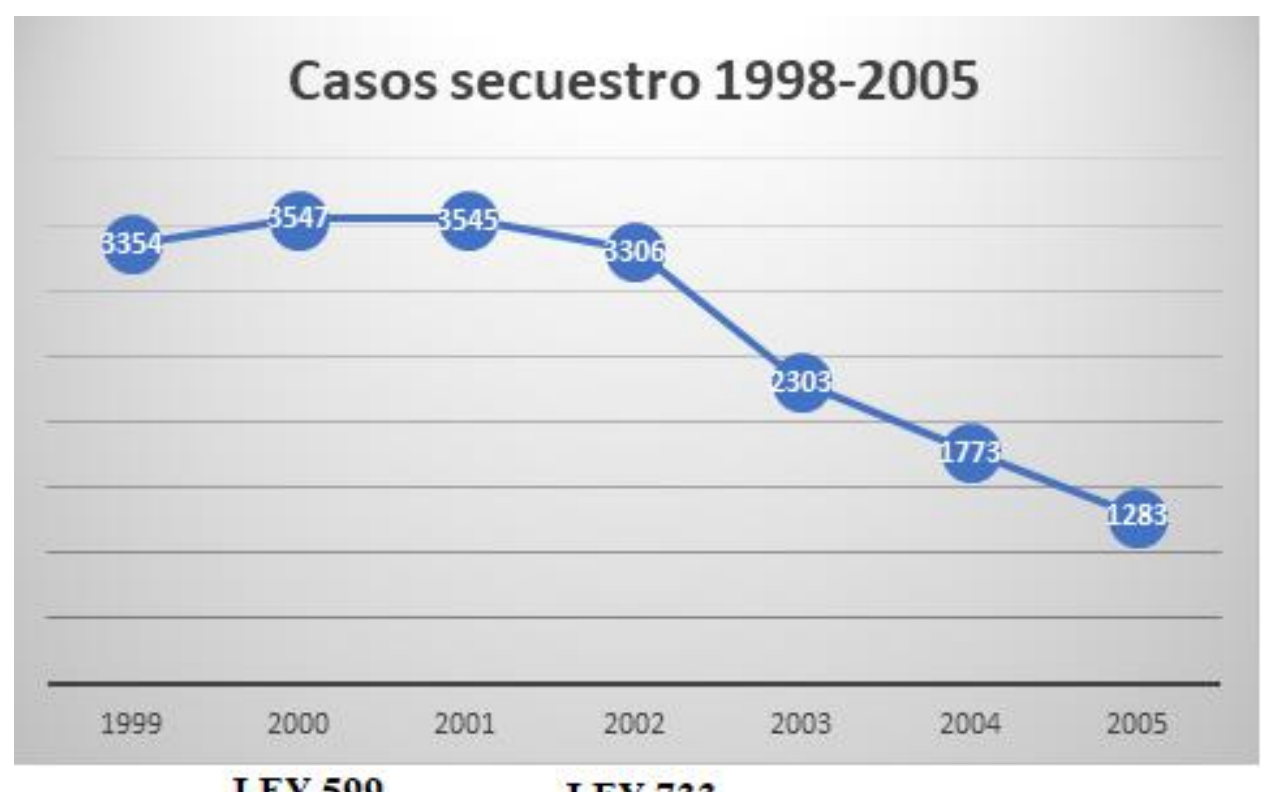

LEY 599

LEY 733

Fuente: Datos Tomados del Centro Nacional de Memoria Histórica, 2013. (Elaboración propia, 2018)

Podríamos entonces aseverar que la expedición de esta legislación cumplió con uno de sus objetivos, consistente en disminuir la ocurrencia de casos de este delito. No obstante, debemos analizar el hecho que las agrupaciones guerrilleras que venían siendo considerados como los "más 
grandes secuestradores "decidieron mutar su forma de financiación, dejando de lado el delito de secuestro para utilizar la extorsión para este propósito. Por ejemplo, el grupo subversivo FARC cometieron en el año 2000 la cifra de 916 secuestros, en el año 2001 ejecutaron 1.026, en el año 2002 cometieron 1.120, y posterior la ley en el año 2013 ejecutaron 771 y en el año 2004 intervinieron en 414 secuestros. Lo anterior permite advertir que, si bien la legislación influyo en el descenso de ocurrencia de estos casos, es solo uno de los factores que se deben analizar, por cuanto los guarismos dejan ver la influencia de otros acontecimientos en la mengua del delito. Lo anterior se ratifica con el incremento de los secuestros cometidos por la delincuencia común que paso de 526 casos en 1999 a 735 en 2002 y 747 en 2004.

Gráfica 16. Efectos leyes 599 de 2000 y 733 en temas de secuestro

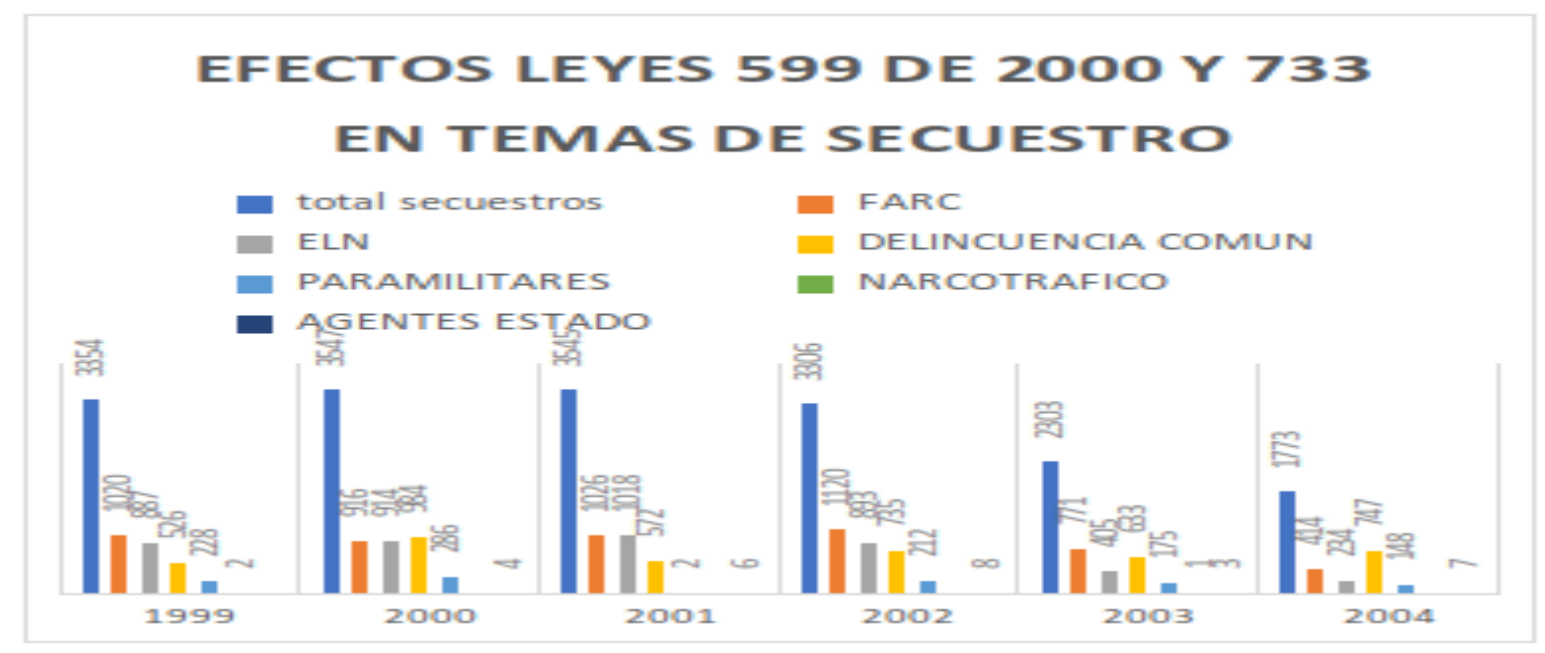

Fuente: Datos Tomados del Centro Nacional de Memoria Histórica, 2013. (Elaboración propia, 2018) 
Gráfica 17. Evolución delito del secuestro año 1996 al 2015

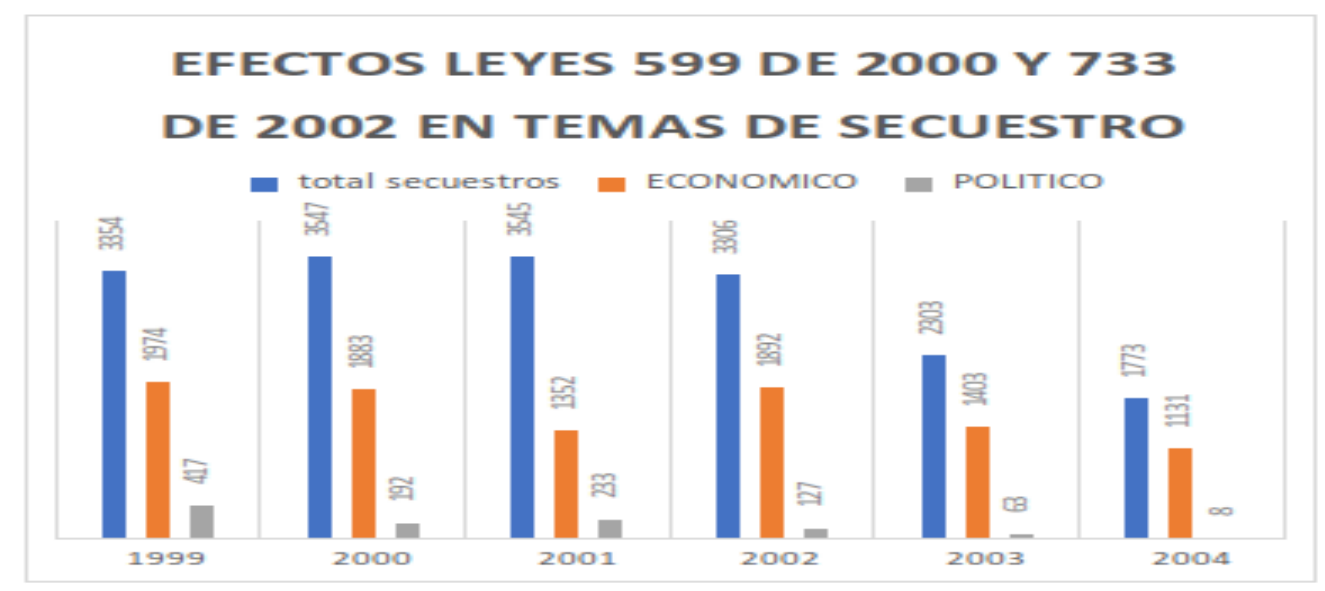

Fuente: Datos Tomados del Centro Nacional de Memoria Histórica, 2013. (Elaboración propia, 2018)

\subsection{Ley 1121 de 2006}

En el lapso en que se produjo este precepto, nuestro país aún se encontraba en el estado de "conmoción interior" promulgado con base en la situación de inseguridad generada por las bandas armadas organizadas, que amenazaban a mandatarios locales, regionales y nacionales y por lo tanto al funcionamiento de las instituciones democráticas, así como por la insuficiencia de los recursos económicos y militares a disposición del Estado para contrarrestar la violencia, entre otros. En ese escenario, el 29 de diciembre de 2006 el congreso de la república expide la ley 1121 por la cual se dictan normas para la prevención, detección, investigación y sanción de la financiación del terrorismo y otras disposiciones, disponiendo específicamente en su artículo 26 la exclusión de subrogados, rebajas de pena y beneficios cuando se trataba de 
investigaciones relacionadas con delitos de terrorismo, financiación de terrorismo, secuestro extorsivo, extorsión y conexos, no procederán las rebajas de pena por sentencia anticipada y confesión. (Corte Constitucional, Sentencia C-073/10).

Gráfica 18. Casos secuestro 2001-2008

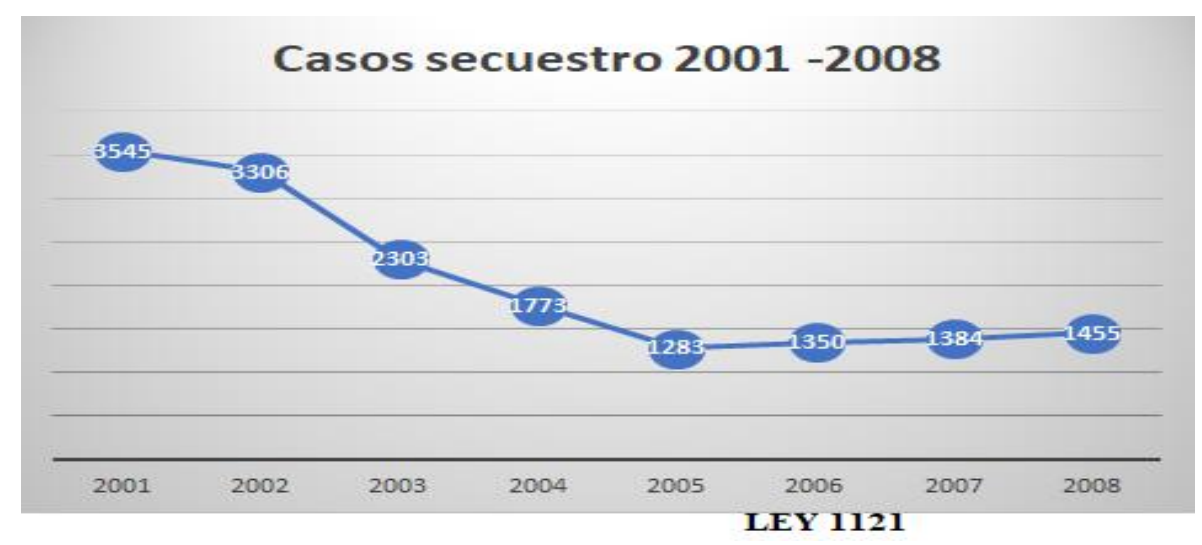

Fuente: Datos Tomados del Centro Nacional de Memoria Histórica, 2013. (Elaboración propia, 2018)

Gráfica 19. Efectos expedición ley 1121 de 2006

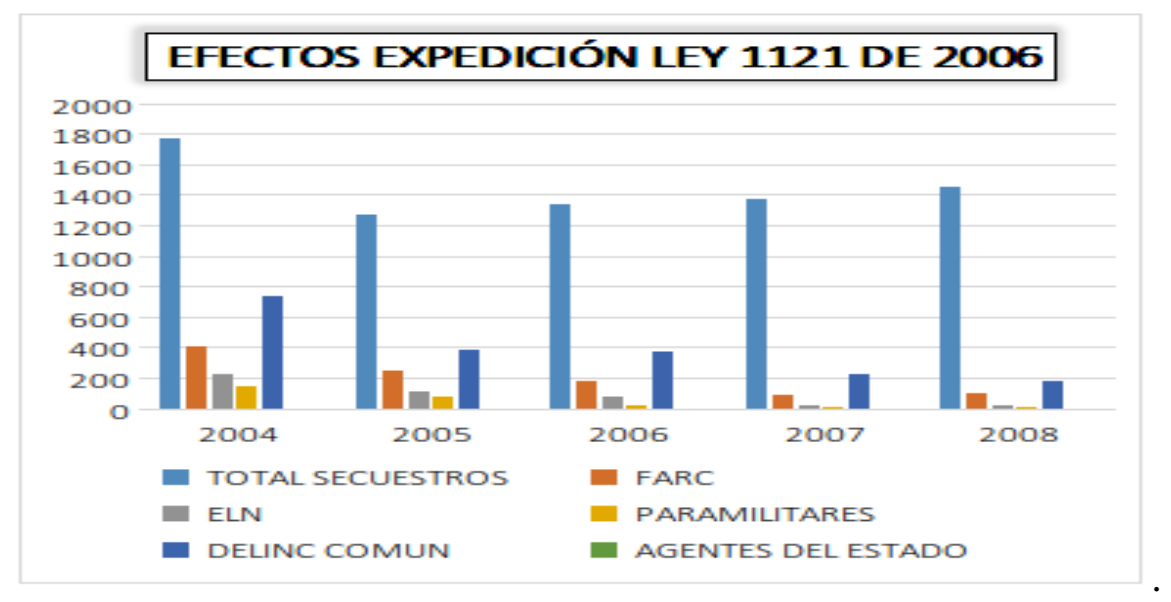

Fuente: Datos Tomados del Centro Nacional de Memoria Histórica, 2013. (Elaboración propia, 2018) 
Gráfica 20. Efectos expedición ley 1121 de 2006

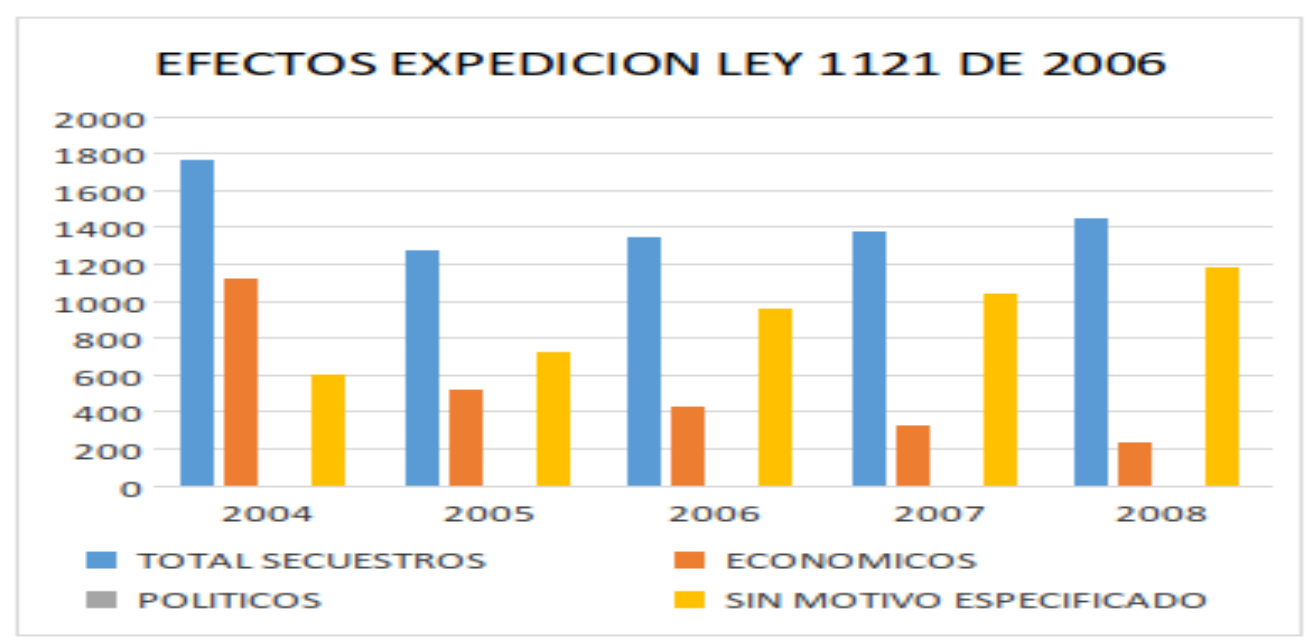

Fuente: Datos Tomados del Centro Nacional de Memoria Histórica, 2013. (Elaboración propia, 2018)

Siguiendo la misma línea del análisis del efecto de las anteriores normas, de las cifras se evidencia que en el año 2004 ocurrieron 1.773 secuestros, en 2005 sucedieron 1.283, en 2006 ocurrieron 1.350 y con posterioridad a esta ley 1121, en 2007 se cometieron 1.384 y en 2008 una cifra de 1.455 secuestros. Con relación a la autoría de grupos guerrilleros en estos casos, específicamente las FARC se tiene que en 2004 cometieron 414 secuestros, en el 2005 realizaron 252, en el 2006 ejecutaron 184, en el 2007 intervinieron en 99 y en el 2008 participaron en 104. Por otra parte, los grupos de delincuencia común pasaron de cometer 747 casos en 2007 a ejecutar 182 en 2008.

A manera de conclusión, de este análisis de las cifras podemos evidenciar como denominador común que la legislación no cumplió con los objetivos trazados de erradicar, prevenir la comisión del secuestro en nuestro país, ya que si bien en algunos casos se disminuyó en otros se mantuvo igual o en el peor de los casos aumentó luego de la expedición de las normas. Sin 
Análisis Socio Jurídico del delito de secuestro en Colombia a partir de 1970

embargo, es incuestionable que en este momento existe afortunadamente una realidad cual es la disminución ostensible de la práctica de este delito, ante ello, cabe entonces preguntarse: ¿Si este descenso no fue efecto único de la legislación, existirán otras causas que pueden tener influencia en la disminución del ilícito de secuestro? En nuestro concepto si los hay y tienen que ver con la desmovilización de bandas criminales y grupos guerrilleros, y antes de ello la mutación de estos grupos hacia otras formas de financiación diferentes a la comisión del delito.

\subsection{Otras causas que influyeron en la disminución del delito de secuestro en Colombia}

\subsubsection{Desmovilización de grupos paramilitares o autodefensa}

Durante el mandato del entonces presidente Álvaro Uribe Vélez se efectúa la desmovilización y desarme de 34 bloques de las Autodefensas Unidas de Colombia entre los años 2003 y 2006, allí iniciaría el que se denominó proceso de Justicia y Paz con el que se buscaba la verdad, justicia y reparación de las víctimas de los paramilitares. Las desmovilizaciones de las autodefensas se iniciaron el 25 de noviembre de 2003 en Medellín con el bloque Cacique Nutibara y terminaron el 15 de agosto de 2006 con el bloque Elmer Cárdenas y en 38 actos se desmovilizaron 31.671 de los integrantes de los grupos irregulares, siendo las organizaciones con mayor número de desmovilizados el bloque Central Bolívar con 6.348, el bloque Norte con 4.760, el bloque Mineros con 2.780, el bloque Héroes de Granada con 2.033 y el bloque Elmer Cárdenas con 1.538. (Organización de Estados Americanos, 2007)

Sobre la cifra de secuestros cometidos por las agrupaciones paramilitares, aparecen reportados en las bases de datos de cifras y conceptos, 1.677 casos de secuestro, siendo los años de mayor ocurrencia, 2001 con 586 casos y 286 eventos delictivos. (Cifras y Conceptos, 2010) 
Análisis Socio Jurídico del delito de secuestro en Colombia a partir de 1970

Para el caso de los secuestros realizados por los grupos paramilitares y los Grupos armados posdesmovilización (GAPD), el momento de intensidad nacional más importante fue en 2001 con 807 víctimas. En gran medida, el secuestro se concentró en la etapa de mayor expansión (19982005). En la etapa de pos desmovilización el desescalamiento en esta modalidad de violencia fue muy intenso y generalizado a nivel nacional. Sin embargo, encontramos algunos casos atípicos que pueden estar relacionada con la nueva etapa de los GAPD que, desbordados en su violencia y fragmentados, decidieron incluir en sus medios de financiación el secuestro. Es así como según datos del centro nacional de memoria histórica, la tendencia de desescalamiento intenso para el periodo pos desmovilización, vio cómo se redujeron las estadísticas de casos de las masacres al igual que el secuestro y la desaparición forzada son modalidades cuya magnitud disminuyó en el periodo de estos grupos armados. (Centro Nacional de Memoria Historica, 2006-2015)

Gráfica 21. Distribución de la violencia no letal paramilitar y7o GAPD en Colombia. Discriminado por modalidades antes y después de la desmovilización de 2006

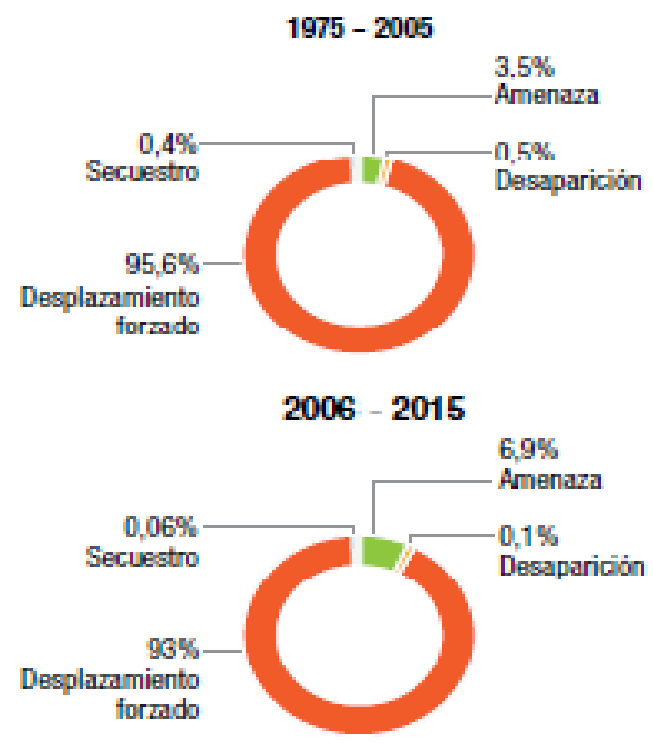

Fuente: Centro Nacional de Memoria Histórica, 2006-2015 


\subsection{2 ¿Las FARC Dejaron de Secuestrar?}

Por medio de datos estadísticos, el Centro Nacional de Memoria Histórica realizó un balance de los responsables del secuestro, desde 1970 hasta 2010 diseñando una base de datos compuesta por 98 variables, entre las que están los presuntos autores y los autores confirmados del secuestro en Colombia. Por el lado de los presuntos autores, en primer lugar, aparece la guerrilla de las Farc, responsable del 33\% de los secuestros, seguida por las redes criminales (27\%), el Eln (25\%), los grupos paramilitares $(7 \%)$ y otros no definidos que serían los presuntos responsables del 8\% del total de secuestros en el país en 40 años de historia.

Por lo anterior, las Fuerzas Armadas revolucionarias de Colombia, recibieron en nuestro país el deshonroso título de" el mayor secuestrador", a tal punto que hasta 1999 según datos de ese centro se habían reportado 4.309 casos en los cuales aparecen como presuntos autores de secuestros en los que 720 tienen motivación política y 1.714 motivación económica. (Centro Nacional de Memoria Histórica, 2013)

Gráfica 22. Secuestros FARC 1970 -1999

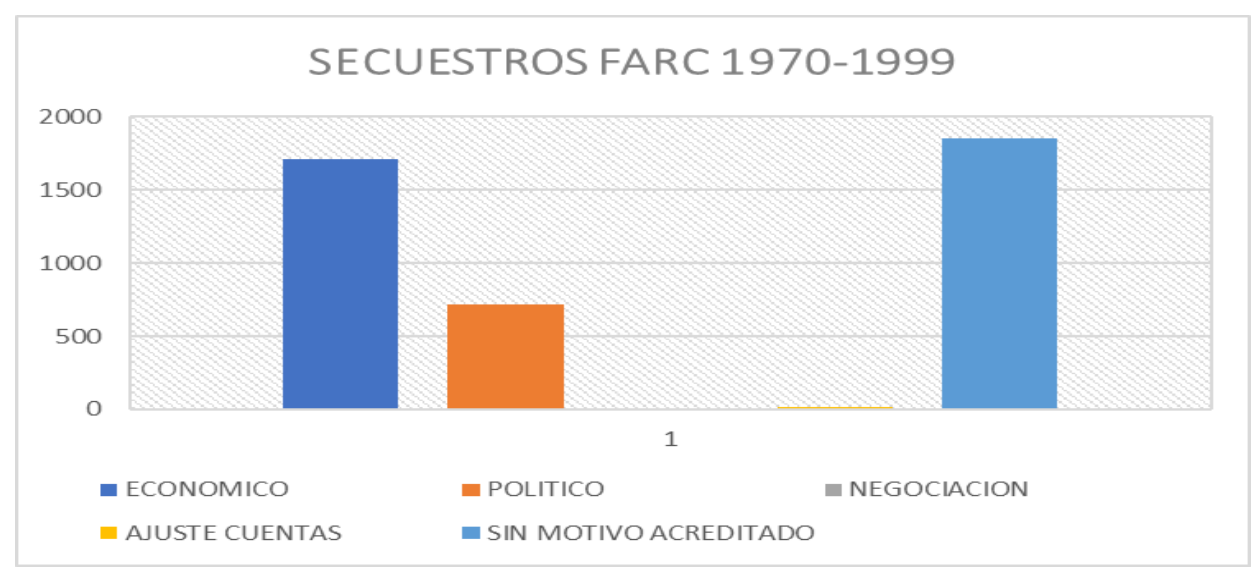

Fuente: Datos Tomados del Centro Nacional de Memoria Histórica, 2013. (Elaboración propia, 2018) 
Análisis Socio Jurídico del delito de secuestro en Colombia a partir de 1970

Posteriormente en el año 2000, las Farc comenzaron a secuestrar políticos ante la renuencia del Estado Colombiano a realizar "intercambio humanitario" entre los guerrilleros detenidos en las cárceles y los soldados y oficiales secuestrados. Para ese entonces se exigía por parte de la subversión el despeje de una zona San Vicente del Caguán y Cartagena del Chairá (Caquetá) a lo cual mediante comunicado público renunciaron y a la vez aceptaron que se realizara el intercambio en dos poblaciones vallecaucanas (Florida y Pradera) siempre que se reunieran las garantías de seguridad para el desplazamiento de sus voceros, el traslado de los secuestrados que serían liberados y el posterior repliegue de los más de 500 guerrilleros que deberían ser liberados. Ante ello, el presidente Uribe reiteró que había que buscar una solución diferente al despeje, pues ese tema había que descartarlo durante su administración. (El Tiempo, 2004)

Esto origina la reacción de la guerrilla que mediante un pronunciamiento del entonces jefe del grupo subversivo manifestó que el intercambio se realizaría sin duda alguna cuando los secuestrados fuesen miembros del "establecimiento político - "“¡allí donde les duela más!", tronaba Arnulfo Briceño, alias el Mono Jojoy, "Ahí si van a gritar!" (Centro Nacional de Memoria Histórica, 2013). Cumpliendo con esta amenaza las FARC perpetraron 53 casos de secuestros políticos solamente en el año 2000, a cuyas víctimas se les denominaba por parte de las FARC como "prisioneros de guerra" quienes eran mantenidos cautivos en las selvas colombianas en las más infames condiciones que alcancemos a suponer. 
Gráfica 23. Secuestros FARC años 2000 motivo argumentado

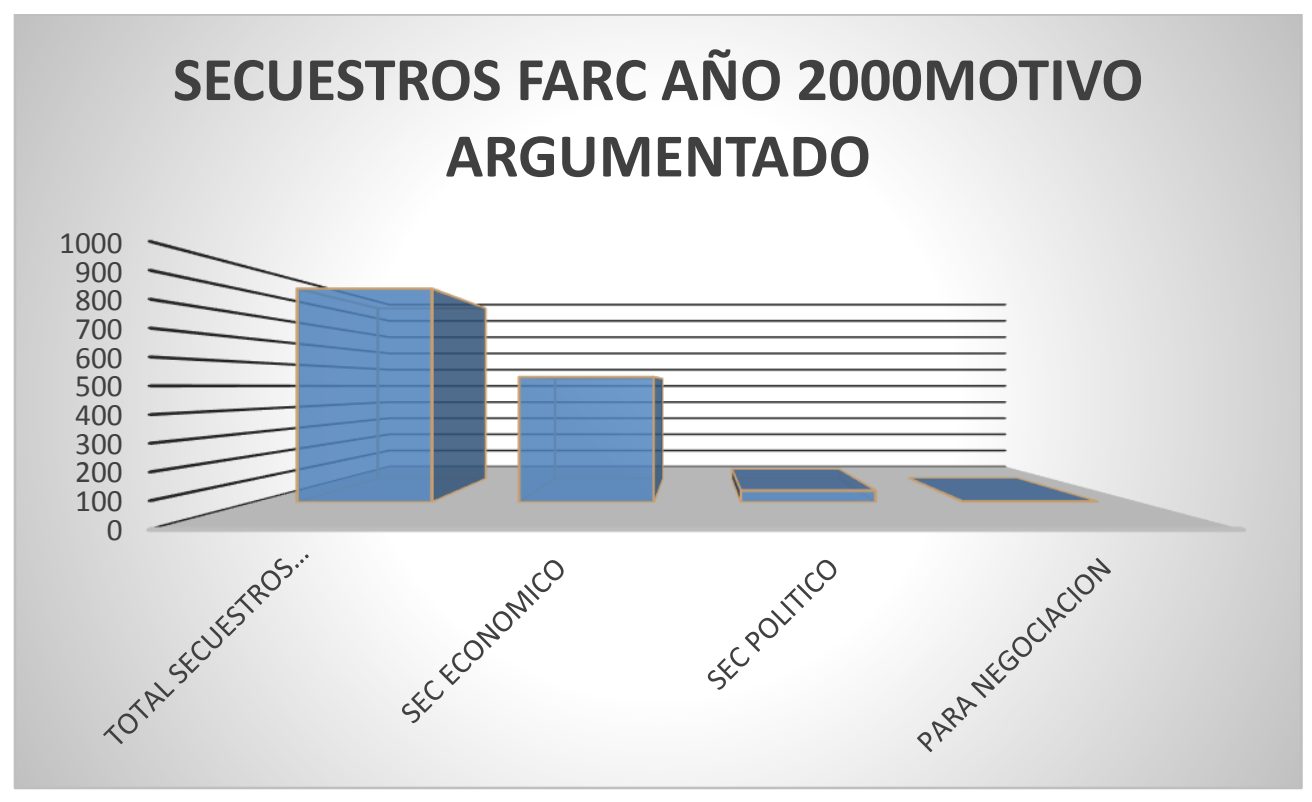

Fuente: Datos Tomados del Centro Nacional de Memoria Histórica, 2013. (Elaboración propia, 2018)

Figura 8. FARC campos de concentración

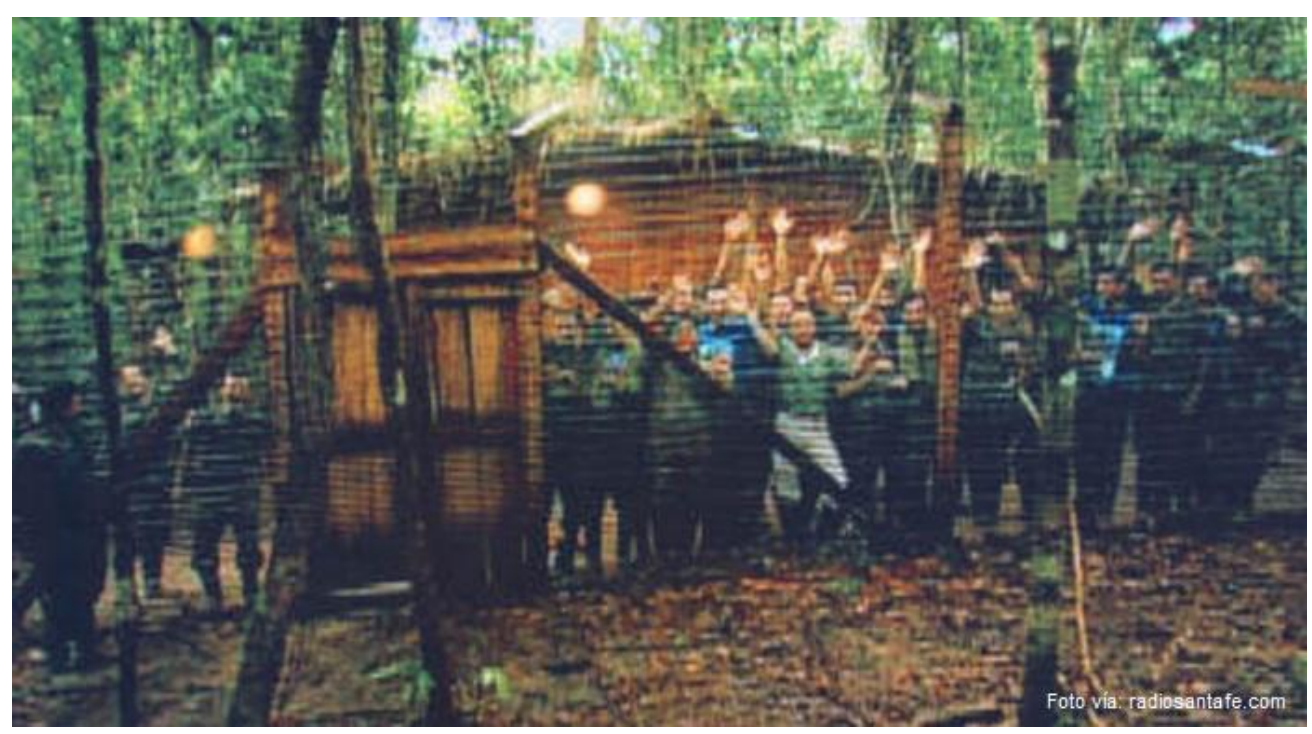

Fuente: Radio Santa Fé, 2016 
Figura 9. El secuestro en Colombia

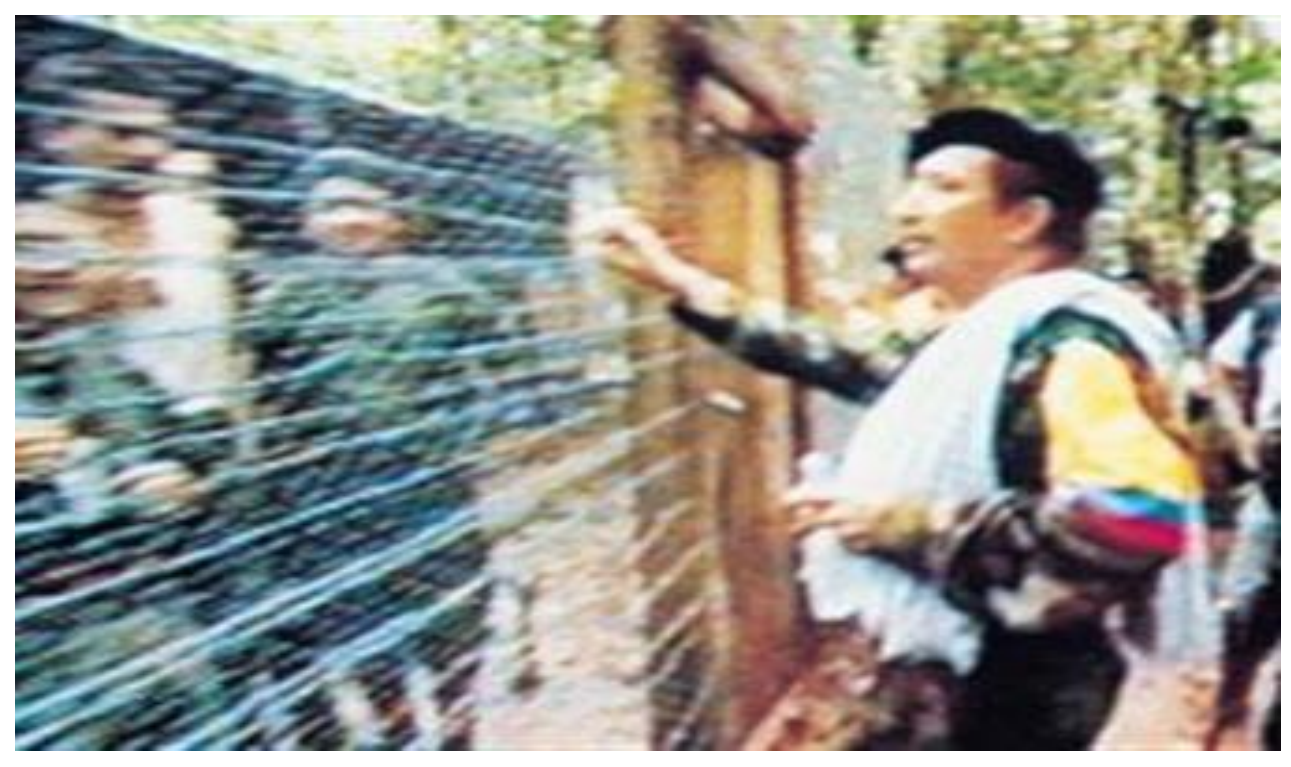

Fuente: Caracol.com, 2011

Figura 10. Soldados en campos de concentración de FARC

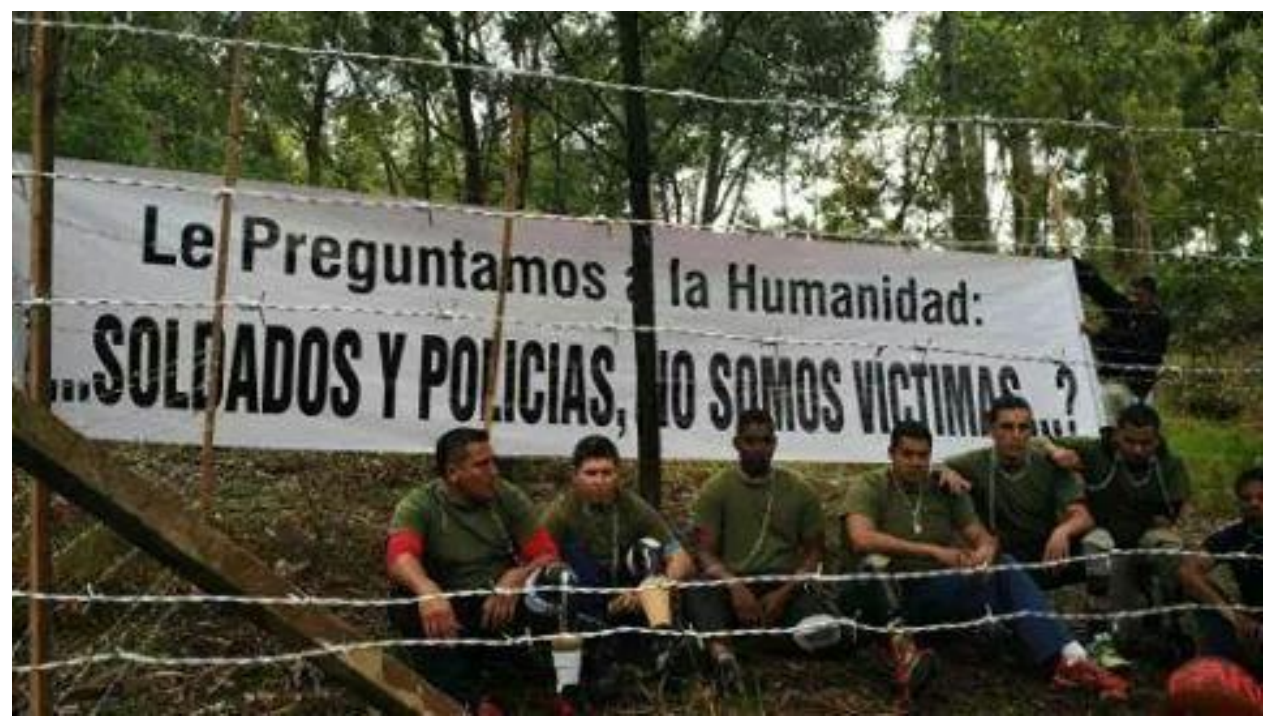

Fuente: Twitter Álvaro Uribe Vélez, 2014 
Análisis Socio Jurídico del delito de secuestro en Colombia a partir de 1970

Para el año 2007, luego de la desafortunada masacre de que fueron víctimas los diputados de la asamblea del Valle del cauca, las FARC dieron muestras de su decisión de cambiar su posición radical al realizar de forma unilateral en el año 2008, liberaciones de algunos de los secuestrados políticos, en primer lugar retornaron a sus hogares el mismo día Clara Rojas y Consuelo González (10 de enero), posteriormente Luis Eladio Pérez, a Jorge Eduardo Gechem Turbay, a Orlando Beltrán y a Gloria Polanco (27 de febrero) . Finalmente, al cabo de un año, en 2009 liberaron a Alan Jara (4 de febrero) y Sigifredo López (5 de febrero). Aunado a ello se debe destacar que el 2 de julio de 2008 en la denominada "operación Jaque" realizada por el Ejército Nacional de Colombia fueron liberados la ex candidata presidencial Ingrid Betancourt y los estadounidenses Thomas Howes, Keith Stansell y Marc Gonsalvez, junto a siete soldados y cuatro policías, y el 26 de octubre: Con la ayuda del guerrillero Wilson Bueno Largo, alias "Isaza", se fuga el excongresista Óscar Tulio Lizcano. No corrieron la misma suerte los policías Edgar Yesid Duarte Valero, Elkin Hernández Rivas y Álvaro Moreno, y el sargento mayor del Ejército José Libio Martínez quienes fueron asesinados el 26 de noviembre de 2011 por las Farc. (El Colombiano, 2012)

Luego de 2011, las Farc declararon su intención de proseguir con las liberaciones unilaterales de secuestrados y el 26 de febrero de 2012 anunciaron su renuncia al secuestro con fines de extorsión y la liberación de los diez militares y policías que mantienen secuestrado, en ese entonces las FARC a través de un comunicado público dieron a conocer su intención de abandonar el secuestro extorsivo de civiles lo que ellos llamaban "retenciones de personas, hombres o mujeres de la población civil con fines financieros “ que para el año 2000 habían ascendido a 538, en el 2002 ocurrieron 709 casos y en el 2010 ya habían descendido a 55 casos que tienen como autor a las FARC. 
Análisis Socio Jurídico del delito de secuestro en Colombia a partir de 1970

Figura 11. FARC anuncian que abandonan el secuestro extorsivo; liberarán 10 uniformados

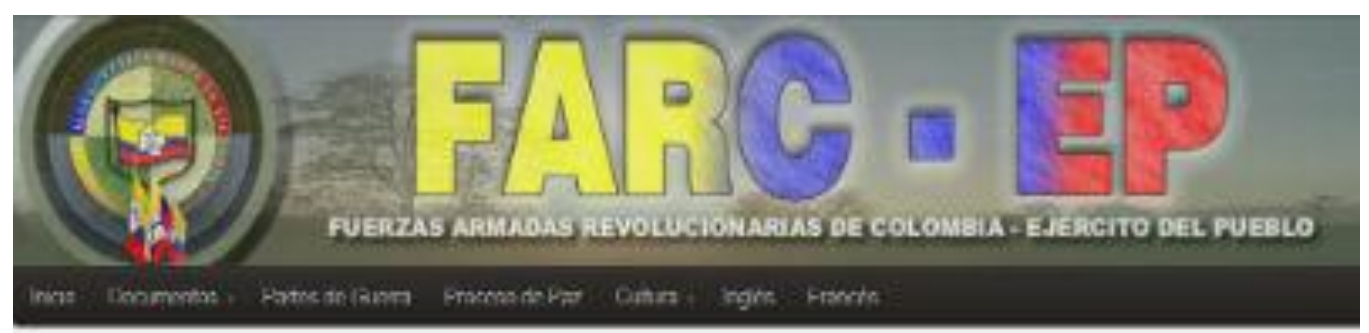

\section{DECLARACIÓN PÚBLICA \\ Sobre Prisioneros y Retenciones \\ -silesut

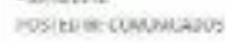

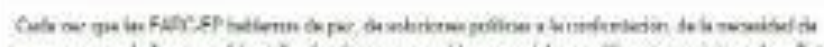

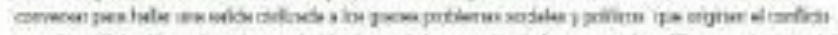

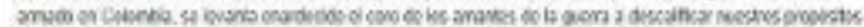

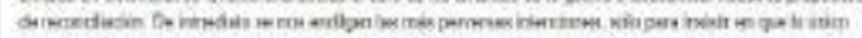

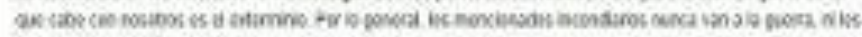
oeman rassmis

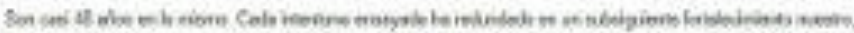

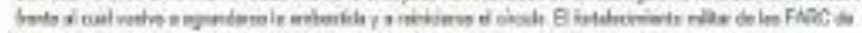

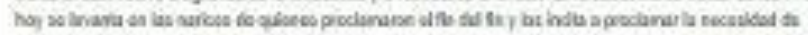

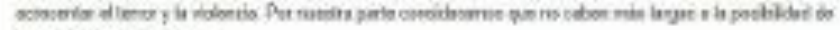
ancelar coevensdanas

Fuente: Revista Semana, 2012

Se indica por las autoridades estatales que, en la actualidad, la deplorable práctica del secuestro ha perdido protagonismo dentro de los planes criminales, por cuanto se ha venido sustituyendo por delitos como la extorsión, minería criminal y narcotráfico los cuales les proporcionan a las organizaciones criminales réditos importantes evitando los riesgos e implicaciones jurídicas que el secuestro implica.

Justamente con el secuestro de personas de la sociedad civil o funcionarios estatales, las organizaciones delictivas pretendían generar un impacto fuerte en la sociedad o implementar un mecanismo de presión al Estado, buscando generar réditos entre ellos, de orden económico para su financiación y político, como puede ser la liberación de sus miembros detenidos en las cárceles colombianas. Tal desafío a la institucionalidad genera costos de tipo político, militares e incluso 
Análisis Socio Jurídico del delito de secuestro en Colombia a partir de 1970

económicos que repercuten en contra de la guerrilla; en primer lugar los costos políticos se incrementan ya que al afectar el secuestro a miembros de la sociedad civil, como una normal reacción, esta reclamaba del Estado acciones en contra de la subversión que por demás veía como su imagen política y su credibilidad se veían destruidas; los costos militares y económicos se ven incrementados en cuanto se requería un mayor aprovisionamiento de fuerza y logística para evitar la reacción inmediata del Estado o de la fuerza pública para contrarrestar estas acciones, y destinación de hombres para custodiar a los retenidos por cuanto el cautiverio tendía a ser cada vez más prolongado, dada la ausencia de voluntad del gobierno para negociar su liberación.

Los secuestros del año 2015 han sido perpetrados en su gran mayoría por parte de la delincuencia común con un porcentaje de 74,87 por ciento, les sigue el Eln con un 14 por ciento, las bandas de crimen organizado con un 6 por ciento y por último las Farc con el 6 por ciento del total nacional. Es importante destacar que este año el 92,2 por ciento de los secuestrados en el país han sido rescatados y liberados por parte de la Fuerza Pública, demostrando un alto nivel de compromiso y efectividad operacional de estas unidades especiales. (Fuerzas Militares de Colombia, 2015, p. 3).

Según fuentes oficiales la cifra de secuestros ocurridos para 2016 fue de 188, lo cual para el director de la policía antisecuestros General Fernando Murillo se puede considerar como una cifra histórica frente a la disminución de este delito tan atroz, agregando que en ese año no reportaron secuestros por parte de las Farc, siendo la delincuencia común responsable del $88 \%$ de los casos reportados este año, el ELN del $11 \%$, y el $1 \%$ restante se origina en la delincuencia organizada. (El Tiempo, 2016) 
Análisis Socio Jurídico del delito de secuestro en Colombia a partir de 1970

Teniendo como base estas informaciones y estadísticas, podemos colegir que al terminarse por parte del responsable del $33 \%$ de los secuestros cometidos, esta se puede considerar como una real causa del descenso de las cifras de ocurrencia del ilícito, en la que afortunadamente permite cerrar una página nefasta en nuestra historia, que en poco más o menos cuatro décadas en las que las FARC cometieron este ilícito, victimizaron a millares de personas sin discriminar estratos sociales, enfatizando en figuras públicas y políticos que pudieran representar algún beneficio económico o político para la organización subversiva.

\subsubsection{Disminución en las Estadísticas de Secuestros del Eln}

En el periodo inicial de ocurrencia de los secuestros en Colombia entre 1970 y 1989, el ELN no tuvo una participación importante, debido a las capturas de varios de sus principales líderes, y a grandes derrotas militares ocurridas en los años setenta. Es en las décadas de los 70 y 80 que el ELN inicia un proceso de crecimiento y recomposición, y se asiste a una consolidación paulatina del secuestro como estrategia de combate y financiación. A lo largo del período de Inicios, llegaron a contabilizarse 356 secuestros de nacionales y extranjeros cometidos por este grupo guerrillero, en el cual las exigencias oscilaban entre $\$ 1.000$ y $\$ 5.000$ millones. En el período de Escalamiento comprendido entre los años de 1990 a 1995 al ELN se le atribuyen 781 secuestros, que lo consolidó durante esos años, como el principal autor de este delito en el país, periodo en el que además los grupos guerrilleros, particularmente las FARC y el ELN, aprovecharon el marco de oportunidad para crecer y fortalecerse a nivel militar y político, incrementando la comisión de secuestros, principalmente extorsivos, y además entraron a formar parte directa del complejo entramado que constituye la infraestructura del negocio del narcotráfico. (Centro Nacional de Memoria Histórica, 2013) 
Análisis Socio Jurídico del delito de secuestro en Colombia a partir de 1970

Las motivaciones del ELN tienen carácter difuso, ya que pueden ser económicas, políticas y reivindicatorias, preponderando las primeras, no obstante coinciden con las FARC en el empleo de las mal llamadas "pescas milagrosas" como método para la selección de sus víctimas y como modus operandi se tiene establecido que es un elemento característico de esta organización la especialización de columnas encargadas de realizar secuestros en ciertas áreas del país en donde tienen influencia y a pesar de que el ELN reclama un mayor volumen de secuestros políticos, se ha documentado cómo muchos terminan en liberación tras un pago, lo cual permite apreciar a una guerrilla que ha utilizado el secuestro como uno de sus principales mecanismos de financiación. Sobre la zona donde cometían los ilícitos, se tiene que el 55\% de los secuestros del ELN están concentrados en cuatro departamentos: Antioquia, Cesar, Santander y Norte de Santander, en menores proporciones se afectaron los departamentos de Boyacá, Arauca, Bolívar y el Valle del Cauca. (Centro Nacional de Memoria Histórica, 2013)

Del estudio de las cifras publicadas por el CNMH se puede patentizar que entre los años 1970 a 1999 el ELN cometió 3.556 secuestros de los cuales 1.238 tenía una motivación económica, 704 tenía una motivación política y 1.567 no tienen motivo determinado. Entre los años 2000 a 2010 la cifra de secuestros perpetrados por ese grupo subversivo asciende a 3.806, de los cuales 1.913 tenían una motivación económica, 146 motivación política y 1.691 sin motivo determinado. Lo anterior corrobora la tesis antes expuesta que permite considerar a una guerrilla que ha utilizado el secuestro como uno de sus principales mecanismos de financiación. Para el 2010 se tiene acreditado cometieron 35 casos de secuestro, en el 2011 ejecutaron 34 casos, en el 2012 incurrieron en 22 eventos, 6 menos que en el 2013 y en el 2014 ejecutaron 31 casos de secuestro. Para los años 2015 y 2016, se tiene que cometieron 44 casos. Es decir se redujo la cifra de 1010 casos en 2001 a 22 casos en 2016. 
Gráfica 24. Secuestros ELN 1970-1999

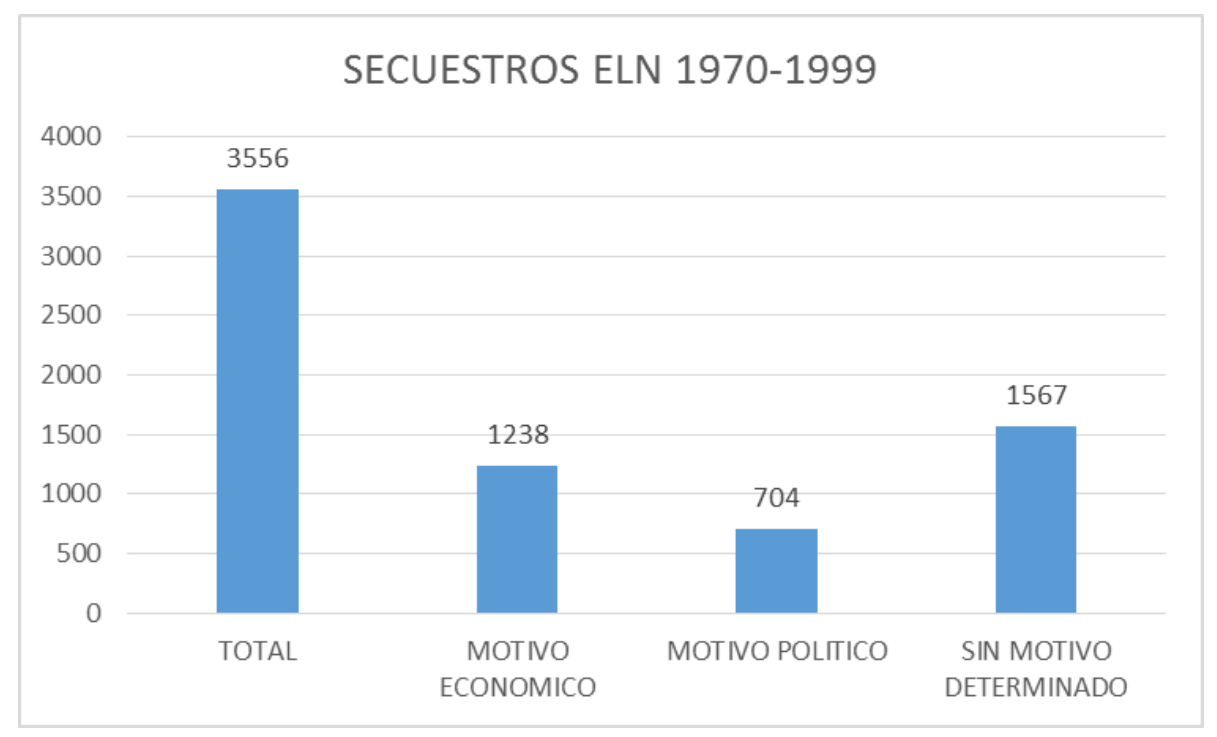

Fuente: Datos Tomados del Centro Nacional de Memoria Histórica, 2013. (Elaboración propia, 2018)

Gráfica 25. Secuestros ELN años 2000-2010

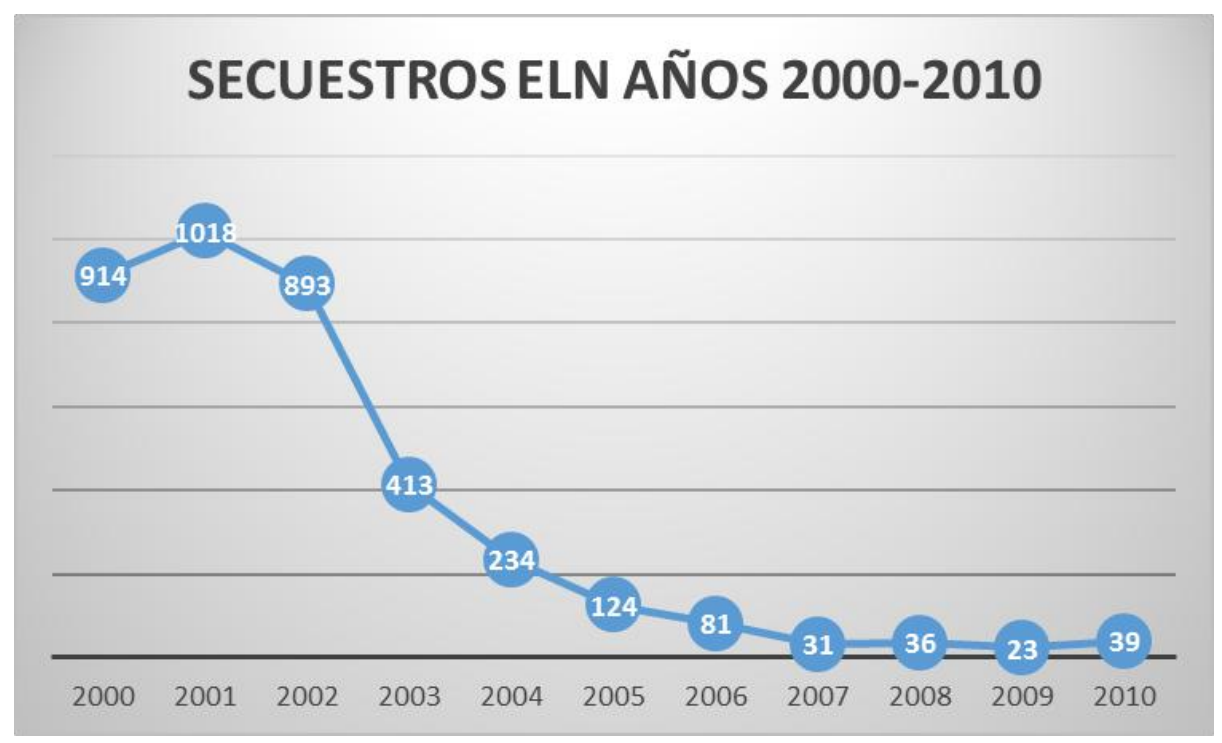

Fuente: Datos Tomados del Centro Nacional de Memoria Histórica, 2013. (Elaboración propia, 2018) 
Gráfica 26. Estadística de secuestro en Colombia 2010-2014

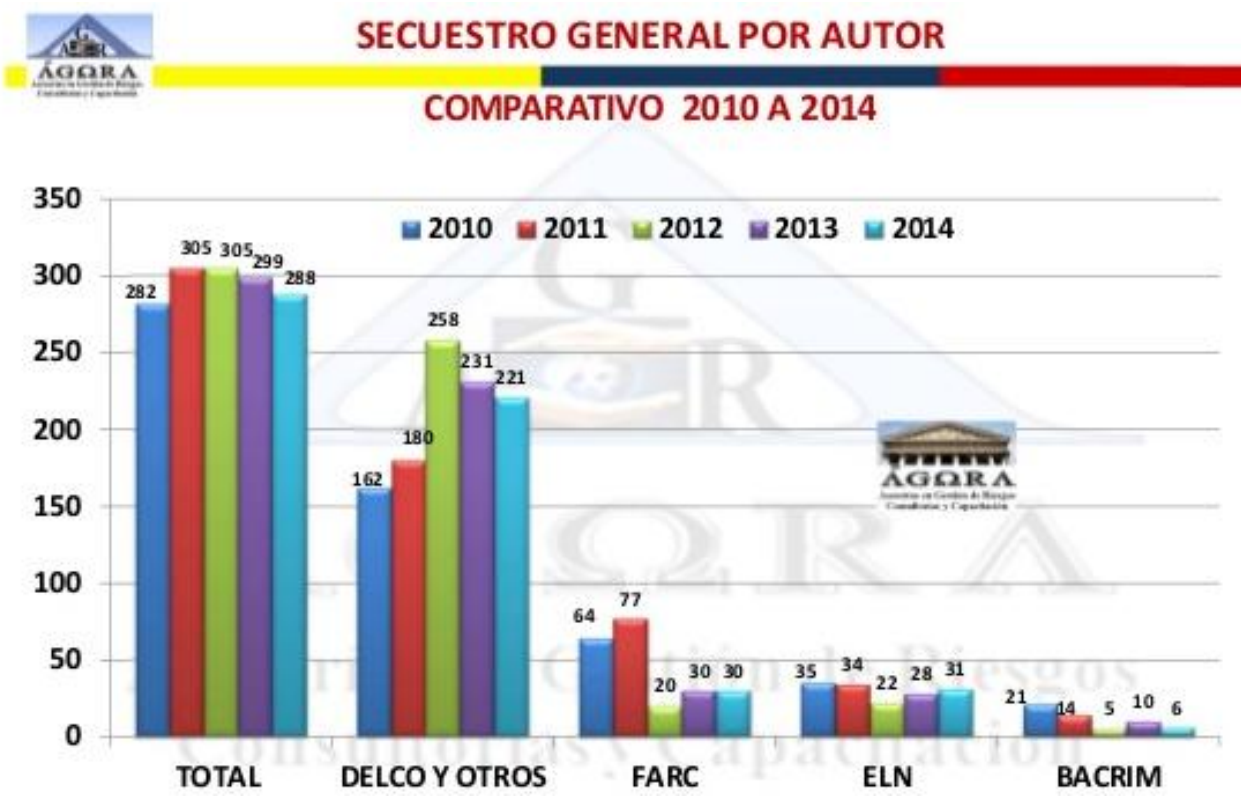

Fuente: Hernández, 2015

Gráfica 27. Estadística de secuestro en Colombia

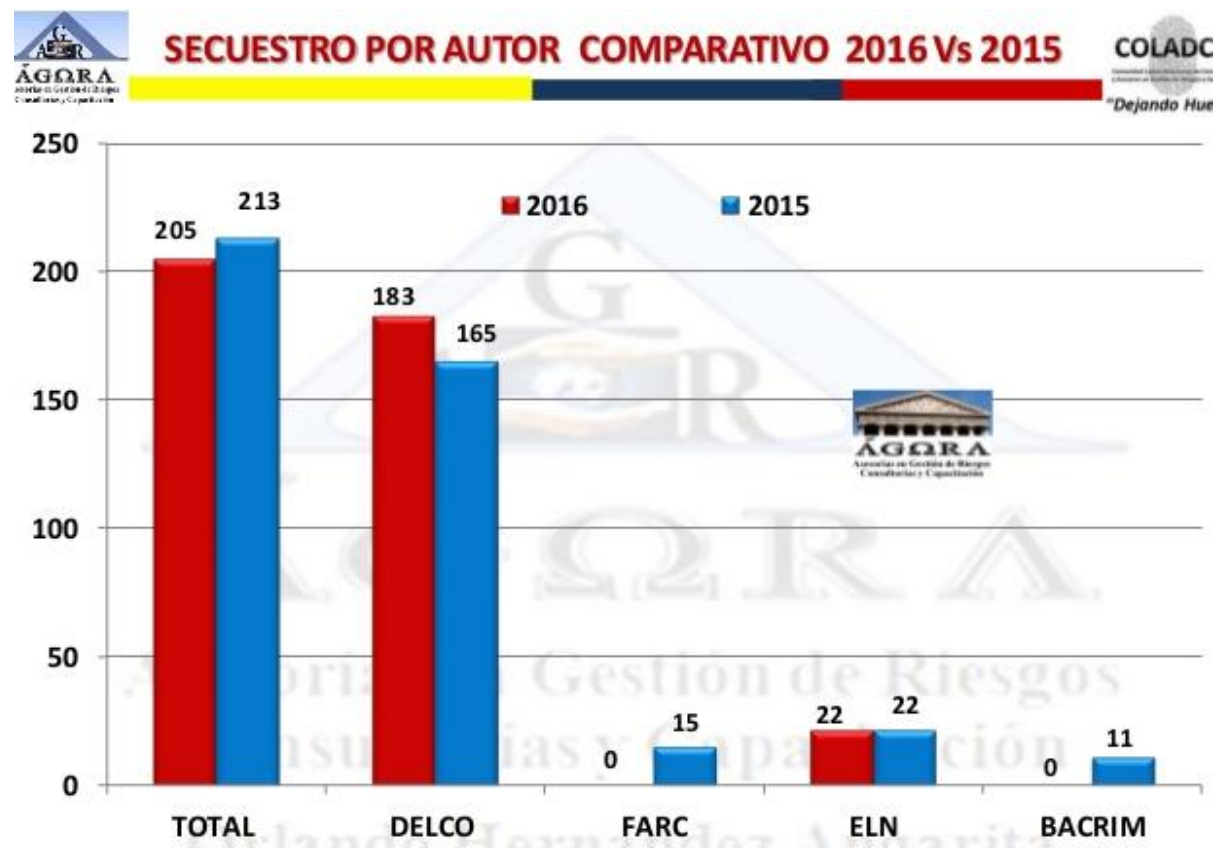

Fuente: Hernández, 2015 
Análisis Socio Jurídico del delito de secuestro en Colombia a partir de 1970

Teniendo como base estas informaciones y estadísticas, podemos colegir que al disminuirse esta cifra de secuestros cometidos por el ELN a quien se le atribuye la responsabilidad del $25 \%$ de los secuestros cometidos, esta se puede considerar como una real causa del descenso de las cifras de ocurrencia del ilícito, máxime si se le adiciona el $33 \%$ de las FARC, obteniendo una reducción de poco más o menos $58 \%$ de la totalidad de la cifra de secuestros cometidos.

\subsubsection{Utilización de otras formas de financiación por las guerrillas}

Al momento en que las Farc informaron que acabarían con el secuestro, decidieron mutar las forma de financiación hacia otras actividades igualmente ilícitas, y su sostenimiento pasó a depender aún más de las extorsiones, no solo al menudeo a pequeños y medianos comerciantes sino a las multinacionales. A principios de 2003, se afirmaba por Paul Collier, director del grupo de investigaciones del Banco Mundial, que desde 1998 a la guerrilla colombiana le ingresaron más de mil millones de dólares por extorsión a multinacionales europeas. De acuerdo con este articulo las guerrillas reciben un mínimo porcentaje de ayuda legal proveniente de ong's, pero esto corresponde a un porcentaje mínimo ya que un porcentaje mayor viene de los negocios que tienen y que se mueven dentro de la Ley dentro de los que están las cooperativas de lanchas y de taxis que administran milicianos o guerrilleros urbanos además que son dueñas de supermercados, fincas y ganadería. De estos negocios que se mueven en la legalidad también reciben recursos, los mismos que si fueran empresarios o ganaderos. (La silla vacía, 2012)

Es de anotar que recientemente la Fiscalía General de la Nación gracias a los testimonios de desmovilizados de la antigua guerrilla de las FARC, adelantó una investigación que permitió 
Análisis Socio Jurídico del delito de secuestro en Colombia a partir de 1970

identificar una red de testaferros de dicha organización, que remonta sus orígenes a la antigua zona de distensión del Caguán.

En el centro de esta red se identificó a los propietarios de la cadena de Supermercados SUPERCUNDI, MERKANDREA Y MERCAFUSA, que suman 60 locales comerciales en Bogotá, Cundinamarca (Chía, Cota, Fusagasugá, Facatativá, Girardot, La Calera, Madrid, Mosquera, Silvania, Soacha, Tibacuy, Tocainía y Villeta), Tolima (Espinal, Lérida, Melgar y Saldaña) y Quindío (Armenia y Calarcá), lo cual corrobora lo afirmado desde tiempo atrás. (Fiscalía General de la Nación, 2018)

Para el año 2013 se afirmaba que uno de los factores que explicaban que no se había dado una desarticulación de las Farc es que el grupo guerrillero seguía contando con financiación proveniente del narcotráfico, especialmente en zonas que han sido tradicionalmente utilizadas por el grupo como lugares de retaguardia. Estudios del $\mathrm{CNMH}$, afirmaban que el decrecimiento de estos recursos del narcotráfico al igual que los originados por el secuestro, habían venido siendo compensado por ingresos por concepto de la percepción de "tributos" en las zonas mineras. El artículo afirma que para las FARC, los recursos provenientes del secuestro habían decrecido significativamente desde el 2002, cuando la cifra de secuestrados alcanzaba 1.120.479 y entre el 2008 y el 2012, la tendencia continuaba a la baja aunque con un leve aumento hasta el 2011. Se destaca por otra parte que para la época el fenómeno de la extorsión crecía de la mano con los ataques a la infraestructura nacional. Así, de 207 extorsiones registradas en el 2011, se pasó a 270 casos atribuidos a las FARC durante el 2012. (Centro de Memoria histórica, 2013, p. 191) 
Análisis Socio Jurídico del delito de secuestro en Colombia a partir de 1970

Otra de las fuentes de financiación a las que ha acudido la guerrilla, tiene que ver con la extorsión que genera en las zonas de minería en donde resulta un ingreso fácil y barato de recolectar por su concentración geográfica. Destaca la fuente en cita que cálculos realizados, sostienen que las Farc percibirían, en solo dos zonas mineras ubicadas en el nordeste antioqueño y en el sur de Bolívar, ingresos mensuales de 2.100 millones y 3.500 millones, respectivamente. De igual forma, impone una tributación a los llamados "barequeros" que extraen los minerales manualmente donde las cifras o los valores de la tributación muestran variabilidad citando que en el bajo Cauca, por ejemplo, los impuestos sobre la minería del oro a la maquinaria y a los mineros que trabajan manualmente les dejarían a las Farc un ingreso mensual de 3 millones de dólares; en San Pablo, Bolívar, los mineros tienen que pagar "6 millones de pesos mensuales por retroexcavadora y mil pesos por gramo de oro extraído"; en Ataco, Tolima, una sola mina pagaba un impuesto de 120 millones de pesos diarios, y en el río Saldaña, tributaban unos 4. 000 mineros que ganaban entre 150 y 300 mil pesos diarios. Aparte de los ingresos por la tributación minera, las Farc contarían con minas propias como ocurre, al parecer, en el Vichada donde explotan oro y esmeraldas.

Por otra parte, afirma el CNMH en este estudio del año 2013, sobre la utilización del narcotráfico para la financiación de las FARC, que precisamente en regiones en donde las FARC eran fuertes se percibían ciertas conexiones con las bandas criminales y antiguos paramilitares en función del tráfico de la pasta de coca y de armas. (Centro Nacional de Memoria Histórica, 2013, p. 291)

Lo anterior era corroborado por el entonces comandante de la Armada Nacional de Colombia, que para el año 2014 aseveró que el tráfico de cocaína y la minería ilegal eran para la época las principales fuentes de financiamiento de la guerrilla, Fuerzas Armadas Revolucionarias 
Análisis Socio Jurídico del delito de secuestro en Colombia a partir de 1970

de Colombia, FARC, agregando que entre los meses de enero y abril de 2014, "se habrían incautado 14 toneladas de cocaína vinculada a las FARC, mientras que 28 guerrilleros han sido capturados, dado que el tráfico de drogas en Colombia se seguía originando principalmente por vía marítima" (Mercopress, 2014).

Ya en el 2005, mediante estudio de la unidad de análisis Financiero revelado por los medios de comunicación y que posteriormente fuera desmentido por este organismo estatal, se aseguraba que las cifras de lo que les cuesta a las Farc mantener su aparato de guerra son significativas. No obstante, los montos del dinero que reciben por diferentes actividades ilegales son astronómicos, aunque en algunos casos muy inferiores a las cifras que se conocen públicamente. Una muestra de esto es que según la investigación, los dividendos de las Farc por su participación en los principales eslabones de la cadena del narcotráfico (cobro por la seguridad de los cultivos, impuesto a laboratorios de producción y cobro del "impuesto de gramaje") llegaron a los 23.000 millones de pesos durante 2003. Se advertía en el informe revelado que aparte de los dividendos que perciben en la cadena de producción del narcotráfico existen otros ingresos derivados del tráfico de drogas. De acuerdo con la investigación de la Uiaf, las Farc controlan 57 pistas aéreas, "muchas de las cuales tienen una longitud de hasta 2.000 metros y entre 20 y 60 metros de ancho (...) el número es alto si se comparara con los 73 aeropuertos que operan en todo el país", afirma uno de los apartes de la investigación. Según los datos recolectados en el estudio, durante 2003 en 57 pistas de las Farc se efectuaron 1.077 vuelos internacionales. El impuesto que las Farc cobran por dejar utilizar esas pistas oscila entre los nueve y 11 millones de pesos por vuelo, lo que representó ganancias por 7.000 millones de pesos.

Se afirma además que aparte de los dividendos que obtiene del narcotráfico, otra importante fuente de ingresos de las Farc, según la investigación de la Uiaf, es el 
Análisis Socio Jurídico del delito de secuestro en Colombia a partir de 1970

secuestro. Durante 2003 el cobro de rescates, cuyo promedio oscila entre los 140 y 160 millones de pesos por secuestrado, le generó a la guerrilla la cifra de 88.560 millones de pesos. Al igual que con el narcotráfico, en este aspecto el monto de la investigación es muy inferior a los 620 millones de dólares que públicamente se manejaron como ganancias de las Farc por secuestros. Después de ese delito, el abigeato es la actividad ilícita que mayores recursos le produce a la subversión. En 2003 las Farc robaron 106.934 cabezas de ganado con un valor de 75.241 millones de pesos. Concluye el artículo que aunque sin duda alguna el narcotráfico es una importante fuente de financiación de la guerrilla, una de las conclusiones más importantes que deja el estudio de la Uiaf es que el secuestro y el robo de ganado deben ser atacados con igual contundencia que el tráfico de drogas. (Revista Semana, 2005)

Por su parte el ELN, como grupo subversivo aún vigente defiende el secuestro como forma de financiación y aunque en la actualidad adelanta diálogos formales con el gobierno nacional de Colombia, admite que los beneficios económicos obtenidos de una retención, son centralizados al ELN y son por consiguiente utilizados para financiar la rebelión. (Noticias RCN, 2017)

Recientemente el comandante Yeison de esa agrupación, admitió que el ELN se financia en gran parte con los rescates que pide por las personas que secuestra, pero también con las extorsiones y el cobro de lo que considera "un impuesto" a los traficantes de cocaína y a otras actividades como la minería, la ganadería y la explotación de madera en las zonas en donde tiene presencia. (Asuntos Legales, 2017) 
Análisis Socio Jurídico del delito de secuestro en Colombia a partir de 1970

Para el 2011 el entonces comandante de la Armada Nacional de Colombia respecto a la financiación del ELN afirmaba que para 2001 ese grupo se lucraba de secuestros y extorsiones en la región del Valle del Cauca y del Cauca, hechos entre los que se destacaba el secuestro de 121 feligreses en la iglesia La María y el de 94 personas en el sector del kilómetro 18 en la vía Cali-Buenaventura el 17 de septiembre del 2000. Agregó que para esa época (2011) la ubicación de ese grupo en el suroccidente colombiano está en función de su mayor fuente de financiación, donde tiene un control territorial de la siembra, el procesamiento y la venta de la droga. (El país, 2011)

En consecuencia, no es difícil advertir que en vigencia de las FARC como grupo guerrillero, en sus últimos años y ahora el ELN han mutado sus actividades de financiación, hacia otros ilícitos que generan mayores divisas tales como el narcotráfico, minería ilegal y la extorsión entre otros. Esto se explica por cuanto la comisión de estas actividades igualmente delictuales les generaba menor desgaste de su imagen política ante la sociedad, dadas la reacción legítima de la sociedad frente a este flagelo y al alto grado de animadversión en su contra, además de los costos económicos y logísticos que generaba para las guerrillas la práctica del secuestro. En el mismo sentido tenemos que la desmovilización de los grupos paramilitares, aunque posterior a ello han surgido los grupos armados pos desmovilización o BACRIM, se puede evidenciar una tendencia de desescalamiento intenso para el periodo pos desmovilización, en la cual se redujeron ostensiblemente las estadísticas de casos de las masacres al igual que el secuestro y la desaparición forzada son modalidades cuya magnitud disminuyó en el periodo de estos grupos armados. 
Análisis Socio Jurídico del delito de secuestro en Colombia a partir de 1970

Dicho esto, podemos dar respuesta afirmativa a nuestra duda inicial que planteaba la existencia de otras causas que junto a legislación permitieran explicar la reducción del fenómeno del secuestro en nuestro país. En otras palabras, la legislación no cumplió con los objetivos trazados de erradicar, prevenir la comisión del secuestro, si bien en algunos casos se disminuyó en otros se mantuvo igual o en el peor de los casos aumentó luego de la expedición de las normas, este en consecuencia no es el factor desencadenante de la disminución en las estadísticas. Por el contrario, el análisis de estas cifras permite advertir que situaciones de orden político y social como los diálogos de paz con las guerrillas, la acción del Estado a través de los grupos de policía y Ejército Nacional, así como la desmovilización de grupos paramilitares constituyen una real causa de las bajas cifras de este tipo de trasgresión del código penal, ello por cuanto se ha reducido a una mínima expresión el porcentaje de secuestros cometidos por las FARC, ELN y grupos paramilitares que llegaron a ascender al $65 \%$ del total de casos cometidos en Colombia.

En consecuencia, hay que decirlo claro: el secuestro no disminuye únicamente por los cambios en las leyes de aumento de penas o supresión de beneficios a los investigados y condenados, este es solo uno más de los factores desencadenantes de este resultado que obedece como se ha dicho a otros fenómenos sociales y políticos que si han sido verdaderamente las causas de la reducción de este flagelo que ha afectado en gran medida a nuestra sociedad. 
Análisis Socio Jurídico del delito de secuestro en Colombia a partir de 1970

\section{Capítulo VIII. El "Ser" y el Deber "Ser" del Poder Punitivo}

Dentro de este estudio, de forma empírica se ha logrado concluir luego del análisis de los datos recolectados sobre el tema de secuestro, que la legislación no ha sido un factor predominante o categórico en la reducción de los índices de secuestro en Colombia, sino que tal mengua se ha debido a otros factores que se han convertido en causas directas de ello ya sea de orden político (desmovilización y reincorporación a la vida social de grupos armados), de orden estatal (reacción a través de sus autoridades militares y de policía), sin desconocer que la legislación ha sido uno de los factores de reducción, pero sin convertirse en concluyente para el logro de este designio.

Teniendo en cuenta lo anterior, se pretende en este capítulo ofrecer desde lo teórico, una explicación sobre cuales han podido ser las causas para que la legislación expedida sobre la materia -con la cual se pretendía a través del aumento de penas principalmente erradicar, prevenir la comisión de secuestro y sancionar drásticamente a sus autores o participes- no haya podido cumplir con los objetivos propuestos. Para ello se observará si el incremento de penas ha sido un elemento decisivo en la reducción de la criminalidad, haciendo referencias desde lo dogmático sin profundizar en estos aspectos que requerirían un estudio más específico, para lograr definir cuál es el deber ser de la creación de una sanción y si estos postulados se han cumplido por parte de nuestro legislador.

Efectuado lo anterior, se buscará evidenciar si el legislador en su propósito de generar normas para la erradicación de estos delitos, ha sido consecuente con razones de política criminal estatal, o por el contrario como se ha afirmado es producto de una reacción coyuntural del estado expedida en su afán de responder a la ciudadanía que se ve afectada por cierta clase de flagelos, como el secuestro en este caso. 


\subsection{Deber ser de la pena}

En el Derecho Penal el sistema punitivo resulta ser un instrumento creado y utilizado por los Estados, que pese a afectar derechos fundamentales de los asociados resulta ser útil para proteger los bienes jurídicos que se creen son los más significativos para el desarrollo de todas las personas en sociedad. En este sentido, a través del legislador se expiden una serie de normas o estatutos represivos que permiten sancionar a quienes las transgredan, privándolos incluso de la posibilidad de disfrutar de derechos tales como la libertad, la propiedad entre otros.

Varios doctrinantes han hecho valiosos aportes sobre lo que se debe tener como principios del deber ser de la pena.

"Para Jakobs el contenido y la función de la pena no se pueden configurar con independencia de la existencia del orden en el que se pune, ni de la comprensión de su sentido" (Jakobs, 1997, p. 8).

Manuel De Rivacoba y Rivacoba (1993) afirma que:

La pena en fin es absolutamente concreto, no la amenaza que la ley designa y con que la ley conmina en abstracto para la hipótesis de una determinada especie delictiva, sino la posibilidad y magnitud incluida en ella que el juez precisa e impone en concreto por un delito particularizado, por la ocurrencia delictiva individualizada, y el condenado debe cumplir. (p. 11)

Zafaronni (2016) asevera que todos, sin poner en duda la legitimidad del poder punitivo, afirman que deber ser de modo tal que cumpla alguna función positiva y racional, admitiendo que el poder punitivo de un Estado surge como una venganza razonable donde el tiempo es la clave de la venganza y de la pena.

Para Rivacoba (1993), los conceptos de retribución y de prevención constituyen una verdadera y perfecta antítesis, y, por tanto, no admiten ningún grado de conciliación entre sí, por 
Análisis Socio Jurídico del delito de secuestro en Colombia a partir de 1970

cuanto la retribución fluye de una concepción del hombre como ser capaz de conocimiento y voluntad, de autodeterminarse y obrar conforme a valores, y, por ende, de dar cuenta, es decir, de responder de sus actos, fundando y justificando así, entre la variedad de sanciones para éstos, la sanción penal y por el contrario la prevención concibe que por procedimientos que en el fondo no difieren de los que se puede aplicar a los demás entes es factible, como en éstos, determinar su obrar (prevención general) e incluso su ser o manera de ser (prevención especial), incurriendo al cabo en el contrasentido de considerarlo determinado y a la vez exigirle que responda de lo que hace y sancionarle por ello hasta con la pena.

Claus Roxin (1997) "sostiene que el ordenamiento jurídico no solo ha de disponer de métodos y medios adecuados para la prevención del delito, sino que también ha de imponer límites al empleo de la potestad punitiva, para que el ciudadano no quede desprotegido y a merced de una intervención arbitrarita excesiva del Estado Leviatán” (p. 137).

Para Jescheck (1993) en términos generales puede señalarse que al igual que la prevención general negativa, la prevención general positiva postula la búsqueda de la prevención del delito, por sobre su mera retribución, pero se diferencian en el fin que le otorgan al castigo penal. Ello, porque para la prevención general negativa, por medio del carácter disuasorio de la conminación penal y de la consiguiente aplicación de la sanción al culpable, se evita la legitimación del delito y se alienta la aversión, que se supone normal y espontánea, contra el injusto, contribuyendo con ello, además, a poner coto a la predisposición delictiva latente en la colectividad. A diferencia de ello, en la prevención general positiva la pena tiene por objeto la afirmación y el aseguramiento de las normas básicas, de los valores fundamentales que estas protegen, subrayar su importancia y la seriedad de su protección por el mandato normativo, educar al grupo social para que los acate y los asuma como propios. 
Análisis Socio Jurídico del delito de secuestro en Colombia a partir de 1970

En Colombia, en la Carta fundamental se establecen como Principios Fundamentales relacionados con la pena al ser un Estado social de derecho, el respeto de la dignidad humana y la prevalencia del interés general y en el Estatuto penal como normas rectoras de la ley penal se destacan los Principios de las sanciones penales que deberán responder a los principios de necesidad, proporcionalidad y razonabilidad así como las funciones de la pena que no son otras que las de prevención general, retribución justa, prevención especial, reinserción social y protección al condenado. (Constitución Nacional, 1991, Artículo 1) (Código Penal Colombiano, Artículo 3 y 4)

Los postulados de la doctrina constitucional se destacan en las sentencias C-565 de 1993, C-261 y C-430 de 1996, C-144, C-157, C-237, C-285 y C-327 de 1997 relativas a las funciones de la pena, los principios de proporcionalidad y razonabilidad, así como al principio de necesidad de la pena. Sentencias conforme a las cuales la pena debe ser el resultado de la aplicación del derecho penal como ultima ratio y como tal debe ser necesaria, razonable, eficiente y proporcionada Corte Constitucional Sentencia C-144 de 1997 y al legislador le corresponde ponderar la necesidad de utilización del derecho penal para resolver los conflictos que se presenten entre las personas.

Sobre la necesidad y proporcionalidad de la pena, la Corte Constitucional dice que esta no debe ser impuesta de manera arbitraria, es decir, cuando no guarda relación con el fin perseguido por ella. (...) La pena debe ser un instrumento adecuado para servir a sus fines de prevención, retribución, protección o resocialización. Si los fines de la pena pueden conseguirse por otros medios menos costosos o menos aflictivos, la pena no es necesaria y por lo tanto no puede ser útil. La pena debe ser también proporcional lo que se obtiene con la comparación entre el daño ocasionado. (Corte Constitucional, Sentencia T 596 de 1992, M.P. Ciro Angarita Barón) 
Análisis Socio Jurídico del delito de secuestro en Colombia a partir de 1970

La Corte Constitucional Colombiana, ha analizado los fines constitucionales de la pena con específica atención a los objetivos de resocialización ó función preventiva especial. Es así como en 1996 expuso que la resocialización guarda una íntima relevancia con la dignidad humana y el libre desarrollo de la personalidad, pues la reeducación y la reinserción social del condenado son el objetivo de los esfuerzos legales e institucionales del Estado. (Corte Constitucional, Sentencia C-261 de 1996, M.P. Alejandro Martínez Caballero). En el mismo año, esa corporación aseveró que la pena en nuestro sistema jurídico tiene un fin preventivo, representado en el establecimiento legal de la sanción penal, un fin retributivo que se manifiesta con la imposición judicial de la pena y un fin resocializador que orienta la ejecución de esta, a partir de principios humanistas contenidos en la Carta y en los tratados internacionales. (Corte Constitucional, Sentencia C-430 de 1996, M.P. Carlos Gaviria Díaz)

Posteriormente en la sentencia C-144 de 1997, la Corte manifestó que las penas tienen como finalidad la búsqueda de la resocialización del condenado, dentro del respeto por su autonomía y dignidad, puesto que el objeto del derecho penal en el Estado Social de Derecho no es excluir al delincuente del pacto social sino buscar su reinserción y para el año 2002 manifestó que la pena debe pretender la resocialización del condenado, dentro de la órbita del respeto de su autonomía y dignidad, puesto que el objeto del derecho penal no es la exclusión del infractor, sino su reinserción al pacto. (Corte Constitucional, Sentencia C-806 de 2002, M.P. Clara Inés Vargas Hernández)

Recientemente en 2016, la Corte concluye que la pena implica una reacción del Estado ante la infracción del ordenamiento jurídico, lo que en algunos casos es consecuencia de la pretensión de reafirmación de su facultad punitiva. Ahora para justificar las finalidades de la pena, se encuentran diferentes teorías. De una parte, las absolutas que tienden a la retribución y la 
Análisis Socio Jurídico del delito de secuestro en Colombia a partir de 1970

prevención y de otra, aquellas que se fundamentan en la simbiosis de ambos postulados. El Código Penal colombiano le otorga a la pena funciones de prevención general, retribución justa, prevención especial, reinserción social y protección al condenado. Por su parte, la Corte ha estudiado el fenómeno de los fines de la pena y ha admitido que la resocialización es un fin constitucionalmente válido de la pena. (Corte Constitucional, Sentencia C-328 de 2016, M.P. Gloria Stella Ortiz Delgado)

\subsection{El "Ser" del poder punitivo en Colombia}

Retomando la noción del deber ser de la pena a nivel general, se tiene que este instrumento pese a afectar derechos fundamentales permiten sancionar a quienes las transgredan, privándolos incluso de la posibilidad de disfrutar de derechos tales como la libertad, la propiedad entre otros, ello con miras a satisfacer los intereses colectivos y proteger los bienes jurídicos de los asociados. En ese orden de ideas resulta significativo identificar que está sucediendo en nuestro país en el ejercicio legislativo relacionado con el tema punitivo.

Sobre el punto vale la pena destacar que la actividad legislativa del congreso colombiano ha hecho énfasis en el aumento de las penas como factor de disuasión frente al transgresor de la ley penal, dentro de esta actividad se han detectado por parte de los operadores judiciales una serie de problemas, que entre otros son: la falta de coherencia en la asignación de penas, entre la gravedad y peligrosidad de la conducta y la sanción a imponer, así como la falta de proporcionalidad entre el hecho delictivo y la sanción o pena establecida; ello deja ver un grado de desorientación en los criterios que deben orientar la asignación de penas y permite avizorar que el aumento de la pena en ciertos delitos se hace con el fin de que sirva como una amenaza o un factor de persuasión para quien pretenda cometer ilícitos, lo que demuestran no sólo ausencia de 
Análisis Socio Jurídico del delito de secuestro en Colombia a partir de 1970

política criminal, sino también carencia de criterios claros en materia de rehabilitación. Por otra parte se ha detectado, la influencia de determinados grupos que de acuerdo con su interés, ejercen sobre la labor legislativa, lo cual genera una falta de credibilidad en la razón de ser de la política criminal, y que la fijación de las penas no responden realmente a la entidad del daño ocasionado a una determinada víctima, aspectos que permiten afirmar que, en nuestro Estado democrático, las soluciones suelen diseñarse ex post y no ex ante, es decir, no se estructura una política criminal preventiva, sino sólo represiva. (Política Criminal del Estado Colombiano, 2017)

Sobre el aumento de penas realizado de manera indiscriminada y sin atender un estudio ponderado de política criminal, diferentes doctrinantes han sido coincidentes en destacar que dicho incremento del monto no genera un efecto directo en la disminución del delito como fenómeno social, Zaffaroni (2009) afirma que la ciencia jurídico-penal de nuestros días parece moverse entre dos polos fundamentales: (a) Uno que comenta asépticamente las leyes y las armoniza en un mundo normativo, aceptando con entusiasmo o con resignación la expansión inusual de la legislación penal y hasta la reintroducción del enemigo en el orden jurídico del estado de derecho. (b) Otro que resiste la expansión sin dejar de legitimar el ejercicio del poder punitivo, aunque en la medida limitada de la retribución justa. Agrega que la ciencia jurídico-penal cumple su función política de proyectar jurisprudencia (actos de poder estatal) según cómo cada autor imagina que deber ser el poder punitivo, sin incorporar ningún dato del mundo del ser (de cómo es o se ejerce el poder punitivo). Todos presuponen la validez de la prohibición metodológica de incorporar a sus teorizaciones los datos del mundo que el legislador no incorpora

De acuerdo con Gerardo Palacios Pámanes, esta tendencia punitiva consiste en la decisión que tiene el legislador para reformar las leyes penales elevando el uso de la prisión preventiva y el de la pena de prisión “(...) aun sabiendo que esta acción es inútil para disminuir los delitos o, al 
Análisis Socio Jurídico del delito de secuestro en Colombia a partir de 1970

menos, ignorando si existe una relación causal entre una reforma en este sentido y la disminución de la criminalidad" (Palacios, 2014, p. 372).

La CNDH de México, destaca que mientras se ha incrementado la frecuencia de uso y duración de la pena privativa de libertad, así como reformado las leyes penales para prohibir la libertad anticipada en algunos delitos, se han provocado respuestas violentas en la población interna, convirtiendo a la prisión en una institución que no cumple con los fines declarados para su función. (CNDH, 2016)

Para Fernando Miró director del Centro Criminal para el Estudio y Prevención de la Delincuencia, en la Universidad Manuel Hernández de España, endurecer las penas no tiene el efecto que cree el legislador, pero hacer más controles sí. Pero lo que más efecto tiene son dos cosas. Primero, el comportamiento de los iguales: y después lo que yo considero que está bien. Cumplimos las normas que nos parecen legítimas, ¿y si no cómo se explica la piratería intelectual? Hay que incidir en crear una moral social, y el mejor camino no creo que sea el derecho penal. Es posible que las medidas educativas y de estigmatizar ciertos comportamientos sean lo que nos dé los frutos y no incrementar las penas. (Información, 2013)

En consecuencia, se puede advertir que la noción del aumento de penas que se ha defendido a nivel orbital. No ha conseguido explicar su eficacia bajo un marco metodológico científico, ya que el análisis de los efectos de la creación de legislación reafirma que estos cambios en la legislación se hacen desde un punto de vista jurídico figurado más que una táctica eficaz para controlar la delincuencia y responden simplemente a la demanda pública y no a principios de racionalidad en el marco de la criminología basada en evidencia. 
Análisis Socio Jurídico del delito de secuestro en Colombia a partir de 1970

\subsection{Las penas en algunos países}

El Ministerio de Justicia de Colombia en informe realizado en el año 2017 sobre la proporcionalidad de las penas en la legislación penal colombiana, hace una comparación cuantitativa de las penas asignadas en algunos países, destacando que los máximos de las penas se fijan en muchos países por debajo de los límites legales señalados en el Código Penal colombiano. Subraya este estudio que, en materia de la cantidad de la pena imponible en la parte general del Código, se encuentran diversos límites, pero, por lo general, los más altos se encuentran en América Latina. Así, en los países de Europa, Andorra tiene señalado el máximo de la pena en veinticinco (25) años; Bélgica, reclusión temporal hasta treinta (30) años; España, prisión hasta veinticinco (25) años; Francia, reclusión criminal, hasta treinta (30) años, salvo los casos de prisión perpetua; Bulgaria, prisión hasta por veinte (20) años, excepto en los eventos de prisión perpetua; Eslovenia, prisión hasta treinta (30) años. En Asia, Bután registra prisión temporal hasta quince (15) años (salvo los casos de prisión perpetua); Federación Rusa, privación de la libertad hasta por treinta (30) años; Turquía, con pena de prisión perpetua y pena de prisión hasta un máximo de veinte (20) años; Armenia, con privación máxima de la libertad de quince (15) años, o veinte (20) en caso de concurso, y pena de prisión perpetua; Georgia, veinticinco (25) años y treinta (30) en caso de concurso; Tayikistán, con pena de veinte (20) años y veinticinco (25) en caso de concurso. En África está Angola, con prisión hasta por veinticinco (25) años; Burundi, servidumbre penal, hasta por treinta (30) años, salvo los casos de cadena perpetua; República Democrática de Congo, trabajos forzados hasta por veinte (20) años; Argelia, prisión hasta veinte (20) años, salvo los casos de pena de muerte y cadena perpetua; Etiopía, prisión rigurosa hasta por veinticinco (25) años; Gabón, prisión hasta diez (10) años, salvo los casos de pena de muerte. En América Latina, finalmente, se puede señalar a Bolivia, presido hasta treinta (30) años; Costa Rica, prisión hasta 
Análisis Socio Jurídico del delito de secuestro en Colombia a partir de 1970

cincuenta (50) años; Cuba26, privación temporal de libertad, hasta treinta (30) años, salvo los casos de pena indeterminada superior por razones de la gravedad extraordinaria del hecho, la reincidencia o el concurso de delitos; Ecuador, reclusión mayor hasta cuarenta (40) años; El Salvador, prisión hasta sesenta (60) años; Guatemala, prisión hasta por cincuenta (50) años, y Honduras, con reclusión hasta por veinte (20) años. (Cita y Gonzales, 2017)

El informe sintetiza esta información en un gráfico, así:

Gráfica 28. Comparación de penas máximas en algunos países

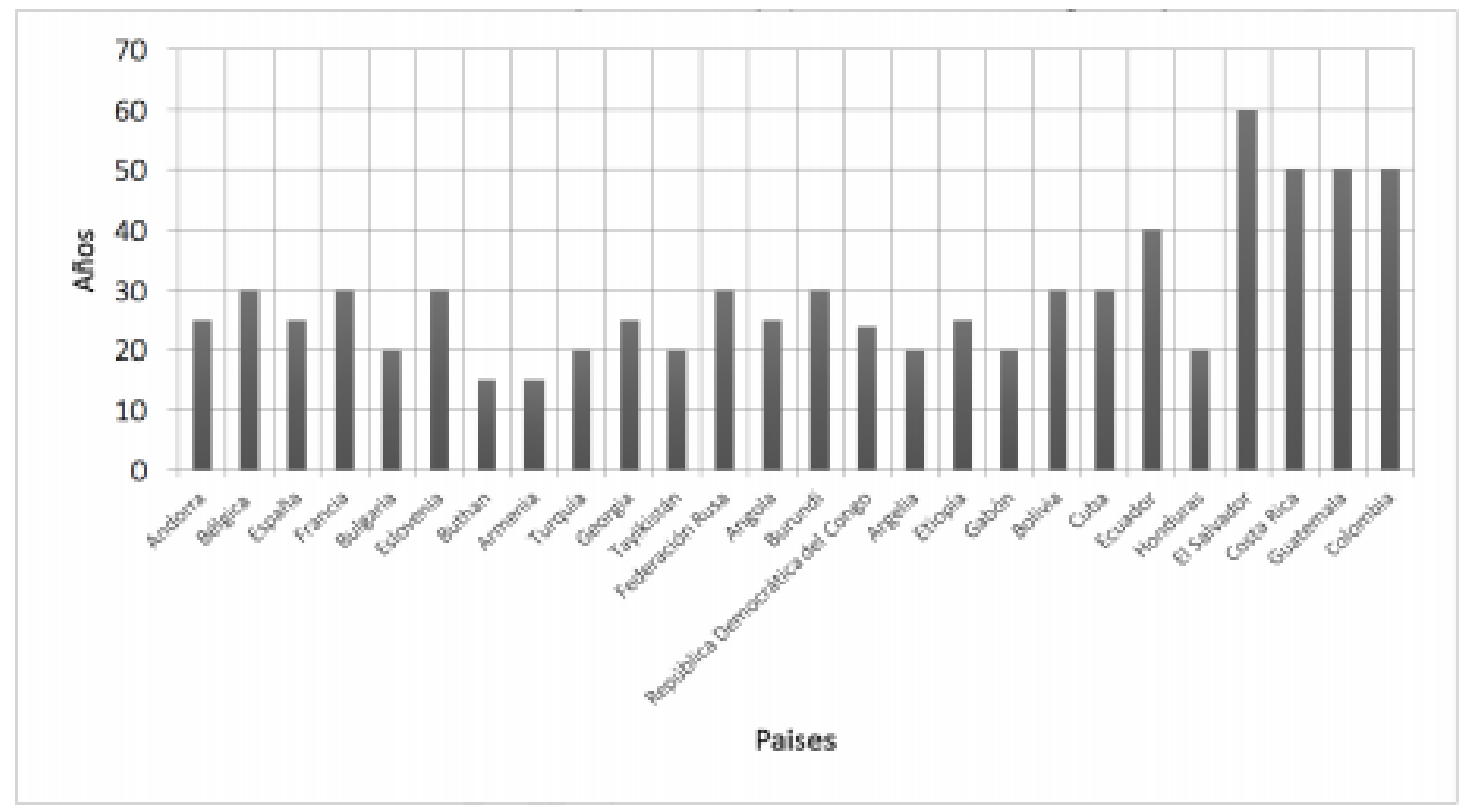

Fuente: Cita y Gonzales, 2017

Una de las conclusiones a que llega este informe utilizando para ello un simple cálculo aritmético, es que se puede afirmar que el promedio del máximo de la pena para estos países consultados es un poco superior a veintinueve (29) años, destacando que Guatemala (50 años), Colombia (50 años, el límite legal general) y El Salvador (60 años) hacen incrementar ese promedio en casi cinco (5) puntos porcentuales, pues sin ellos el máximo de la pena tendría una duración máxima promedio un poco superior a veintitrés $(24,95)$ años. Asevera así mismo, que 
Análisis Socio Jurídico del delito de secuestro en Colombia a partir de 1970

los países de América Latina son los que tienen penas privativas de la libertad más altas, saliéndose de la línea media de todos los otros países, independientemente del continente al que pertenezcan. Esto es un llamado de alerta sobre la forma como los países de la región controlan o tratan de controlar el delito, poniendo exagerada fe en el poder preventivo general de la legislación penal, y poca atención a la efectividad de judicialización o al establecimiento de controles policiales a la realización de los delitos. (Cita y Gonzales, 2017)

\subsection{Reformas al Código Penal en Colombia}

Con la adopción de la Ley 599 de 2000 se generaron cambios importantes en la concepción que en el campo jurídico se tiene de la ley penal, ya que traía consigo una nueva mentalidad adaptada a los principios y valores consagrados en la Constitución de 1991 y se incorporaron toda una serie de garantías penales materiales a manera de normas rectoras del mismo, vale decir, el principio de la dignidad humana (artículo 1) como eje rector del sistema penal, seguido por el principio de integración (artículo 2), que incorpora al Código los derechos humanos y los convenios internacionales sobre derechos humanos ratificados por Colombia; el Código Penal también estipula que los principios de necesidad, razonabilidad y proporcionalidad deben guiar la imposición de las penas y medidas de seguridad (artículo 3); establece, entre otras, como funciones de la pena la reinserción social y la protección al condenado (artículo 4) (Art. 5); fija como funciones de las medidas de seguridad la protección, curación, tutela y rehabilitación; y destaca la igualdad como un derecho y un principio a tener en cuenta, en los términos establecidos por la Constitución, en las decisiones que tomen los funcionarios judiciales. Quiere decir esto que con la Ley 599 de 2000 se pretendía 
Análisis Socio Jurídico del delito de secuestro en Colombia a partir de 1970

sancionar un Código inspirado en los principios constitucionales y que sirviera de base

a un sistema penal garantista y estable que no cayera en las trampas del régimen anterior, en el que los continuos aumentos de penas y creación de tipos penales obedecían al momento coyuntural y el sentido de crisis continua que se vivía en el país. (Universidad de los Andes, 2011, p. 5)

Sin embargo, tal finalidad en buena parte se ha quedado en el papel. La Parte Especial del Código ha cambiado constantemente, haciendo de éste un compendio cada vez más represor, que cambia según las condiciones políticas y los ánimos de los legisladores. En la última década hemos sido testigos del aumento del discurso punitivo que ha sido asumido no sólo en Colombia sino en buena parte de los países democráticos, lo cual ha alimentado los miedos de la población y ha transformado los males sociales en males que se combaten con remedios de "mano dura". (Lemaitre, 2011, p. 5)

En Colombia, el libro II del Código Penal ley 599 de 2000 que contiene el catálogo de conductas punibles, hasta el año 2016 había sido reformado en cincuenta y tres (53) ocasiones por leyes ordinarias y hasta la fecha, 6 de estas reformas han sido declaradas inexequibles. Así mismo, el Gobierno Nacional lo ha modificado siete veces a través de decretos, seis de ellos en el marco de estado de excepción. (Cita y Gonzáles, 2017, p. 59)

La siguiente tabla publicada por el Ministerio de Justicia, expresa lo anterior, 
Análisis Socio Jurídico del delito de secuestro en Colombia a partir de 1970

Tabla 2. Leyes ordinarias que modifican la parte especial del Código Penal

\begin{tabular}{|c|c|c|c|c|c|c|c|c|c|c|c|c|c|c|c|}
\hline 2001 & 2002 & 2003 & 2004 & 2005 & 2006 & 2007 & 2008 & 2009 & 2010 & 2011 & 2012 & 2013 & 2014 & 2015 & 2016 \\
\hline 679 & $\begin{array}{l}733 \\
738 \\
747 \\
759 \\
777 \\
788\end{array}$ & 813 & $\begin{array}{l}882 \\
890\end{array}$ & $\begin{array}{l}964 \\
985 \\
975\end{array}$ & $\begin{array}{l}1028 \\
1032 \\
1098 \\
1111 \\
1121\end{array}$ & $\begin{array}{l}1142 \\
1154 \\
1181\end{array}$ & $\begin{array}{l}1200 \\
1220 \\
1236 \\
1257\end{array}$ & $\begin{array}{l}1273 \\
1288 \\
1309 \\
1311 \\
1326 \\
1329 \\
1336 \\
1356 \\
1357\end{array}$ & $\begin{array}{l}1393 \\
1426\end{array}$ & $\begin{array}{l}1453 \\
1474 \\
1482 \\
1445\end{array}$ & $\begin{array}{l}1520 \\
1542\end{array}$ & $\begin{array}{l}1675 \\
1696 \\
1639\end{array}$ & $\begin{array}{l}1719 \\
1709\end{array}$ & $\begin{array}{l}1752 \\
1761 \\
1762\end{array}$ & $\begin{array}{l}1773 \\
1774 \\
1778\end{array}$ \\
\hline 1 & 6 & 1 & 2 & 3 & 5 & 3 & 4 & 9 & 2 & 4 & 2 & 3 & 2 & 3 & 3 \\
\hline
\end{tabular}

Fuente: Cita y Gonzáles, 2017

Se enfatiza por el Ministerio de Justicia de Colombia, que la política penal en el país es impulsada preferentemente por el Congreso de la República con el 54,71\% de las iniciativas legislativas y el Gobierno Nacional, quien es autor del 41,50\% de las propuestas de leyes penales. Desde este punto de vista, en un país en donde la política criminal se construye y maneja a partir, preferencialmente de las leyes penales, se puede colegir también que la política criminal está dirigida por estas dos ramas del poder público y poca injerencia tiene otros organismos o la iniciativa popular. Igualmente se concluye que, según ha sido el número de reformas introducidas al Código Penal expedido mediante la Ley 599 de 2000, el comportamiento del legislativo colombiano no dista mucho de lo que ocurre en otros países en materia penal, bien comparando la situación con países de la región, o con países europeos y, por encontrarse en la media de lo que ocurre en otras naciones, no debería alarmar, por sí misma, esta actividad del Congreso. 
Análisis Socio Jurídico del delito de secuestro en Colombia a partir de 1970

\subsection{Incremento punitivo como estrategia para combatir el secuestro en Colombia: ¿paso hacia la eficacia o populismo punitivo?}

Si hablamos de eficacia de la norma penal no podemos dejar de mencionar que el Derecho penal se inscribe dentro de un sistema de control social. Como dice Muñoz Conde (1985), “dentro del control social el sistema jurídico penal ocupa un lugar secundario, puramente confirmador y asegurador de otras instancias mucho más sutiles y eficaces” (p. 17); “es inimaginable un Derecho penal completamente desconectado de las demás instancias de control”. (p. 37).

Prevenir el delito, como dice García-Pablos de Molina (1996):

Es algo más que dificultar su comisión o que disuadir al infractor potencial con la amenaza del castigo: la prevención no puede desligarse de la génesis del fenómeno criminal, con lo cual, reclama una intervención dinámica y positiva que neutralice sus raíces. (p. 83 y 96)

Considera este autor que una moderna política criminal de prevención del delito implica, entre otras cosas, prestaciones positivas, aportaciones y esfuerzos solidarios que neutralicen situaciones carenciales, conflictos, desequilibrios, necesidades básicas. De esto, la promulgación de nuevas leyes penales, el incremento de las penas, del número de policías y de las cárceles no disminuirá la criminalidad, pues la pena no convence o disuade, "refleja más la impotencia, el fracaso y la ausencia de soluciones, que la convicción y la energía necesarias para abordar los problemas sociales”. (p. 251252)

Según el análisis realizado por Cesar Caballero de cifras y conceptos, pese a la gran escala de ocurrencia de este delito, en los últimos 40 años se han proferido apenas 3.144 sentencias, es decir, en uno de cada diez casos, advirtiendo que los procesos judiciales se demoran, en promedio, 
Análisis Socio Jurídico del delito de secuestro en Colombia a partir de 1970

seis años, y sólo en 40 casos se han condenado autores intelectuales. En el mismo sentido se afirma que la industria del secuestro floreció a la escala en que lo hizo en Colombia debido, en parte, a la colosal impunidad que la rodea. En promedio, en el $60 \%$ de los casos, los secuestrados fueron liberados tras pagar. En el caso de la guerrilla esta proporción ronda el 70\%. Sólo el 20\% de los secuestrados fueron rescatados por las autoridades.

Gráfica 29. Desenlace secuestros 1970-2010

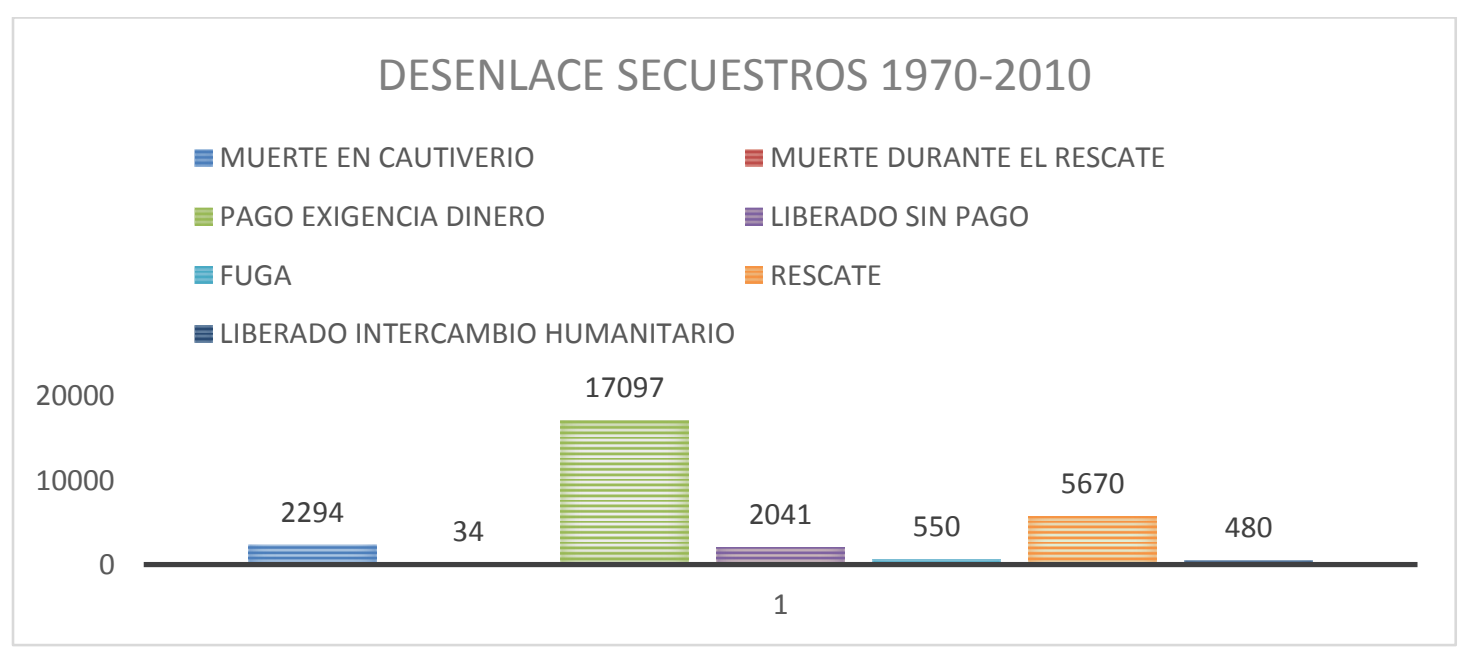

Fuente: Datos tomados del Centro Nacional de Memoria Histórica, 2013 (Elaboración Propia, 2018) 
Gráfica 30. Exigencias secuestros 1970-2010

\section{EXIGENCIAS SECUESTROS 1970-2010}

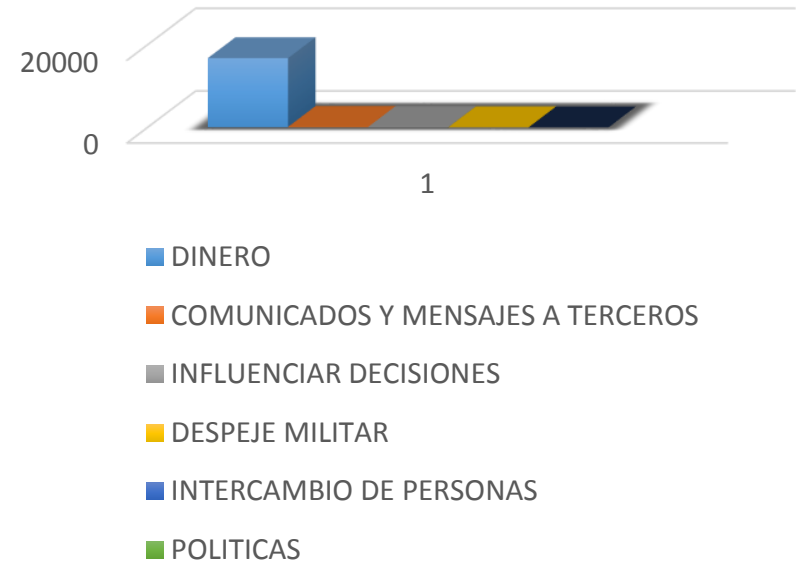

Fuente: Datos tomados del Centro Nacional de Memoria Histórica, 2013 (Elaboración Propia, 2018)

En nuestro país, el congreso ha confiado a las leyes poderes especiales para fenecer los conflictos sociales que nos aquejan y se le ha ofrecido a la sociedad a manera de "caja de pandora" en donde aún se encuentra oculta la esperanza de solución a todos los males que afligen a la Nación. Sin embargo hay clara evidencia de que en general los colombianos no confían en el sistema penal, tal cual lo indica la tasa de no denuncia en la principales ciudades del país que presenta el DANE para el 2016 y que en Bogotá alcanza el 67.8\%, en Medellín el 76.3 \% y en Cali el 73\% , al igual que es demasiado extenso el índice de percepción de inseguridad, que en 2016 encontró que para las 28 ciudades, el 62,7\% de la población de 15 años y más informó sentirse inseguro en su ciudad durante 2016. Por sexo, el 64,5\% de las mujeres de 15 años y más informaron sentirse inseguras en su ciudad, frente a un 60,7\% de los hombres de 15 años y más. (DANE, 2017)

Ya para el año 2013, el 18,5 por ciento de los colombianos consultados en 20 ciudades. 
Análisis Socio Jurídico del delito de secuestro en Colombia a partir de 1970

Gráfica 31. Tasa de denuncia por ciudad

Población de 15 años y más

28 ciudades

\begin{tabular}{|c|c|c|c|c|}
\hline Ciudad & & Tasa de denuncia & $\begin{array}{c}\text { Variación } \\
\text { puntos } \\
\text { porcentuales } \\
2016-2015 \\
\end{array}$ & $\begin{array}{c}\text { Variación } \\
\text { estadisticamente } \\
\text { significativa }\end{array}$ \\
\hline Total 28 ciudades & 29,0 & & 4,3 & sí \\
\hline Tuluá & 40,8 & & 11,2 & NO \\
\hline San Andrés & 39,3 & & $-3,7$ & NO \\
\hline Sincelejo & 33,4 & & 2,2 & NO \\
\hline Bogotá D.C. & 32,2 & & 6,4 & sí \\
\hline Tunja & 31,9 & & 3,3 & NO \\
\hline Bucaramanga & 31,7 & & 3,0 & NO \\
\hline Barranquilla & 30,9 & & 5,9 & NO \\
\hline Pereira & 29,8 & & 4,7 & NO \\
\hline Manizales & 27,9 & & 6,4 & sí \\
\hline Neiva & 27,7 & & $-6,2$ & si \\
\hline Riohacha & 27,6 & & 2,6 & NO \\
\hline Villavicencio & 27,0 & & 0,4 & NO \\
\hline Cali & 27,0 & & 8,6 & sí \\
\hline Palmira & 26,6 & & 5,6 & NO \\
\hline Santa Marta & 26,4 & & $-0,2$ & NO \\
\hline Ibagué & 26,3 & & 2,6 & NO \\
\hline Valledupar & 25,6 & & 1,2 & NO \\
\hline Popayán & 25,1 & & 0,5 & NO \\
\hline Cúcuta & 23,7 & & 0,6 & NO \\
\hline Medellin & 23,7 & & $-1,0$ & NO \\
\hline Soledad & 23,3 & & 0,1 & NO \\
\hline Quibdó & 23,1 & & 1,9 & NO \\
\hline Armenia & 22,5 & & $-2,6$ & NO \\
\hline Monteria & 21,6 & & $-3,3$ & NO \\
\hline Pasto & 21,3 & & $-0,8$ & NO \\
\hline Cartagena & 20,7 & & $-3,5$ & NO \\
\hline Buenaventura & 20,3 & & 2,8 & NO \\
\hline Soacha & 18,7 & & $-6,1$ & sí \\
\hline
\end{tabular}

Fuente: DANE- Encuesta de Convivencia y Seguridad Ciudadana - 2017

Población de referencia: 3.011 miles de personas de 15 afios y más victimas de al menos un delito.

Fuente: DANE, 2017 
Gráfica 32. Tasa de percepción de inseguridad en la ciudad por sexo

Población de 15 años y más

Total 28 ciudades

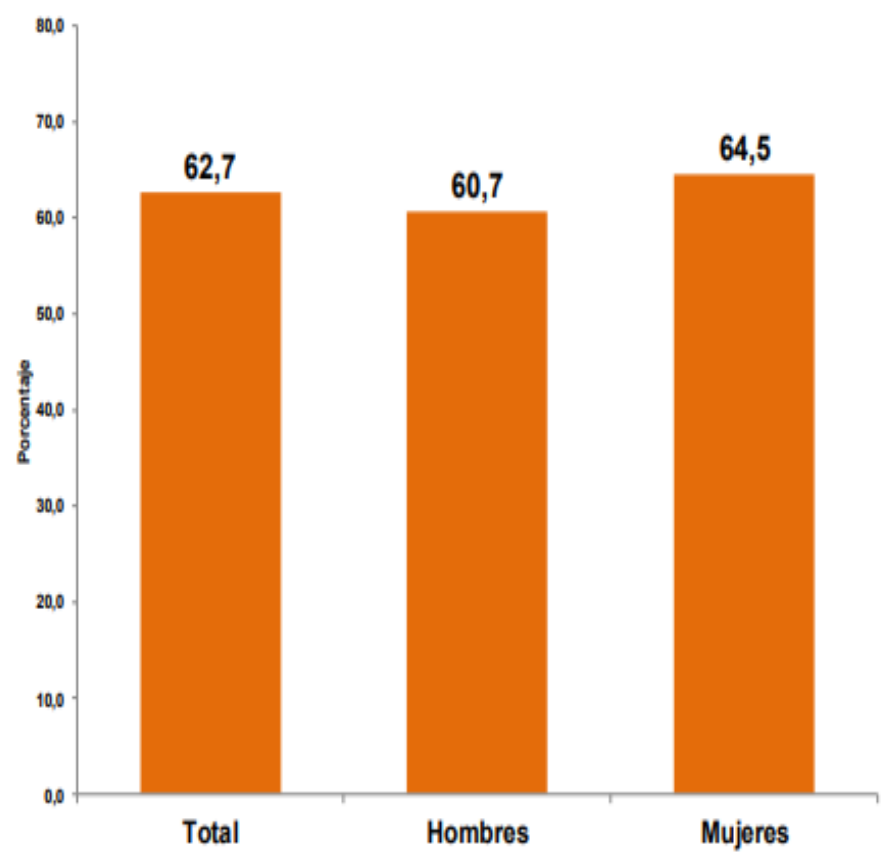

Fuente: DANE- Encuesta de Convivencia y Seguridad Ciudadana - 2017

Población de referencia: 17.996 miles de personas de 15 años y más para el total de 28 ciudades. 11.288 miles de personas de 15 an̂os y más que informaron sentirse inseguras en su ciudad.

Fuente: DANE, 2017

Ya para el año 2013, el 18,5 por ciento de los colombianos consultados en 20 ciudades dijeron haber sido víctimas de algún delito, el entonces alto consejero para la Seguridad Ciudadana, Francisco Lloreda, analizando los indicadores de la II Encuesta de Seguridad y Convivencia realizada por el DANE, manifestó en medios abiertos de prensa que las medidas adoptadas por el Gobierno en este campo han dado buenos resultados, no obstante reconoció que las bajas denuncias se deben a que la gente desconfía de las autoridades, consideran que la 
Análisis Socio Jurídico del delito de secuestro en Colombia a partir de 1970

denuncia no va a cambiar las cosas, no saben cuáles son los caminos para denunciar o los consideran engorrosos o simplemente prefieren hacerlo. (El Colombiano, 2013)

En consecuencia, el aumento de penas por sí solo no se puede erigir como la única forma eficaz para la erradicación o disminución del delito, en ese sentido, el abogado Francisco Bernate manifestó que los delincuentes no leen el Código Penal, cuando comenten sus delitos en sus planes no está que los descubran, agregando que mientras las personas creen que con el aumento de penas se van a reducir los delitos en realidad lo que observan es un aumento de los delitos, ofreciendo como solución es que la justicia opere. (LAUD Universidad Distrital Francisco José de Caldas, 2016)

Como afirma el abogado y politólogo José Fernando Flórez, si con aumento de penas, cadena perpetua y pena de muerte se acabara la criminalidad, la solución definitiva al problema sería fácil: bastaría con cambiar algunas palabras en el Código Penal. Pero el desafío real es la impunidad, la ineficacia del sistema penal para procesar a los ofensores y aplicar las penas existentes, que ya son bastante drásticas. (El Tiempo, 2016)

De hecho, fuentes estatales han subrayado el hecho, cierto que implica la notable disminución que en los últimos años ha presentado el delito de secuestro, destacando entre otras razones para esta disminución, la mutación de este por delitos como la extorsión, minería criminal y narcotráfico los cuales les proporcionan a las organizaciones criminales réditos importantes evitando los riesgos e implicaciones jurídicas que el secuestro implica, el alto nivel de compromiso y efectividad operacional de estas unidades especiales creadas en la lucha antisecuestro (GAULA), sin que se haga mención a los efectos que puedan derivarse de la aplicación de la ley expedida sobre secuestro y los efectos prácticos que esta pudiere haber tenido en la reducción del fenómeno, 
por lo cual se considera necesario hacer un análisis sobre la eficacia de esta legislación en la mengua de este flagelo.

\subsection{Política Criminal Del Estado Colombiano}

A lo largo de su historia Colombia se ha visto afectada por un dilatado contexto de violencia proveniente no solamente del conflicto armado con los grupos subversivos, de poderosas organizaciones de narcotráfico, y además de la percepción de inseguridad generada por el alto índice de delincuencia común que día a día afecta de manera notable la seguridad de los ciudadanos, que ven como son víctimas de la intimidación que genera esta transgresión, por lo que en la mayoría de las ocasiones demanda del Estado acciones eficaces tendientes a la prevención y eliminación del delito, a la sanción de sus autores y a la indemnización a que tendrían derecho dadas las afectaciones de que han sido objeto.

No obstante, han sido insuficientes los esfuerzos del Estado tendientes a implementar una estrategia encaminada a hacerle frente a conductas consideradas reprochables o causantes de perjuicio social, y que tenga como propósito garantizar la defensa de los intereses del propio Estado y de los derechos de los asociados que residen en el territorio nacional. Sobre tal punto, el Gobierno nacional reconoció en 2011 que el país carece de la política criminal y dando respuesta a esta preocupación resolvió organizar la Comisión Asesora de Política Criminal del Estado Colombiano, encargada de diseñar la construcción de una política criminal desde una perspectiva de derechos, que proteja tanto los derechos de las víctimas, como los de los autores de las conductas lesivas del ordenamiento penal. (Política Criminal del estado Colombiano, 2017) 
Análisis Socio Jurídico del delito de secuestro en Colombia a partir de 1970

Como se ha visto el legislador Colombiano ha apostado por un endurecimiento de las penas como instrumento de la política criminal, tal como puede observar en las exposiciones de motivos de las leyes, lo que permite trazar una línea político criminal basada en la pena como principal herramienta de prevención. En particular, ello se puede advertir como se he venido mencionando en la expedición de las leyes 40 de 1993, 733 de 2002, 1121 de 2006 entre otras cuto común denominador es el aumento de penas y supresión de subrogados con el objetivo que quien resulte condenado por un delito de secuestro sea aislado por una mayor cantidad de tiempo al estar privado de la libertad en un centro carcelario con la finalidad de que no vuelva a delinquir.

La Corte Constitucional con el fin de delimitar y ubicar los alcances del concepto constitucional en materia de política criminal en los siguientes términos define los bienes jurídicos que se deben proteger a través del orden jurídico penal, mediante:

"La tipificación de las principales hipótesis de comportamiento, que ameritan reproche y sanción punitiva sobre las principales libertades del sujeto que incurre en ellas". (Corte Constitucional, Sentencia C-599 de 1992, M.P. Fabio Morón Díaz). Establece "el aumento punitivo (...) coherente con la gravedad de la conducta delictiva, en función del interés tutelado" (Corte Constitucional, Sentencia C-127 de 1993, M.P. Alejandro Martínez Caballero). Determina "penas clasificándolas en principales y accesorias" (Corte Constitucional, Sentencia C-207 de 1993, M.P. Carlos Gaviria Díaz). El legislador establece los tipos penales; señala, en abstracto, conductas que, dentro de la política criminal del Estado y previa evaluación en torno a las necesidades de justicia imperantes en el seno de la sociedad, merecen castigo según el criterio de aquel" (Corte Constitucional, Sentencia C-626 de 1996, M.P. José Gregorio Hernández Galindo). Frente a las conductas que afectan un determinado bien jurídico cuya protección se ha considerado necesaria: 
Análisis Socio Jurídico del delito de secuestro en Colombia a partir de 1970

La política criminal del Estado puede variar, bien en el sentido de disminuir las penas o de suprimir delitos, ya en el de hacerlas más severas, o en el de consagrar figuras delictivas nuevas, según las variaciones que se van presentando en el seno de la sociedad, tanto en lo relativo a las conductas que la ofenden, como en lo referente a la magnitud del perjuicio que causan, no menos que en la evolución de los principios y valores imperantes dentro del conglomerado. (Corte Constitucional, Sentencia C-292 de 1997, M.P. José Gregorio Hernández Galindo)

Establece criterios de mitigación y humanización de la sanción punitiva, mediante el establecimiento de subrogados penales.

En el marco del Estado Social de Derecho, la pena, como instrumento adecuado para servir a los fines de prevención, retribución y resocialización, debe ser necesaria, útil y proporcionada; esto significa que si los mismos fines pueden lograrse por otros medios sancionatorios, debe preferirse el menos severo (pues el más restrictivo dejaría de ser necesario y útil), en aras de garantizar la dignidad del condenado. (Corte Constitucional, Sentencia C-679 de 1998, M.P. Carlos Gaviria Díaz)

Adicionalmente, la Corte ha señalado que la política criminal se articula, entre otros instrumentos, en normas penales:

La legislación penal es manifestación concreta de la política criminal del Estado. La decisión política que determina los objetivos del sistema penal y la adecuada aplicación de los medios legales para luchar contra el crimen y alcanzar los mejores resultados, se plasma en el texto de la ley penal. En este sentido, la norma penal, una vez promulgada, se independiza de la decisión política que le da origen, conservando 
Análisis Socio Jurídico del delito de secuestro en Colombia a partir de 1970

la finalidad buscada por su redactor en el elemento teleológico de la norma. (Corte

Constitucional, Sentencia C-504 de 1993, M.P. Eduardo Cifuentes Muñoz)

Como se ha mostrado, el Estado Colombiano ha advertido la necesidad de diseñar y construir una política criminal nacional, lo que además de ser una legitima preocupación interna se constituye en el cumplimiento a un requerimiento que se ha venido haciendo por parte de organizaciones internacionales como las Naciones Unidas que ha instado a los gobiernos que se lleven a cabo los necesarios esfuerzos para establecer sobre tal base, una justicia penal teniendo en cuenta factores políticos, económicos, culturales, sociales y otros a fin de establecer una justicia penal basada en los principios de una justicia social. (Naciones Unidas, 2013). En esta tarea se deberán observar, tal como lo reconoce el gobierno colombiano, aspectos desarrollados por la Corte Constitucional, en la sentencia C-646 de 2001, M.P. Manuel José Cepeda Espinosa, por tal razón en el diseño de este instrumento se deberán tener en cuenta gran variedad de temas que confluyen, como lo son las situaciones de orden social al interactuar con la comunidad en la solución de los diferentes problemas asociados a la comisión de un delito, de orden jurídico, como cuando se reforman las normas penales, de orden económico, como cuando se crean incentivos para estimular un determinado comportamiento o desincentivos para incrementarles los costos a quienes realicen conductas reprochables, de orden cultural, como cuando se adoptan campañas publicitarias por los medios de comunicación masiva para generar conciencia sobre las bondades o consecuencias nocivas de un determinado comportamiento que causa un grave perjuicio social, de orden administrativas, como cuando se aumentan las medidas de seguridad carcelaria e incluso pueden ser tecnológicas, como cuando se decide emplear de manera sistemática un nuevo descubrimiento científico para obtener la prueba de un hecho constitutivo de una conducta típica. (Política Criminal del Estado Colombiano, 2017) 
Análisis Socio Jurídico del delito de secuestro en Colombia a partir de 1970

En efecto, este debería ser el faro en nuestro ordenamiento legal en lo que a política criminal se refiere, un modelo en donde el Estado (legislador, aparato judicial, autoridades de policía) estuvieran en consonancia con el fin de seguir un mismo derrotero consistente en descubrir las causas del fenómeno criminal y encaminar de manera organizada las acciones del Estado tendientes a buscar e implementar estrategias con el fin de ofrecer soluciones eficaces a las numerosos problemas de fondo y de forma que se generan con ocasión a la ocurrencia de este acontecer delictivo, así como la confección de criterios éticos, económicos, políticos y sociales que servirán como marco de ubicación en la lucha contra el delito sus causas y efectos. No obstante, a nuestra política criminal se le hacen muchas críticas, ya que más que acciones organizadas y coherentes se han desplegado de manera coyuntural, influenciadas de la llamada "politiquería" que en busca de ganar réditos reacciona de manera desacertada, generando consecuencias nefastas al aparato judicial.

Dentro de estas críticas, se pueden citar la realizada por el CNMH cuando asegura que el vaivén de la legislación en materia de secuestro derivado de las diversas coyunturas políticas, ha ocasionado que el desarrollo normativo e institucional no haya sido sistemático e incorporado en el marco de una política criminal contra el secuestro integral, sino que por el contrario, obedece a políticas de seguridad nacional que han mimetizado a autores como las redes criminales y, por ende, han invisibilizado a numerosas víctimas. En su embate al diseño de esta estrategia estatal, el CNMH asevera que la normatividad para el desarrollo institucional ha sido dispersa y desarticulada, siendo elementos características de esta acción preventiva del estado el aumento de penas y el fortalecimiento de la capacidad de respuesta de la fuerza pública han sido elementos característicos de la acción preventiva del Estado, afirmando que: 
Análisis Socio Jurídico del delito de secuestro en Colombia a partir de 1970

En Colombia, las normativas obedecen a la lógica de la coyuntura y son concebidas bajo la presión y no a partir de la reflexión sobre el fenómeno. Por ejemplo, ante la explosión del secuestro durante el período de Masificación (1996-2000), el delito pasó de tener una pena de prisión de 15 a 25 años - vigente desde 1988 - a una de 25 a 40 años en 1993 y de 16 a 50 años a partir del 2004. En este punto, llama la atención que antes del 2004 - en los inicios de la etapa de Contención (2001-2005) - las penas impuestas eran de 10 a 28 años. (Centro Nacional de Memoria Histórica, 2013, p. 145) Tal situación anómala ha sido advertida por la Comisión Asesora de Política Criminal, que en el informe final del Diagnóstico y propuesta de lineamientos de política criminal para el Estado colombiano realizado en junio de 2012, luego de realizar un examen de las medidas de política criminal en Colombia en las últimas décadas muestra que carecemos de una política criminal consistente y de largo plazo, fundada empíricamente y enmarcada constitucionalmente. Por el contrario, el informe destaca algunos rasgos negativos por los que la política criminal en Colombia se ha caracterizado, cuáles son los de ser una política criminal reactiva, sin adecuada fundamentación empírica, con incoherencias y falta de perspectiva clara de derechos humanos. (Comisión Asesora de Política Criminal, Ministerio de Justicia, 2012, p, 25) El informe en cita, subraya que muchas decisiones de política criminal han sido esencialmente reactivas y sin fundamentos empíricos sólidos, muchas de estas medidas se han adoptado apresuradamente respondiendo a fenómenos de opinión pública o a los deseos de los gobiernos de mostrar que se está haciendo algo frente a la criminalidad o frente a hechos graves de crueldad o violencia, pero muy raramente estas decisiones se han basado en estudios empíricos sólidos que muestren la utilidad 
Análisis Socio Jurídico del delito de secuestro en Colombia a partir de 1970

de, por ejemplo, recurrir al aumento (o disminución) de una pena, o a la criminalización de un cierto comportamiento. (Comisión Asesora de Política Criminal, Ministerio de Justicia, 2012, p, 25)

De otra parte, estas decisiones han generado impacto negativo por cuanto se han realizado sin evaluar su posible impacto empírico, ya sea sobre la carga que la criminalización de un comportamiento implica para la labor de la Fiscalía y los jueces, o sobre el sistema carcelario, en la medida en que los aumentos precipitados de penas, o las restricciones de las posibilidades de libertad provisional, aumentan tendencialmente el hacinamiento carcelario, sin que se tomen decisiones claras para prevenirlo. (Comisión Asesora de Política Criminal, Ministerio de Justicia, 2012, p, 26)

Por lo anterior se sugiere por parte de la Comisión Asesora para corregir estas fallas, que una política criminal apropiada no sólo debe estar enmarcada normativamente y respetar en particular los principios de ultima ratio y no discriminación, como se ha desarrollado anteriormente sino que debe también ser una política adecuada en términos de racionalidad instrumental, propendiendo por la racionalización del sistema penal, ocupándose, por ejemplo, de la diferenciación de procedimientos para las llamadas pequeñas causas; la reglamentación del principio de oportunidad; la coherencia de los fines de la pena con los medios disponibles para su cumplimiento; la revisión de la legislación para asegurar su compatibilidad con las normas constitucionales y las condiciones sociales, etc. Por ello la política criminal debe entonces siempre contemplarse desde dos perspectivas: la primera como la política desarrollada por el Estado referente a las medidas, estrategias y acciones encargadas 
Análisis Socio Jurídico del delito de secuestro en Colombia a partir de 1970

de la prevención y represión del fenómeno criminal, y la segunda como el conjunto de conocimientos respecto de dichas medidas, estrategias y acciones implementadas por el Estado. (Comisión Asesora de Política Criminal, Ministerio de Justicia, 2012, p.

\subsection{Análisis Criminológico Y Política Criminal}

El análisis criminológico debe ir de la mano de la política criminal; corresponde a la criminología coordinar los saberes sectoriales (biológicos, psicológicos y sociológicos) sobre el crimen, integrando en modelos complejos diferenciadores y pluridimensionales la experiencia científica acumulada en los respectivos ámbitos y parcelas por los especialistas sin exclusiones ni monopolios que rompan la unidad del saber científico. En efecto en las teorías modernas se enfatiza en que al ser la criminología una ciencia interdisciplinaria, se auxilia de otras ciencias tales como la biología, la psicología, la sociología, el derecho penal, el derecho procesal penal y dentro de estos el estudio de la política criminal como conjunto de decisiones tomadas por el Estado, tendientes a configurar una serie de medidas de forma estratégica para prevenir y sancionar al delito. (García, 1989, p. 90)

Dentro de ellas emerge como función de política criminal del estado, la función preventiva de la sanción penal, dentro de la cual, en el contexto de la criminología moderna, caracterizada por los rasgos de un Estado Social y Democrático de Derecho, el fenómeno delictivo se asume de manera distinta. Se aborda como un problema social. En este modelo el castigo al infractor no agota las expectativas que el suceso delictivo desencadena. Importa más la prevención, la anticipación al fenómeno delictivo que la represión. Resulta relevante reparar el daño causado a la víctima y ofrecerle alternativas de socialización al delincuente. Bajo esta última perspectiva, la 
Análisis Socio Jurídico del delito de secuestro en Colombia a partir de 1970

prevención se ha consolidado de manera importante en la construcción de la política criminal en los Estados contemporáneos. No obstante, la prevención debe contextualizarse, pues de lo contrario existe el riesgo de generar un tópico vacío de contenido. (García, 1989, p. 90)

Desde la criminología, la prevención eficaz del delito es otro de sus objetivos prioritarios ya que no pretende suministrar información a los poderes públicos sobre aquél, para castigar el delito más y mejor, sino que pone a disposición su conocimiento científico del crimen, de su génesis, dinámica y variables más significativas, con el fin de propiciar una intervención meditada y selectiva capaz de anticiparse al mismo, de prevenirlo, neutralizando con programas y estrategias adecuadas sus raíces. Ello naturalmente se trata de una intervención eficaz, no de una intervención penal, ya que esta última, por su elevado coste social y nocivos efectos, debe ser siempre subsidiaria, de acuerdo con el principio de intervención mínima. (García, 1989, p. 91)

Tradicionalmente se había depositado demasiada confianza en el Derecho Penal utilizándose la amenaza del castigo como efecto disuasorio, en la que la prevención del delito se hacía a través de la pena. Sin embargo en la moderna Criminología, se reserva la pena a supuestos de estricta necesidad, en tanto una intervención de naturaleza penal es siempre traumática y negativa dado el elevado costo social. En ese orden de ideas, la pena se considera en algún caso imprescindible pero no es una estrategia racional para resolver conflictos sociales, por el contrario no soluciona nada. En ese orden de ideas, investigaciones citadas por García-Pablos sobre la efectividad del castigo, demuestran que el denominado "mecanismo disuasorio" es mucho más complejo de lo que se suponía: la mayor o menor eficacia contra motivadora o disuasoria de la pena no depende sólo -ni fundamentalmente- de su severidad, sino de otras muchas variables: y sobre todo, de cómo son percibidas y valoradas por el infractor potencial. Así, por ejemplo: la prontitud con que se imponga el castigo (inmediación estímulo/respuesta); el grado de 
Análisis Socio Jurídico del delito de secuestro en Colombia a partir de 1970

probabilidad de que efectivamente se imponga (falibilidad y percepción del riesgo); gravedad y contenido real del castigo (versus: rigor nominal); ponderación subjetiva de otras consecuencias inmediatas anteriores al eventual cumplimiento del castigo (vg. detención y privación provisional de libertad y otros derechos), respaldo informal que, en su caso, pueda recibir la conducta desviada -o el infractor- y capacidad de redefinir la misma; clase de delito de que se trate (criminalidad instrumental o expresiva); mayor o menor condicionamiento del infractor, etc. (García, 1989, p. 21)

En consecuencia, para el citado autor no cabe incrementar progresivamente la eficacia disuasoria de la pena aumentando, sin más, su rigor nominal; ni siquiera, recabando un mayor rendimiento y efectividad del sistema legal. Lo primero, atemoriza, no intimida. Lo segundo, multiplica el número de penados a corto plazo, pero no es una estrategia válida a medio ni a largo alcance. Porque, entre otras razones, la eficaz prevención del crimen es un problema de todos, y no sólo del sistema legal y sus agentes. Por el contrario cabe prevenir el delito no sólo contra motivando al infractor potencial con la amenaza del castigo (contra estímulo psicológico), sino de otros muchos modos, con programas que incidan en diversos componentes del selectivo fenómeno criminal: el espacio físico, las condiciones ambientales, el clima social, los colectivos de víctimas potenciales, la propia población penada, etc. Por ejemplo: neutralizando las variables espaciales y ambientales más significativas de aquél (programas de base ecológica, arquitectónico- urbanística, territorial); mejorando las condiciones de vida de los estratos sociales más deprimidos con las correspondientes prestaciones (vg. programas de lucha contra la pobreza); informando, concienciando y asistiendo a aquellos grupos y colectivos con mayor riesgo de victimización (programas de prevención de víctimas potenciales); procurando la reinserción social efectiva de los ex penados, una vez cumplidas las condenas, a fin de evitar la reincidencia de los mismos; 
Análisis Socio Jurídico del delito de secuestro en Colombia a partir de 1970

paliando, en la medida de lo posible, el magisterio criminógeno de ciertos valores sociales (oficiales o subterráneos), cuya lectura o percepción por el ciudadano medio genera actitudes delictivas, etc. (García, 1989, p. 92)

Ahora en el siglo XXI, la investigación científica, sobre todo en el Reino Unido y Estados Unidos, ha proporcionado pruebas recientes y convincentes de que el crimen y la violencia se reducen efectivamente y de manera rentable al invertir en niños y jóvenes residentes en aquellos lugares problemáticos donde se concentra la mayoría de las denuncias y llamadas de asistencia policial. Esto también demuestra que se necesitan estrategias integrales para detener la violencia armada, prevenir la violencia de género desde las escuelas y hacer cumplir las normas de tránsito correctamente. (Waller, 2014, p. 2)

Lo anterior, va en abierta contraposición con las decisiones adoptadas por el congreso Colombiano que ha apostado por un endurecimiento de las penas como instrumento de la política criminal, trazando una línea legislativa basada en la pena como principal herramienta de prevención, cumpliendo la mayoría de las veces a un discurso dado por el Ejecutivo tornado estas decisiones en leyes con contenido netamente político. Por ello, aunque pueda considerarse utópico, se espera del legislador que acoja estos argumentos científicos de la criminología moderna como instrumentos del Derecho Penal, que a través de la política Criminal puedan influir de manera favorable en la toma de decisiones sobre la materia, enfocándose más en aspectos como la prevención eficaz, la política social y la política de seguridad social proactiva como factores de disuasión hacia el delito. 
Análisis Socio Jurídico del delito de secuestro en Colombia a partir de 1970

\subsection{El populismo punitivo como posible factor en el incremento de penas}

El informe de la comisión asesora ha sugerido que el desarrollo de la política criminal no se base exclusiva ni fundamentalmente en la reacción inmediata a los actos criminales o a las demandas de seguridad ciudadana, sino en la adecuada planeación de respuestas a estos fenómenos, de conformidad con las evidencias empíricas y los fines del Estado de respetar y garantizar los derechos humanos, asegurar la convivencia dentro de un orden social justo, y preservar las condiciones necesarias para el ejercicio de las libertades públicas. (Comisión Asesora de Política Criminal, Ministerio de Justicia, 2012, p. 77)

Sin embargo, como se ha visto el desarrollo legislativo en el tema de secuestro, ha obedecido a coyunturas políticas que responden a políticas de seguridad nacional tomadas como reacción a la presión de la ciudadanía y al aumento de casos de mayor impacto, que traen como contestación del Estado el aumento de penas y el fortalecimiento de la capacidad de respuesta de la fuerza pública como elementos característicos de la acción preventiva del Estado. Ante ello se afirma que, en Colombia, las normativas obedecen a la lógica de la coyuntura y son concebidas bajo la presión y no a partir de la reflexión. Esta tradición legislativa de aumentar las penas, como instrumento orientado a agravar los costos por la comisión del delito, es la respuesta a eventos y circunstancias de mayor impacto en el escenario público, a giros y saltos a lo largo de este tiempo o al denominado populismo punitivo. (Centro Nacional de Memoria Histórica, 2013, p. 145)

Esta reacción Estatal se traduce en los proyectos de ley presentados por el gobierno o por el propio legislativo, tendientes en su totalidad a elevar las penas para punibles entre otros el de 
Análisis Socio Jurídico del delito de secuestro en Colombia a partir de 1970

secuestro, aumentar las circunstancias de agravación punitiva para este punible, excluir los subrogados y beneficios penales, prohibir el otorgamiento de amnistías e indultos en estos casos, a fin de hacer más severas sus consecuencias, en la mayoría de las ocasiones sin atender razones coherentes de política criminal.

Sobre el tema la sala penal de la Honorable Corte Suprema de Justicia, ha señalado que estas iniciativas legislativas denotan un desconocimiento de la realidad y dejan ver una absoluta falta de consistencia en la política criminal caracterizada por ser reactiva; carente de fundamentación empírica; incoherente; alejada de una perspectiva de derechos humanos; tendiente al endurecimiento de penas; poco reflexiva frente a los desafíos del contexto colombiano y subordinada a la política de seguridad. Destaca la Sala penal que la restricción de las posibilidades de aplicación de mecanismos de justicia premial han sido producto de un exacerbado populismo punitivo, y lejos de avanzar en el afianzamiento de una pronta, cumplida y adecuada justicia, están perjudicando la funcionalidad del sistema y consolidando su inoperancia.

En consecuencia, la Corte reitera su llamado de atención a las instancias legislativas y gubernativas competentes, a fin de que se consolide una verdadera política criminal en Colombia guiada por las pautas que trae la Constitución Nacional y las aplicadas con ocasión del Acto legislativo $\mathrm{N}^{\circ} 03$ de 2002, buscando lograr coherencia, consistencia y permanencia en los lineamientos para el tratamiento de los fenómenos delictivos, sin desconocer que la fijación de las penas debe responder a criterios de proporcionalidad y que el sistema penal ha de articular con fina precisión las medidas penales sustanciales con los efectos que, a través del proceso, pretende materializar el Estado 
Análisis Socio Jurídico del delito de secuestro en Colombia a partir de 1970

social y democrático de derecho. (Corte Suprema de Justicia, Sala de Casación Penal, 2013 Rad. 33254, M.P. José Leónidas Bustos Martínez)

Sobre estas motivaciones legislativas y sus consecuencias, ya en el año 2013 el entonces ministro de justicia Gómez Méndez, destacó en un Congreso Internacional de Política Criminal y Libertad realizado en la Universidad Externado de Colombia que llegaba el momento de hacer una evaluación: primero, sobre el objetivo de agilizar el procedimiento penal, que creo, salvo a los casos de flagrancia, eso no se ha logrado con relación a la legislación anterior. Y segundo, hacer efectivo el principio de que la privación de la libertad sea lo excepcional, y eso no está pasando. Todavía tenemos un 35 por ciento de personas que están en detención preventiva. Agregando que el país hemos vivido una especie de esquizofrenia institucional que se refleja en el hecho de que la normatividad va de un lado y la realidad de otro. Destacando contradicciones e incoherencias como la Ley 40 de 1993, llamada la 'Ley Pachito', con la que se aumentaron casi a 60 años las penas de secuestro, Ley de iniciativa popular que impulsó el ex vicepresidente Francisco Santos, y después en el Gobierno del que hizo parte, se permitió que se aplicaran penas de 8 años para esos delitos con la puesta en marcha de la Ley de Justicia y Paz. Hay más ejemplos y con ellos quiero significar los bandazos que en materia de penas da el Estado colombiano, expresó el ministro. (Ministerio de Justicia, 2013)

Para el año 2015, el ministro de Justicia Yesid Reyes Alvarado, ratificó como uno de los propósitos de su gestión trabajar por frenar el populismo punitivo, afirmando que en nuestro país se tiende a solucionar los conflictos sociales mediante la utilización directa del sistema penal, renunciando a explorar formas distintas de conseguirlo; por ello es evidente que ante cualquier 
Análisis Socio Jurídico del delito de secuestro en Colombia a partir de 1970

dificultad en lo que debe ser la convivencia pacífica de los habitantes del territorio nacional, en lo primero que se piensa es en tipificar nuevas conductas como punibles, aumentar penas o reducir o eliminar beneficios para las personas procesadas y condenadas.

En concepto del citado ministro, el populismo punitivo se genera en buena parte en el Congreso de la República, y ante ello sería prudente que se capacite en la materia a quienes crean las leyes, a fin de que se comprenda que el Derecho Penal y la cárcel no deben ser la solución para todos los problemas del país. No obstante, se puede ver que en ocasiones es más fuerte la necesidad o el deseo de congraciarse con los electores y la comunidad en general, por lo cual resultará necesaria una férrea posición del poder Ejecutivo para que se pueda apaciguar el populismo punitivo. (Ámbito Jurídico, Gil, 2015)

De la misma manera, se puede ratificar que el concepto de populismo punitivo no es algo novedoso, por el contrario son varios los doctrinantes que se han pronunciado sobre el tema, Roxin ha sido enfático en destacar que el populismo punitivo es una tendencia errada que existe no solo en Colombia sino en todos los países, incluida Europa, añadiendo que aumentar o dar una pena no cambia en nada la existencia de crímenes y por eso la medida más eficaz contra la criminalidad es tratar de cambiar los orígenes y las causas de estos comportamientos. (El Tiempo, 2017)

Para Eduardo Jorge Prats es la estrategia desplegada por actores políticos y funcionarios del sistema penal, encaminada, aparentemente, a remediar los problemas que se derivan del crimen y la inseguridad, pero que en el fondo implica una alianza demagógica para crear en la conciencia ciudadana la necesidad de aplicar medidas extremas de "mano dura" y "tolerancia cero" contra los infractores, aun en delitos de 
Análisis Socio Jurídico del delito de secuestro en Colombia a partir de 1970

menor impacto, a sabiendas de que son respuestas eufemísticas, viscerales, basadas en sondeos no confiables, que lejos de disminuir la tasa delincuencial, la incrementan de manera incontrolable.

Wanda Fernández león afirma que es el terrorismo judicial que amenaza al defensor que se opone a los desafueros; que intimida al fiscal que archiva o impetra preclusiones; que procesa disciplinaria y/o penalmente al juez constitucional que cumple a cabalidad su sagrada misión. Populismo es derecho penal del enemigo y al enemigo hay que inocuizarlo a cualquier precio, agregando que el populismo penal promueve, desde el Gobierno y el Parlamento -obviamente sin previos estudios de política criminal, pero con gran incidencia en el nivel político-electoral-, la expedición de leyes impróvidas, incongruentes, irracionales, para aumentar penas, crear delitos, reducir beneficios, privatizar la justicia y de contera, desestructurar el modelo procesal, soslayar derechos, menoscabar garantías y vulnerar el debido proceso acusatorio.

Iñaki Rivera director del Observatorio del Sistema Penal y los Derechos Humanos de la Universidad de Barcelona citado por Wanda Fernández León, asevera que: el impacto mediático del delito que conmociona al ciudadano es aprovechado en este contexto, para aparentar que se da respuesta a las justas reclamaciones de la sociedad, asediada por múltiples violencias. Es cuando aparecen los redentores, los vengadores de la justicia, vestidos de toga en los complejos judiciales escudriñando la verdad verdadera o, en los escenarios parlamentarios, enarbolando otro proyecto retrógrado de urgente aprobación. "Primero, hace falta infundir alarma social entre los 
Análisis Socio Jurídico del delito de secuestro en Colombia a partir de 1970

ciudadanos, meterles miedo y después, ya vendrán los diferentes actores a aportar soluciones represivas, que serán inmediatamente aceptadas por una población asustada de antemano. Se trata de tocar las fibras más sensibles de la población para producir un consenso social y aplicar las más represivas políticas en materias penal, judicial, penitenciaria y administrativa" (Ámbito Jurídico, 2012)

Por lo tanto de los resultados que se analizaran a continuación en lo que tiene que ver con el efecto real de las leyes expedidos en materia de secuestro, permiten colegir un objetivo distinto al de lograr efectos prácticos para la disminución o erradicación del secuestro, lo que se pretendía era dar gusto al sector de la sociedad afectado, que buscaba la satisfacción de sus intereses, citando a Michael Reed Hurtado investigador de la Corporación Punto de Vista podemos precisar esta idea cuando afirma:

Parte de la sociedad colombiana está enamorada con los discursos que prometen castigo. Estas personas no parecen interesarse mucho por la efectividad del castigo para lograr cosa alguna. Su encantamiento se queda con el pronunciamiento público contra el mal, como si esto logrará hacerlo desaparecer. El movimiento es poderoso porque ciertamente produce un sentimiento colectivo: nosotros los buenos estamos en contra de los malos y rechazamos el crimen. Un ejercicio simbólico que, si bien genera un sentimiento de solidaridad al nombrar el mal, también genera un vació en respuestas públicas en la medida en que no exige respuesta distinta al castigo frente a problemas sociales apremiantes. Nos quedamos con lo inmediato: más castigo, como símbolo. De esta manera, se utiliza la función simbólica del derecho penal; es decir, se producen normas para aparentar que se hace algo contra el crimen, aunque su eficacia es sólo preformativa. (Reed, 2012) 
Análisis Socio Jurídico del delito de secuestro en Colombia a partir de 1970

La escuela judicial Rodrigo Lara Bonillav en el año 2010 entre otras reflexiones sobre la política criminal colombiana reveló serios problemas de coherencia en la asignación de penas, entre la gravedad y peligrosidad de la conducta y la sanción a imponer, detectó la influencia de determinados grupos de interés sobre la labor legislativa, a grado tal que según su capacidad así será la magnitud de la sanción a imponer, y la desproporción entre tipo, hecho delictivo y sanción o pena lo que demuestra no sólo ausencia de política criminal, sino también carencia de criterios claros en materia de rehabilitación, evidenciando con ello que en nuestro Estado democrático, las soluciones suelen diseñarse ex post y no ex ante, es decir, no se estructura una política criminal preventiva, sino sólo represiva. (Consejo Superior de la Judicatura. Sala administrativa. Escuela Judicial "Rodrigo Lara Bonilla", 2010)

Para sintetizar, se puede afirmar que la legislación expedida en Colombia tendiente a prevenir y erradicar el delito de secuestro, así como a sancionar a sus autores y a indemnizar a sus víctimas no ha obedecido al desarrollo de una política criminal coordinada y planificada, sustentada en el marco de un sistema penal con tendencia acusatoria acorde con los principios rectores y garantías procesales que ofrece un Estado social de Derecho, con sujeción de los fundamentos de la justicia, la legalidad y los límites del derecho de castigar, los derechos de los asociados y la resocialización de los delincuentes. Por el contrario, retomando lo dicho por el $\mathrm{CNMH}$, esta estrategia de lucha contra la delincuencia y en especial contra el secuestro, se ha caracterizado por ser coyuntural, incoherente, descontextualizada desde la realidad social, económica y política del momento, sin fundamento de orden empírico, carente de técnica legislativa y subordinada a la política de seguridad de los Gobiernos de turno que en las últimas décadas han definido políticas de seguridad y paz en el que los organismos de seguridad tienen prioridad. (Política Criminal del Estado Colombiano, 2017) 
Análisis Socio Jurídico del delito de secuestro en Colombia a partir de 1970

En efecto, esta carencia de política criminal y las falencias que se han presentado en su intento de implementación por parte del Estado Colombiano, explican de alguna manera el por qué la legislación expedida en ese contexto, no ha cumplido con su propósito de prevenir y erradicar el delito de secuestro, sino que la disminución en los índices de ocurrencia de casos se deben a factores sociales y políticos diferentes a la expedición de legislación. Es así como con las cifras analizadas a través de este estudio se ha venido demostrando que en la casi totalidad de los casos, se ha utilizado la legislación y específicamente el aumento de penas y exclusión de beneficios, como herramienta para contrarrestar los altos índices de criminalidad y de sus colaterales altos índices de impunidad, lo cual ha tenido efectos infructuosos tal como igualmente ha quedado expuesto.

Lo anterior permite prever que la principal política criminal implementada por el Estado Colombiano, consistente en el aumento de las penas por hechos coyunturales, es de naturaleza puramente represiva y con ello se convierte en un fenómeno distractor que no permite hacer un análisis de fondo debate de fondo sobre los reales factores que generan la impunidad. En consecuencia , esta herramienta no dará los resultados favorables que se esperan, si no se armoniza con otras estrategias de orden cultural, social, administrativo, económicas e incluso tecnológicas que puedan resultar útiles para la resolución de estos conflictos, que de suyo no solo son consecuencias de la guerra contra la subversión, sino que se presentan en el día a día, afectando directamente a la gran mayoría de los ciudadanos, como la inseguridad -y la percepción que se tiene de ella que a veces es mayor que la real-, la corrupción, la pobreza, la desintegración familiar, el desempleo, la falta de acceso a los sistemas de salud y educación, así como el creciente consumo de estupefacientes entre la población infantil y juvenil. 


\section{Conclusiones}

El principal objetivo de este trabajo consistió en realizar un análisis, esencialmente, socio jurídico sobre el fenómeno del secuestro en Colombia desde 1970 hasta 2010, desde un enfoque principalmente empírico. Esto con el propósito de abordar el fenómeno desde aristas, a saber: el secuestro en la historia de la humanidad, la definición etimológica y legal del secuestro, la definición dogmática, la historia del secuestro en Colombia, la legislación expedida en Colombia sobre el secuestro y su tipificación, las modalidades del secuestro en Colombia y la información cuantitativa sobre el fenómeno; finalmente, a partir de todo lo anterior, se realizaron un conjunto de reflexiones sobre algunos principios de la dogmática en el derecho penal.

Cada una de las dimensiones abordadas en esta investigación pretendían dar luces para contestar a una gran pregunta de investigación: ¿Qué factores explican la variación en el número de secuestros en el país desde 1970 hasta 2010? A continuación, se exponen de manera sucinta, las principales conclusiones frente a esta pregunta.

En primer lugar, los niveles de secuestros varían en Colombia en concordancia con la guerra. La dinámica de la violencia convirtió al secuestro en una actividad utilizada por todos los grupos inmersos dentro del conflicto armado. No obstante, su utilización como herramienta de presión política y forma de financiación fue mayor por parte de los grupos armados ilegales, especialmente, de las guerrillas. En consecuencia podemos advertir que a lo largo de la historia de nuestro país especialmente en los siglos XX y XXI, el delito de secuestro se ha convertido en una verdadera amenaza para toda la ciudadanía, tanto de forma individual como colectiva, teniendo consecuencia en la estabilidad socioeconómica de nuestro país, en efecto el Centro Nacional de Memoria Histórica ha documentado 39.058 casos de secuestro ocurridos entre los años de 1970 a 
Análisis Socio Jurídico del delito de secuestro en Colombia a partir de 1970

2010, siendo los más frecuentes aquellos que tuvieron motivaciones políticas y económicas. Como se dijo, las guerrillas han utilizado el secuestro como estrategia de presión política, particularmente en el marco de negociaciones de paz con el Gobierno, privando ilegalmente de la libertad a servidores del Estado puntualmente militares y policías, y posteriormente a políticos que tuvieran relevancia ante la sociedad y el propio gobierno Nacional, esto con el fin de publicitar un discurso político y presionar el llamado "canje" o "intercambio humanitario" que involucraría la liberación de estos y en contraprestación el Estado liberaría a guerrilleros detenidos en las cárceles Colombianas. En el transcurso de la primera década de este siglo, las guerrillas han iniciado con el gobierno Nacional del presidente Juan Manuel Santos, diálogos tendientes a lograr acuerdos de paz, lo cual ha reducido las cifras de ocurrencia de este delito, a tal punto que entre el año 2000 y el mes de enero del año 2017 se había reducido en un 94\%, ya que de 3.572 casos reportados en el año 2000, se disminuyó a 199 en 2016 y 190 en 2017. En la actualidad, la mayoría de los casos de secuestro que se cometen en nuestro país, se le atribuyen a la delincuencia común. En la medida que la guerra ha tomado nuevas dinámicas, el modus operandi de los actores involucrados en ella también han cambiado sus repertorios de violencia, entre ellos, el secuestro.

A pesar de que el fenómeno del secuestro en nuestro país se acentuó en la década de los años 80 y 90, se viene presentando desde la década de los 50 habiendo ocurrido el primer caso en Cali en el año de 1954, caracterizándose este delito por ser un chantaje o mecanismo de presión en el que los captores pretenden con la privación de la libertad de la persona obtener beneficios ya sean de carácter político o económico. Los réditos de carácter económico, son requeridos por grupos de delincuencia común y grupos subversivos como forma de financiación y en el orden político a mediados del siglo continuando con una práctica utilizada en los años 60 en Latinoamérica, en Colombia el secuestro ha sido utilizado por grupos subversivos como medio 
Análisis Socio Jurídico del delito de secuestro en Colombia a partir de 1970

de presión política, así como por grupos de narcotráfico y de paramilitares que buscaban chantajear al gobierno para que desistiera de la toma de medidas coercitivas en su contra, v. gr. extradición.

Ahora bien, para explicar la reducción del fenómeno de secuestro en Colombia, no es difícil advertir que en vigencia de las FARC como grupo guerrillero, en sus últimos años y ahora el ELN han mutado sus actividades de financiación, hacia otros ilícitos que generan mayores divisas tales como el narcotráfico, minería ilegal y la extorsión entre otros. Esto se explica por cuanto la comisión de estas actividades igualmente delictuales les generaba menor desgaste de su imagen política ante la sociedad, dadas la reacción legítima de la sociedad frente a este flagelo y al alto grado de animadversión en su contra, además de los costos económicos y logísticos que generaba para las guerrillas la práctica del secuestro.

En segundo lugar, la política criminal con respecto al secuestro ha sido un factor importante en la variación del fenómeno a lo largo del tiempo pero no el único. La reacción del Estado Colombiano ante la creciente oleada de secuestros que se padecía a finales de siglo XX e inicios del XXI, fue la de dictar leyes con una serie de códigos penales y reformas a estos, todas ellas con un objetivo fundamental cual era el de erradicar el delito de secuestro, utilizando para ello el aumento de las penas previstas, así como la eliminación de subrogados o beneficios para quienes incurrían en la práctica de este ilícito. A pesar de esos plausibles propósitos, la legislación no cumplió con los objetivos trazados de erradicar, prevenir la comisión del secuestro, si bien en algunos casos se disminuyó en otros se mantuvo igual o en el peor de los casos aumentó luego de la expedición de las normas, este en consecuencia no es el factor desencadenante de la disminución en las estadísticas. Por el contrario, el análisis de estas cifras permite advertir que situaciones de orden político y social como los diálogos de paz con las guerrillas, la acción del Estado a través de 
Análisis Socio Jurídico del delito de secuestro en Colombia a partir de 1970

los grupos de policía y Ejército Nacional, así como la desmovilización de grupos paramilitares constituyen una real causa de las bajas cifras de este tipo de trasgresión del código penal, ello por cuanto se ha reducido a una mínima expresión el porcentaje de secuestros cometidos por las FARC, ELN y grupos paramilitares que llegaron a ascender al $65 \%$ del total de casos cometidos en Colombia. En consecuencia, hay que decirlo claro: el secuestro no disminuye únicamente por los cambios en las leyes de aumento de penas o supresión de beneficios a los investigados y condenados, este es solo uno más de los factores desencadenantes de este resultado que obedece como se ha dicho a otros fenómenos sociales y políticos que si han sido verdaderamente las causas de la reducción de este flagelo que ha afectado en gran medida a nuestra sociedad.

Este modelo de lucha contra el secuestro implementado por el Estado, no ha obedecido al desarrollo de una política criminal coordinada y planificada, sustentada en el marco de un sistema penal con tendencia acusatoria acorde con los principios rectores y garantías procesales que ofrece un Estado social de Derecho, con sujeción de los fundamentos de la justicia, la legalidad y los límites del derecho de castigar, los derechos de los asociados y la resocialización de los delincuentes. Por el contrario, se ha distinguido por ser coyuntural, incoherente, descontextualizado desde la realidad social, económica y política del momento, sin fundamento de orden empírico, carente de técnica legislativa y subordinada a la política de seguridad de los Gobiernos de turno que en las últimas décadas han definido políticas de seguridad y paz en el que los organismos de seguridad tienen prioridad. Esta carencia de política criminal y las falencias que se han presentado en su intento de implementación por parte del Estado Colombiano, explican de alguna manera el por qué la legislación expedida en ese contexto no ha cumplido con su propósito de prevenir y erradicar el delito de secuestro, sino que la disminución en los índices de ocurrencia de casos se debe a factores sociales y políticos diferentes a la expedición de legislación 
Análisis Socio Jurídico del delito de secuestro en Colombia a partir de 1970

El aumento de penas como instrumento estatal para la prevención y erradicación del delito, tiene una esencia puramente represiva y con ello se convierte en un fenómeno distractor que no permite hacer un análisis de fondo sobre los reales factores que generan la impunidad. En consecuencia, esta herramienta no dará los resultados favorables que se esperan, si no se armoniza con otras estrategias de orden cultural, social, administrativo, económicas e incluso tecnológicas que puedan resultar útiles para la resolución de estos conflictos.

En tercer lugar, las movilizaciones ciudadanas y la presión internacional fueron determinantes en la variación del fenómeno. El secuestro como fenómeno no sólo afecta dramáticamente al secuestrado, sino también a su familia y a sus allegados, no obstante, en las décadas de los 80 y 90 principalmente, este flagelo coexistía en la sociedad colombiana siendo percibido a veces de forma indolente por ella. Posteriormente, se crearon por parte de víctimas de secuestro organizaciones que motivaron a la colectividad para movilizarse a través de manifestaciones realizadas en contra de sus autores más visibles: las guerrillas. Es de resaltar que esta animosidad generada por estos grupos subversivos ante la sociedad civil se constituiría en una de las causas que llevaría a la guerrilla de las FARC a abandonar la práctica del secuestro y a que en las negociaciones de paz llevadas a cabo a lo largo de este periodo, el tema los secuestrados se convirtieran en un recurso. Es importante resaltar que las movilizaciones sociales fueron determinantes para que los legisladores, en su afán por responder a las demandas de la sociedad, terminarán expidiendo legislación al respecto.

En cuarto lugar, la variación del fenómeno también obedece a la racionalidad de los actores involucrados. Es un hecho cierto que la desmovilización de los grupos paramilitares, 
Análisis Socio Jurídico del delito de secuestro en Colombia a partir de 1970

aunque posterior a ello han surgido los grupos armados pos desmovilización o BACRIM, puede evidenciar una tendencia de desescalamiento intenso, en la cual se redujeron ostensiblemente las estadísticas de casos de las masacres al igual que el secuestro y la desaparición forzada . En el mismo sentido se puede destacar los avances surgidos con ocasión a la realización de procesos de paz con las FARC y el ELN, dentro de los cuales se ha pactado con estas agrupaciones subversivas el cese de comisión de conductas delictuales (dentro de ellas el secuestro), la intención de reparación a las víctimas y el compromiso de no repetición.

En quinto lugar, el fenómeno del secuestro y la legislación creada en torno a él no es un fenómeno exclusivamente doméstico colombiano. El secuestro no es particular de una región o época determinada ya que este delito ha tenido vigencia desde los tiempos primitivos a nivel orbital, siendo utilizado en principio como forma de esclavitud, para fijar condiciones de guerra, como forma de sometimiento o comercio de personas, como forma de obtener un rescate exigiendo contraprestación económica. En la actualidad el secuestro de personas, en cualquier circunstancia e independientemente de su propósito, constituye un delito grave y una violación de la libertad individual que menoscaba los derechos humanos, por lo que los gobiernos nacionales y los organismos multilaterales, preocupados además por el aumento de la práctica del secuestro en varios países del mundo y por los efectos perjudiciales que este delito produce en las víctimas y sus familias, han decidido crear instrumentos para velar de manera efectiva por la garantía de los derechos humanos.

En términos generales se ha definido la acción de secuestro como el hecho de aprehender indebidamente a una persona para exigir dinero por su rescate o para otros fines, agregando que 
Análisis Socio Jurídico del delito de secuestro en Colombia a partir de 1970

en la Legislación Penal se suele definir ese delito con alcance más limitado que en la definición lingüística, ya que se configura por el hecho de que el secuestro se realice con el propósito, logrado o no, de obtener rescate, y de ahí que se haya incluido entre los delitos contra la propiedad y, dentro de ellos, entre los de extorsión. Pese a que en las diferentes legislaciones de países referentes en materia de secuestro, existe diversidad en la descripción de las conductas que se consideran constitutivas de este delito, tales como las de arrebatar, sustraer, retener, ocultar, encerrar, detener, exponer a otra persona a situación de desamparo, a esclavitud o servidumbre, privar de su libertad ilegítimamente; todas ellas coinciden de fondo en que se trata de una privación ilegal de la libertad de un individuo con fines delictivos y en contra de su voluntad. En el mismo sentido son coincidentes las legislaciones en establecer como causales de agravación aquellas relacionadas con el propósito de exigencia económica, el tiempo de duración del cautiverio, la edad de la víctima, entre otras.

Desde el punto de vista dogmático, podemos concluir que el tipo penal de secuestro simple tal como se encuentra descrito en la legislación Colombiana es un delito de aquellos llamados de resultado, de lesión, cuya conducta permanece mientras se lleve a cabo la retención, pluriofensivo, su autor es indeterminado al igual que el sujeto pasivo puede ser cualquier persona, la conducta consiste en arrebatar, sustraer, retener u ocultar a una persona afectando el bien jurídico de la libertad individual. Este delito es esencialmente doloso y la pena fijada oscila entre los 12 a 20 años de prisión y multa de 600 a 1000 salarios mínimos legales mensuales vigentes. El secuestro extorsivo tiene además de lo descrito en el inciso anterior para el secuestro simple, elementos normativos diversos tales como el propósito de exigir un provecho o utilidad, o con fines publicitarios o de carácter político, la pena fijada de 320 a 504 meses y multa de 2666.66 a 6000 salarios mínimos legales mensuales vigentes. Como circunstancias de agravación punitiva para el 
Análisis Socio Jurídico del delito de secuestro en Colombia a partir de 1970

secuestro extorsivo se establecen entre otros aquellas relacionadas con la edad o condición de la víctima, la condición del autor, cuando los medios que se empleen impliquen riesgo de muerte o peligro común, cuando se cometa con fines terroristas, cuando sobrevenga la muerte de la víctima. Todo esto hace que los grupos prefieran utilizar otras estrategias, como por ejemplo la extorsión, para que, en el caso de ser capturados, las penas sean más bajas.

Finalmente, los hallazgos de esta investigación abren un camino para la realización de investigaciones posteriores en las que se respondan los siguientes interrogantes:

1. ¿Existen estrategias útiles para erradicar el delito de secuestro?

2. ¿Existen estrategias para abordar la temática del secuestro y específicamente su prevención y erradicación, desde un punto de vista socio cultural?

3. ¿Tiene alguna relevancia la precaria situación económica de la sociedad colombiana en la comisión de conductas delictivas, en especial el secuestro?

4. ¿El sistema judicial colombiano, está acorde con los índices de comisión de delitos en el territorio?

5. ¿Es posible blindar al legislador de la influencia del populismo punitivo? 


\section{Referencias Bibliográficas}

Agudelo, D. (2000) El horror de lo incierto intervención psicológica con víctimas de secuestro. Psicología desde el Caribe. 6, 20-38.

Alcaldía Mayor de Bogotá (Decreto 1837 de 2002) Por el cual se declara el Estado de Conmoción Interior”. Diario oficial 44.877 del 11 de agosto de 2002. Disponible: http://www.alcaldiabogota.gov.co/sisjur/normas/Norma1.jsp?i=5522

Alto Comisionado para la Paz (2016) Acuerdo final para laterminación del conflicto y la construcción de una paz estable y duradera. Disponible: http://www.altocomisionadoparalapaz.gov.co/procesos-yconversaciones/Documentos\%20compartidos/24-11-2016NuevoAcuerdoFinal.pdf

Ámbito Jurídico (2012) Populismo punitivo. Disponible en: https://www.ambitojuridico.com/noticias/columnista-impreso/penal/populismo-punitivo Ámbito Jurídico (2015) ¿Cómo atacar el populismo punitivo? Gil, O. 21 de Enero del 2015. Disponible en: https://www.ambitojuridico.com/educacion-y-cultura/como-atacar-elpopulismo-punitivo

Arboleda, M. y Ruiz, J.A. (2002) Manual Derecho Penal. 3 edición editorial. Leyer 2002.

Ariza, D.F: (2014) La zona de distensión del Caguán: análisis de los Factores económicos, políticos y sociales a partir del Concepto de estado fallido. Universidad Colegio Mayor de Nuestra Señora del Rosario. Disponible http://repository.urosario.edu.co/bitstream/handle/10336/8347/10305603892014.pdf? sequence $=12$ 
Análisis Socio Jurídico del delito de secuestro en Colombia a partir de 1970

Asuntos Legales (2017) Colombia pasó de 3.500 secuestros por año a 205 en 2016. Disponible en: https://www.asuntoslegales.com.co/actualidad/colombia-paso-de-3500-secuestrospor-ano-a-205-en-2016-2473826

Asuntos Legales (2017) Disponible en: https://www.asuntoslegales.com.co/actualidad/ejercitode-liberacion-nacional-eln-ve-dificil-suspender-los-secuestros-pese-a-dialogo-de-paz2543720.

Bentham (1825) Teoría de las penas legales. 2 vols., Imprenta de J. Smith, París.

Bustamante, J.L. (2011) Disponible en: http://jbpenalgeneral.blogspot.com.co/2011/01/20-laculpabilidad.html

Bustos, J. (1991) Manual de Derecho Penal. Parte Especial. Editorial Ariel.

Bustos, J. (2012) Política criminal y Estado. Disponible en: https://es.scribd.com/document/85535554/Bustos-Juan-Politica-Criminal-y-

Estado?doc_id=85535554\&download=true\&order $=443650877$

Callamand, L. (1988) La libertad y el delito de secuestro. Pontificia Universidad Javeriana. Ciencias Jurídicas y socioeconómicas. Bogotá, Colombia.

Caracol (2011) Cronología del secuestro en Colombia. Disponible en: http://caracol.com.co/radio/2011/11/26/judicial/1322312520_584076.html

Caracol Radio (2008) Problemas de columna, gástricos, cardiacos y cerebrales le dejó el secuestro a Jorge Eduardo Gechem. Disponible en: http://caracol.com.co/radio/2008/02/29/nacional/1204267500_556532.html 
Análisis Socio Jurídico del delito de secuestro en Colombia a partir de 1970

Carrara, F. (1889) Programa Del Curso De Derecho Criminal Desarrollado En La Universidad De Piza. Traducido Por Octavio Béeche, Iberio Gallegos. Parte General. TOMO I. Tipografía Nacional. San José. Costa Rica.

Carrara, F. (1996) Programa del curso de derecho criminal. Ed. Depalma, Bs. As.

Carrara, F. (1996) Programa de derecho criminal parte especial. Vol. IV. Segunda Edición. Editorial Temis, Bogotá, Colombia.

Centro Nacional de Memoria Histórica (2013) Una sociedad secuestrada. Disponible en: http://www.centrodememoriahistorica.gov.co/descargas/informes2013/farc/guerrillapoblacion-civil.pdf

Cita, R. y Gonzáles, I. (2017) La proporcionalidad de las penas en la legislación penal colombiana. Ediciones Gustavo Ibáñez Carreño. Disponible en: http://www.politicacriminal.gov.co/Portals/0/documento/LaPropoPenLeCol.pdf?ver=201 7-03-29-110809-953

Cifras y conceptos (2010) Número de secuestros por autos. Disponible en: http://www.cifrasyconceptos.com/secuestro/secuestros_autor.php\#

Clutterbuck, R. (1979) Secuestro y rescate. Edición en español. Fondo de cultura económica. México, Madrid, Buenos Aires.

CNDH (2016) Racionalización de la pena de prisión. Pronunciamiento. Disponible en: http://www.cndh.org.mx/sites/all/doc/Informes/Especiales/Pronunciamiento_20160331.p df 
Análisis Socio Jurídico del delito de secuestro en Colombia a partir de 1970

Código Federal Penal (2014) Disponible https://www.iberred.org/sites/default/files/codigo_penal_federal_de_los_estados_unidos_ mexicanos.pdf

Código Penal de Alemania (1871) Ein Service der juris GmbH - www.juris.de - Seite 1. Disponible en: http://perso.unifr.ch/derechopenal/assets/files/legislacion/1_20080616_01.pdf

Código Penal de Brasil (1998) Disponible en: https://www.iberred.org/sites/default/files/codigopenal-brasil.pdf

Código Penal Colombiano Artículo 3 y 4.

Código Penal de Chile (1874) Disponible en: https://www.iberred.org/sites/default/files/codigopenal-de-chile.pdf

Código Penal de Guatemala (1973) Disponible en: https://www.iberred.org/sites/default/files/codigo-penal-de-guatemala.pdf

Código Penal de Italia (1930) Disponible en: http://perso.unifr.ch/derechopenal/assets/files/legislacion/1_20080616_59.pdf

Código Penal de Puerto Rico (2012) Ley Núm. 146 de 30 de julio de 2012. Disponible en: http://www.lexjuris.com/lexlex/Leyes2012/CodigoPenal2012.pdf

Código Penal de Venezuela (2000) Disponible en: http://www.oas.org/juridico/spanish/mesicic3_ven_anexo6.pdf

Código Penal y Legislación Complementaria (2016) Disponible en: https://www.iberred.org/sites/default/files/codigo-penal-en-vigor.pdf 
Análisis Socio Jurídico del delito de secuestro en Colombia a partir de 1970

Colombiacheck (2018) Es verdad que las Frac aún tienen en su poder a 300 secuestrados. Disponible en: https://colombiacheck.com/chequeos/es-verdad-que-las-farc-aun-tienenen-su-poder-a-300-secuestrados.htm.

Comisión Asesora de Política Criminal (2012) Diagnóstico y propuesta de lineamientos de política criminal para el Estado colombiano. Disponible en: https://www.minjusticia.gov.co/Portals/0/INFO\%20POLI\%20CRIMINAL_FINAL23NO V.pdf

Comisión de Derechos humanos (1997) Disponible en: https://www.google.com.co/search?q=resoluci\%C3\%B3n+1997\%2F50\&oq=resoluci\%C 3\%B3n+1997\%2F50\&aqs=chrome..69i57.1253j0j8\&sourceid=chrome \&ie=UTF-8

Comité Internacional de la Cruz Roja (2012) Los Convenios de Ginebra del 12 de Agosto de 1949. Disponible en: https://www.icrc.org/spa/assets/files/publications/convenios-gva-esp2012.pdf

Consejo de Bogotá (2004) Acuerdo 124 de 2004. Por el cual se otorgan unas Exenciones Tributarias a las Personas Víctimas de Secuestro y Desaparición Forzada, se reconoce el Tratamiento que opera en el Distrito Capital para el cumplimiento de las Obligaciones Tributarias a su cargo y se regula el acceso al Sistema de Seguridad Social en Salud y Educación para sus Familias. Disponible en: http://www.alcaldiabogota.gov.co/sisjur/normas/Norma1.jsp?i=14121

Consejo Superior de la Judicatura. Sala administrativa. Escuela Judicial "Rodrigo Lara Bonilla" (2010) Política Criminal del Estado Colombiano. Disponible en: http://ejrlb.net/biblioteca2011/content/pdf/a16/11.pdf 
Análisis Socio Jurídico del delito de secuestro en Colombia a partir de 1970

Congreso de la República de Colombia (2000) Ley 599 de 2000. Diario Oficial No. 44.097 de 24 de julio del 2000. Disponible en: https://docs.supersalud.gov.co/PortalWeb/Juridica/Leyes/L0599_00.pdf

Congreso de la República de Colombia (2002) Ley 733 de 2002. Por medio de la cual se dictan medidas tendientes a erradicar los delitos de secuestro, terrorismo y extorsión, y se expiden otras disposiciones. Diario Oficial No 44.693, de 31 de enero de 2002. Disponible en: http://www.dmsjuridica.com/CODIGOS/LEGISLACION/LEYES/L0733002.htm

Congreso de la República de Colombia (2005) Ley 986 de 2005. Por medio de la cual se adoptan medidas de protección a las víctimas del secuestro y sus familias, y se dictan otras disposiciones. Diario Oficial 46015 de agosto 29 de 2005. Disponible en: http://www.alcaldiabogota.gov.co/sisjur/normas/Norma1.jsp?i=17417

Congreso de La República de Colombia (2006) Ley 1121 De 2006 (diciembre 29) Diario Oficial No. 46.497

Congreso de la República de Colombia (2006) Informe de ponencia para primer debate al proyecto de ley 267 de 2007. Cámara, 132 DE 2006. Disponible en: http://derepenalespecial.blogspot.com.co/2009/07/los-invito-leer-los-antecedentes.html

Congreso de la República de Colombia (2008) Ley 1200 de 2008. Por medio de la cual se adiciona el artículo 169 del Código Penal, modificado por los artículos $2^{\circ}$ de la Ley 733 de 2002 y 14 de la Ley 890 de 2004. Diario Oficial 47029 de junio 23 de 2008. Disponible en: http://www.alcaldiabogota.gov.co/sisjur/normas/Norma1.jsp?i=31024.

Congreso de la República de Colombia (2011) Ley 1436 de 2011. Por medio de la cual se otorgan beneficios a las familias de las personas secuestradas con posterioridad al ejercicio de su 
Análisis Socio Jurídico del delito de secuestro en Colombia a partir de 1970

cargo. Diario Oficial 47.944 de enero 6 de 2011. Disponible en: http://www.alcaldiabogota.gov.co/sisjur/normas/Norma1.jsp?i=41189

Constitución Nacional (1991) Artículo 1.

Corte Constitucional (1992) Sentencia N C-599 de 1992. M. P. Fabio Morón Díaz.

Corte Constitucional (1992) Sentencia T 596 de 1992. M. P. Ciro Angarita Barón. Disponible en: http://www.corteconstitucional.gov.co/relatoria/1992/T-596-92.htm

Corte Constitucional (1993) Sentencia C-504 de 1993. M. P. Eduardo Cifuentes Muñoz.

Corte Constitucional (1993) Sentencia N C-127 de 1993. M. P. Alejandro Martínez Caballero.

Corte Constitucional (1993) Sentencia Nº C-207 de 1993. M. P. Carlos Gaviria Díaz.

Corte constitucional (1993) Sentencia No. C-565/93. M.P. Eduardo Cifuentes Muñoz. Disponible en: http://www.corteconstitucional.gov.co/relatoria/1993/C-565-93.htm

Corte Constitucional (1993) Sentencia c 542 de 1993. M.P. Jorge Arango Mejía. Disponible en: http://www.corteconstitucional.gov.co/relatoria/1993/c-542-93.htm

Corte Constitucional (1993) Sentencia No. C-127/93. M.P. Dr. Alejandro Martínez Caballero. Disponible en: http://www.corteconstitucional.gov.co/relatoria/1993/C-127-93.htm

Corte Constitucional (1994) Sentencia No. C-213/94. M.P. Jorge Arango Mejía. Disponible en: http://www.corteconstitucional.gov.co/relatoria/1994/C-213-94.htm

Corte Constitucional (1996) Sentencia N C-626 de 1996. M. P. José Gregorio Hernández Galindo.

Corte Constitucional (1996) Sentencia C-261 de 1996, M.P. Alejandro Martínez Caballero. Disponible en: http://www.corteconstitucional.gov.co/relatoria/1996/C-261-96.htm

Corte Constitucional (1996) Sentencia C-430 de 1996. M.P. Carlos Gaviria Díaz. Disponible en: http://www.corteconstitucional.gov.co/relatoria/1996/c-430-96.htm

Corte Constitucional (1997) Sentencia C-292 de 1997. M. P. José Gregorio Hernández Galindo. 
Análisis Socio Jurídico del delito de secuestro en Colombia a partir de 1970

Corte Constitucional (1998) Sentencia C-679 de 1998. M. P. Carlos Gaviria Díaz.

Corte Constitucional (1999) Sentencia de Constitucionalidad $N^{o}$ 272/99. P. Eduardo Cifuentes Muñoz 28 de abril de $1999 . \quad$ Disponible en: http://www.corteconstitucional.gov.co/relatoria/1999/C-272-99.htm

Corte Constitucional (1999) Sentencia de Constitucionalidad nº 272/99, 28 de Abril de 1999. P. Eduardo Cifuentes Muñoz. Disponible en: https://corte-constitucional.vlex.com.co/vid/43562588

Corte Constitucional (2001) Sentencia C-646 de 2001. M.P. Manuel José Cepeda Espinosa.

Corte Constitucional (2002) Sentencia C-806 de 2002, M.P. Clara Inés Vargas Hernández. Disponible en: http://www.corteconstitucional.gov.co/relatoria/2002/C-80602.htmhttp://www.corteconstitucional.gov.co/relatoria/2002/C-806-02.htm

Corte Constitucional (2002) Sentencia C-762/02. M.P. Rodrigo Escobar Gil Disponible en: http://www.corteconstitucional.gov.co/relatoria/2002/c-762-02.htm

Corte Constitucional (2005) Sentencia C-238/05 M.P. Jaime Araujo Rentería. 15 de marzo de 2005.

Corte Constitucional (2007) Sentencia 394 de 2007. M.P. Dr. Humberto Antonio Sierra Porto. Disponible en: http://www.corteconstitucional.gov.co/relatoria/2007/C-394-07.htm

Corte Constitucional (2010) Sentencia C-073/10 M.P. Humberto Antonio Sierra Porto. 10 de febrero De 2010.

Corte Constitucional (2010) Sentencia C-073/10. M.P. Dr. Humberto Antonio Sierra Porto. Disponible en: http://www.corteconstitucional.gov.co/RELATORIA/2010/C-073-10.htm Corte Constitucional (2010) Sentencia C 866 de 2010. M.P. Jorge Ignacio Pretelt Chaljub Disponible en: http://www.corteconstitucional.gov.co/RELATORIA/2010/C-866-10.htm 
Análisis Socio Jurídico del delito de secuestro en Colombia a partir de 1970

Corte Suprema de Justicia, (1983) Sentencia de 9 de agosto de 1983, M.P. Dr. Alfonso Reyes Echandía.

Corte Suprema de Justicia (2000) Sala De Casación Penal, M.P. Carlos Augusto Gálvez Argote, 14 de abril de 2000.

Corte Suprema de Justicia (2000) Sala De Casación Penal, Proceso Nº 14120, M. P. Jorge Aníbal Gómez Gallego, 21 de febrero de 2000.

Corte Suprema de Justicia (2004) Sala De Casación Penal, Proceso No 14538 M.P. Luis Quintero Milanés, de julio de 2004.

Corte Suprema de Justicia (2006) Sentencia 25 de mayo de 2006. Rad. 20.326. Sala de Casación Penal. P. Dr. Edgar Lombana Trujillo.

Corte Suprema de Justicia (2009) Sala de casación No 32823 del 11 de diciembre de 2009 M.P. José Leónidas Bustos Martínez, sentencia del 25 de mayo de 2006 radicado 20326.

Corte Suprema de Justicia (2009) Sala De Casación Penal, rad. 28.563 MP. Alfredo Gómez quintero, marzo de 2009.

Corte Suprema de Justicia (2010) Sala De Casación Penal Proceso N. 31407 M. P. María Del Rosario González De Lemos Aprobado Acta No. 267. Bogotá D.C., agosto 25 de 2010.

Corte Suprema de Justicia (2011) Sala De Casación Penal, Proceso n ${ }^{\circ} 36603$. M. P. Fernando Alberto Castro Caballero, 6 de julio de 2011

Corte Suprema de Justicia (2012) Sala De Casación Penal M. P. Luis Guillermo Salazar Otero, septiembre veintiséis de 2012. 
Análisis Socio Jurídico del delito de secuestro en Colombia a partir de 1970

Corte Suprema de Justicia (2013) Sala de casación penal. Proceso No 39257, M.P. Eugenio Fernández Carlier, 16 de octubre de 2013.

Corte Suprema de Justicia (2013) Sala de Casación Penal. M.P. José Leónidas Bustos Martínez. 27 de febrero de 2013.

Corte Constitucional (2016) Sentencia C-328 de 2016. M.P. Gloria Stella Ortiz Delgado. Disponible en: http://www.corteconstitucional.gov.co/relatoria/2016/c-328-16.htm

Corte Suprema de Justicia (2016) Sentencia Sp16905-2016 de 23 De Noviembre de 2016. Ponente Castro Caballero, Fernando Alberto. Disponible en: http://legal.legis.com.co/document?obra=jurcol\&document=jurcol_f8b5afcc4e3b4b46adc 740177881034a

Creus, C. (1998) Derecho Penal parte especial Tomo i 6 edición, editorial Astrea.

Chato. P (2016) Uruguay: el éxito del MLN-T y la reivindicación del pasado guerrillero. Disponible en: https://colombiaplural.com/uruguay-exito-del-mln-t-la-reivindicacion-delpasado-guerrillero/

DANE (2017) Encuesta de convivencia y seguridad ciudadana. Disponible en: https://www.dane.gov.co/index.php/estadisticas-por-tema/seguridad-y-defensa/encuestade-convivencia-y-seguridad-ciudadana-ecsc

De Rivacoba, M. (1993) Función y aplicación de la pena. Disponible en: https://sanasideas.files.wordpress.com/2015/08/rivacoba-funcion-y-aplicacion-de-lapena.pdf.

Departamento Nacional de Planeación (2013) Cifras de violencia secuestro extorsivo. Dirección de justicia y seguridad. República de Colombia. Disponible en: http://www.acnur.org/fileadmin/news_imported_files/COI_731.pdf?view=1 
Análisis Socio Jurídico del delito de secuestro en Colombia a partir de 1970

Díaz de León, M.A. (1989) Secuestro. Derecho procesal penal. Tomo II. Porrúa México D.F.

Diccionario de Ciencias Jurídicas, Políticas y Sociales (2016) Definición de secuestro. Disponible en:

https://conf.unog.ch/tradfraweb/Traduction/Traduction_docs\%20generaux/Diccionario\% 20de $\% 20$ Ciencias $\% 20 J u r i d i c a s \% 20$ Politicas $\% 20 y \% 20$ Sociales $\% 20$ -

\%20Manuel\%200ssorio.pdf

Diccionario Jurídico Cabanellas (2016) Definición de secuestro. Disponible en: https://sites.google.com/site/megalexec/diccionario-juridico/diccionario-juridicocabanellas/-s

Diccionario Real Academia Española (2016) Definición de secuestro. Disponible en: http://dle.rae.es/?id=XPzxQ8

Dirección General de Sanidad Militar. (2010) Manual de procedimientos del personal secuestrado, desaparecido, liberado o rescatado de las fuerzas militares de Colombia. Bogotá. Disponible en: www.sanidadfuerzasmilitares.mil.co/?idcategoria=4797\&download=Y

Donna, E.A. (2001) Derecho Penal. Parte ESPECIAL. Tommo II -B Rubinzal - Culzoni Editores Buenos Aires.

Echandía, C. (2004) “Evolución reciente de la geografía del conflicto armado colombiano”, en MONTAÑEZ, Gustavo (coord.) Dimensiones territoriales de la guerra y la paz, Cap. 3 El conflicto armado colombiano y su expresión territorial: presencia de los actores. Universidad Nacional de Colombia, Red de Estudios de Espacio y Territorio - RET, Bogotá.

Eju (2016) Las FARC piden perdón por daño causado por los secuestros. Disponible en: http://eju.tv/2016/09/las-farc-piden-perdon-por-dano-causado-por-los-secuestros/ 
Análisis Socio Jurídico del delito de secuestro en Colombia a partir de 1970

El Colombiano (2012) Cronología de liberaciones de secuestrados. Disponible en: http://www.elcolombiano.com/historico/farc_cronologia_de_liberaciones_de_secuestrado s-LBEC_176049

El Colombiano (2013) Solo el 24,5\% denuncia cuando es víctima de un delito: Dane. Disponible en:

http://www.elcolombiano.com/historico/solo_el_245_denuncia_cuando_es_victima_de_u n_delito_dane-OCEC_256769

El Espectador (2009) Cronología de los secuestros perpetrados por el grupo de las Farc. Disponible en: https://www.elespectador.com/noticias/judicial/articulo178770cronologia-de-los-secuestros-perpetrados-el-grupo-de-farc

El Espectador (2014) El secuestro, 'el palo en la rueda' de los otros procesos de paz. Disponible en: http://www.elespectador.com/noticias/judicial/el-secuestro-el-palo-rueda-de-losotros-procesos-de-paz-articulo-528027

El Espectador (2016) Las Farc y el Secuestro. Disponible en: https://colombia2020.elespectador.com/justicia/las-farc-y-el-secuestro

El Mundo (2016) Cronología de una década de secuestros aviones. Disponible en: http://www.elmundo.es/internacional/2016/03/29/56fa337c268e3e7b1e8b45bc.html

El Observador (2015) Secuestro, Un gran problema de América Latina. Disponible en: http://www.elobservador.com.uy/secuestros-un-gran-problema-america-latina-n654188.

El País (2008) Reportaje: Vidas Al Límite. “El infierno según Ingrid” Juan José Millás Diario El País España. Disponible en: http://elpais.com/diario/2008/10/12/eps/1223792810_850215.html 
Análisis Socio Jurídico del delito de secuestro en Colombia a partir de 1970

El País (2011) El ELN 'renace’ por el narcotráfico en Cauca y Nariño. Disponible en: http://www.elpais.com.co/judicial/el-eln-renace-por-el-narcotrafico-en-cauca-ynarino.html

El Pais.com (2011) La pataleta que cambio a Colombia. Disponible en: http://www.elpais.com.co/colombia/la-papeleta-que-cambio-a.html

El Tiempo (1993) 34.5 Ha Disminuido El Secuestro En 1993: Dijin. Disponible en: http://www.eltiempo.com/archivo/documento/MAM-223031

El Tiempo (1996) El país que queremos. Disponible en: http://www.eltiempo.com/archivo/documento/MAM-601529

El Tiempo (2000) Secuestro Masivo en Cali. Disponible en: http://www.eltiempo.com/archivo/documento/MAM-1255146

El Tiempo (2000) Las Rutas del Secuestro. http://m.eltiempo.com/archivo/documento/MAM1270852

El Tiempo (2004) Uribe No Acepta Propuesta de Farc. Disponible en: http://www.eltiempo.com/archivo/documento/MAM-1527610

El Tiempo (2008) La marcha del 4 de febrero contra las Farc nació como un foro en Internet y ya está en 163 ciudades. Disponible en: http://www.eltiempo.com/archivo/documento/CMS3941050

El Tiempo (2009) La zona de distensión paso a paso. Disponible en: http://www.eltiempo.com/archivo/documento/MAM-684002

El Tiempo (2013) El secuestro es como estar perdido en medio del mar. Disponible en: http://webcache.googleusercontent.com/search?q=cache:RSUWbaAzDAQJ:190.85.246.4 0/altus/entrevista-general-mendieta.htm $+\& \mathrm{~cd}=1 \& \mathrm{hl}=\mathrm{es} \& \mathrm{ct}=\mathrm{clnk} \& \mathrm{gl}=\mathrm{co}$ 
Análisis Socio Jurídico del delito de secuestro en Colombia a partir de 1970

El Tiempo (2013) Todavía sueño que soy secuestrado por las Farc: Marc Gonsalves. Disponible en: http://www.eltiempo.com/archivo/documento/CMS-12908153

El Tiempo (2016) Los secuestros en Colombia se redujeron un 92\% desde el 2000. Disponible en: http://www.eltiempo.com/amp/justicia/cortes/cifras-de-secuestros-en-colombia-en-el2016-42728.

El Tiempo (2016) Las Farc pidieron perdón por masacre de diputados del Valle. Disponible en: http://www.eltiempo.com/politica/proceso-de-paz/farc-piden-perdon-en-cali-pormasacre-de-diputados-38856

El Tiempo ¿Cómo reducir la criminalidad? Disponible en: http://www.eltiempo.com/opinion/columnistas/jose-fernando-florez/como-reducir-lacriminalidad-jose-fernando-florez-columnista-el-tiempo-53119

El Tiempo (2017) El populismo punitivo es una tendencia errada en todo el mundo. Disponible en: http://www.eltiempo.com/justicia/cortes/entrevista-a-claus-roxin-sobre-el-proceso-depaz-en-colombia-68588

EL Tiempo (2017) Cifras del secuestro en Colombia para el 2017. Disponible en: http://www.eltiempo.com/justicia/investigacion/cifras-del-secuestro-en-colombia-para-el2017-167252.

Elster, J. (2004) Los secuestros en las guerras civiles. Documento preparado para el taller sobre técnicas de violencia Oslo. Disponible en: https://seminariopoliticaysociedad.files.wordpress.com/2009/09/5-1.pdf

Enciclopedia de la Ley de Duhaime (2016) Definición de secuestro. Disponible en: http://www.duhaime.org/LegalDictionary.aspx 
Análisis Socio Jurídico del delito de secuestro en Colombia a partir de 1970

Encuesta Nacional de Victimización - ENVIPE (2015) Percepciones sobre seguridad pública. Disponible

en: http://www.inegi.org.mx/est/contenidos/proyectos/encuestas/hogares/regulares/envipe/en vipe2015/doc/envipe2015_presentacion_nacional.pdf

Esguerra, L. (2011) Instintos de libertad. Secuestro en América Latina. Historias e imágenes de cautiverio. Investigación para la conferencia subregional del CHDS en Santiago de Chile. Colombia: País Libre

Estatuto de Roma de la Corte Penal Internacional (2002) Disponible en: http://www.un.org/spanish/law/icc/statute/spanish/rome_statute(s).pdf

Fiscalía General de la nación (2018) Caen testaferros de la antigua guerrilla de las Farc, con red de 60 supermercados $y$ otros bienes. Disponible en: https://www.fiscalia.gov.co/colombia/extincion-de-dominio/caen-testaferros-de-laantigua-guerrilla-de-las-farc-con-red-de-60-supermercados-y-otros-bienes/

Fuerzas Militares de Colombia (2015) Disponible en: http://www.cgfm.mil.co/wpcontent/uploads/2017/05/37-LAS-FUERZAS-2015.pdf

Gacetas del Congreso (2000) 380 del 21 de septiembre de 2000, 469 del 23 de noviembre de 2000, 226 del 18 de mayo de 2001, 380 del 13 de agosto de 2001 y 628 del 7 de diciembre de 2001

García-Pablos (1988) Régimen Abierto Y Ejecución Penal (Revista Estudios Penitenciarios NUM 2401988

García-Pablos De Molina (1989) A. La aportación de la criminología. Universidad Complutense, Madrid. Número 3. 79-94 San Sebastián. 
Análisis Socio Jurídico del delito de secuestro en Colombia a partir de 1970

García, P. (1996) Sobre el principio de intervención mínima del Derecho penal como límite del "Ius Puniendi”. En: González Rus (Coord.). Estudios Penales y Jurídicos. Homenaje al Prof. Dr. Enrique Casas Barquero. Córdoba.

Grupos Armados Posdesmovilización (2006 - 2015) Trayectorias, rupturas y continuidades informe del centro nacional de memoria histórica

Hernández, A. (2003) Convocatorias al Pueblo en Colombia

El referendo de 2003 si tiene antecedentes. Disponible en: http://www.banrepcultural.org/blaavirtual/revistas/credencial/marzo2003/convocatorias.h tm

Hernández, O. (2015) Estadísticas de secuestro en Colombia enero a diciembre de 2014 boletín ágora consultorías. Disponible en: www.google.com.co/search?rlz=1C1CAFA_enCO652CO652\&biw=1600\&bih=769\&tb $\mathrm{m}=\mathrm{isch} \& \mathrm{sa}=1 \& \mathrm{ei}=\mathrm{EMzHWo}-$ NJYmazwK95ojwCg\&q=SECUESTROS++ELN+ESTADISTICAS\&oq=SECUESTROS ++ELN+ESTADISTICAS\&gs_l=psy-

ab.3..0i8i13i30k1.15927.23664.0.23786.28.25.2.0.0.0.308.3404.0j12j5j2.19.0...0...1c.1.6 4.psy-ab..9.14.2196...0i7i30k1j0i7i5i30k1j0i24k1.0.9riTdFM-d_I\#imgrc=nXOLVcyCbA0SM:

Historia Constitución política de Colombia (2011) Historia de la constitución de 1991. Disponible en: http://www.constitucioncolombia.com/historia.php

IKV PAX (2016) El secuestro un negocio explosivo. Disponible en: http://paxencolombia.org/wpcontent/uploads/2016/01/El-secuestro-es-un-negocio-explosivo.pdf 
Análisis Socio Jurídico del delito de secuestro en Colombia a partir de 1970

INDEPAZ (2009) Del Mandato del 97 Al 2007. Disponible en: http://www.indepaz.org.co/1254/del-mandato-del-97-al-2007/

Infolibre (2016) Un informe señala que 54 periodistas se encuentran secuestrados en el mundo, tres de ellos españoles. Disponible http://www.infolibre.es/noticias/medios/2016/02/03/un_informe_senala_que_periodistas_ encuentran_secuestrados_cierre_2015_44256_1027.html

Información (2013) La severidad de las penas no reduce los delitos y sí la certeza de que te van a pillar. Disponible en: http://www.diarioinformacion.com/elche/2013/09/15/severidadpenas-reduce-delitos-certeza/1415402.html

Instituto Nacional de Estadística y geografía (2012) Delitos contra las personas. Disponible en: http://www3.inegi.org.mx/sistemas/clasificaciones/delitos.aspx

Jakobs G. (1997) Derecho penal, parte general. Fundamentos y teoría de la imputación. $2^{\mathrm{a}}$ Ed. Corregida. Trad. De Joaquín Cuello Contreras y José Luis Serrano González de Murillo. Marcial Pons Editores, Madrid, 1997.

Jescheck, H. (1993) Tratado de Derecho Penal. Parte General, trad. Manzanares Samaniego, Granada, 1993.

Jiménez, R. e Islas, O.O. (2002) El secuestro Problemas sociales y jurídicos. Universidad Nacional Autónoma De México.

La Otra Cara (2017) Romaña, autor de “Las Pescas Milagrosas”, el secuestrador más grande de las Farc. Disponible en: https://laotracara.co/destacados/romana-autor-de-las-pescasmilagrosas-el-secuestrador-mas-grande-de-las-farc/

La silla vacía (2012) De lo que viven las Farc sin el secuestro. Disponible en: http://lasillavacia.com/historia/de-lo-que-viven-las-farc-sin-el-secuestro-31683 
Análisis Socio Jurídico del delito de secuestro en Colombia a partir de 1970

LAUD Universidad Distrital Francisco José de Caldas (2016) “El incremento de penas no genera nada positivo" Francisco Bernate. Disponible en: http://laud.udistrital.edu.co/noticias/\%E2\%80\%9Cel-incremento-de-penas-no-generanada-positivo\%E2\%80\%9D-francisco-bernate.

Legislación Penal Colombiana (2000) Ley 599 Código Penal. Disponible en: https://www.iberred.org/sites/default/files/codigo-penal-de-colombia.pdf

Lemaitre, J. (2011) “Control Social y seguridad ciudadana”. En: Iturralde, Manuel y Ariza Higuera, Libardo. Los Muros de la Infamia: Prisiones en Colombia y América Latina. Bogotá, Colombia. Ediciones Uniandes. Colección de Estudios CIJUS.

Lors Rue 89 (2008) Entrevista con el ex rehén de las Farc, Luis Eladio Pérez por Angélica Pérez. Disponible en: http://tempsreel.nouvelobs.com/rue89/rue89calle89/20080330.RUE3611/entrevista-con-el-ex-rehen-de-las-farc-luis-eladio-perez.html Lozano, M. (1968) Derecho penal mexicano. Porrúa, México D.F.

Martín-Baró, I. (1989) La violencia política y la guerra como causas del trauma psicosocial en El Salvador. Revista de psicología de El Salvador.

Martín-Baró, I. (1990) Psicología Social De La Guerra: Trauma Y Terapia Selección e Introducción de 1990. UCA EDITORES San Salvador, El Salvador.

Martiñón, G. (2008) El delito de secuestro. Universidad de Granada.

Medina-Mora, M., Borges, G., Lara C., Ramos L., Zambrano, J. y Fleiz, C. (2005) Prevalencia de sucesos violentos y de trastornos por estrés postraumáticos en la población mexicana. Salud Pública de México. 47 (001), 8-22. 
Análisis Socio Jurídico del delito de secuestro en Colombia a partir de 1970

Meluk, E. (1.998) El Secuestro una Muerte Suspendida: Su impacto Psicológico. Santafé de Bogotá: Ediciones Uniandes.

Mercopress (2014) Cocaína y minería ilegal, 'principales fuentes de financiamiento' de la FARC. Disponible en: http://es.mercopress.com/2014/04/08/cocaina-y-mineria-ilegal-principalesfuentes-de-financiamiento-de-la-farc

Ministerio de Justicia (Decreto 1038 de 1984) Por el cual se declara turbado el orden público y en estado de sitio todo el territorio de la República. Disponible en: https://www.unodc.org/doc/enl/1985-69-S.pdf

Ministerio de Justicia (Decreto 1336 de 1990) Por el cual se toman medidas encaminadas al restablecimiento del orden público. Disponible en: http://www.suinjuriscol.gov.co/viewDocument.asp?id=1738886\#ver_1738891

Ministerio de Justicia (Decreto 180 de 1988) Por el cual se complementa algunas normas del Código Penal y se dictan otras disposiciones conducentes al restablecimiento del orden público. Disponible en: http://www.suin-juriscol.gov.co/viewDocument.asp?id=1040981

Ministerio de Justicia (Decreto 1988 de 1971) Por el cual se dictan unas medidas relacionadas con la conservación del orden público. Disponible http://www.suinjuriscol.gov.co/viewDocument.asp?id=1381776\#ver_1381783

Ministerio de Justicia (Decreto 261 de 1988) Por la cual se modifican los artículos 29 del Decreto 180 de 1988, $2^{\circ}$ y 12 del Decreto 181 de 1988. Disponible en: http://www.suinjuriscol.gov.co/viewDocument.asp?id=1059204

Ministerio de Justicia (Decreto 2790 de 1990) Por el cual se dicta el Estatuto para la Defensa de la Justicia, integrando en una sola jurisdicción los Jueces de Orden Público y los Especializados, creando mecanismos jurídicos para su protección y la de los demás 
Análisis Socio Jurídico del delito de secuestro en Colombia a partir de 1970

intervinientes en los procesos penales de su competencia, organizando la Subdirección Nacional y las Direcciones Seccionales de Orden Público para darles el apoyo operativo y necesario para el cumplimiento de sus funciones y robusteciendo los organismos auxiliares de la justicia. Disponible en: http://suinjuriscol.gov.co/viewDocument.asp?id=1490814

Ministerio de Justicia (Ley 95 de 1936) Sistema Único de Información Normativa. Diario Oficial. Año Lxxii. N. 23316. 24, Octubre, 1936. Disponible en: http://www.suinjuriscol.gov.co/viewDocument.asp?id=1791348

Ministerio de Justicia (2013) Llegó la hora de evaluar la efectividad del Sistema Penal Acusatorio y despenalizar la mente: Ministro de Justicia. Disponible en: http://www.minjusticia.gov.co/Noticias/TabId/157/ArtMID/1271/ArticleID/497/\%E2\%8 0\%9CLleg\%C3\%B3-la-hora-de-evaluar-la-efectividad-del-Sistema-Penal-Acusatorio-ydespenalizar-la-mente\%E2\%80\%9D-Ministro-de-Justicia.aspx

Ministerio de Justicia (2017) Política Criminal del Estado Colombiano. Disponible en: http://www.politicacriminal.gov.co/Portals/0/documento/politica\%20criminal\%20(1).pdf ?ver=2017-03-09-180338-790

Molina B.M., Agudelo, M.E., Ríos, A., Builes, M.V., Ospina, A., Arroyave, R., López, O.L., Vásquez, M., Navia, C.E. (2003) El secuestro: su repercusión en las creencias y en la estructura de relaciones en un grupo de familias antioqueñas. Revista colombiana de Psiquiatría. ISSN 0034-7450 vol.32 no.1. Disponible en: http://www.scielo.org.co/scielo.php?script=sci_arttext\&pid=S0034-74502003000100003 Moreno, M. (2010) "La política criminal legislativa"; Moreno, Moisés (Coord.), Orientaciones de la política criminal legislativa. Instituto Nacional de Ciencias Penales, México. 
Análisis Socio Jurídico del delito de secuestro en Colombia a partir de 1970

Muñoz, F. (1979) Resocialización del delincuente análisis y crítica de un mito. Doctrina Penal, Madrid.

Muñoz, F. (1985) Derecho penal y control social. Jerez, Fundación Universitaria de Jerez.

Muñoz, F. (2015) Derecho penal. Parte especial, 20 edición. Editorial tirant to Blanch Valencia.

Naciones Unidas (1981) Asamblea general. Trigésimo sexto periodo de sesiones. Disponible en: http://www.un.org/es/comun/docs/?symbol=A/RES/36/21

Naciones Unidas (2013) Declaración sobre los principios fundamentales de justicia para las víctimas de delitos y del abuso de poder Disponible en: http://legal.un.org/avl/pdf/ha/dbpjvcap/dbpjvcap_ph_s.pdf

Navia, C.E. y Ossa, Marcela (2000) Sometimiento y Libertad: Manejo Psicológico y Familiar del Secuestro. Bogotá: País Libre y Colciencias.

Navia, C.E. (2001) Los efectos del secuestro en la sociedad. Bogotá: País Libre y Colciencias. Disponible en: http://www.semana.com/opinion/articulo/los-efectos-del-secuestrosociedad/44737-3

Navia, C.E. y Ossa, M. (2001) El secuestro, un trauma psicosocial. Revista estudios sociales universidad de los Andes. Disponible https://res.uniandes.edu.co/view.php/203/index.php?id=203

Noticias RCN (2017) ELN defendió el secuestro como un "mecanismo de financiación". Disponible en: https://www.noticiasrcn.com/nacional-dialogos-paz/eln-defendio-elsecuestro-un-mecanismo-financiacion.

Notimérica (2011) Santos confiesa que estuvo tentado a suspender las liberaciones de los secuestrados por las FARC. Disponible en: http://www.notimerica.com/politica/noticia- 
Análisis Socio Jurídico del delito de secuestro en Colombia a partir de 1970

colombia-santos-confiesa-estuvo-tentado-suspender-liberaciones-secuestrados-farc20110210190723.html

Núñez, R. (1951) Delitos contra la propiedad. Bibliográfica Argentina, Buenos Aires.

Nuñéz, R. (2008) Manual de Derecho Penal. Tercera edición actualizada por Victor Félix Reinaldi. Ed. Lerner.

NYA (2015) Global Kidnap for Ransom Update. Crisis Prevention y Response. Disponible en: http://www.nyainternational.com/sites/default/files/no-index/NYA-Global-Kidnap-forRansom-Update-April-2015-362.pdf

OAS (1969) Convención Americana Sobre Derechos Humanos Suscrita En La Conferencia Especializada Interamericana Sobre Derechos Humanos (B-32) San José, Costa Rica 7 al 22 de noviembre de 1969. Disponible en: https://www.oas.org/dil/esp/tratados_b32_convencion_americana_sobre_derechos_humanos.htm

Organización de Estados Americanos (2016) Observatorio, definición de secuestro. Disponible en: http://www.oas.org/dsp/Observatorio/database/glossarydetails.aspx ?lang=en\&type=2\&id $=194$

Observatorio Nacional Ciudadano (2016) Reporte mensual de delitos de alto impacto, mayo 2016. Disponible en: http://onc.org.mx/

Oficina de las Naciones Unidas contra la droga y el delito (2006) Manual de lucha contra el secuestro. Viena Naciones Unidas. Disponible en: https://www.unodc.org/documents/lpobrazil/Topics_crime/Publicacoes/Manual_antisequestro_ONU.pdf 
Análisis Socio Jurídico del delito de secuestro en Colombia a partir de 1970

Organización de Estados Americanos - Secretaría General (Febrero de 2007) Octavo informe trimestral del Secretario General al Consejo Permanente sobre la Misión de Apoyo al Proceso de Paz en Colombia (MAPP/OEA). Disponible en: www.mapp-oea.org.

Órnelas, J. (2002) El secuestro: Uno de los males sociales del mexicano. Problemas sociales y jurídicos. Disponible en: http://biblio.juridicas.unam.mx/libros/1/244/2.pdf

Páez, C.M. (2010) La Esclavitud Sexual En La Legislación Penal Colombiana. Interpretación A Través De Otras Fuentes Normativas $Y$ Jurisprudenciales. Disponible en: https://dialnet.unirioja.es/descarga/articulo/5978985.pdf

País Libre (1995) Crónica de Un Atroz Delito. Santafé de Bogotá: Ediciones Armor International. País libre (2011) Fenomenología del secuestro en Colombia estadísticas y principales obstáculos jurídicos y emocionales en las víctimas la experiencia de los dos últimos años. Bogotá, D.C., Colombia. Disponible en: http://www.ideaspaz.org/tools/download/52139

Palacios, G. (2014) La cárcel desde adentro. Entre la reinserción social del semejante y la anulación del enemigo. Porrúa, México.

Peña, A. (2008) Derecho Penal Parte Especial TOMO I IDEMSA Lima-Perú.

Pabón, P.A. (2015) Código Penal Esquemático, cuarta edición.

Parra, A.M. (2013) Estado de Excepción en Colombia: Análisis del Periodo Presidencial 20022006. Disponible en: http://repository.urosario.edu.co/bitstream/handle/10336/4340/10190345912013.pdf?sequence $=1$ 
Análisis Socio Jurídico del delito de secuestro en Colombia a partir de 1970

Pax en Colombia (2016) El secuestro es un negocio explosivo. Disponible en: http://paxencolombia.org/wp-content/uploads/2016/01/El-secuestro-es-un-negocioexplosivo.pdf

Pizarro, E. (2004) Una democracia asediada: Balance y perspectivas del conflicto armado en Colombia. Grupo Editorial Norma, Bogotá.

Prodavinci (2013) ¿Qué lugar ocupa Venezuela en el ranking mundial de secuestros? Disponible en: http://prodavinci.com/2013/12/13/vivir/que-lugar-ocupa-venezuela-en-el-rankingmundial-de-secuestros/

Programa de las Naciones Unidas (2016) Informe regional de desarrollo humano 2013-2014. Seguridad Ciudadana con rostro humano: diagnóstico y propuestas para América Latina. Disponible en: $\quad$ http://www.undp.org/content/dam/rblac/img/IDH/IDHAL\%20Informe\%20completo.pdf

Programa de Naciones Unidas para el Desarrollo (2014) Informe para el Desarrollo Humano. Disponible en: http://hdr.undp.org/sites/default/files/hdr14-summary-es.pdf)

Quintero, C., Rodríguez, L. y Vera, C. (1.995) Estudio de las Funciones del Yo en la Elaboración Psíquica con Personas que han Vivido un Secuestro. Tesis de Grado, Pontificia Universidad Javeriana, Santafé de Bogotá.

Radio Santa Fé (2016) Farc campos de concentración. Disponible en: https://www.google.com.co/search?q=campos+concentracion+farc\&source=lnms\&tbm=i sch\&sa=X\&ved=0ahUKEwjQ6f7k9qDaAhXCq1kKHS2UBBEQ_AUICigB\&biw=1326 \&bih=608\#imgrc $=$ KzXzFNC-5IPtHM 
Análisis Socio Jurídico del delito de secuestro en Colombia a partir de 1970

Razonpublica (2009) El fin del secuestro político: ¿por qué las Farc fracasaron en su intento?

Disponible en: https://www.razonpublica.com/index.php/conflicto-drogas-y-paz-temas30/57-el-fin-del-secuestro-polco-ipor-quas-farc-fracasaron-en-su-intento.html

Reed M, (2012) El Camino Irreflexivo de la Cárcel en Colombia: Un Cuento de Delirios Y Despelotes. Disponible en: https://www.wilsoncenter.org/sites/default/files/presentation\%20Michael\%20Reed_0.pdf

Redjurista (Decreto - Ley 100 De 1980) Por el cual se expide el nuevo Código Penal. Diario Oficial No. 35.461 de 20 de febrero de 1980. Disponible en: www.redjurista.com/Documents/codigo_penal_1980_(derogado)__decreto_100_de_1980.aspx\#/

Revista Actualidad Laboral (2006) La protección laboral a las víctimas del secuestro: una nueva ley y un viejo debate. Revista $\mathrm{N}^{\circ} 134$ Mar.-Abr. 2006.

Revista Semana (2005) Las cuentas de las Farc. Disponible en: http://www.semana.com/nacion/articulo/las-cuentas-farc/70582-3

Revista Semana (2007) Clamor por los secuestrados. Disponible en: http://www.semana.com/nacion/articulo/clamor-secuestrados/83899-3

Revista Semana (2012) Farc anuncian que abandonan el secuestro extorsivo; liberarán 10 uniformados. Disponible en: http://www.semana.com/amp/farc-anuncian-que-abandonanel-secuestro-extorsivo-liberaran-10-uniformados/254058

Rfi español (2007) Uribe cancela mediación de Chávez. Disponible en: http://www1.rfi.fr/actues/articles/095/article_6149.asp

RISK MAP (2016) Control Risk. Disponible en: https://riskmap.controlrisks.com/ 
Análisis Socio Jurídico del delito de secuestro en Colombia a partir de 1970

Rodríguez, A. y Camacho (2000). Cambios en la identidad de los ex secuestrados. Tesis facultad de Psicología Pontificia Universidad Javeriana

Roxin, C. (1997) Derecho Penal. Parte General. Trad. Diego - Manuel Luzón Peña y otros. T.I., Civitas, Madrid, 1997, reimpresión 2003.

Roxin, C. (2010) Derecho penal parte general tomo I editorial Thomson Civitas

Rubio M. (2003) Del rapto a la pesca milagrosa: breve historia del secuestro en Colombia. Bogotá, CEDE, Universidad de los Andes. Disponible en: https://core.ac.uk/download/pdf/6517039.pdf

Rubio, (2007) Del Rapto A La Pesca Milagrosa. Breve Historia Del Secuestro En Colombia. Editorial Externado De Colombia.

Salmón, E. (2004) Introducción al Derecho Internacional Humanitario. Instituto de Democracia y Derechos Humanos de la Pontificia Universidad Católica del Perú y Comité Internacional de la Cruz Roja. Fondo Editorial de la Pontificia Universidad Católica del Perú, 2004.

Samayoa, J. (1987) Guerra y deshumanización: una perspectiva psicosocial. Estudios Centroamericanos.

Sanz, N. (2000) Alternativas a la pena privativa de libertad, Editorial Colex, Madrid, 2000, y en Muñoz Conde, Francisco, Resocialización del delincuente análisis y crítica de un mito, Doctrina Penal, Madrid, 1979.

Silva, O.M. (2007) Secuestro en Colombia Evolución del Delito en los Últimos 11 Años. Revista Criminalidad, Seguridad Rural Y Urbana. Policía Nacional. Disponible en: https://www.policia.gov.co/file/6590/download?token=t3vFnww6

Soler, S. (1992) Derecho Penal Argentino. Actualizado por Guillermo Fierro. Editorial Tea. 
Análisis Socio Jurídico del delito de secuestro en Colombia a partir de 1970

Sthepen, F. (2012) Violentología: un manual del conflicto colombiano. 1 edición. Disponible en: http://www.centrodememoriahistorica.gov.co/descargas/informes2013/secuestro/sociedad -secuestrada.pdf

Twitter Álvaro Uribe Vélez (2014) Soldados en campos de concentración de FARC. Disponible en: https://www.google.com.co/search?q=campos+concentracion+farc\&source=lnms\&tbm=i sch\&sa=X\&ved=0ahUKEwjQ6f7k9qDaAhXCq1kKHS2UBBEQ_AUICigB\&biw=1326 \&bih=608\#imgrc=yKACQDO_OK_A8M:

Universidad de los Andes (2011) Comentarios Sobre La Política Criminal En Colombia. Disponible:

https://grupodeprisiones.uniandes.edu.co/images/stories/relatorias/PRISIONESOCT2011/PRODUCTOSRELATORIA/politicacriminal.pdf

Urribarres, R. (2000) La aviación civil cubana: Secuestros de aviones. Disponible en: http://www.urrib2000.narod.ru/Civ8.html

Velásquez, F. (2010) Manual de derecho penal. Parte general, cuarta edición 2010.

Verdad abierta (2011) Muerte a secuestradores MÁS: Los orígenes del paramilitarismo. Disponible en: http://www.verdadabierta.com/victimarios/244-la-historia/auc/3556muerte-a-secuestradores-mas-los-origenes-del-paramilitarismo

Verdad Abierta (2013) Lo que hizo las Farc en Cundinamarca. Disponible: http://www.verdadabierta.com/la-historia/4415-los-crimenes-de-las-farc-encundinamarca-

Vizcaino G. (2004) Secuestrados o prisioneros de guerra: visiones de un mismo conflicto armado. Colombia, Universidad Cooperativa de Colombia. 
Análisis Socio Jurídico del delito de secuestro en Colombia a partir de 1970

Waller, I. (2014) El crimen y la violencia no son inevitables. Disponible en: http://www.pensamientopenal.com.ar/system/files/2014/09/doctrina39806.pdf

Zaffaroni, R. (1996) Manual de derecho penal. Editorial Cárdenas. México.

Zaffaroni, E.R. (2009) La pena como venganza razonable. Universidad de Buenos Aires, Argentina. Disponible en: http://www.cienciaspenales.net/files/2016/07/48zaffaroni-lapena-como-venganza-razonable.pdf

Zafaronni, E.R. (2016) La pena como venganza razonable. Portal Iberoamericano de las Ciencias Penales. Universidad de Buenos Aires Argentina. Disponible en: http://www.cienciaspenales.net/files/2016/07/48zaffaroni-la-pena-como-venganzarazonable.pdf

20 minutos (2011) Las FARC anuncian liberaciones tras las masivas movilizaciones contra el secuestro. Disponible en: https://www.20minutos.es/noticia/1242660/0/farcanuncia/liberaciones-secuestrados/movilizaciones-colombia/\#xtor=AD$15 \& x t s=467263 \# x$ tor $=$ AD $-15 \& x t s=467263$

20 minutos (2016) Boko Haram ha secuestrado a 2.000 niñas y mujeres en Nigeria desde 2014, según AI. Disponible en: http://www.20minutos.es/noticia/2431159/0/boko-haram/ninasmujeres-secuestradas/informe-amnistia-internacional/\#xtor=AD$15 \& x t s=467263 \# x$ tor $=$ AD $-15 \& x t s=467263$ 